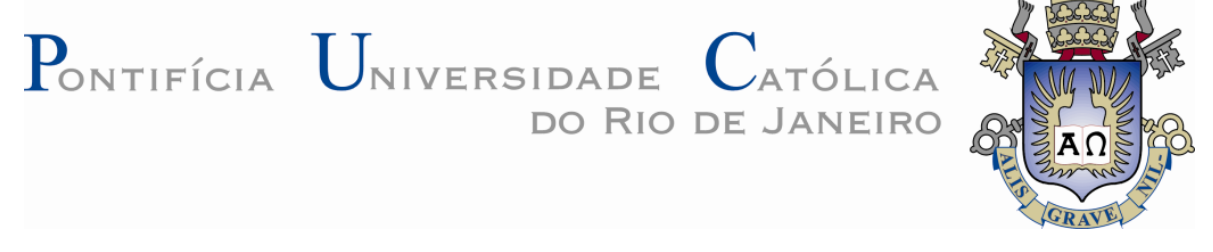

Andrew David Mendes Guedes

\title{
Estudo Experimental sobre o Impacto do Etanol em Misturas Diesel-Biodiesel-Etanol nos Motores de Ignição por Compressão
}

Dissertação apresentada ao Programa de Pós-graduação em Engenharia Mecânica da PUC-Rio como requisito parcial para obtenção do grau de Mestre em Engenharia Mecânica.

Orientador: Prof. Sergio Leal Braga Coorientador: Prof. Florian Alain Yannick Pradelle 


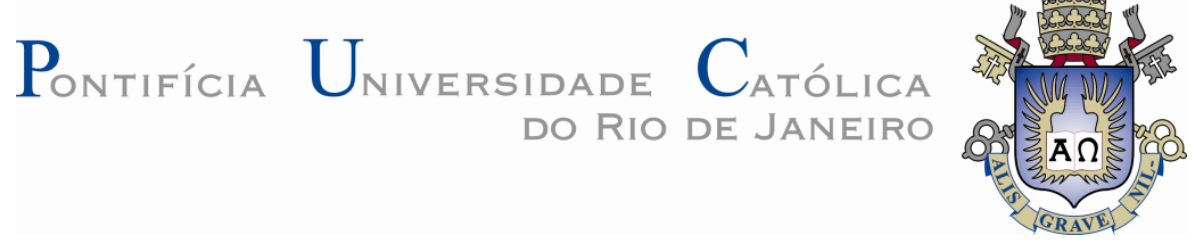

Andrew David Mendes Guedes

\title{
Estudo Experimental sobre o Impacto do Etanol em Misturas Diesel-Biodiesel-Etanol nos Motores de Ignição por Compressão
}

Dissertação apresentada como requisito parcial para a obtenção do grau de Mestre pelo Programa de Pósgraduação em Engenharia Mecânica do Centro Técnico Científico da PUC-Rio. Aprovada pela Comissão Examinadora abaixo assinada.

\author{
Prof. Sergio Leal Braga \\ Orientador \\ Departamento de Engenharia Mecânica - PUC-Rio \\ Prof. Florian Alain Yannick Pradelle \\ Coorientador \\ Departamento de Engenharia Mecânica - PUC-Rio \\ Prof. Carlos Valois Maciel Braga \\ Departamento de Engenharia Mecânica - PUC-Rio \\ Prof. José Alberto dos Reis Parise \\ Departamento de Engenharia Mecânica - PUC-Rio \\ Dr. Antonio Carlos Scardini Villela \\ Cenpes/Petrobras
}

Prof. Márcio da Silveira Carvalho

Coordenador Setorial do Centro

Técnico Cientifico - PUC-Rio

Rio de Janeiro, 12 de Abril de 2017 
Todos os direitos reservados. É proibida a reprodução total ou parcial do trabalho sem autorização da universidade, do autor e do orientador.

\section{Andrew David Mendes Guedes}

Graduou-se em Engenharia Mecânica pela Pontifícia Universidade Católica do Rio de Janeiro (PUC-Rio) em 2014. Possui experiência em simulação termo-hidráulica, tendo atuado na área de dutos. Atualmente participa de projetos de pesquisa e desenvolvimento na área de energia, no LEV/PUCRio, no setor de engenharia veicular.

Ficha Catalográfica

Guedes, Andrew David Mendes

Estudo experimental sobre o impacto do etanol em misturas diesel-biodiesel-etanol nos motores de ignição por compressão / Andrew David Mendes Guedes ; orientador: Sergio Leal Braga ; co-orientador: Florian Alain Yannick Pradelle. - 2017.

149 f. : il. color. ; $30 \mathrm{~cm}$

Dissertação (mestrado)-Pontifícia Universidade Católica do Rio de Janeiro, Departamento de Engenharia Mecânica, 2017.

Inclui bibliografia

1. Engenharia Mecânica - Teses. 2. Etanol. 3. Biodiesel. 4. Mistura ternária. 5. Motor de ignição por compressão. I. Braga, Sergio Leal. II. Pradelle, Florian Alain Yannick. III. Pontifícia Universidade Católica do Rio de Janeiro. Departamento de Engenharia Mecânica. IV. Título. 


\section{Agradecimentos}

Antes de tudo, agradeço a Deus, por Sua graça, Seu amor incomparável e incondicional, além de Seu cuidado especial com minha vida.

A minha família, por tudo que já fizeram e fazem por mim, pela disponibilidade, amor e todo suporte, seja este emocional, técnico, ou financeiro.

Ao professor e orientador do projeto Sergio Leal Braga pela ideia original do trabalho, dedicação, orientação, confiança e apoio ao longo de todo o período de mestrado.

Ao coorientador Florian Alain Yannick Pradelle por seu companheirismo, disponibilidade em ajudar, paciência e colaborações fundamentais para o desenvolvimento desta dissertação.

Aos engenheiros Fernando Zegarra e Leonardo Braga, técnicos Gilson Pradanoff e Jorge Moura, assim como ao funcionário Gerson Silvério por toda a atenção despendida e pelo suporte técnico no transcorrer do projeto.

Aos técnicos, engenheiros e demais funcionários do laboratório de Engenharia Veicular e do Instituto Tecnológico por todo auxílio e parceria.

Ao Departamento de Engenharia Mecânica e sua coordenação pela disponibilização de cursos de alto nível e orientação relacionada às formalidades ao longo do curso de pós-graduação.

Agradecimentos especiais ao PRH-ANP, órgão de fomento à pesquisa, pelo apoio financeiro sem o qual este trabalho não teria se tornado possível.

Aos amigos que de alguma forma contribuíram para a realização deste trabalho, ou simplesmente o encorajaram. 


\section{Resumo}

Guedes, Andrew David Mendes; Braga, Sergio Leal (Orientador); Pradelle, Florian Alain Yannick (Coorientador). Estudo Experimental sobre o Impacto do Etanol em Misturas Diesel-Biodiesel-Etanol nos Motores de Ignição por Compressão. Rio de Janeiro, 2017. 149p. Dissertação de Mestrado - Departamento de Engenharia Mecânica, Pontifícia Universidade Católica do Rio de Janeiro.

Há algum tempo biocombustíveis renováveis são potenciais soluções sugeridas às questões de emissão de poluentes e dependência da sociedade aos derivados fósseis. Biodiesel e etanol são combustíveis comerciais renováveis candidatos à substituição das fontes fósseis, especialmente, em motores de ignição por compressão, os quais são tipicamente mais eficientes do que aqueles de ignição por centelha. Misturas ternárias de diesel, biodiesel e etanol formam estratégias de substituição parcial do diesel aplicáveis em motores de ignição por compressão sem a necessidade de grandes adaptações. Nesta dissertação realizaram-se avaliações experimentais em um motor multi-cilíndrico de ignição por compressão (MWM 4.10 TCA), abastecido com misturas de diesel, biodiesel (até $15 \%$ em teor volumétrico) e etanol anidro (até $20 \%$ em teor volumétrico). Cada mistura ternária é composta por diferentes proporções do álcool e sempre com a concentração volumétrica de $1 \%$ de um aditivo estabilizador da mistura. Portanto, os testes associam substituições parciais do diesel por biocombustíveis a avaliações de desempenho do motor e da combustão das misturas, sob algumas condições de carga, regimes de rotação e instantes de injeção de combustível. Os testes realizados indicam que misturas com $20 \%$ em volume de concentração de etanol experimentam inícios de combustão até $4,7^{\circ} \mathrm{CA}$ mais atrasados. Porém, a busca de instantes otimizados na injeção de combustível trouxe melhorias ao desempenho do motor, permitiu conversões energéticas mais vantajosas do etanol na ignição por compressão frente à ignição por centelha, além de minimizar efeitos do etanol em retardar o início da combustão.

\section{Palavras chaves}

Etanol; Biodiesel; Mistura Ternária; Motor de Ignição por Compressão. 


\section{Abstract}

Guedes, Andrew David Mendes; Braga, Sergio Leal (Advisor); Pradelle, Florian Alain Yannick (Co-advisor). Experimental Study about Ethanol Impact in Diesel-Biodiesel-Ethanol Blends in Compression Ignition Engines. Rio de Janeiro, 2017. 149p. Dissertação de Mestrado Departamento de Engenharia Mecânica, Pontifícia Universidade Católica do Rio de Janeiro.

Renewable biofuels have been proposed for a long time as an alternative to the issues concerned to pollutants emission and also society's liability to fossil fuels. Biodiesel and ethanol are renewable commercial fuel candidates for fossil fuels substitution, especially, in compression ignition engines, which are typically more efficient than the spark ignition ones. Diesel's partial replacement, such as the substitution by ternary blends formed by diesel, biodiesel and ethanol, is a strategy applicable to compression ignition engines without the need of further modifications. In this dissertation tests were run in a multi-cylinder compression ignition engine (MWM 4.10 TCA), fueled with diesel, biodiesel (up to $15 \%$ in volumetric content) and anhydrous ethanol (up to $20 \%$ in volumetric content) blends. Each mixture should be composed by different alcohol's proportions and always containing a $1 \%$ volumetric concentration of additive in order to ensure ternary's blend stability. Therefore, tests try to ally diesel's partial replacement by biofuels with engine performance and blends' combustion assessment, under some combinations of load, engine speed and injection timing conditions. The tests performed indicate that the start of the combustion experienced up to $4.7^{\circ}$ CA postponements, when fueled with a $20 \%$ ethanol volumetric concentration blend. Still, optimized injection timing investigation brought improvements to engine performance, allowed better ethanol energetic conversions through compression ignition when compared to spark ignition and could also minimize delays caused by ethanol's presence in the beginning of the combustion.

\section{Keywords}

Ethanol; Biodiesel; Ternary Blend; Compression Ignition Engine. 


\section{Sumário}

1 Introdução 16

1.1 Contextualização 16

$\begin{array}{ll}1.2 \text { Motivações } & 17\end{array}$

1.2.1 Substituição do Petróleo e seus Derivados 17

$\begin{array}{lll}1.2 .2 \text { Emissões } & 20\end{array}$

$\begin{array}{lll}1.3 \text { Objetivo } & 24\end{array}$

1.4 Conteúdo do trabalho 25

2 Revisão Bibliográfica 26

2.1 Combustão de Ignição por Compressão - Diesel Convencional 26

2.1.1 Atraso da Ignição 30

2.1.2 Detonação 31

2.1.3 Óleo Diesel 33

2.1.4 Biodiesel 34

2.2 Etanol e os Motores de Ignição por Compressão 35

$\begin{array}{lll}2.2 .1 \text { Etanol } & 37\end{array}$

2.2.2 Injeção Dual-Fuel 39

2.2.3 Melhoradores da Autoignição 43

2.2.4 Conversão de Ciclo Diesel em Ciclo Otto ("Ottolização") 45

2.2.5 Misturas Etanol/Diesel 46

2.2.6 Misturas Etanol/Diesel com Aditivos Estabilizadores 48

2.3 Misturas Diesel/Biodiesel/Etanol (DBE) 51

2.3.1 Miscibilidade de Misturas DBE 51

2.3.2 Características da Combustão de Misturas DBE 54

2.3.3 Os Biocombustíveis Estabilizadores em Misturas Diesel/Etanol 56

3 Aparato e Procedimento Experimental 59

3.1 Motor MWM 4.10 TCA 59

3.2 Dinamômetro Elétrico de Bancada 62

$\begin{array}{lll}3.3 & \text { Sistemas de Arrefecimento } & 63\end{array}$ 
3.4 Equipamentos Complementares 64

$\begin{array}{ll}3.5 & \text { Procedimento Experimental } \\ \end{array}$

4 Fundamentação Teórica e Redução de Dados 72

4.1 Parâmetros Geométricos 72

4.2 Pressão Média Efetiva e Pressão Média Indicada 73

4.3 Potência Efetiva 74

4.4 Consumos Específicos e Consumo de Ar $\quad 75$

4.5 Razão Ar/Combustível e Razão de Equivalência 77

4.6 Eficiências 78

4.7 Relação Politrópica $\quad 81$

4.8 Aplicação da Primeira Lei da Termodinâmica 82

4.9 Atraso da Ignição 86

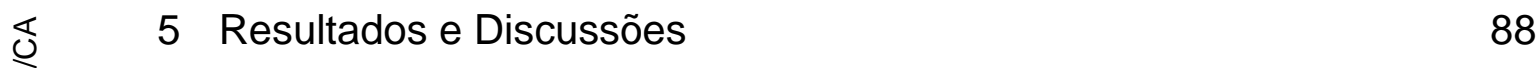

5.1 Avaliações com Avanços de Injeção Fixos 88

5.1.1 Definição das Combinações de Torque e Rotação 88

$\begin{array}{ll}\text { 5.1.2 Desempenho do Motor } & 91\end{array}$

5.1.3 Processo de Combustão com Avanços de Injeção Fixos 95

5.2 Busca por Avanços de Injeção Otimizados 101

5.3 Avaliações com Avanços de Injeção Otimizados 103

5.3.1 Desempenho com Avanços Otimizados 104

5.3.2 Processo de Combustão com Avanços Otimizados 109

6 Conclusões e Recomendações 115

6.1 Conclusões 115

6.2 Sugestões para Trabalhos Futuros 117

7 Referências Bibliográficas 118

Apêndices $\quad 135$

A. Propriedades Físico-Químicas $\quad 135$

B. Fatores de Correção da Vazão Volumétrica de Ar Úmido 136

C. Análise de Incertezas 139 
C.1 Incertezas nas Medições $\quad 139$

C.2 Propagação das Incertezas 140

Anexos 142

A. Correlação entre o Came e Deslocamento do Pistão Distribuidor 142

B. Caracterização da Amostra de Diesel Comercial (B7) 143

C. Caracterização da Amostra de Biodiesel Puro 144

D. Tabelas de Testes com Avanço de Injeção Fixo em 10,5 BTDC 145

E. Tabela de Testes da Investigação dos Avanços de Injeção 147

F. Tabelas de Testes com Otimizações para as Misturas DBE 148 


\section{Lista de Figuras}

Figura 1 - Consumo final por fonte no Brasil de 1970 até 2015 [5] 18

Figura 2 - Emissões totais em Mt de $\mathrm{CO}_{2}$ no Brasil em 2015 [5] 22

Figura 3 - Histórico de limites de emissões EPA e Euro ( $\mathrm{NO}_{x}$ e PM) 23

Figura 4 - Modelo conceitual da combustão Diesel Convencional [4] 27

Figura 5 - Evolução técnica do motor $\mathrm{Cl}$ nas últimas décadas [17] 28

Figura 6 - Desencadeamento temporal do processo CDC 29

Figura 7 - Efeitos da detonação pela curva de pressão 32

Figura 8 - Comparação de motor $\mathrm{Cl}$ movido a diesel e etanol 38

Figura 9 - Estratégia dual-fuel com "fumigação" 40

Figura 10 - Efeitos da Injeção de Diferentes Frações de Etanol 41

Figura 11 - Posicionamento da dupla injeção direta no cabeçote [54] 43

Figura 12 - Torque e potência em misturas etanol/diesel com aditivo $\quad 49$

Figura 13 - Concentrações em diagrama de fase ternário 52

Figura 14 - Diagrama de fase ternário para tipos de etanol 53

Figura 15 - Planos de temperatura para diagramas de fase ternários $\quad 54$

Figura 16 - Desenho esquemático do aparato experimental 59

Figura 17 - Motor MWM 4.10 TCA no dinamômetro de bancada $\quad 60$

Figura 18 - Desenho da bomba injetora distribuidora BOSCH VE 61

Figura 19 - Dinamômetro de bancada AVL, modelo Start 62

Figura 20 - Posicionamento dos trocadores de calor na bancada $\quad 63$

Figura 21 - Medidor de vazão laminar do consumo de ar 64

Figura 22 - Medidor de vazão Coriolis do consumo de combustível $\quad 65$

Figura 23 - llustração da medição de pressão durante os testes $\quad 66$

Figura 24 - Dimensões geométricas do conjunto cilindro-pistão 73

Figura 25 - Volume de controle com válvulas fechadas 83

Figura 26 - Exemplo de curva da terceira derivada da pressão $\quad 87$

Figura 27 - Frações alcançadas do torque máximo de B7 90

Figura 28 - Volume injetado nas condições operacionais máximas $\quad 90$

Figura 29 - Fator lambda - avanço de 10,5 BTDC 92

Figura 30 - cec - avanço de 10,5 BTDC 93 
Figura 31 - Eficiência Térmica - avanço de 10,5 BTDC 94

Figura 32 - Pressão indicada - 25\% e 50\% a 1500RPM 95

Figura 33 - Pressão indicada - 25\% e 50\% a 1800RPM 96

Figura 34 - Pressão indicada - 25\% e 50\% a 2100RPM 96

Figura 35 - Pressões máximas - avanço de 10,5 BTDC 97

Figura 36 - Liberação de calor - 25\% e 50\% 1500RPM 97

Figura 37 - Liberação de calor - 25\% e 50\% a 1800RPM 98

Figura 38 - Liberação de calor - 25\% e 50\% a 2100RPM 98

Figura 39 - B15E5 cec a 25\% e 50\% dos torques máximos de B7 102

Figura 40 - B15E10 cec a 25\% e 50\% dos torques máximos de B7 102

Figura 41 - B15E15 cec a 25\% e 50\% dos torques máximos de B7 102

Figura 42 - B15E20 cec a 25\% e 50\% dos torques máximos de B7 103

Figura 43 - Eficiência térmica - avanços otimizados 104

Figura 44 - Eficiência térmica do etanol - avanços otimizados 105

Figura 45 - Conversão energética do etanol - avanços otimizados 107

Figura 46 - Pressão - 25\% e 50\% a 1500RPM - Otimização 110

Figura 47 - Pressão - 25\% e 50\% a 1800RPM - Otimização 110

Figura 48 - Pressão - 25\% e 50\% a 2100RPM - Otimização 110

Figura 49 - Calor - 25\% e 50\% a 1500RPM - Otimização 111

Figura 50 - Calor - 25\% e 50\% a 1800RPM - Otimização 111

Figura 51 - Calor - 25\% e 50\% a 2100RPM - Otimização 111 


\section{Lista de Tabelas}

Tabela 1 - Principais impactos dos gases nocivos da combustão [11] 21

Tabela 2 - Especificações do motor MWM 4.10 TCA 60

Tabela 3 - Composições dos combustíveis em teor volumétrico $\quad 68$

Tabela 4 - Pares de torque versus rotação 69

Tabela 5 - Ângulos investigados nos processos de otimização $\quad 70$

Tabela 6 - Ângulos de injeção e ajustes na bomba $\quad 71$

Tabela 7 - Condições de referência com o combustível B7 89

Tabela 8 - Atraso da ignição - avanço de 10,5 BTDC 99

Tabela 9 - Intervalo entre CA90 e CA10 - avanço de 10,5 BTDC 101

Tabela 10 - Resumo da seleção dos avanços ótimos 103

Tabela 11 - Incertezas absolutas das eficiências térmicas do etanol 106

Tabela 12 - Conversão energética de etanol - Resultados de Villela 108

Tabela 13 - Atraso da ignição e a modificação de avanços 113

Tabela 14 - Atraso da ignição - otimização 113

Tabela 15 - Intervalo entre CA90 e CA10 - otimização 114 


\section{Lista de símbolos}

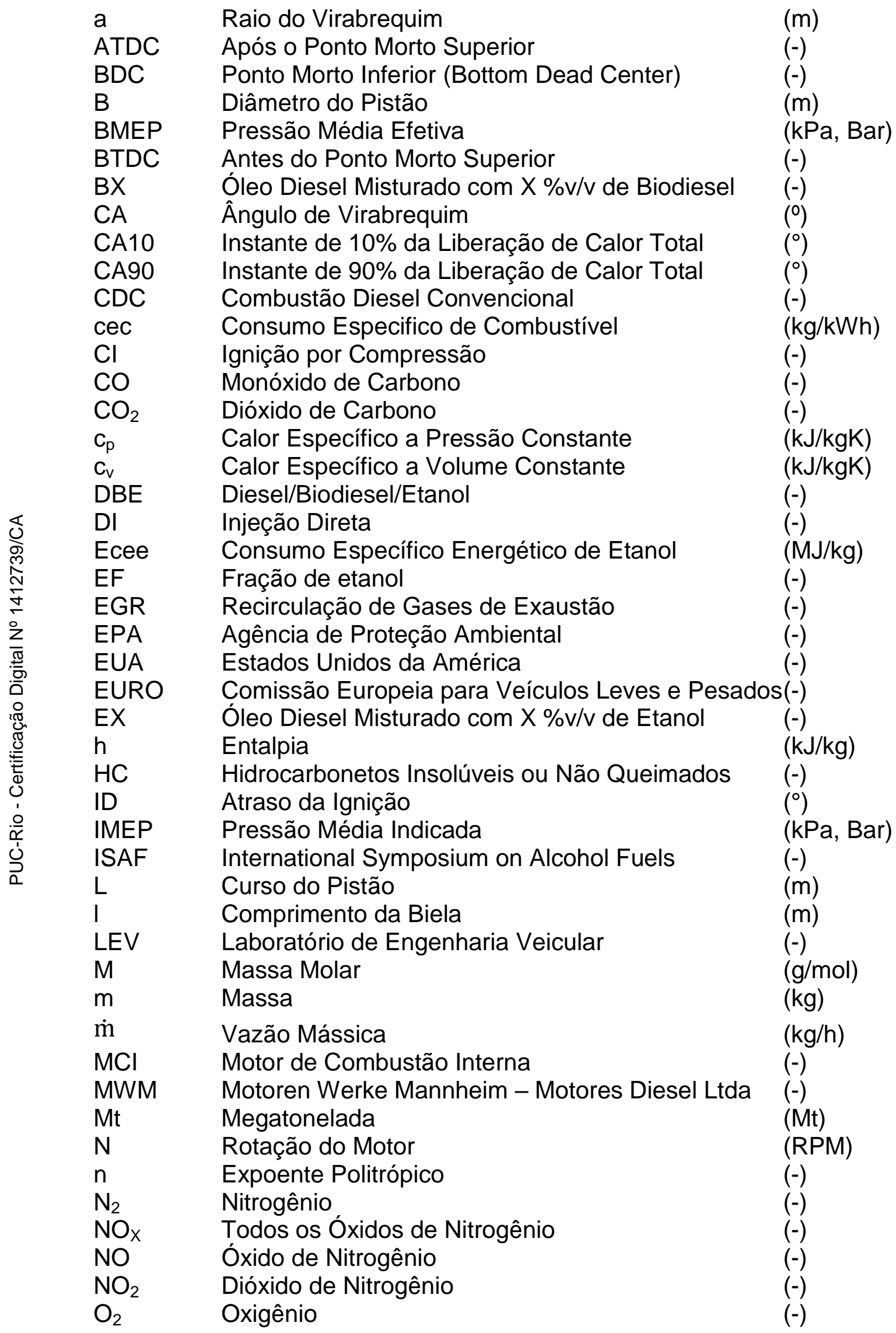




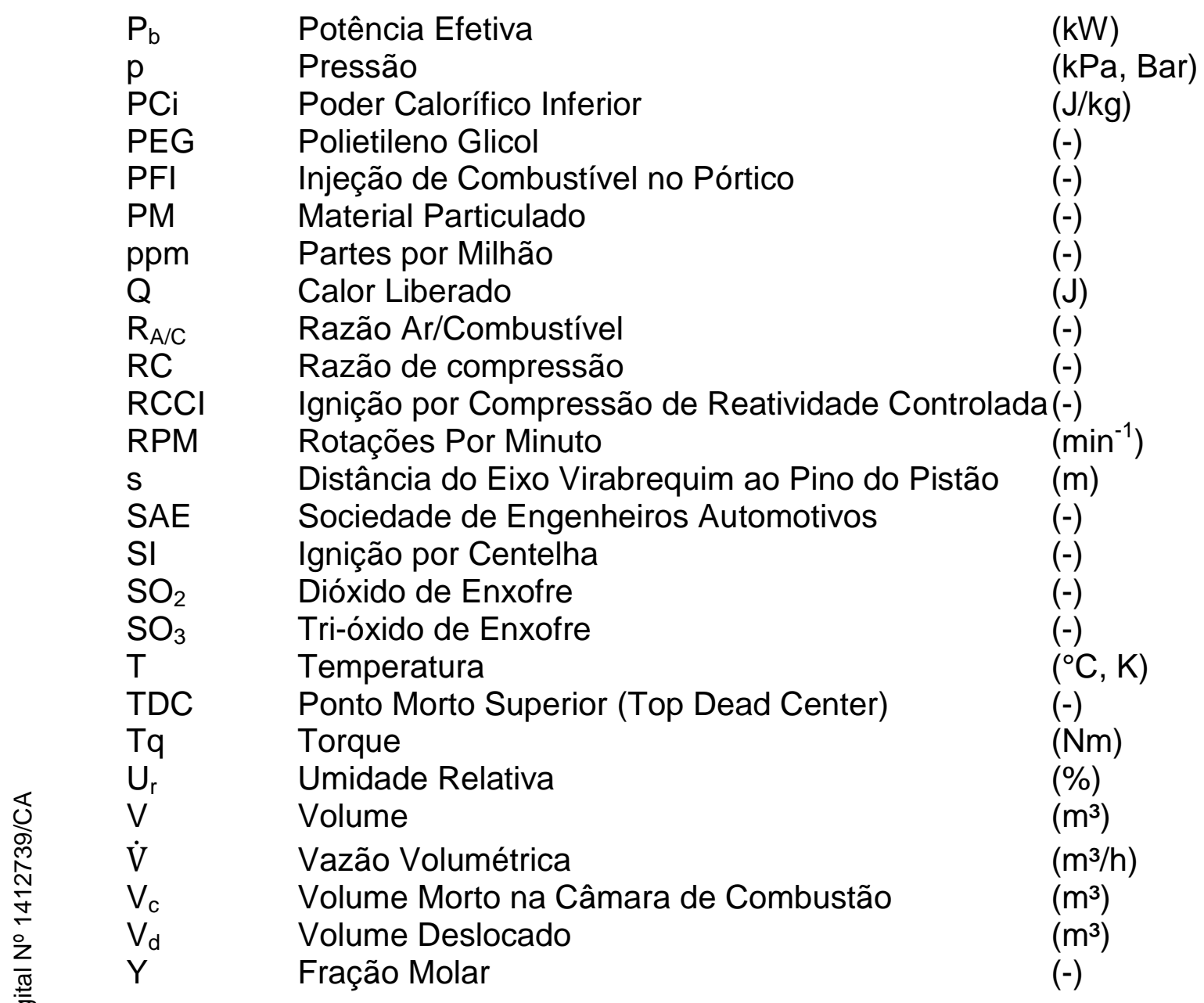

\section{Subscritos e Letras Gregas}

$\begin{array}{lll}\Delta \mathrm{T} & \text { Diferença de Temperatura } & \left({ }^{\circ} \mathrm{C} ; \mathrm{K}\right) \\ \phi & \text { Razão de Equivalência } & (-) \\ \gamma & \text { Razão entre Calores Específicos } & (-) \\ \mu & \text { Viscosidade } & (\mathrm{Pa} . \mathrm{s}) \\ \eta & \text { Rendimento ou Eficiência } & (\%) \\ \theta & \text { Ângulo de Virabrequim } & \left({ }^{\circ}\right) \\ \rho & \text { Densidade ou Massa Especifica } & \left(\mathrm{kg} / \mathrm{m}^{3}\right) \\ \omega & \text { Umidade Absoluta } & (-) \\ \mathrm{amb} & \text { Ambiente } & (-) \\ \mathrm{ar}, \mathrm{S} & \text { Ar Seco } & (-) \\ \mathrm{ar}, \mathrm{u} & \text { Ar Úmido } & (-) \\ \mathrm{C} & \text { Combustível } & (-) \\ \mathrm{D} & \text { Diesel } & (-) \\ \mathrm{E} & \text { Etanol } & (-) \\ r & \text { Referência } & (-) \\ \text { w } & \text { Água } & (-)\end{array}$




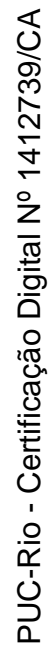

"Life is like riding a bicycle. To keep your balance, you must keep moving." Albert Einstein 


\section{Introdução}

\section{1}

\section{Contextualização}

A história do motor de combustão interna ( $\mathrm{MCl}$ ) começa a se desenhar de forma consistente no final do século XIX com os primeiros motores de ignição por centelha (SI - Spark Ignition) e de ignição por compressão $(\mathrm{Cl}$ Compression Ignition), desenvolvidos por Nikolaus Otto e Rudolf Diesel, respectivamente. Inicialmente projetados para aplicações de potência estacionária, posteriormente a invenção representaria também um grande marco na mobilidade humana, permitindo que as pessoas viajassem distâncias nunca antes imaginadas [1]. Desde então o $\mathrm{MCl}$ se transformou em um inestimável dispositivo de conversão de energia para a sociedade. A confiável geração de energia nas aplicações estacionárias e nos meios de locomoção, bem como a viabilidade econômica dos equipamentos, fizeram que em pouco tempo já houvesse produção em larga escala dos $\mathrm{MCl}$ para os mais diversos fins [2]. Pode-se dizer que Henry Ford inaugurou a fase moderna da industrialização ao instituir a linha de montagem, dando início à chamada produção em massa. Foi justamente o boom da indústria automobilística que desencadeou a utilização do petróleo e seus derivados como combustíveis tanto para veículos automotores quanto para equipamentos industriais, fazendo rapidamente o petróleo assumir a posição de domínio na matriz energética, substituindo o carvão mineral [3].

Porém, vale ressaltar que os motores a combustão interna não estagnaram no tempo. Muito pelo contrário, além de terem representado um marco revolucionário para o mundo, continuaram a se desenvolver, impulsionados à luz de novas tecnologias. Aos poucos, a eficiência de conversão de energia nos $\mathrm{MCl}$ pôde crescer significativamente, nutrida pelos avanços na engenharia envolvida nos materiais empregados, nas pressões de operação, nos sistemas de alimentação de ar e combustível e do conjunto do motor como um todo [1]. 


\section{2 Motivações}

Já há algum tempo a poluição nociva à saúde humana e ao meio ambiente, assim como a dependência do petróleo, são questões de extrema relevância no mercado de energia, despertando preocupações na sociedade, em órgãos reguladores e no mercado mundial. Neste âmbito, em meio ao crescimento dos biocombustíveis, inúmeras soluções tecnológicas têm sido pesquisadas e desenvolvidas, a fim de se reduzir o consumo de petróleo e derivados, bem como a emissão de poluentes. Em outras palavras, os referidos programas de desenvolvimento de $\mathrm{MCl}$ visam à obtenção de altas eficiências e baixas emissões [4].

\subsection{1}

\section{Substituição do Petróleo e seus Derivados}

Atualmente o petróleo ainda é a fonte energética primária dominante no mundo. Na verdade, esta hegemonia do petróleo já perdura há muitos anos e um reflexo disto é o fato de os derivados do petróleo terem sido os principais combustíveis utilizados nos veículos automotores durante todo o século XX. Apesar disto, tecnologias vêm consolidando combustíveis alternativos e conduzindo a uma tendência de que, progressivamente, a prevalência do petróleo possa ser substituída por outras fontes energéticas. A Figura 1, do Balanço Energético Nacional de 2016, mostra a predominância do petróleo no consumo energético brasileiro, no entanto o cenário apresentado também revela que outras fontes têm conquistado espaço no consumo energético do país ao longo dos anos.

A partir da década de 70 , o modelo poluente de desenvolvimento baseado no petróleo começava a ser posto em xeque. Até esta data, pouco mais de sessenta anos de utilização em larga escala já havia transcorrido e todas as projeções apontavam para o risco de esgotamento das reservas internacionais, o que contribuía para fortes elevações e instabilidades na cotação da commodity. 


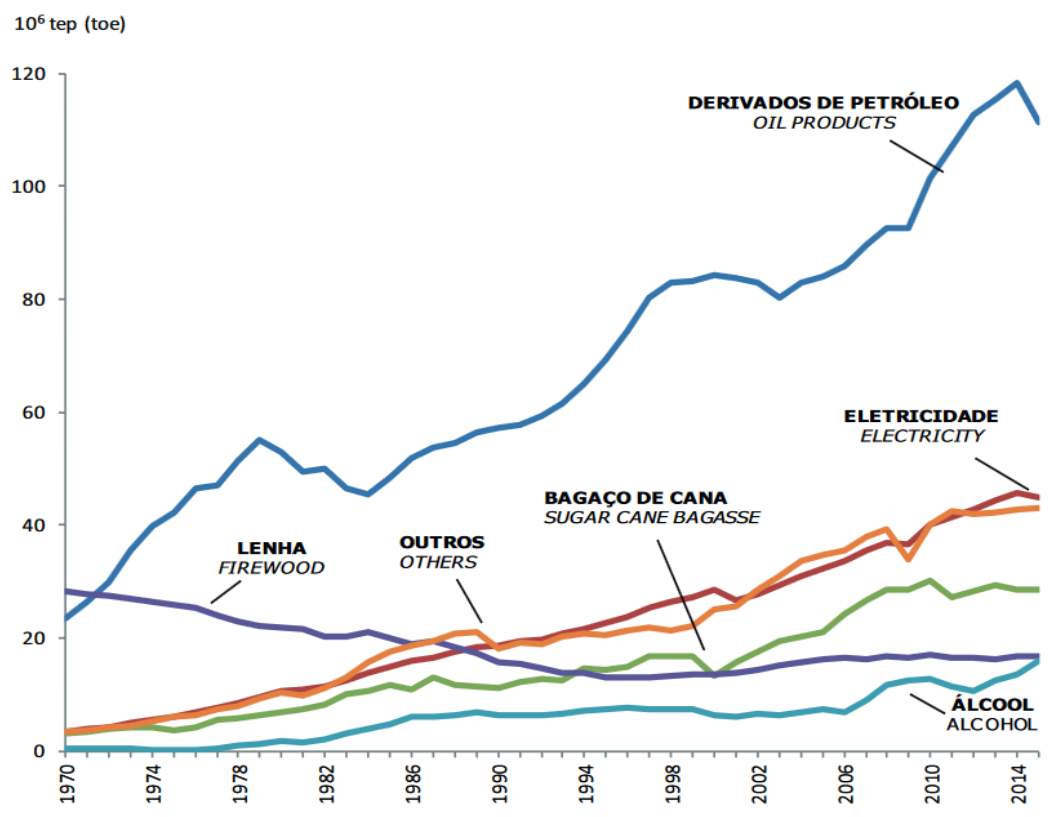

Figura 1 - Consumo final por fonte no Brasil de 1970 até 2015 [5]

Os choques do petróleo, as turbulências politicas envolvendo o Oriente Médio e a recessão mundial criaram um ambiente ideal para que diversas medidas fossem tomadas, a fim de que se reduzisse a dependência à fonte energética dominante. Cada país formulou sua política de Estado em uma tentativa de diversificar a matriz energética, na qual se destacou a fonte nuclear adotada por países como, por exemplo, Estados Unidos e França, além do pioneirismo brasileiro no desenvolvimento de biocombustíveis.

O álcool etílico foi o primeiro combustível renovável a ser utilizado em larga escala, o que muito se deu por sua viabilidade técnica e econômica. Este combustível alternativo conseguiu confirmar em pouco tempo as perspectivas do ISAF (International Symposium on Alcohol Fuels), as quais indicavam o etanol como um dos principais combustíveis na substituição total ou parcial de combustíveis fósseis.

Frente ao petróleo e seus derivados, o etanol destaca-se por ser uma fonte renovável de energia com características que permitem classificá-lo como um combustível limpo, podendo ser produzido a partir de diversas matérias-primas (cana-de-açúcar, beterraba, milho e trigo) em inúmeras regiões aptas ao cultivo e livres de tensões geopolíticas. Apesar da combustão do etanol apresentar um comportamento semelhante ao da gasolina, seu balanço final de dióxido de carbono permite afirmar que uma quantidade equivalente de $\mathrm{CO}_{2}$ emitida pelos motores a etanol na atmosfera é capturada pelo processo de crescimento da cana-de-açúcar, cultura que origina este álcool. 
Ao que tudo indica, pode ser que as próximas décadas marquem o fim da era dos combustíveis fósseis. Porém, ao contrário das expectativas do século passado, o fim da era não se daria pela exaustão das reservas, mas sim pela dinâmica econômica capitalista e crescentes restrições ambientais. Com as vantagens comparativas de uma enorme área agrícola apta à produção de etanol ainda inexplorada, insolação e experiência prévia na utilização de biocombustíveis, o Brasil pode aproveitar para se inserir como protagonista mundial dos combustíveis alternativos em um período no qual o petróleo enfrenta muitos questionamentos ambientais e econômicos [3].

No Brasil, a produção de etanol se orientou para o uso em motores de ignição por centelha através do Programa Nacional do Álcool (Proálcool), o maior e bem-sucedido programa de substituição de combustíveis derivados de petróleo do mundo [6]. Não obstante, já se enxergava no campo de pesquisas uma abrangência maior para as aplicações do combustível alternativo como, por exemplo, a participação dos álcoois também em motores de ignição por compressão, assunto que ainda será mais explorado na revisão bibliográfica do Capítulo 2.

No entanto, para a decepção daqueles empenhados nas pesquisas relacionadas ao etanol, durante a segunda metade da década de 1980 houve uma tendência marcante de redução da utilização do etanol, explicado pelo chamado contrachoque do petróleo. Neste período ocorreu o oposto da crise do petróleo, isto é, o preço do petróleo despencou e desestimulou a continuidade de pesquisas sobre combustíveis alternativos e renováveis.

Anos depois, os estímulos a novas pesquisas são retomados, agora não mais encorajados por questões petrolíferas somente, mas principalmente por restrições no âmbito das regulamentações ambientais. É então, que a viabilidade da substituição de combustíveis fósseis pelo etanol volta a se destacar como técnica robusta capaz de ser ao mesmo tempo uma alternativa à intensa dependência do petróleo e apresentar resultados promissores para eficiência térmica do motor, níveis de emissões e taxa de substituição de diesel.

Encorajado por resultados promissores na Suécia, Austrália, Chile, Alemanha e Tailândia, foi criado em 1997 no Brasil o Conselho Interministerial de Açúcar e do Álcool, o qual pode constituir grupos técnicos, reunindo agências governamentais, instituições de pesquisa, setor privado e organizações não governamentais. Coordenado pelo Ministério da Ciência e Tecnologia, existiram grupos que visavam ao estudo da viabilidade técnica de misturas contendo óleo diesel e etanol em motores de ignição por compressão. 
O Programa de Álcool e Diesel desenvolveu-se por duas vertentes: um projeto coordenado pela União dos Municípios Canavieiros do Estado de São Paulo e o outro pela Associação dos Produtores de Álcool e Açúcar do Paraná. No projeto de São Paulo é proposta uma mistura contendo entre 3\% a 10\% de etanol hidratado para formação de emulsão, enquanto o projeto do Paraná utiliza de $8 \%$ a $12 \%$ de etanol anidro com aditivos estabilizadores para a composição da solução. O intuito da aplicação de aditivos, utilizados em pequeníssimas quantidades, é garantir a homogeneidade, amenizar as características corrosivas e melhorar as propriedades cetânicas e de lubricidade da mistura ([7], [8] e [9]).

A introdução do biodiesel ao óleo diesel, formando uma mistura entre estes combustíveis, tem sido regulamentada pela legislação brasileira (vide item 2.1.4) nos últimos anos através da determinação de percentuais de adição obrigatória deste biocombustível ao diesel, de forma análoga à adição de etanol anidro na gasolina estabelecida no passado.

\section{2 .2 \\ Emissões}

O motor a combustão interna é um equipamento conversor de energia capaz de transformar potencial químico de combustíveis em trabalho útil através da combustão, mas também gera outros produtos prejudiciais tanto à saúde humana quanto ao meio ambiente. Tipicamente, em motores de fontes fósseis, pode-se listar a formação de alguns produtos: $\mathrm{CO}, \mathrm{CO}_{2}, \mathrm{HC}, \mathrm{PM}, \mathrm{SO}_{\mathrm{x}} \mathrm{e} \mathrm{NO}_{\mathrm{x}}$, no entanto as proporções das emissões variam bastante entre motores $\mathrm{Cl}$ e SI.

O monóxido de carbono (CO) é altamente tóxico, sem odor, cor, gosto e não irritante. Este gás é resultante da queima incompleta de combustíveis fósseis que contém carbono, o que significa que ele é obtido quando a operação no motor não possui oxigenação suficiente para converter todo o carbono disponível em $\mathrm{CO}_{2}$. Já os hidrocarbonetos $(\mathrm{HC})$ são combustíveis não queimados, ou seja, são frações de combustível que nem chegaram a oxidar. Os $\mathrm{HC}$ também estão relacionados à falta de oxigênio no processo ([1] e [8]).

Por outro lado, a formação de óxidos de nitrogênio $\left(\mathrm{NO}_{\mathrm{x}}\right)$ muito se deve às altas concentrações de oxigênio e altas temperaturas no interior dos $\mathrm{MCl}$. Sobretudo, estas emissões são compostas por óxido nítrico (NO), mas também existem parcelas de dióxido de nitrogênio $\left(\mathrm{NO}_{2}\right)$. Seguindo o mesmo princípio, as emissões de óxidos de enxofre $\left(\mathrm{SO}_{\mathrm{x}}\right)$ são proporcionais à quantidade deste elemento químico no combustível, bem como da disponibilidade de oxigênio na combustão. Grande parte da emissão se dá na forma de dióxido de enxofre 
$\left(\mathrm{SO}_{2}\right)$, mas dependendo das condições de temperatura e concentrações de oxigênio, também existem parcelas de $\mathrm{SO}_{3}$ [8].

Por fim, o material particulado (PM - Particulate Matter) é resultado da combustão das frações mais complexas de hidrocarbonetos em situações de insuficiência de oxigênio e de tempo para uma queima adequada. Este tipo de poluente é composto por materiais sólidos e líquidos que permanecem em suspensão na atmosfera devido ao seu pequeno tamanho [10].

A seguir, está apresentada a Tabela 1, organizada por Franco [11] em sua dissertação, na qual estão listados os principais impactos de gases de combustão à saúde humana e ao meio ambiente.

Tabela 1 - Principais impactos dos gases nocivos da combustão [11]

\begin{tabular}{|c|c|c|}
\hline Poluentes & Saúde Humana & Meio Ambiente \\
\hline $\begin{array}{l}\text { Monóxido de } \\
\text { Carbono (CO) }\end{array}$ & $\begin{array}{l}\text { Interfere no sistema respiratório. } \\
\text { Pode produzir danos ao coração e } \\
\text { cérebro, levar a mudanças nas } \\
\text { funções cardíacas e pulmonares, } \\
\text { fadiga e morte quando em altas } \\
\text { exposições. }\end{array}$ & $\begin{array}{l}\text { Tóxico para os animais, porém } \\
\text { nem tanto para as plantas. } \mathrm{O} \mathrm{CO} \\
\text { é capaz de se oxidar para } \mathrm{CO}_{2} \\
\text { beneficiando a fotossíntese das } \\
\text { plantas, mas contribuindo para o } \\
\text { efeito estufa. }\end{array}$ \\
\hline $\begin{array}{c}\text { Óxidos de } \\
\text { Nitrogênio }\left(\mathrm{NO}_{\mathrm{x}}\right)\end{array}$ & $\begin{array}{l}\text { Interfere no sistema respiratório. } \\
\text { Em altas concentrações pode } \\
\text { levar à morte. }\end{array}$ & $\begin{array}{l}\text { Pode levar à formação de ácido } \\
\text { nítrico (chuva ácida) ao reagir } \\
\text { com outras substâncias na } \\
\text { atmosfera. }\end{array}$ \\
\hline $\begin{array}{l}\text { Hidrocarbonetos } \\
\qquad(\mathrm{HC})\end{array}$ & $\begin{array}{l}\text { São irritantes para as mucosas e } \\
\text { olhos. Pode causar dor de cabeça, } \\
\text { vertigem, depressão, náuseas, } \\
\text { vômito, fadiga, fraqueza e diarreia. }\end{array}$ & $\begin{array}{l}\text { Podem apresentar } \\
\text { comportamentos diferentes no } \\
\text { ambiente, mas os impactos são } \\
\text { relacionados à formação de } \mathrm{CO}_{2} \\
\text { (efeito estufa). }\end{array}$ \\
\hline $\begin{array}{l}\text { Material } \\
\text { Particulado } \\
\quad(\mathrm{PM})\end{array}$ & $\begin{array}{l}\text { Interfere no sistema respiratório, } \\
\text { na visão, sistema imunológico, } \\
\text { coração e pode causar toxicidade } \\
\text { sistemática. }\end{array}$ & $\begin{array}{l}\text { Capaz de alterar os níveis de } \\
\text { visibilidade, ecossistemas } \\
\text { (fertilização, acidificação e etc.) e } \\
\text { degradar materiais de } \\
\text { construção. }\end{array}$ \\
\hline $\begin{array}{c}\text { Dióxido de } \\
\text { Enxofre }\left(\mathrm{SO}_{2}\right)\end{array}$ & $\begin{array}{l}\text { É irritante às vias nasais e olhos, } \\
\text { provoca agravamento de doenças } \\
\text { respiratórias e cardiovasculares } \\
\text { quando já existentes. }\end{array}$ & $\begin{array}{l}\text { Ao oxidar-se em diferentes } \\
\text { meios, pode reagir com a } \\
\text { umidade do ambiente e produzir } \\
\text { partículas de ácido sulfúrico } \\
\left(\mathrm{H}_{2} \mathrm{SO}_{4}\right) \text {. }\end{array}$ \\
\hline
\end{tabular}

Como já mencionado anteriormente, o dióxido de carbono é outro dos gases emitidos no processo de combustão dos derivados de petróleo. Apesar de o $\mathrm{CO}_{2}$ não ser tão tóxico quanto os demais poluentes dos motores de combustão interna, o meio ambiente sofre com suas emissões que acontecem em larga 
escala. $O$ efeito estufa, que ocorre naturalmente no planeta pelo acúmulo de gases na atmosfera (sobretudo do $\mathrm{CO}_{2}$ ), é responsável por reter a radiação infravermelha do sol, não permitindo que o calor incidente sobre a Terra seja refletido de volta para o espaço de forma integral. Entretanto desde o início do último século, a dinâmica econômica mundial tem ampliado exponencialmente o lançamento de gases na atmosfera, incluindo o gás carbônico. Então, ao que tudo indica, quantidades excessivas de $\mathrm{CO}_{2}$ no meio ambiente intensificam o fenômeno do efeito estufa, potencializando elevações de temperaturas globais e efeitos climáticos, por vezes catastróficos [3]

Vale ressaltar que, no âmbito nacional, o setor de transportes, que utiliza massivamente os $\mathrm{MCl}$, contribui não só com a emissão de gases nocivos, mas também com a parcela mais significativa de $\mathrm{CO}_{2}$, conforme mostra a Figura 2 do Relatório Síntese da referência [5]:

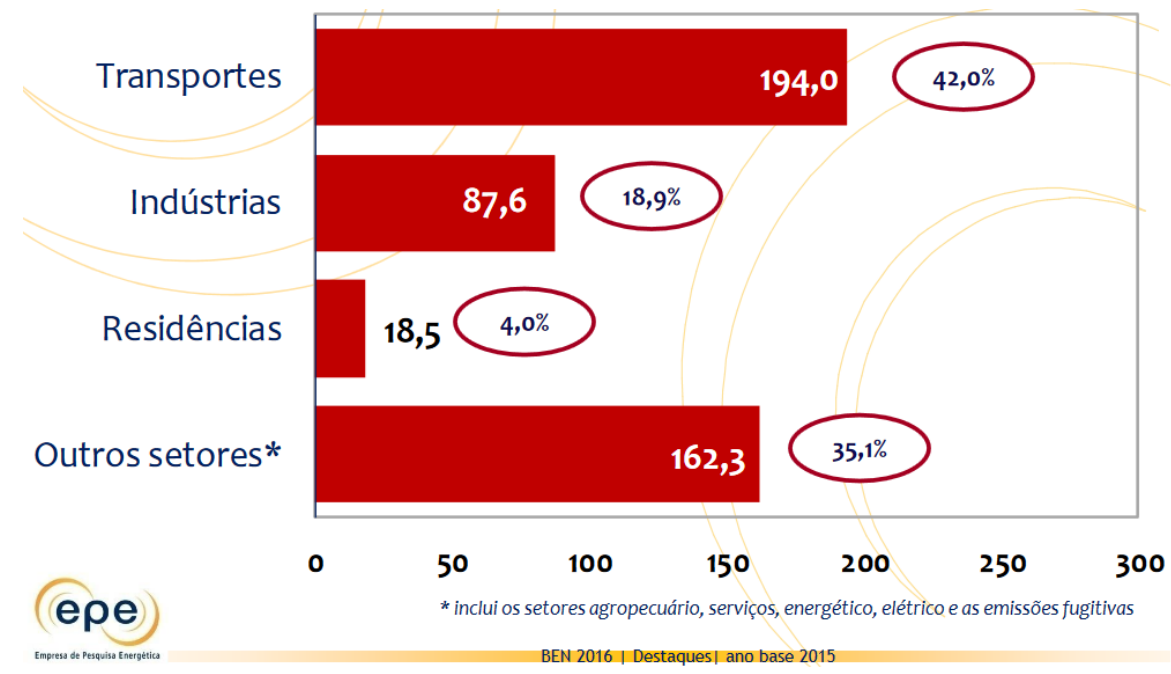

Figura 2 - Emissões totais em Mt de $\mathrm{CO}_{2}$ no Brasil em 2015 [5]

Portanto, com o uso altamente difundido do $\mathrm{MCl}$, discussões sobre emissões de poluentes têm sido levantadas com crescente preocupação pela sociedade e órgãos reguladores, pressionando as indústrias a reduzirem as emissões, através de constantes melhorias nos $\mathrm{MCl}$, na qualidade dos combustíveis e nos sistemas de pós-tratamento para o atendimento das crescentes exigências ambientais. No Brasil, o CONAMA (Conselho Nacional de Meio Ambiente) instituiu em 1986 o Programa de Controle da Poluição do Ar por Veículos Automotores (PROCONVE), o qual prioriza o segmento de veículos leves, devido ao seu grande número e utilização extensiva. As normas e limites deste programa são norteados por legislações de países da Europa e dos Estados Unidos com as devidas adaptações às condições e necessidades 
brasileiras [4]. A Figura 3 [12] exemplifica como a cada edição os principais órgãos reguladores internacionais se tornam mais rígidos. Nesta figura são apresentados limites toleráveis de emissões de $\mathrm{NO}_{x}$ e PM para o Euro (órgão regulador europeu) e EPA (órgão regulador norte americano - Environmental Protection Agency), nos quais o Brasil muito fundamenta seu programa regulador de emissões.

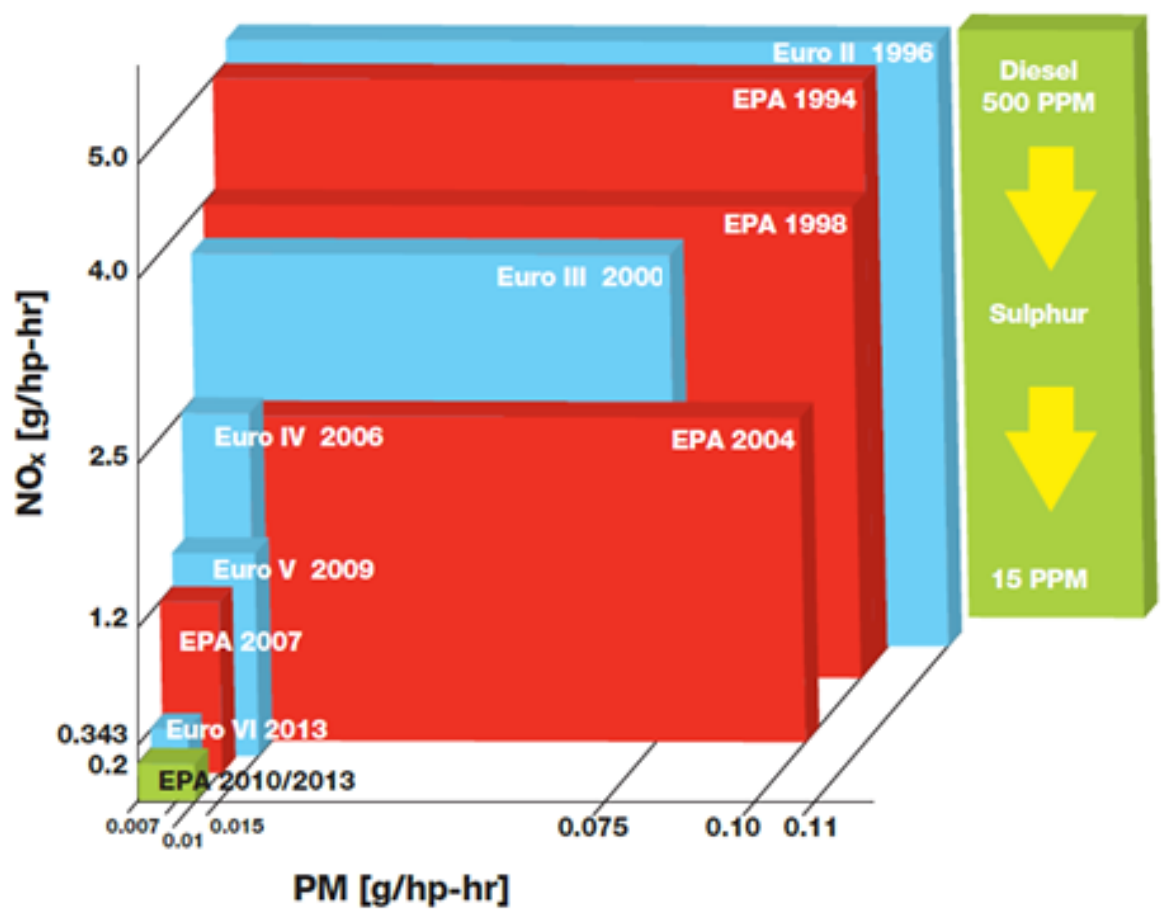

Figura 3 - Histórico de limites de emissões EPA e Euro $\left(\mathrm{NO}_{x}\right.$ e PM)

Com isso, sabe-se que a busca por motores mais eficientes tem sido muito motivada não só pela redução do consumo, como também pela amenização das emissões. Neste sentido, é notável como ultimamente os motores de ignição por compressão com injeção direta (DI), equipados com sistemas de injeção de alta pressão (common rail), com óleo diesel, têm se posicionado de forma vantajosa no setor automotivo. De acordo com a Associação de Fabricantes Europeus de Automóveis, motores do tipo ignição por compressão consomem aproximadamente $30 \%$ menos combustível e emitem em média $25 \%$ menos $\mathrm{CO}_{2}$, quando comparados aos motores do tipo ignição por centelha [13]. Muito embora os motores deste tipo sejam considerados respeitosos com o meio ambiente, pelo mencionado menor consumo e consequente menor emissão de $\mathrm{CO}_{2}$, estes não são isentos de desvantagens. Altos níveis de óxidos de nitrogênio $\left(N \mathrm{~N}_{\mathrm{x}}\right)$, material particulado $(\mathrm{PM})$ e ruído na combustão são desvantagens de motores de ignição por compressão tradicionais que, inclusive, 
fomentam o estudo de biocombustíveis em motores deste tipo na expectativa de que os efeitos prejudiciais para o meio ambiente e para a saúde humana sejam minimizados.

Assim a melhor compreensão do processo de combustão na operação do tipo ignição por compressão contribui para otimizações nos motores $\mathrm{Cl}$ através de pesquisas relacionadas à substituição total ou parcial do óleo diesel por combustíveis de fontes renováveis, que permitam baixos consumos aliados a menores emissões de poluentes.

\section{3 \\ Objetivo}

Neste trabalho, através de testes em um motor diesel MWM 4.10 TCA com razão de compressão de 15,8:1 acoplado a um dinamômetro, foi estudada a combustão de diferentes combustíveis para algumas condições de rotação, torque e instantes de injeção de combustível.

Dentre os objetivos do estudo, destaca-se o enfoque investigativo do aumento das proporções de etanol nas misturas de óleo diesel comercial, biodiesel e etanol via ignição por compressão, submetidas à aplicação de pequena concentração de aditivo para que a estabilidade monofásica seja assegurada. Para isto, são necessárias avaliações dos processos de combustão e do desempenho do motor quando abastecido pelas misturas ternárias.

Esta dissertação consiste em uma continuidade do estudo iniciado por Pradelle [14], que também avaliou misturas Diesel/Biodiesel/Etanol neste mesmo motor em sua tese de doutorado. Assim, aprofundando-se o estudo em direção às avaliações com diferentes instantes de injeção de combustível, pretende-se aprimorar o conhecimento a respeito da utilização de significativas parcelas de biocombustíveis na substituição parcial do óleo diesel de maneira tão eficiente quanto à tradicional ignição por compressão convencional com diesel.

Antes da execução dos testes desta dissertação é importante listar alguns procedimentos que melhor direcionem o foco desta pesquisa:

- Relacionar estratégias de substituição parcial ou integral do diesel por biocombustíveis em motores de ignição por compressão;

- Descrever combustíveis, aditivos e misturas elegíveis ao uso em motores de ignição por compressão;

- Buscar na literatura sobre a melhora na miscibilidade entre biocombustíveis e o óleo diesel, além da estabilização de misturas por aditivos de caráter renovável; 
- Estabelecer instantes otimizados de injeção das misturas, fundamentados em uma metodologia que avalie as relações entre propriedades físico-químicas dos componentes e estimativas do instante da autoignição nos processos de combustão, de acordo com resultados disponíveis na literatura.

\section{4 \\ Conteúdo do trabalho}

A presente dissertação se desenvolve ao longo de seis capítulos. No Capítulo 1 deste trabalho apresenta-se uma breve contextualização histórica dos $\mathrm{MCl}$ na sociedade, seguida das principais motivações para a crescente participação de fontes alternativas no campo de pesquisas da substituição de combustíveis fósseis e, por último, os objetivos deste trabalho.

No Capítulo 2 é realizada uma revisão bibliográfica, mostrando-se conceitos da ignição por compressão, estratégias para a substituição dos combustíveis fósseis e um levantamento do estado da arte dos resultados já obtidos por autores e grupos de pesquisas que têm trabalhado com misturas entre biocombustíveis, óleo diesel e eventualmente aditivos necessários à operação apropriada em motores de ignição por compressão.

O Capítulo 3 descreve o aparato experimental da dissertação, i.e., a descrição do motor MWM 4.10 TCA, bem como o funcionamento e as características do dinamômetro e os sistemas auxiliares a este nos testes do presente trabalho. Neste capítulo também está apresentado o procedimento experimental que esclarece a metodologia adotada para a execução dos testes.

Já no Capítulo 4 estão indicadas as fundamentações teóricas em que se detalham os equacionamentos empregados na análise de dados experimentais e cálculos das variáveis de interesse, a fim de que no Capítulo 5 sejam exibidos os resultados do trabalho acompanhados de comentários e discussões pertinentes.

Finalmente no Capítulo 6 encerra-se a dissertação com conclusões e posicionamentos finais sobre o conteúdo abordado e testado, bem como sugestões para estudos futuros no âmbito da substituição de fontes fósseis por renováveis nos motores de ignição por compressão. Logo após este último capítulo, encontram-se disponíveis todas as referências bibliográficas deste trabalho, assim como apêndices e anexos que incluem as metodologias para análise de incertezas, caracterizações de combustíveis, planilhas de resultados experimentais e demais detalhamentos técnicos. 


\section{2 Revisão Bibliográfica}

Neste capítulo, são apresentadas as revisões de conceitos e características básicas de motores de ignição por compressão, que são fundamentais para um melhor entendimento das principais tecnologias disponíveis no que se refere à substituição dos combustíveis fósseis. Neste contexto, é dada uma ênfase maior ao uso de combustíveis renováveis, tais como o etanol e o biodiesel, misturados ao óleo diesel em motores de ignição por compressão. Com isso, destacam-se resultados já alcançados por estudos anteriores que tenham, porventura, avaliado o uso de técnicas de aplicação de biocombustíveis em detrimento dos combustíveis fósseis neste tipo de motor.

Por mais que, existam significativas relações entre os processos desencadeados durante a combustão e os princípios de cinética química, estes não foram considerados isoladamente no trabalho, já que não representam o foco desta pesquisa.

\section{1 \\ Combustão de Ignição por Compressão - Diesel Convencional}

Notadamente, o motor a ignição por compressão movido a diesel é o mais eficiente dentre os comercializados no mercado atual. Porém, quando comparado aos motores de ignição por centelha, o motor a diesel apresenta tanto vantagens quanto desvantagens no quesito emissões. Se por um lado a emissão de produtos de combustão incompleta ( $\mathrm{CO}$ e $\mathrm{HC})$ é pequena, já não se pode dizer o mesmo das emissões de $\mathrm{NO}_{x}$ e PM [15].

Tendo em vista que a combustão de ignição por compressão é a base deste trabalho, é então importante compreender como se dá o processo de combustão a diesel convencional (CDC), o qual se utiliza da ignição por compressão. A combustão diesel é diferente da combustão de ignição por centelha em alguns aspectos, dentre eles destaca-se a não utilização de centelha para o início da combustão, uma vez que as condições favoráveis de pressão e temperatura da carga são suficientes para conduzir à autoignição de um combustível com alta reatividade. A mencionada carga, por sua vez, é definida pela quantidade injetada de combustível e pela vazão de ar que flui sem 
restrição (unthrottled), caracterizando geralmente misturas com excesso de ar, também chamadas de misturas pobres.

A CDC se desencadeia através de um processo de difusão de chama instável e turbulenta em que o combustível encontra-se inicialmente na fase líquida, desintegrando-se na forma de pequenas gotículas quando injetado [1]. A orientação do spray que sai do bico injetor é fundamental para o processo inicial da mistura ar/combustível tanto nas injeções diretas quanto nas indiretas, possibilitando a vaporização, após a referida desintegração em pequenas gotículas, que leva ao início da combustão.

Na Figura 4 está representado um modelo conceitual do processo de combustão diesel da obra de Jarosinski et al. [16] e adaptado por Ccacya [4].

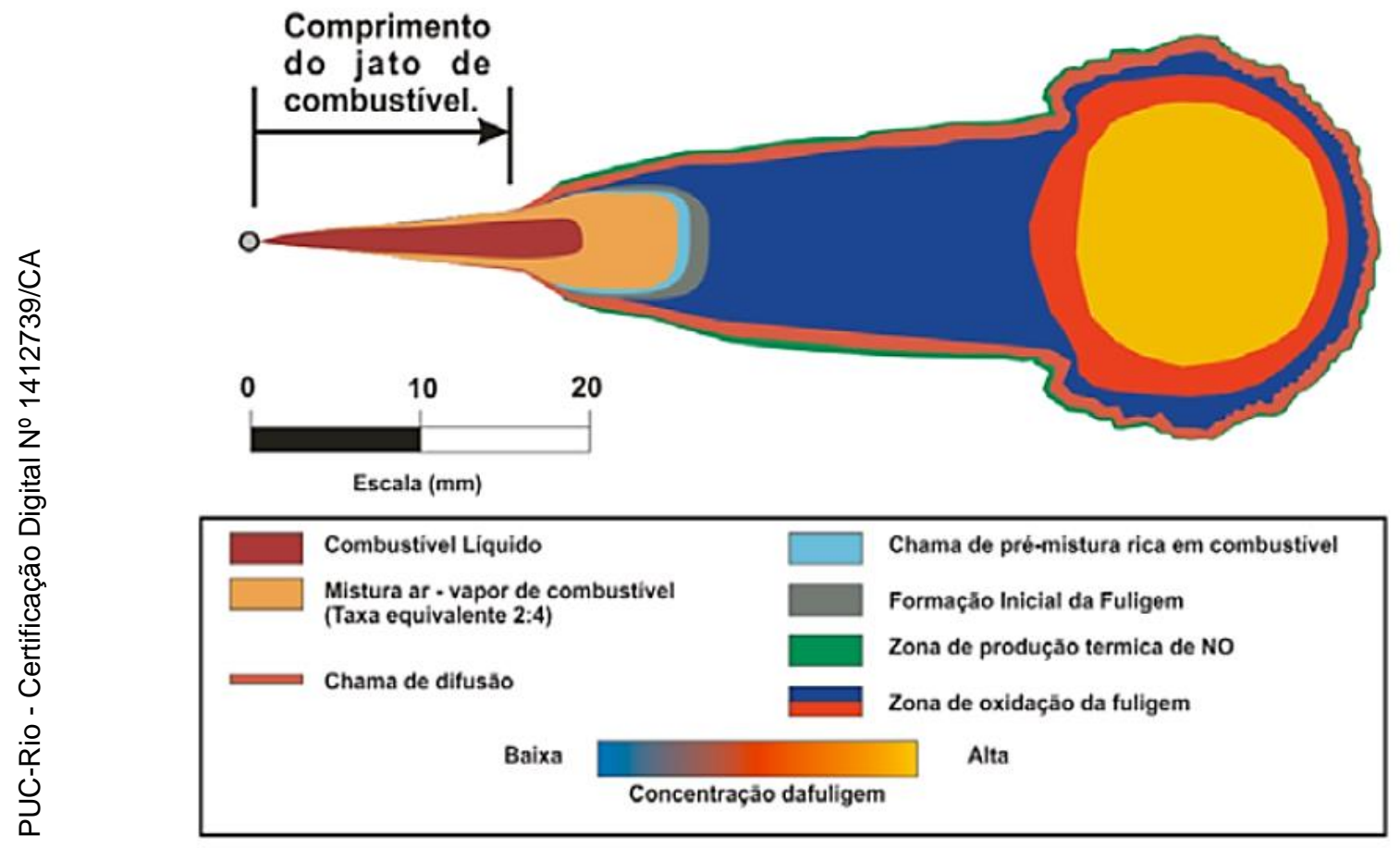

Figura 4 - Modelo conceitual da combustão Diesel Convencional [4]

A estrutura do jato apresentada mostra o núcleo de combustível líquido, presente durante todo o processo de injeção, e auxiliado pela turbulência do ar arrastado que favorece a evaporação das gotículas do combustível. Há uma região relativamente uniforme com razão de equivalência $(\phi)$ entre 2-4 (região onde a razão entre mistura ar/combustível estequiométrica e mistura ar/combustível real é alta e rica em combustível, ou seja, 2 a 4 vezes a relação estequiométrica) que se estende na frente e ao redor do núcleo líquido. Já a região de queima da pré-mistura delimita a zona gasosa ar/combustível, onde a chama desta pré-mistura gera partículas sólidas (PM) e hidrocarbonetos 
aromáticos policíclicos que incrementam de concentração e tamanho na direção da cabeça do vórtice, rodeada por uma delgada chama de difusão, conforme pode ser observado na Figura 4. A mencionada chama de difusão é a zona de reação dos produtos da chama de pré-mistura com os arredores, ricos em quantidade de oxigênio. Vale destacar que as altas temperaturas de difusão de chama e a concentração de moléculas de oxigênio geram condições bem propícias à produção de $\mathrm{NO}_{x}[16]$.

Felizmente a emissão de produtos de combustão incompleta não é um problema para os motores diesel convencional. Neste tipo de motor não existe a tendência de HC se depositar pelos cilindros, já que tipicamente não há injeções no começo do ciclo, bem como a mistura ar/combustível é rica em ar. Este excesso de ar aliado às altas temperaturas no interior do cilindro favorecem a oxidação de $\mathrm{CO}$ e $\mathrm{HC}$ para produtos de combustão completa: $\mathrm{H}_{2} \mathrm{O}$ e $\mathrm{CO}_{2}$. Por outro lado, conforme já descrito, a formação de $\mathrm{NO}_{x}$ e $\mathrm{PM}$ é inerente ao processo CDC. Apesar disto, a indústria tem se mobilizado nas últimas décadas em busca de avanços tecnológicos capazes de superar as barreiras impostas por órgãos reguladores de emissões. A Figura 5, da tese de Martínez [17], ilustra alguns desenvolvimentos técnicos nos motores diesel convencional nas últimas décadas, os quais têm assegurado a sobrevivência deste tipo de motor até os dias de hoje.

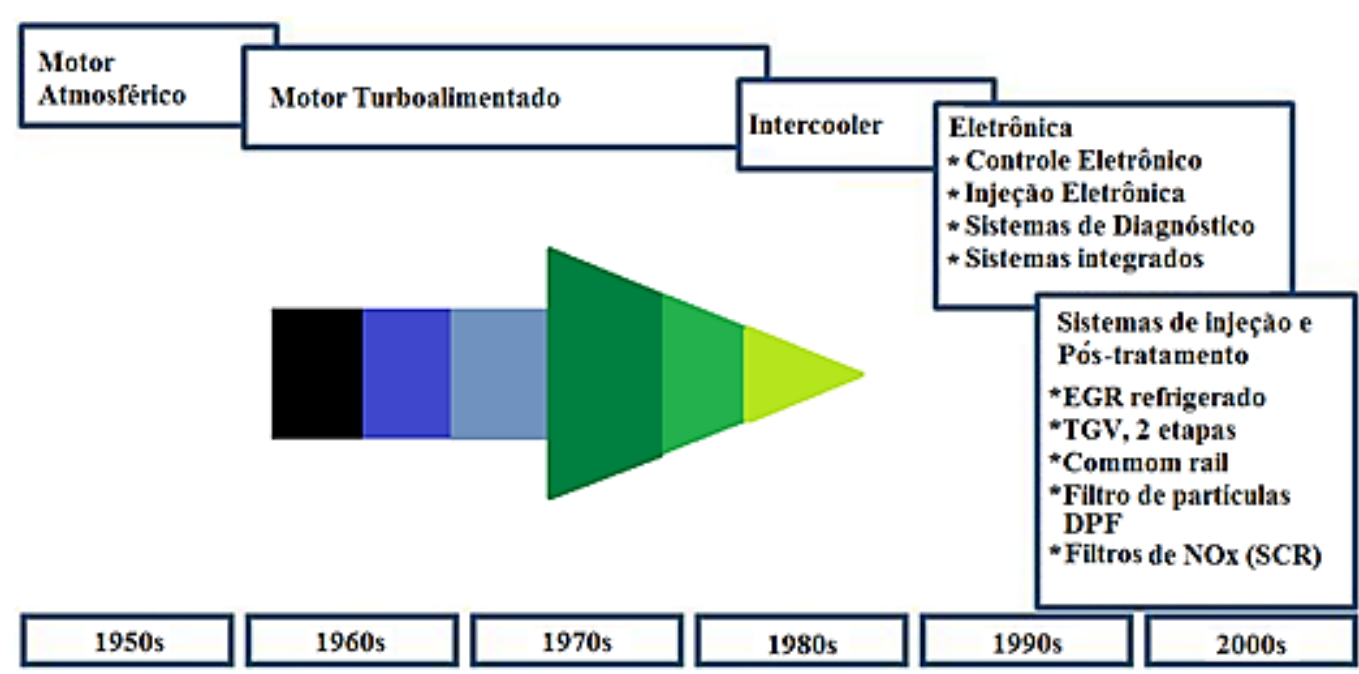

Figura 5 - Evolução técnica do motor $\mathrm{CI}$ nas últimas décadas [17]

Para resumir todo o processo CDC, a Figura 6, do livro de Heywood [1], apresenta uma descrição temporal deste tipo de combustão, seguido por breves interpretações dos fenômenos que ocorrem durante o processo: 


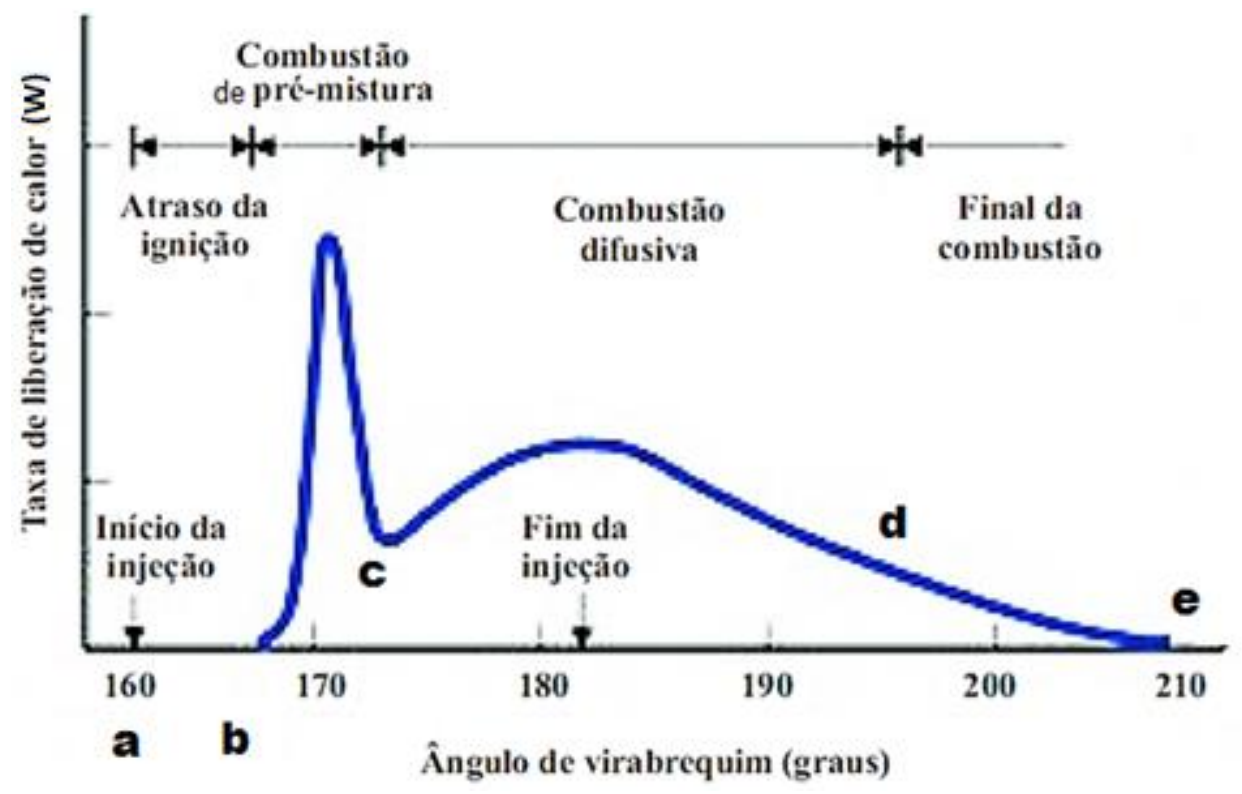

Figura 6 - Desencadeamento temporal do processo CDC

- Trecho a-b: Este primeiro trecho refere-se ao atraso da ignição (abordado no item 2.1.1), o qual diz respeito ao intervalo entre o instante de início da injeção de combustível até o início da combustão;

- Trecho b-c: No segundo trecho acontece a combustão da pré-mistura, a qual é uma combustão rápida que acontece logo após o início da combustão e perdura até o ponto de máxima pressão do ciclo. Vale destacar que é neste trecho que ocorre o ruído característico do funcionamento dos motores CDC por causa da elevação repentina de pressão que, por sua vez, é justificada pela disponibilidade de combustível já misturado ao ar e pronto para queimar de maneira acelerada devido à cinética dos gases;

- Trecho c-d: O terceiro trecho do processo é a combustão difusiva que sucede o momento de combustão da pré-mistura. Neste trecho, também conhecido como combustão controlada, a combustão se propaga de forma mais lenta, pois há a dependência da taxa com que a mistura encontra-se disponível para que haja a queima. Esta fase da combustão é realizada por frente de chama, em que ocorre o fenômeno da difusão pela câmara de combustão que alcança as parcelas da mistura ar/combustível que ainda não estavam propícias à autoignição;

- Trecho d-e: Neste trecho final do processo de combustão, que ainda se dá de forma difusiva, os reagentes e a liberação de energia são cada vez menores até o final do ciclo determinado pela abertura das válvulas de exaustão. Simultaneamente, a cinética química dos gases decresce com a redução das concentrações de reagentes, assim como também pela queda de temperatura e 
pressão no interior do cilindro, causada naturalmente pelo curso de expansão. Ressalta-se ainda que esta etapa da combustão caracteriza-se pela significativa produção de material particulado e grande perda de calor por radiação.

\subsection{1}

\section{Atraso da Ignição}

O atraso da ignição (ID - Ignition Delay) é, conforme já mencionado, o intervalo de tempo entre o início da injeção de combustível (estipulado pelo avanço estático ajustado na bomba distribuidora BOSCH VE) e o início da combustão [1], configurando-se como um parâmetro de extrema importância para o fenômeno de combustão. O intervalo de tempo do atraso da ignição está associado à fase de preparo da carga entre a admissão de combustível na câmara e o início da ignição desta carga, portanto o desenho/geometria e o desempenho exigido do motor em questão influenciam diretamente na extensão do intervalo. Também existem diversos outros fatores que podem potencialmente interferir no atraso da ignição, conforme listado abaixo [1]:

- Temperatura do ar admitido: o aumento da temperatura admitida, obviamente, implica em maiores temperaturas do ar comprimido, melhorando a vaporização do combustível, o que diminui o atraso da ignição. No entanto, o aumento da temperatura do ar também resulta em reduções de sua densidade, que influenciam diretamente a eficiência volumétrica e a potência, reduzindo-as;

- Pressão do ar admitido: o aumento da pressão do ar admitido eleva a pressão e também a temperatura do ar comprimido, reduzindo a temperatura de autoignição e o atraso de ignição;

- Razão de compressão: o aumento da razão de compressão minimiza o valor do atraso da ignição, o que acontece pela elevação das pressões e temperaturas do ar presente no interior da câmara de combustão, bem como pela menor temperatura de autoignição devido ao aumento da densidade do ar;

- Rotação do motor: o aumento da velocidade de funcionamento do motor minimiza as quedas de temperatura durante o processo de compressão, possibilitando acréscimos na temperatura e pressão do ar que, por consequência, diminuem o atraso da ignição;

- Potência: o aumento da potência se traduz em uma redução da relação ar/combustível, o que gera incrementos de temperatura e, por conseguinte, uma diminuição no atraso da ignição;

- Atomização: a maior atomização do combustível injetado, ou seja, um maior refinamento do spray de injeção reduz o atraso da ignição; 
- Avanço da injeção de combustível: o instante em que acontece a injeção de combustível é um dos fatores que mais influencia o atraso da ignição, já que injeções mais adiantadas levam o combustível a se deparar com condições de temperaturas menores para o ar contido no cilindro, aumentandose o atraso da ignição;

- Qualidade do combustível: o número de cetano é um relevante indicador da qualidade de ignição do combustível, número este que se relaciona diretamente com o atraso de ignição, em que quanto menor o número de cetano maior é o atraso da ignição. Em relação à tensão superficial, combustíveis com maiores viscosidades e menores volatilidades apresentam atrasos da ignição mais representativos, em virtude da atomização de combustível desfavorecida.

Para uma melhor compreensão do fenômeno de atraso de ignição, é pertinente dividi-lo em duas partes: o atraso físico e o químico.

O atraso físico, governado principalmente pela viscosidade do combustível (combustíveis mais viscosos tendem a apresentar maiores atrasos), é o intervalo entre o início da injeção até o instante em que sejam alcançadas as condições propícias para as reações químicas do processo de combustão. Durante esta etapa o combustível é atomizado, vaporizado, misturado ao ar e condicionado até a temperatura de autoignição.

Já na etapa de atraso químico, a velocidade com que as reações se desencadeiam é crescente até que as condições de ignição sejam atingidas. A velocidade das reações é maior em temperaturas mais elevadas, o que significa que o atraso químico depende profundamente das condições de temperatura do processo. Com isso, quando as temperaturas são expressivas, o atraso físico é tipicamente mais longo do que o atraso químico [18].

\subsection{2 \\ Detonação}

O nome detonação (knock) é dado ao ruído característico transmitido através da estrutura do motor, quando ocorre a ignição espontânea de uma porção da carga. A detonação é um mau funcionamento que, em casos extremos, pode causar danos severos ao motor. Por isso, o esclarecimento do fenômeno é essencial para a prevenção de danos durante a operação do motor.

Neste processo anormal de combustão há uma liberação extremamente rápida de grande parte da energia química contida na mistura ar/combustível, causando pressões locais elevadas e a propagação de ondas de pressão com amplitude substancial através da câmara de combustão. 
A ocorrência do knock depende das características do combustível utilizado e da adequação do projeto do motor em suas condições operacionais garantindo pressões, temperaturas e distribuições de carga apropriadas ao combustível utilizado. O número de cetano traz à tona a habilidade de combustíveis em sofrer a autoignição nos motores de ignição por compressão: quanto maior é o índice, mais fácil é a autoignição. Já o projeto do motor está relacionado às pressões e temperaturas que a carga atinge durante as condições operacionais e da agilidade com que as misturas ar/combustível são adequadamente formadas no interior do cilindro.

Além de colocar em risco a integridade estrutural do motor, o fenômeno da detonação afeta diretamente o desempenho pela restrição de sua eficiência, uma vez que tal fenômeno inevitavelmente limita as condições de pressões e temperaturas dentro do cilindro ou, em última análise, a razão de compressão do motor [1].

A Figura 7, do livro de Heywood [1], ilustra mais detalhadamente a variação de pressão no interior do cilindro diante de três ciclos diferentes de um motor: ciclo com combustão normal, ciclo com suave detonação e ciclo com detonação severa. Quando a detonação ocorre é possível notar as flutuações de alta frequência da pressão que são resultantes da espontânea e repentina liberação de grande parte da energia química da carga, o que produz aumentos localizados de pressão e temperatura em determinados pontos da câmara, causando a propagação de uma onda de choque. O caráter oscilatório da curva de pressão em função do tempo está associado à reflexão destas ondas de choque pelas paredes da câmara.

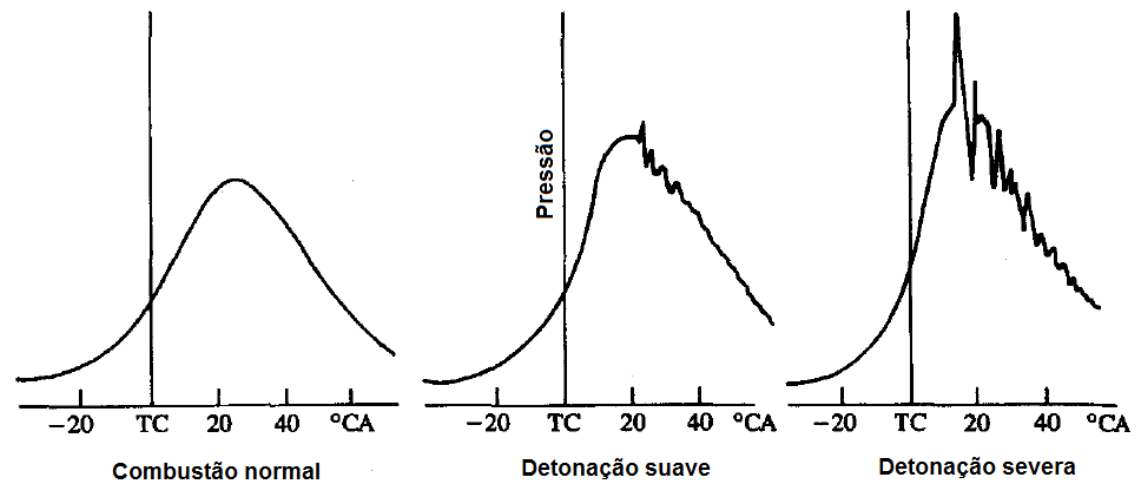

Figura 7 - Efeitos da detonação pela curva de pressão 


\subsection{3 Óleo Diesel}

Largamente difundido nas mais diversas aplicações em motores atualmente (caminhões, ônibus, furgões, automóveis de passeio, tratores, locomotivas, máquinas agrícolas, embarcações, aplicações estacionárias para geração de energia elétrica e etc.), o óleo diesel é essencialmente um combustível fóssil derivado de petróleo formado por hidrocarbonetos. Além dos átomos de hidrogênio e carbono, há também em sua composição oxigênio, nitrogênio e enxofre, porém em baixas concentrações. No Brasil, o óleo diesel disponibilizado pela Petrobras desde janeiro de 2013, chamado de Diesel S 10, possui teor máximo de enxofre de $10 \mathrm{mg} / \mathrm{kg}$ visando ao atendimento dos requisitos das mais novas gerações de motores diesel, projetados para emitir menores quantidades de material particulado e $\mathrm{NO}_{x}[19]$.

Apesar da complexa composição do diesel, em razão do grande número de hidrocarbonetos que o compõem, é possível classificá-lo em três grupos, representados por seus principais hidrocarbonetos: dodecano $\left(\mathrm{C}_{12} \mathrm{H}_{26}\right)$, tridecano $\left(\mathrm{C}_{13} \mathrm{H}_{28}\right)$ e tetradecano $\left(\mathrm{C}_{14} \mathrm{H}_{30}\right)$ [20]. O dodecano é o mais empregado em motores de ignição por compressão, operando em regimes acima de 1200 RPM em aplicações veiculares ou estacionárias [21].

Há certas propriedades do combustível capazes de influenciar diretamente no processo de injeção e na formação da mistura ar/combustível, tais como: volatilidade, densidade e viscosidade. Portanto, a composição química do combustível, que está relacionada com o tipo de petróleo (matéria-prima) e também aos processos de produção nas refinarias, sempre influencia o desempenho da combustão e da máquina térmica [22]. O número de cetano representa um importante parâmetro que indica a qualidade de ignição do combustível, caracterizando a cinética química da combustão (inclusive o atraso da ignição) e influenciando no espectro de substâncias emitidas pelo motor [1]. Para as operações em motores de ignição por compressão o número de cetano, geralmente, situa-se entre 40 e 60 . Vale ressaltar que valores inferiores a 40 implicam em maior presença de fumaça na descarga, perda de potência, aumento de consumo e dos níveis de ruído, enquanto maiores números apontam para uma melhor capacidade de queima do combustível [23].

No Apêndice A estão dispostas algumas propriedades do diesel puro, conforme a dissertação de Ferrari Filho [24]. Já no Anexo B apresenta-se a caracterização do óleo diesel comercial dos testes deste trabalho. 


\subsection{4 Biodiesel}

A ASTM International (American Society for Testing and Materials) define o biodiesel como uma mistura de longa cadeia de ésteres monoalquílicos de ácidos graxos obtidos por recursos renováveis para ser utilizada em motores de ignição por compressão. O biodiesel é um biocombustível líquido que pode ser utilizado em motores de ignição por compressão em alternativa ao óleo diesel, substituindo-o integralmente ou parcialmente através de misturas. Nas misturas diesel/biodiesel a indicação da concentração do biocombustível é dada pela sigla "Bx", na qual " $x$ " anuncia a porcentagem volumétrica de biodiesel na mistura. Por exemplo, "B5" refere-se a uma mistura diesel/biodiesel em que há $5 \%$ de biodiesel e 95\% de diesel puro em volume [25].

O biocombustível é produzido a partir de óleos vegetais ou gorduras animais e álcool por uma reação de transesterificação. Este processo químico converte um éster, advindo do óleo vegetal ou gordura animal, em uma mistura de ésteres dos ácidos graxos que compõem o óleo. Existem diversos óleos vegetais que servem de matéria-prima, tais como: soja, coco, mamona, algodão, palmeira, canola, girassol, amendoim e outros, assim como também sebo bovino que representa uma matéria-prima de gordura animal. No Brasil, a soja é a principal fonte para a produção do biodiesel, seguida do sebo bovino [26].

Além de ser um combustível renovável, o biodiesel apresenta também outras vantagens frente ao diesel [25]:

- Baixa toxidade, menor risco à saúde e emissões inferiores de monóxido de carbono, material particulado, hidrocarbonetos aromáticos cíclicos e aldeídos;

- Degradação mais rápida, minimizando consequências ambientais em casos de vazamentos;

- Não há emissão de dióxido de enxofre $\left(\mathrm{SO}_{2}\right)$;

- Ponto de fulgor elevado $\left(>100^{\circ} \mathrm{C}\right)$, o que the garante menores riscos quanto a sua flamabilidade;

- Apresenta excelentes propriedades de lubrificação;

- É miscível com o diesel qualquer que seja a proporção.

Contudo, quando comparado ao óleo diesel, o biocombustível não é isento de desvantagens e possui também pontos fracos, conforme listado abaixo [25]:

- Capacidade de produção ainda insuficiente para suprir a demanda de uma eventual substituição integral do combustível fóssil; 
- Consumo de combustível ligeiramente superior devido ao menor poder calorífico;

- Emissões de óxidos nitrosos $\left(\mathrm{NO}_{\mathrm{x}}\right)$ sensivelmente mais elevadas;

- Maior ponto de fusão, que se traduz como um inconveniente em lugares sujeitos a baixa temperatura;

- O armazenamento de longa duração (tempo superior a seis meses) não é recomendado, em razão de sua menor estabilidade.

Vale destacar também que a formação de misturas diesel/biodiesel pode funcionar como uma ferramenta capaz de auxiliar na suavização de fragilidades do biodiesel. Além disto, pode-se dizer que difundir a utilização de misturas diesel/biodiesel significa viabilizar substituições parciais da demanda do combustível fóssil pelo biocombustível, reduzir emissões de gases do efeito estufa e aliviar o volume de óleo diesel necessário a ser importado.

No Brasil, desde 2008, a introdução gradual do biodiesel misturado ao óleo diesel tornou-se obrigatória. Inicialmente, a proporção exigida foi de $2 \%$ (em volume) de biodiesel. Ao longo dos anos a participação percentual do biocombustível misturado ao diesel cresceu e, desde novembro de 2014, a quantidade de biodiesel na mistura é de $7 \%$ em volume. A Lei $n^{\circ} 13.263$, de 23 de março de 2016, estipula aumentos para 8\%, 9\% e 10\% de biodiesel misturado ao diesel em 12, 24 e 36 meses, respectivamente. Ainda neste contexto, a Resolução $\mathrm{n}^{\circ} 3$ do Conselho Nacional de Política Energética autorizou, em 21 de setembro de 2015, 20\% de biodiesel (em volume) misturado ao diesel para frotas cativas ou consumidores rodoviários atendidos por pontos de abastecimento e até $30 \%$ de biodiesel (em volume) misturado ao diesel empregado no transporte ferroviário e uso agrícola.

No Anexo C, apresenta-se a caracterização do biodiesel utilizado nesta dissertação. Enquanto no Apêndice $A$, disponibilizam-se valores médios de massa específica e poder calorífico inferior do biodiesel em função das duas principais matérias-primas para o biocombustível brasileiro atualmente (soja e sebo bovino), segundo informações coletadas por Pradelle [14] e disponibilizadas em sua tese de doutorado.

\section{2}

\section{Etanol e os Motores de Ignição por Compressão}

Tipicamente, pode-se dizer que a utilização de biocombustíveis apresenta atrativos potencialmente relevantes. Estes combustíveis, produzidos através da biomassa, constituem fontes de energia renováveis e possuem ciclos produtivos 
que contribuem bem menos para o aquecimento global do que os combustíveis fósseis. Além disto, o desenvolvimento de uma cadeia produtiva consistente de biocombustíveis é capaz de estimular a independência energética nos países [27]. Especialmente para os motores de ignição por compressão, é possível eleger-se o biodiesel e o etanol como biocombustíveis promissores.

Misturas diesel/biodiesel já são atualmente aplicadas em veículos comerciais, proporcionando vantagens ambientais e energéticas. Com propriedades similares ao combustível fóssil tradicional, o biodiesel mostra-se eficaz em substituir o diesel ao mesmo tempo em que garante reduções substanciais nas emissões de material particulado (PM) e de monóxido de carbono (CO) ([28] e [29]).

Contudo, a produção de biodiesel ainda não é suficiente para suprir a demanda de uma hipotética substituição integral do diesel pelo referido combustível renovável. Por isso, dentre os combustíveis renováveis, o etanol também desponta como uma boa alternativa de biocombustível, dada a sua disponibilidade em larga escala [30]. Não obstante, existem limitações quanto à proporção de etanol misturado ao diesel devido à diferença de polaridade entre os álcoois e os hidrocarbonetos do óleo diesel.

Ultimamente, pesquisas relacionadas aos biocombustíveis nos motores de ignição por compressão têm procurado o melhor aproveitamento destes combustíveis aliando a menor emissão de poluentes a desempenhos eficientes dos $\mathrm{MCl}$, conforme já exposto no capítulo introdutório desta dissertação. A Lei $\mathrm{n}^{\circ}$ 12.490 , de 16 de setembro de 2011, reforça o fomento à pesquisa e ao desenvolvimento relacionado ao uso de biocombustíveis na mitigação da emissão de gases associados ao efeito estufa e poluentes.

Os métodos que têm sido estudados a fim de minimizar-se o emprego do diesel nos motores de ignição por compressão vão desde substituições parciais até as substituições totais. A maior parte dos métodos consiste em substituições parciais da queima de óleo diesel em motor de ignição por compressão: misturas etanol/diesel, emulsões etanol/diesel, injeção do etanol no coletor de admissão ("fumigação") e jato piloto diesel na câmara de combustão, ou ainda injeção direta de etanol e diesel na câmara de combustão. Já a substituição total do diesel pode ser obtida pela conversão do motor ciclo Diesel para o ciclo Otto ("ottolização") ou pela utilização de etanol e aditivos melhoradores de ignição.

Ao longo deste trecho da revisão bibliográfica serão apresentadas algumas características básicas do etanol, bem como estratégias relevantes na substituição parcial ou integral do diesel nos motores de ignição por compressão, 
permitindo-se a abordagem de fundamentos necessários à estruturação deste trabalho. Portanto, para melhor organizar o conteúdo a ser estudado é possível listar os métodos mais utilizados na queima de etanol em motores de ignição por compressão, conforme sugeriu Egúsquiza [31] em sua tese de doutorado:

- Substituição parcial por meio de misturas etanol/diesel;

- Substituição parcial através de misturas etanol/diesel com aditivos estabilizadores;

- Substituição parcial por dois métodos distintos de injeção dual-fuel: injeção indireta do combustível substituto ("fumigação") ou dupla injeção direta dos combustíveis na câmara de combustão;

- Substituição total por meio da conversão do motor ciclo Diesel convencional em ciclo Otto ("ottolização");

- Substituição total por meio de aditivos melhoradores da autoignição no etanol que, além de aumentar o número de cetano, também possuam propriedades lubrificantes e inibidoras de corrosão.

\subsection{1}

Etanol

O etanol $\left(\mathrm{C}_{2} \mathrm{H}_{5} \mathrm{OH}\right)$ é um álcool de cadeia carbônica pequena que pode ser obtido através de processamento químico, ou mais comumente a partir da fermentação de sacarose (e.g.: cana-de-açúcar, sorgo e beterraba), assim como de amidos (e.g.: milho, mandioca, trigo, batata e arroz). Porém, a obtenção via fermentação do amido precisa passar por mais transformações para a geração do etanol, já que o amido é um carboidrato de considerável complexidade [32].

O álcool etanol caracteriza-se como um combustível incolor, volátil, inflamável e totalmente solúvel em água. No Brasil, existem basicamente dois tipos de etanol oficialmente regulamentados: etanol anidro e etanol hidratado. $\mathrm{O}$ etanol anidro é praticamente ausente de água, com uma porcentagem de álcool em massa de no mínimo 99,3\% [33]. Já no etanol hidratado, que permite uma quantidade diluída de água ligeiramente maior, a porcentagem de álcool em massa deve estar entre $92,6 \%$ e 93,8\% [34]. O combustível é extensivamente empregado em sua forma hidratada, ou misturado à gasolina e pode ser até mesmo misturado ao diesel quando em sua forma anidro.

A Figura 8 do trabalho de Hardenberg et al. [35] mostra a viabilidade teórica do etanol substituir o diesel em termos de eficiência, ou seja, sob as mesmas condições de operação de um motor de ignição por compressão $(\mathrm{Cl})$ movido a diesel, o motor $\mathrm{Cl}$ movido a etanol apresenta resultados parecidos e 
até uma eficiência ligeiramente maior.

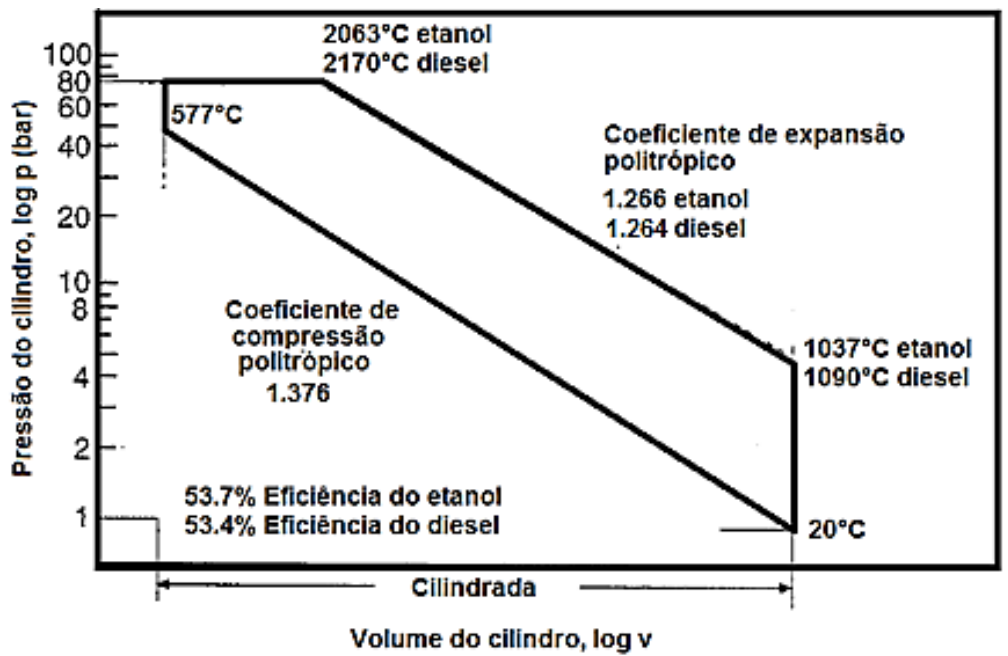

Figura 8 - Comparação de motor $\mathrm{Cl}$ movido a diesel e etanol

Os álcoois, mais especificamente o etanol devido à toxidade do metanol, apresentam-se como vantajosos combustíveis em alternativa ao óleo diesel na redução da emissão de poluentes. Os álcoois contém oxigênio em sua molécula, são combustíveis muito voláteis e também permitem a adição de água em sua composição, então todas essas características contribuem bastante para uma boa combustão. Aliado a isso, também pode-se considerar a menor presença de carbono nos álcoois, o que favorece uma emissão quase inexistente de material particulado, bem como a emissão de dióxido de carbono no ciclo completo de etanol (produção/utilização) que também pode ser dada como nula [31].

O etanol é um combustível que pode ser usado em motores de ignição por centelha sem maiores dificuldades. Por outro lado, apesar de suas vantagens, principalmente, em termos de emissões, há obstáculos na utilização do etanol em motores $\mathrm{Cl}$ que têm encorajado as pesquisas nesta área. Algumas características relevantes do etanol que limitam sua utilização no motor $\mathrm{Cl}$ são: baixo índice de cetano do etanol, o que dificulta sua autoignição e implica em longos atrasos da ignição, assim como baixos poder calorífico e lubricidade quando comparados com essas propriedades do óleo diesel [36]. Para os fins de pesquisa dos testes desta dissertação utilizou-se o etanol anidro, o qual possui algumas de suas propriedades mais importantes apresentadas no Apêndice A, de acordo com informações disponibilizadas na dissertação de Ferrari Filho [24].

Apesar do viés renovável e ecologicamente mais amigável quando comparado a combustíveis fósseis como diesel, o etanol possui algumas características limitadoras que precisam ser levadas em conta nos projetos de motores que operem com este combustível, a fim de que se promova a 
prevenção de danos aos componentes mecânicos e viabilize-se sempre a combustão mais completa possível. As referidas observações e cuidados sobre o uso do etanol apresentam-se abaixo, conforme a dissertação de Bambrila [22]:

- Baixo poder calorífico do etanol comparado ao diesel, levando ao maior consumo de etanol para fornecer a mesma quantidade de energia entregue pelo combustível diesel. Esta característica é ainda mais marcante pelo fato de o etanol ser um fluido higroscópico, absorvendo água com facilidade e potencializando os efeitos do baixo poder calorífico;

- Elevada acidez do etanol, em virtude da presença de água e ácidos, aumentando a possibilidade de corrosão e exigindo tratamentos superficiais em componentes que estejam em contato direto com o combustível como forma de prevenção;

- Possibilidade de contaminação/ressecamento de borrachas por solvente, que por vezes podem requisitar a troca do componente devido à danificação por produtos químicos.

\subsection{2}

\section{Injeção Dual-Fuel}

$\mathrm{Na}$ busca pela substituição do óleo diesel em motores de ignição por compressão, começaram a surgir na década de 1950 pesquisas que aliassem à injeção do diesel, injeções de outros combustíveis visando-se à substituição do diesel, assim como a redução das emissões de fumaça dos motores de ignição por compressão do tipo convencional [37].

As estratégias de injeção dual-fuel se revelam como promissoras ferramentas na busca de motores de ignição por compressão de altas eficiências e baixas emissões de $\mathrm{NO}_{\mathrm{x}}$ e fuligem. A natureza pobre do processo de combustão das estratégias deste tipo garante a alta eficiência térmica, devido às reduzidas perdas por transferência de calor das combustões com picos de temperatura amenizados. Após anos de amadurecimento no campo das pesquisas sobre o método no qual dois combustíveis com diferentes características de autoignição são misturados no interior do cilindro, Bessonette et al. [38] apontam a abordagem da diferença de reatividade dentro do cilindro como uma estratégia eficaz de lidar com combustões dual-fuel. Nesta mesma linha de pesquisa de Bessonette, Inagaki et al. [39] mostram que não somente a razão de equivalência, mas também a estratificação da reatividade do combustível contribui para taxas de liberação de calor menores e ruídos dentro dos padrões aceitáveis [40]. 
Kokjohn et al. [41], que fazem parte de um grupo de pesquisas da universidade norte americana de Wisconsin-Madison, tem se empenhado ultimamente no estudo da referida estratégia de combustão e chegaram a batizala com o nome Reactivity Controlled Compression Ignition (RCCl). Inicialmente Kokjohn et al. [41] propuseram o $\mathrm{RCCl}$ operando a partir da injeção indireta (PFI), vide Figura 9 [42], de um combustível de baixo número de cetano, promovendo uma carga bem misturada de combustível de baixa reatividade, ar e em alguns casos gases advindos de sistemas de recirculação EGR. Já o outro combustível, de alto número de cetano (alta reatividade), deveria ser injetado diretamente por meio de injeções simples ou múltiplas durante o curso de compressão. No motor $\mathrm{RCCl}$, enquanto a fase da combustão é controlada pela razão relativa dos combustíveis utilizados, o controle da duração da combustão é dado pela estratificação espacial entre eles [43].

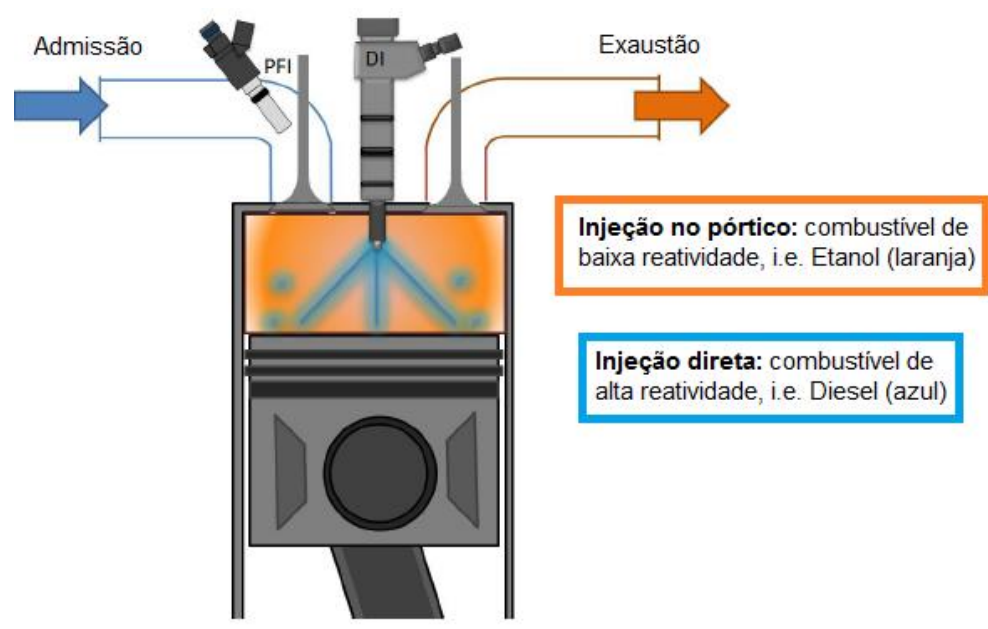

Figura 9 - Estratégia dual-fuel com "fumigação"

Tipicamente utilizada como combustível de baixa reatividade na combustão $\mathrm{RCCl}$, a gasolina não consome tanta energia em sua mudança de fase líquidagasosa, o que faz com que a sua injeção indireta ou direta no começo do ciclo de compressão não imponha impactos significativos à pressão e à temperatura ao final do ciclo de compressão. Por outro lado, de acordo com Asad et al. [44] e reforçado pelos testes da tese de Egúsquiza [31], a alta entalpia de vaporização e o baixo ponto de vaporização do etanol (mais volátil que a gasolina) contribuem para redução dos picos de pressões e temperaturas ao final da etapa de compressão. Curran et al. [45] ainda complementam lembrando que a reatividade do etanol é menor que a da gasolina devido ao baixo número de cetano deste, o que gera um gradiente de reatividade mais amplo nos 
processos. Além disto, estes autores afirmam que a combinação de gradientes mais acentuados de reatividades entre os combustíveis e o efeito de resfriamento da carga admitida possibilita uma faixa de carga maior para aplicação RCCl.

Asad et al. [44] evidenciaram através de testes experimentais, vide Figura 10, que variando-se a fração de etanol (EF) entre 1/3 e 2/3 via injeção indireta e quantificada em termos de energia do combustível injetado, houve queda na pressão em aproximadamente 8 bar e reduções de temperatura da ordem de $100 \mathrm{~K}$ ao final do ciclo de compressão.

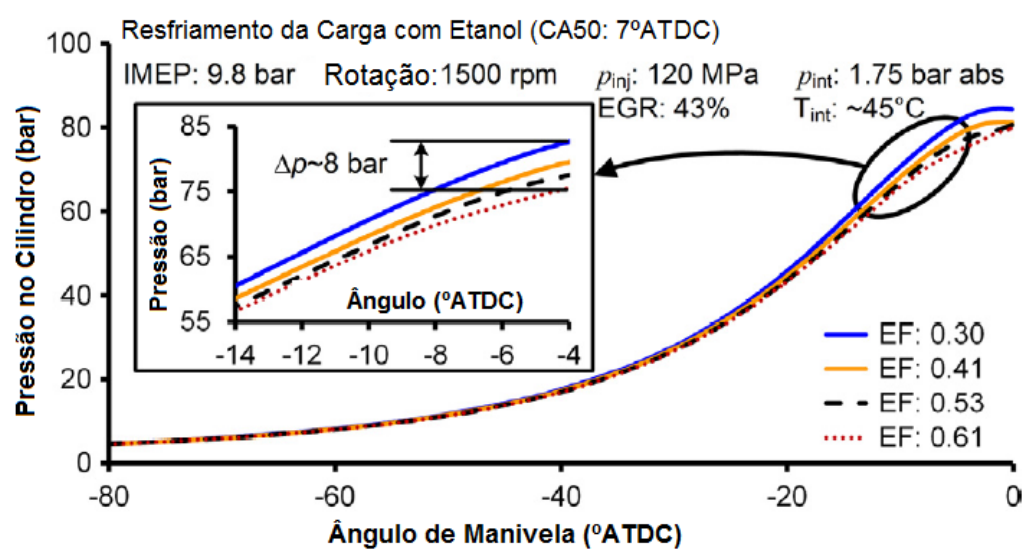

Figura 10 - Efeitos da Injeção de Diferentes Frações de Etanol

Splitter et al. [46] comentam em seu artigo que a extensão da duração da combustão $\mathrm{RCCl}$ com etanol acontece graças à combinação de fatores como: temperatura, diferenças nas reatividades local e global, bem como diferenças químicas na mistura etanol-diesel. Sarjovaara et al. [47] confirmam isto, mostrando que a redução na temperatura da carga admitida conduzia a uma tendência de atraso e redução no pico da taxa de liberação de calor. Estes autores ainda apontam a temperatura de admissão da carga e a razão de etanol injetada como fatores mais relevantes do que o atraso da ignição ou a combustão do combustível diesel, ao avaliar-se a frente de chama da combustão do etanol após a combustão principal de diesel.

O estudo de Benajes et al. [48] constatou, em termos de emissões, que o uso de etanol pode caracterizar níveis de $\mathrm{HC}$ e $\mathrm{CO}$ ligeiramente maiores em situações de média e alta carga para as misturas avaliadas com maior percentual de etanol (E85), ao passo que as emissões de $\mathrm{NO}_{x}$ são reduzidas. Já a formação de fuligem pode ser inibida em cargas baixas pela estratégia de avanço da injeção do combustível de alta reatividade e nas cargas médias e altas pelo controle da fração de etanol utilizada no processo de combustão. 
Logo, apesar de apresentar algumas vantagens particulares, o método $\mathrm{RCCl}$ sofre com os níveis de $\mathrm{HC}$ e $\mathrm{CO}$ mais elevados quando comparados ao tradicional CDC [49]. Isto ocorre principalmente pelas temperaturas mais baixas envolvidas no processo que impossibilitam a completa oxidação do combustível, além das eventuais deposições. Já existem pesquisas que procuram minimizar estas desvantagens. Há, inclusive, um trabalho recente de Wissink et al. [50] que aponta a injeção direta de ambos combustíveis como forma de diminuir emissões de HC pelo controle mais eficiente da vazão do combustível de baixa reatividade, permitindo também maior controle no atraso da ignição [49]. A técnica de injetar ambos os combustíveis diretamente na câmara de combustão desponta não somente pela capacidade em amenizar emissões, mas também por permitir taxas de substituição energética da ordem de $90 \%$ em situação de plena carga e entre $60 \%$ e $80 \%$ em condições de carga parcial [51].

No entanto, a complexidade e a onerosidade de um segundo sistema de injeção direta para o etanol configuram como empecilhos à livre difusão do método em motores de ignição por compressão. A disponibilidade de espaço físico no cabeçote para a instalação dos dois injetores sem que ocorram obstruções nos pórticos de admissão e exaustão ainda é um desafio para a dupla injeção direta. No trabalho de Kolodziej et al. [52] as dificuldades em implementar modificações necessárias no cabeçote para a acomodação dos injetores (Figura 11) foram contornadas mais facilmente, visto que os testes realizaram-se em um motor monocilíndrico de grande porte (heavy-duty).

A gama de material e informação disponível a cerca da técnica $\mathrm{RCCl}$ tem crescido e encorajado novas pesquisas sobre o assunto. Tanto que 0 artigo de Reitz e Duraisamy [53] traz um atualizado apanhado de muitos aspectos importantes do método dual-fuel $\mathrm{RCCl}$ abordados ultimamente. 


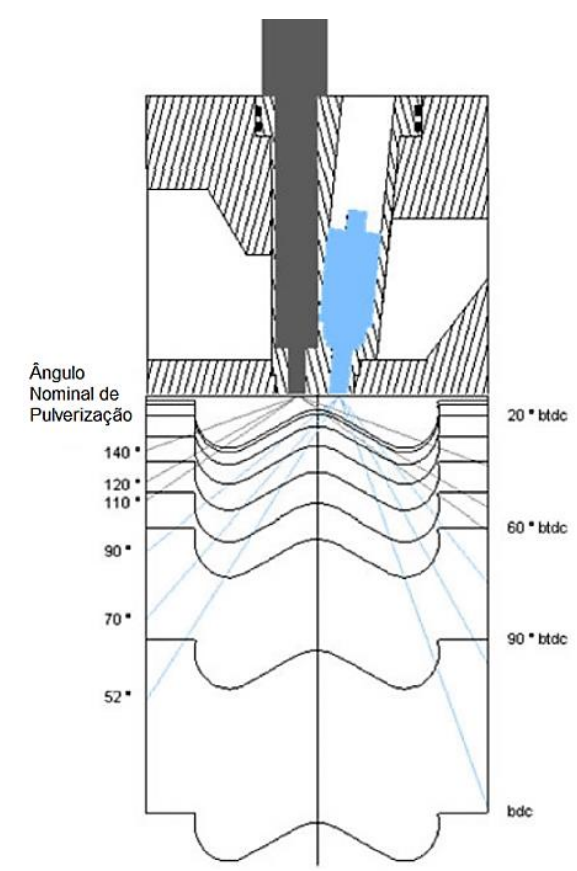

Figura 11 - Posicionamento da dupla injeção direta no cabeçote [54]

\subsection{3 \\ Melhoradores da Autoignição}

A substituição integral do óleo diesel como combustível em motores de ignição por compressão pode ser alcançada pela mistura em quantidades limitadas (entre 5\% a 20\%) de aditivos melhoradores de ignição ao etanol. Muitas vezes a utilização de ativadores de ignição não exige modificações complexas nas configurações do motor, mas é possível que existam situações em que a quantidade requerida de aditivo possa limitar a sua aplicação e, por isso, adaptações sejam necessárias. Nestas situações, pode-se alternativamente sugerir o aumento da razão de compressão ou o aquecimento do ar admitido a fim de que não somente os aditivos no combustível venham a favorecer a autoignição, mas que também as condições na câmara sejam propícias [55].

O grande destaque nos estudos sobre o etanol com aditivos é a busca por substâncias capazes de aumentar as propriedades cetânicas do etanol em prol da autoignição da carga no interior do cilindro com razões de compressão típicas de motores diesel convencionais. Originalmente, os aditivos formavam-se em sua grande maioria por combinações de nitratos, peróxidos e nitritos. Estas substâncias exigem manipulações complexas e cuidadosas, pois, especialmente devido às características físico-químicas dos nitratos, há riscos à saúde humana (efeitos vasodilatadores agressivos) pela inalação de vapores tóxicos [56].

Hardenberg e Schaefer [57] testaram, em 1981, um motor diesel 
convencional de injeção direta e razão de compressão 17:1 com uma mistura de $88 \%$ etanol hidratado (95\% v/v de etanol) e $12 \%$ de um melhorador de autoignição composto por hexil-nitrato. Os testes, executados à plena carga, avaliaram todas as faixas de rotação do motor. Os resultados mostraram melhores rendimentos térmicos com etanol aditivado nas operações com rotações abaixo dos $80 \%$ do valor máximo. Já os números das emissões indicaram que entre $40 \%$ e $100 \%$ da rotação máxima os $\mathrm{HC}$ e $\mathrm{NO}_{x}$ foram amenizados com o uso do etanol aditivado, mas por outro lado nas rotações abaixo dos $40 \%$ os $\mathrm{NO}_{x}$ se mostraram maiores do que no funcionamento com diesel convencional. Outro aspecto analisado pelos autores foi a contribuição para as emissões de $\mathrm{NO}_{x}$ da decomposição do aditivo nitrogenado na combustão, em que foi constatado que os níveis das emissões foram inferiores aos previstos pela completa decomposição do melhorador. Por isso, os autores puderam depreender que o nitrogênio que compõe o aditivo (na forma de nitrato) é liberado como $\mathrm{N}_{2}$ e seu oxigênio utilizado como comburente na combustão.

Felizmente já existe uma nova geração de aditivos sem nitratos, que se desenvolveu mais recentemente, possibilitando grandes avanços em termos da viabilidade de manipulação com menor potencial de danos à saúde e maior facilidade de prevenção dos riscos em seu transporte. Dentre os aditivos melhoradores mais recentes, destacam-se aqueles baseados na utilização da substância química conhecida por polietilenoglicol (PEG), a qual é sintetizada pela reação de polimerização do óxido de etileno. Além de suas vantagens no tocante à sua manipulação, o PEG também possui propriedades lubrificantes que o tornam interessante para o sistema de injeção do motor. As desvantagens do PEG ficam por conta da menor influência desta substância no aumento do número de cetano do etanol quando comparada aos aditivos que utilizam nitrato e também por sua elevada flamabilidade, restringindo-o ao uso controlado no Brasil por medidas de segurança, mesmo que seus efeitos tóxicos sejam bem mais brandos. Alternativamente aos PEGs, Sánchez [58] sugere em sua tese de doutorado a utilização de misturas de etanol hidratado com concentrações de $10 \%$ e $15 \%$ de n-butanol como aditivo.

Há alguns anos um projeto global de disseminação da técnica de utilização de aditivos melhoradores da autoignição em etanol, coordenado pela Prefeitura de Estocolmo na Suécia, foi posto em prática em 2006 e teve duração de alguns anos. O projeto incentivado pela União Europeia e denominado BEST (BioEthanol for Sustainable Transportation - BioEtanol para Transporte Sustentável) almejou, além de difundir a referida estratégia, testar o etanol 
aditivado em veículos de transporte público em nove cidades ao redor do mundo. São Paulo foi a cidade brasileira participante deste projeto, o qual foi viabilizado no Brasil por um grande conglomerado de parcerias entre empresas. A Scania Latin America garantiu a importação do chassi e do motor da Suécia, a Marcopolo fez o projeto, a construção e o fornecimento da carroceria, a UNICA (União da Indústria de Cana-de-Açúcar) forneceu o etanol para os testes, a BAFF/SEKAB disponibilizou o aditivo de fabricação própria a ser adicionado ao etanol, enquanto a Petrobrás realizou a importação dos aditivos [59].

Geralmente, os maiores desafios na utilização dos aditivos melhoradores de autoignição do etanol não estão no âmbito de questões técnicas ou operacionais, mas sim em assuntos relacionados aos custos logísticos das substâncias, que muitas vezes são importadas, e ao preço de mercado dos aditivos, os quais costumam ser aplicados em maiores concentrações quando comparado aos aditivos estabilizadores de misturas etanol/diesel.

\subsection{4 \\ Conversão de Ciclo Diesel em Ciclo Otto (“Ottolização")}

A chamada "ottolização" é uma técnica que também permite a substituição integral do diesel por álcoois através da ignição por centelha destes em motores originalmente de ignição por compressão, aproveitando-se ainda de características dos álcoois que possam ser vantajosas em ignições por centelha, tais como: alto calor latente de vaporização e baixos números de cetano. Diferentemente do que acontece nos motores de ignição por compressão, o clássico parâmetro de atraso da ignição torna-se um valor sem muito significado na ignição por centelha de um motor "ottolizado" [60].

A ideia do procedimento de "ottolização" é simples: transformar, através de adaptações, um motor que opere originalmente um ciclo diesel convencional em um motor de ignição por centelha que utilize etanol como combustível. Para isto, geralmente, o sistema original de injeção diesel é substituído por válvulas injetoras ou ainda por dispositivos de carburação e, em alguns casos, é necessária a escavação para redimensionar a superfície do pistão, buscando-se o efeito de reduzir razões de compressão que sejam demasiadamente elevadas na utilização dos álcoois em motores de ignição por centelha [56]. Além disto, para a ignição por centelha, é necessária a instalação de uma vela na câmara de combustão e todos os componentes associados ao sistema de ignição.

Em 1980 Adelman e Pefley [71] realizaram testes com etanol e metanol considerando a "ottolização" de um motor diesel convencional, monocilíndrico, 
com injeção indireta e razão de compressão 19:1. Testados separadamente, os álcoois foram injetados quando o pistão se encontrava na posição de $35^{\circ} \mathrm{CA}$ antes do ponto morto superior (BTDC) e a centelha da vela configurada para a posição de $5^{\circ}$ BTDC. Quanto à metodologia de injeção, o intervalo de injeção precisou ser acrescido em $10^{\circ}$ além do requerido pelo diesel (haja vista o poder calorífico reduzido dos álcoois) e a posição do avanço da ignição foi limitada pela combustão detonante. Os resultados, à rotação de 900 RPM, indicaram que em baixas cargas do motor a operação com diesel apresentou melhor eficiência térmica, enquanto que em altas cargas ambos os álcoois forneceram maiores rendimentos. Os autores também revelaram que as emissões de $\mathrm{HC}$ e $\mathrm{CO}$ se mostraram mais elevadas no motor "ottolizado" quando comparadas ao diesel, o que, segundo eles, deve-se principalmente às características do tipo de combustão em motor convertido. Enquanto as combustões de diesel convencionais acontecem em vários pontos da câmara de combustão, as combustões dos motores "ottolizados" movidos a etanol possivelmente ocorrem em um único ponto (nas extremidades dos eletrodos), resultando em tendências de queima incompleta da carga em algumas regiões do interior do cilindro. Já as análises das emissões de $\mathrm{NO}_{x}$ apontaram valores entre $30 \%$ e $40 \%$ inferiores ao modo diesel convencional, o que pode ser justificado pela presença de menores picos de temperatura da chama em razão do alto calor latente dos álcoois. Por último, as emissões de material particulado no motor "ottolizado" foram praticamente nulas, acompanhando a tendência das emissões de $\mathrm{NO}_{\mathrm{x}}$.

Todavia, o procedimento de "ottolização" também enfrenta alguns desafios semelhantes aos abordados na estratégia de dupla injeção direta de etanol e diesel. O processo de "ottolização" exige uma série de adaptações no motor original, exigindo disponibilidade de espaço principalmente no cabeçote do motor, onde não somente a vela de ignição possa ser instalada, mas também que a posição selecionada permita um arrefecimento apropriado do eletrodo.

\subsection{5}

\section{Misturas Etanol/Diesel}

As primeiras pesquisas no âmbito da utilização de misturas etanol/diesel em motores de ignição por compressão têm seu início datado na década de 1970 na África do Sul e logo em seguida, na década de 1980, nos Estados Unidos e na Alemanha [72].

A partir de então se desenvolveram diversos experimentos de laboratório e de campo utilizando misturas de etanol e diesel com diferentes concentrações de 
etanol anidro até um limite de $30 \%$ em proporção de volume $(30 \% \mathrm{v} / \mathrm{v})$. As experiências de Strait et al. [73] testaram dois motores de ignição por compressão de injeção direta, naturalmente aspirados e com razão de compressão de 16,8:1 provenientes da propulsão de tratores e máquinas agrícolas. Os resultados obtidos nos testes, que não fizeram qualquer alteração no sistema de injeção dos motores, revelaram que as máximas potências foram reduzidas quando os motores operavam com as misturas. Já quanto ao consumo específico, intensidade de ruído e atraso da ignição se observou comparativamente aos valores do funcionamento com óleo diesel puro - o aumento dos parâmetros à medida que a proporção de etanol na mistura foi incrementada.

Meiring et al. [74] realizaram testes com uma mistura contendo $15 \%$ de etanol anidro sem aditivos, com a intenção de avaliar o desempenho e a durabilidade de motores de tratores agrícolas. Os autores constataram uma pequena redução no desempenho do motor operando com a mistura contendo etanol, mas por outro lado não houve deterioração significativa do motor ou mesmo do sistema de injeção após mil horas de testes.

O procedimento de misturar etanol ao diesel sem o uso de qualquer aditivo é o procedimento mais simples em que se substitui parcialmente a utilização do combustível fóssil por uma fonte alternativa renovável e menos poluente em motores de ignição por compressão. Conforme já reportado, a presença de etanol na mistura ocasiona acréscimos no atraso na ignição e reduz o poder calorífico da mistura. Então, a simplicidade da técnica se justifica pela pequena quantidade de ajustes sem maior complexidade para que se atinja, com o uso do combustível misturado, a mesma potência obtida com a utilização de diesel. Geralmente leves ajustes no avanço da injeção e na quantidade de combustível injetado são suficientes, aproximando o desempenho do motor nas condições de mistura etanol/diesel e apenas diesel [60].

Porém há restrições no uso de misturas etanol/diesel, porque, ao contrário da combinação etanol/gasolina que forma misturas homogêneas em todas as proporções, a miscibilidade entre diesel e etanol é mais limitada. Além da questão da miscibilidade, a adição do etanol ao diesel também modifica outras propriedades como a viscosidade, lubricidade, poder calorífico e o número de cetano [75]. Portanto a técnica de mistura direta de etanol/diesel fica restrita a baixas concentrações de etanol, tipicamente não mais do que $20 \%$ em proporção de volume (v/v), para que se evite a tendência de separação de fases entre os combustíveis ([60] e [76]). Ainda existem outros fatores que podem 
potencialmente aumentar a tendência de separação de fase dos combustíveis: maior presença de água na composição do etanol (caso do etanol hidratado brasileiro), diminuição da temperatura, composição do diesel, além do já mencionado aumento da concentração de etanol na mistura [77].

\subsection{6}

\section{Misturas Etanol/Diesel com Aditivos Estabilizadores}

Diferenciando-se da técnica de mistura etanol/diesel pela utilização de aditivos especiais, as misturas etanol/diesel com a adição de agentes emulsificantes (surfactantes) ou co-solventes (e.g.: biodiesel) podem, através de micro emulsões ou soluções homogêneas estáveis [78], substituir até $40 \%$ do uso de diesel sem que se comprometa grande parte das vantagens e características associadas às misturas [31].

Estes aditivos estabilizadores são acrescentados às tradicionais misturas em uma quantidade que depende do tipo de etanol e das propriedades físicoquímicas do diesel, porém sempre com o intuito de aumentar a estabilidade, garantindo mais constância e homogeneidade à mistura. Tipicamente, os surfactantes/co-solventes além de permitirem reduções da temperatura de operação, também melhoraram a tolerância das misturas à presença de água, viabilizando a utilização de álcoois hidratados nas misturas.

Basicamente, há dois tipos de abordagens para a estabilização de misturas através de aditivos: a aplicação de surfactantes (ou emulsificantes) que produzam emulsões (ou microemulsões) estáveis, ou a introdução de cosolventes para a obtenção de soluções homogêneas estáveis ([78] e [79]).

Nas microemulsões, gotículas de álcool permanecem espalhadas na fase diesel da mistura, mas para isso é necessária uma pequena quantidade de agente emulsificante e água. A adição de emulsificantes age reduzindo a tensão superficial entre duas ou mais substâncias. Ademais, a preparação de misturas com surfactantes geralmente requer etapas de aquecimento e agitação.

Já os co-solventes atuam como um agente de ligação através da compatibilidade molecular, modificando a capacidade de solvência do solvente puro e permitindo a formação de uma mistura homogênea. A preparação de misturas com co-solventes é mais simples e resume-se em juntar as substâncias envolvidas em um reservatório.

Em ambas as abordagens a quantidade de aditivo necessária é ditada pelo limite inferior de temperatura no qual a mistura em questão deve operar e apresentar-se de forma estável. É importante ressaltar ainda que as duas 
abordagens são frequentemente generalizadas e apresentadas como sinônimos na literatura, todavia neste trabalho o enfoque de homogeneização de misturas baseia-se no uso específico de co-solventes.

Can et al. [80] investigaram as emissões e o desempenho de um motor de ignição por compressão de quatro cilindros, injeção direta, sobrealimentado e com razão de compressão de 21,5:1, na operação com mistura etanol/diesel acrescentados de aditivos estabilizadores. Os testes deste estudo se referem a condições de plena carga em que a pressão de injeção das misturas foi variada entre 150 bar, 200 bar e 250 bar, bem como as concentrações de misturas, que se diferenciavam entre $10 \%$ e $15 \%$ em proporção de volume $(\mathrm{v} / \mathrm{v})$ de etanol anidro e sempre com adição de $1 \%(\mathrm{v} / \mathrm{v})$ de isopropanol para garantir a homogeneidade da mistura. Os resultados mostram que a presença de isopropanol em $1 \%(\mathrm{v} / \mathrm{v})$ é, de fato, eficaz em inibir a separação de fases na mistura. Além disso, os testes também indicaram reduções nas emissões de $\mathrm{CO}$, fumaça e $\mathrm{SO}_{2}$. Por outro lado, houve certo aumento nas emissões de $\mathrm{NO}_{\mathrm{x}} \mathrm{e}$ reduções na potência do motor da ordem de 12,5\% e 20\%, respectivamente para as situações com 10\% e 15\% de adição de etanol, conforme ilustra a Figura 12.

Já os testes de Can et al. [80] sobre a avaliação da pressão de injeção da emulsão indicaram que conforme a pressão foi elevada ocorreram diminuições de $\mathrm{CO}$ e fumaça ao mesmo tempo em que houve aumento nas emissões de $\mathrm{NO}_{\mathrm{x}}$ e redução da potência do motor.
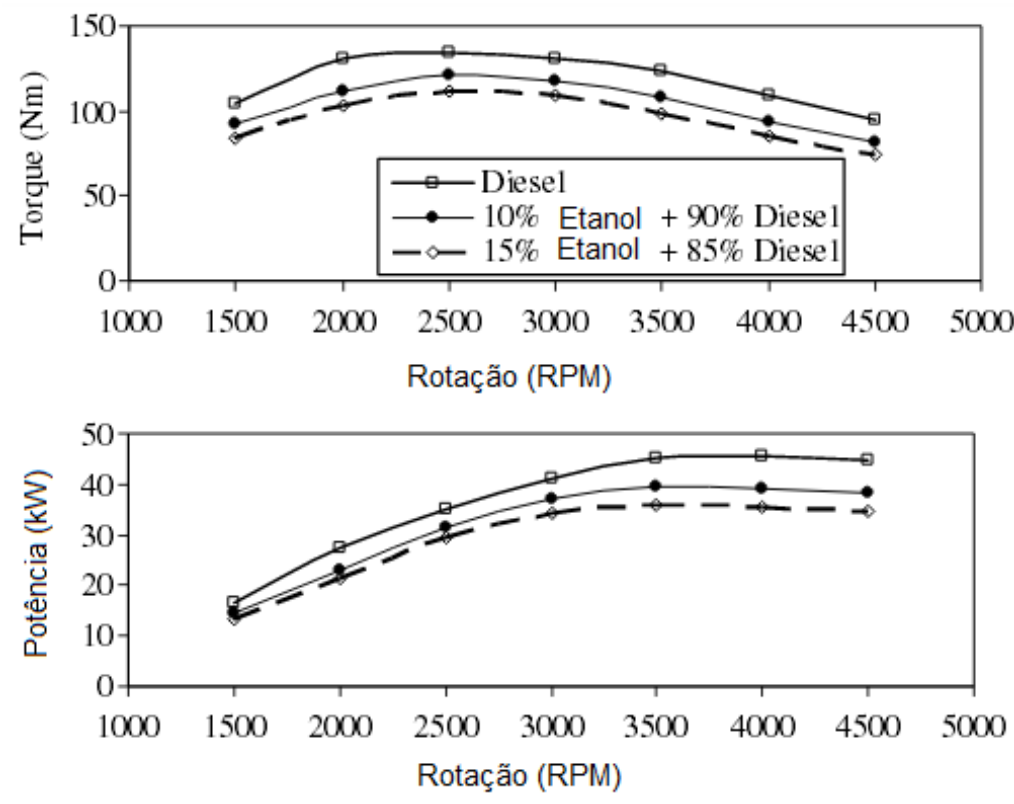

Figura 12 - Torque e potência em misturas etanol/diesel com aditivo 
Os autores apontam que estes aumentos nas emissões de $\mathrm{NO}_{\mathrm{x}}$ e redução na potência estariam relacionados com a grande atomização do spray, o qual não consegue penetrar na câmara de combustão, ficando restrito a uma pequena região próxima ao injetor. Por último, os autores alertam para ocorrência de certo desgaste no sistema de injeção de combustível que pode, possivelmente, ser atribuído à baixa viscosidade e lubricidade do etanol presente nas emulsões.

É de extrema importância que os aditivos surfactantes/co-solvente possuam não somente o caráter de estabilizar a mistura, inerente a sua função específica, mas também a habilidade de garantir a viscosidade adequada para a necessária lubrificação do sistema de injeção ([81] e [82]). Da mesma forma, características inibidoras de corrosão que mantenham as estruturas metálicas mais protegidas da corrosão promovida pela presença da água e propriedades que possam favorecer a autoignição da mistura (aumento do número de cetano ou também redução do calor latente de vaporização) também são fatores relevantes na seleção de um aditivo surfactante/co-solvente.

O biodiesel, apresentado no item 2.1.4, é considerado um co-solvente. Em virtude da similaridade entre suas características físico-químicas com o óleo diesel, este biocombustível, e também co-solvente, pode formar misturas éster/diesel de qualquer proporção e, portanto, é frequentemente utilizado [83]. Além disto, o biodiesel melhora a tolerância à presença de água e é miscível com álcoois, evitando até certo ponto a separação de fases nas misturas etanol/diesel. Com o biodiesel, há também o favorecimento da ignição de misturas etanol/diesel no motor através do aumento do número de cetano e melhoria de propriedades lubrificantes da mistura ([29], [61], [75], [78], [84], [85], [86], [87], [88], [89], [90], [91] e [92]).

Portanto, a aplicação de aditivos estabilizadores em misturas etanol/diesel é um método bem prático que não exige modificações complexas em um projeto de motor de ignição por compressão já existente e encarrega-se de possibilitar a substituição de parcela significativa da participação do diesel pelo etanol mediante a utilização de pequenas concentrações de aditivos na mistura. A seleção de um aditivo específico fica a cargo, então, da melhor combinação entre propriedades e outros parâmetros como, por exemplo: custo financeiro do aditivo, faixa de temperatura para estabilidade da mistura em função das concentrações de seus componentes, caráter renovável, riscos à saúde e ao meio ambiente. 


\section{3 Misturas Diesel/Biodiesel/Etanol (DBE)}

Com o intuito de contornar deficiências das misturas etanol/diesel associadas a sua falta de estabilidade de fase e déficits em propriedades relevantes, a mistura ternária Diesel/Biodiesel/Etanol (DBE) propõe-se a aliar a miscibilidade do biodiesel com o etanol e a semelhança com propriedades do óleo diesel.

Com este artifício, forma-se um combustível que favorece o emprego de fontes de energia renováveis e, ao mesmo tempo, potencializa propriedades benéficas dos componentes da mistura de maneira mais equilibrada. Por exemplo, o ponto de fulgor da mistura ternária DBE tende a ser maior, tornando - armazenamento do combustível mais seguro. Propriedades como a viscosidade, massa específica, lubricidade, poder calorífico e até mesmo o número de cetano podem ser manipuladas com o uso de misturas ternárias DBE com a intenção de que as propriedades desta mistura sejam aptas para uma operação estável em um motor de ignição por compressão ([61], [62], [63], [64], [65], [66], [67], [68], [69] e [70]).

\subsection{1 \\ Miscibilidade de Misturas DBE}

A avaliação da miscibilidade entre os componentes e a homogeneidade das misturas apresenta considerável complexidade em função, principalmente, das características e concentrações das substâncias presentes e do teor de água contido na mistura, bem como da temperatura a qual esta esteja exposta. Os diagramas de fase ternários modelam o comportamento de misturas DBE e auxiliam na estimativa de concentrações limitantes para a estabilidade entre as fases, quando sujeitos à dada temperatura constante.

A utilização do biodiesel tem se destacado ultimamente em razão de sua viabilidade em aumentar a participação de um biocombustível no óleo diesel, fato que se adequa à proposta da União Europeia de encorajar o uso de biocombustíveis nos transportes ([79], [93] e [94]). No entanto, apesar de o biodiesel ser capaz de auxiliar na estabilidade de misturas etanol/diesel por uma vasta extensão do diagrama de fase ternário das substâncias, a completa homogeneização da mistura dependerá das concentrações dos diferentes componentes envolvidos. Portanto, há situações em que somente a aplicação de biodiesel como co-solvente não é suficiente para a garantia da estabilidade 
adequada das misturas etanol/diesel e, por isso, outros tipos de aditivos estabilizadores ainda se façam necessários.

Em 2004, Fernando et al. [84] desenvolveram diagramas de fase ternários para sistemas DBE, utilizando-se diesel com baixo teor de enxofre (menos de 500 ppm de enxofre) e diesel com ultra baixo teor de enxofre (menos de 15 ppm de enxofre). Os autores constataram que nas misturas com menores teores de enxofre, a estabilidade era atingida até em temperaturas mais baixas, assim como também o tipo de etanol influenciava bastante no comportamento das fases no sistema ternário. A Figura 13 descreve o diagrama de fases da mistura ternária composta por diesel norte americano padrão No. 2 com baixo teor de enxofre, etanol anidro e biodiesel (éster metílico de óleo de soja) a $20^{\circ} \mathrm{C}$, que neste caso permanece monofásica para todas as combinações de concentração de seus componentes.

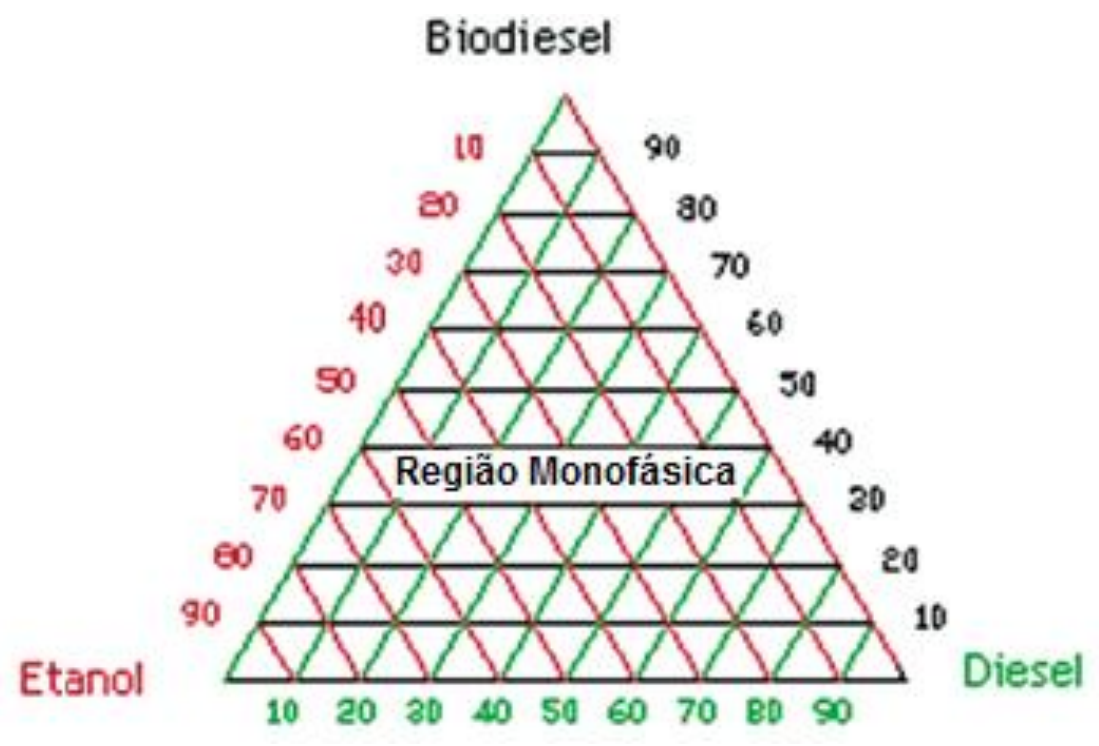

Figura 13 - Concentrações em diagrama de fase ternário

Já Makareviciene et al. [95] estudaram a solubilidade de ésteres metílicos e etílicos de óleo de canola em misturas etanol/diesel para diferentes teores de hidratação do etanol. Os resultados indicaram uma miscibilidade ligeiramente inferior ao utilizar-se éster etílico de óleo de canola, revelando que a miscibilidade também é função da extensão da cadeia carbônica. A Figura 14 mostra que a mistura ternária DBE neste caso nem sempre é miscível. 


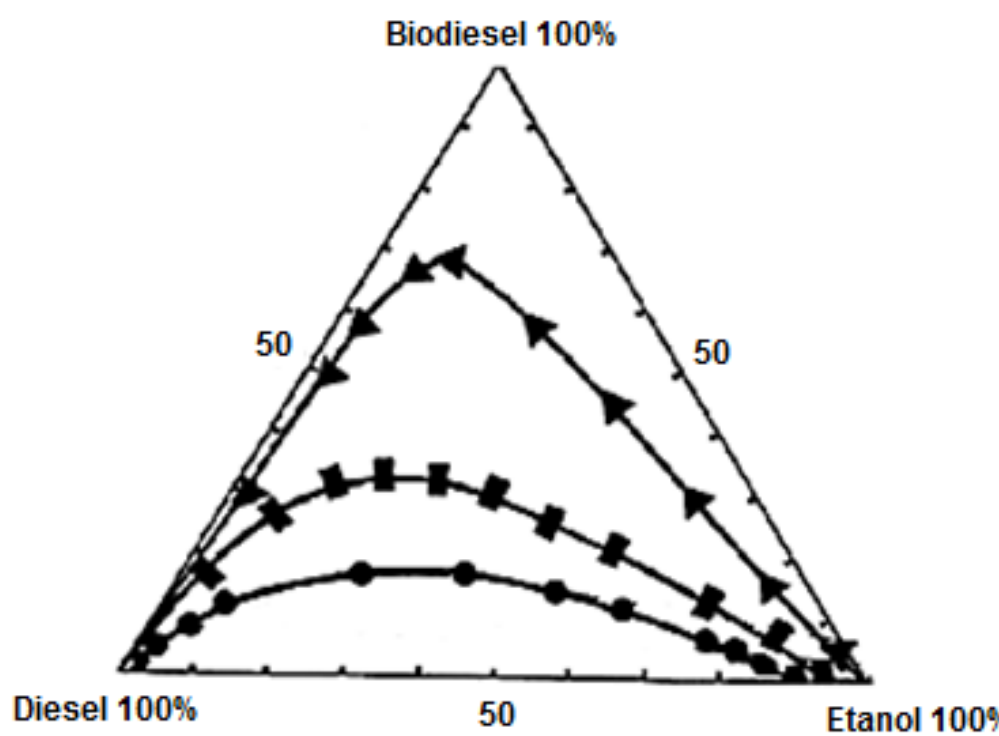

Etanol $[(\bullet) 99.8 \%,(\bullet) 98.5 \%,(\Delta) 94.0 \%]$

Figura 14 - Diagrama de fase ternário para tipos de etanol

Da Figura 14, tem-se que ao avaliar a $20^{\circ} \mathrm{C}$ o uso de etanol com teor de $94 \%$, constatou-se que óleo diesel e etanol não foram miscíveis entre si. No etanol com teor de $98,5 \%$, o limite de miscibilidade do diesel neste etanol foi de $5,4 \%$. Quando o teor do etanol foi elevado para 99,8\%, o limite de miscibilidade do óleo diesel no etanol foi para $8,7 \%$, enquanto $0,9 \%$ de etanol tornaram-se miscíveis ao óleo diesel. Logo, com etanol anidro (teor de 99,8\%) as misturas ternárias estáveis estabeleceram-se por uma ampla faixa de concentração.

Makareviciene et al. [95] também abordaram os efeitos de diferentes temperaturas na solubilidade de misturas DBE e os resultados confirmam as expectativas. A Figura 15 mostra que a miscibilidade entre o óleo diesel e o etanol (com teor de 99,8\%) diminuiu com o decréscimo da temperatura: 8,7\% de diesel foram solúveis em etanol a $20^{\circ} \mathrm{C}$, enquanto apenas $2,9 \%$ a $0^{\circ} \mathrm{C}$. A temperatura de $-10^{\circ} \mathrm{C}$, o campo de misturas estáveis representa menos da metade do tamanho do campo de miscibilidade a $20^{\circ} \mathrm{C}$. Portanto, para a obtenção de soluções estáveis quando a concentração de etanol é maior, fazemse necessários acréscimos na concentração de biodiesel, o que é explicado por seu comportamento como co-solvente que auxilia na estabilização da mistura ternária DBE. 


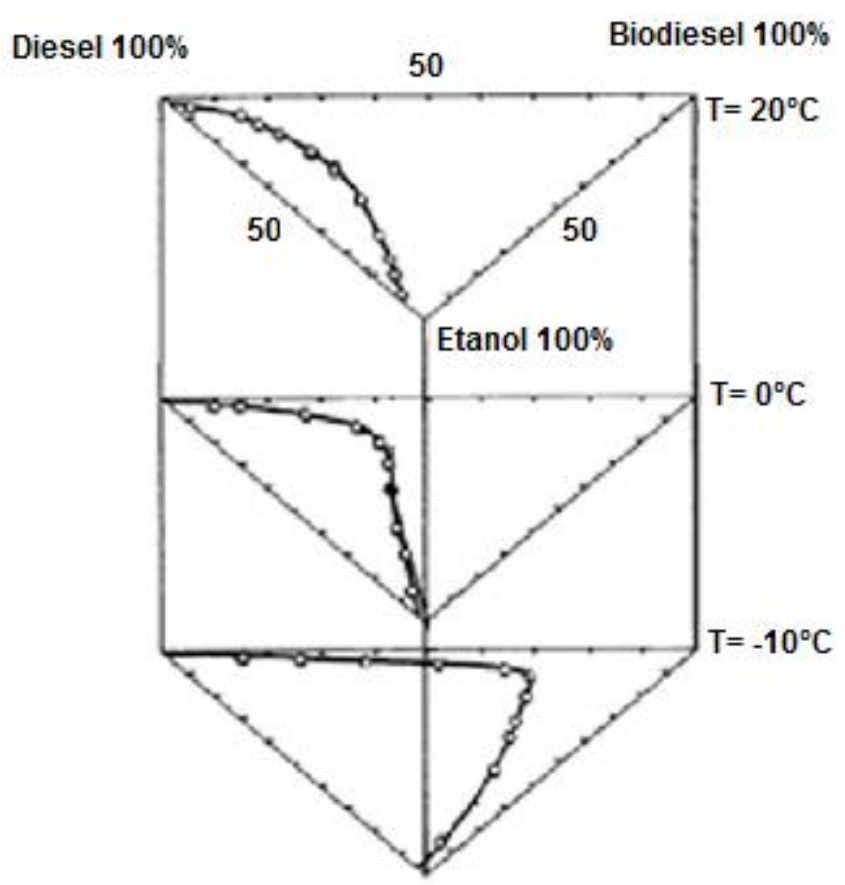

Figura 15 - Planos de temperatura para diagramas de fase ternários

Complementando o que fora explorado por Makareviciene et al. [95], Lapuerta et al. [87], em 2009, também analisaram diagramas de estabilidade de misturas DBE para diferentes temperaturas e concluíram que, de fato, o biodiesel desempenhava um importante papel de componente estabilizador em misturas etanol/diesel, exceto em temperaturas mais baixas quando ocorria a formação de uma fase gelatinosa.

\subsection{2}

\section{Características da Combustão de Misturas DBE}

Sem dúvidas, as características da combustão de misturas DBE são específicas para as inúmeras combinações de concentrações de componentes da mistura que se estabeleçam, no entanto algumas pesquisas já abordaram tendências nas combustões de misturas DBE.

O trabalho de Hulwan et al. [96] encontrou maiores atrasos na ignição e incrementos nas taxas de liberação de calor de misturas DBE em baixas cargas, em virtude do maior calor latente de vaporização e da redução do número de cetano associados à presença do etanol na mistura. Hulwan et al. [96] ainda afirmam que, apesar de um maior atraso da ignição, o término do processo de liberação de calor das misturas DBE pôde ser considerado próximo da avaliação realizada para o combustível diesel. Isto indica um decréscimo na combustão difusiva, justificada pela melhoria no processo de mistura e atomização do 
combustível, bem como pela maior disponibilidade de oxigênio. Esta maior disponibilidade aliada ao atraso da ignição mais prolongado também são motivos para menores emissões de fumaça, de acordo com a análise de Fang et al. [97].

Anteriormente, Ali et al. [98], Park et al. [99] e Qi et al. [100] já haviam notado maiores níveis de mistura do combustível e uma elevada atomização na formação da carga ar/combustível, explicados pela menor viscosidade, tensão superficial e massa específica do etanol. Por conseguinte, estes fenômenos levam a uma queima mais rápida da carga na câmara de combustão.

Kannan [101] realizou testes com uma mistura DBE sob condição de carga de 6,2 bar de BMEP (Pressão Média Efetiva). Nesta investigação, verificou-se a variação do atraso da ignição da mistura em diferentes pressões e instantes de injeção. O autor constatou maiores atrasos na ignição da mistura DBE nas condições relacionadas aos instantes e pressões das injeções avaliadas, comparativamente ao combustível diesel.

Já em 2012 Park et al. [102] avaliaram a influência da concentração de biodiesel na combustão da mistura DBE e afirmou que o atraso da ignição abrevia-se quanto maior é a proporção entre biodiesel e etanol na mistura DBE. Ainda neste artigo, Park et al. [102] observaram que o atraso da ignição cresceu significativamente com instantes de injeção mais tardios.

Quanto à questão de emissões, as investigações de Yilmaz et al. [94] mostraram que misturas DBE conseguem amenizar a tendência de elevação nas emissões de $\mathrm{NO}_{\mathrm{x}}$ atribuídas ao uso do biodiesel, porém às custas de um aumento nas emissões de CO e HC. Mais minuciosamente, Barabás et al. ([103] e [104]) esclarecem que a presença de etanol na mistura acarreta em maiores emissões de $\mathrm{HC}$, enquanto o biodiesel as reduz.

De acordo com a Suppes [105] de 2000, Raslavičius e Bazaras testaram um veículo abastecido com uma mistura de $70 \%$ óleo diesel com $30 \%$ biodiesel associada a $5 \%$ em volume com etanol anidro, em que foram alcançadas reduções de $40 \%$, 25\% e $6 \%$ nas respectivas emissões de material particulado, $\mathrm{HC}$ e $\mathrm{CO}$, quando comparadas ao óleo diesel. Ainda nestes testes registraramse emissões de $\mathrm{NO}_{x}$ para a mistura DBE inferiores a misturas B30 (diesel/biodiesel), porém inevitavelmente superiores às emissões de $\mathrm{NO}_{x}$ do combustível óleo diesel puro. Com relação à redução nas emissões de $\mathrm{CO}, \mathrm{He}$ et al. [106] também verificou, em 2003, esta tendência em seu trabalho e interpretou-a como sendo uma consequência da maior disponibilidade de oxigênio, o que leva a combustões mais completas, nas quais o teor das emissões de $\mathrm{CO}$ é suavizado por sua oxidação e transformação em $\mathrm{CO}_{2}$. 
Por vezes, é possível perceber certa heterogeneidade nos resultados de emissões reportados pelos autores, em função das diferentes naturezas do biodiesel utilizado em cada caso, bem como por diferenciadas concentrações dos compostos na mistura DBE e as diversas condições de testes aplicadas aos motores avaliados. $\mathrm{O}$ índice de emissões de $\mathrm{NO}_{x}$, por exemplo, que tipicamente sofre acréscimos com a introdução de biodiesel na mistura DBE, pode até mesmo ser reduzido, caso a combinação entre o etanol e o restante da mistura contribua para combustões de baixa temperatura, conforme indicam resultados apresentados por alguns autores ([30], [92], [94], [97], [102], [106], [107], [108], [109], [110], [111], [112] e [113]).

\subsection{3}

\section{Os Biocombustíveis Estabilizadores em Misturas Diesel/Etanol}

Esta dissertação propõe um enfoque de avaliação do comportamento da combustão e do desempenho do motor movido através de uma combinação entre compostos renováveis para a estabilização de misturas DBE em substituição parcial ao óleo diesel nos motores de ignição por compressão. Assim, são apresentados a seguir resultados relevantes de Guarieiro et al. [79], Lei et al. [113] e Pradelle [14] que estão a contribuir para a elaboração deste trabalho e são capazes de melhor nortear as metodologias dos testes a serem realizados em direção da maximização da participação dos biocombustíveis nas misturas ternárias DBE.

Primeiramente, em 2009, Guarieiro et al. [79] avaliaram a estabilidade de fase em misturas binárias (diesel/etanol) e misturas ternárias (DBE), utilizandose tanto etanol anidro (teor de 99,5\%) quanto etanol hidratado (teor de 95\%) a $25^{\circ} \mathrm{C}$. Os autores sinalizaram que o etanol hidratado foi insolúvel até mesmo nas misturas ternárias, ao menos para as concentrações de co-solvente investigadas. Por outro lado, o etanol anidro foi solúvel no diesel quando aplicado em uma quantidade volumétrica de $10 \%$, em que a mistura se mostrou monofásica até mesmo após 90 dias. No entanto, notou-se que o mesmo não acontecia com uma quantidade um pouco maior de etanol anidro (15\%) na mistura, quando ocorreu a separação de fase logo no primeiro dia do teste.

Então, Guarieiro et al. [79] tentaram algumas combinações entre óleo diesel, etanol anidro e co-solvente (biodiesel). Os co-solventes considerados foram: biodiesel de soja, biodiesel de mamona, biodiesel de resíduos, óleo de soja e óleo de mamona. Na maior parte das misturas das combinações de concentrações houve separação de fases após três meses de observação na 
condição de temperatura de $25^{\circ} \mathrm{C}$, com exceção de algumas misturas que se mantiveram estáveis e se tornaram objeto de estudos adicionais:

- Diesel 90\% + Etanol 10\%;

- Diesel $80 \%+$ Etanol 15\% + Biodiesel de soja 5\%;

- Diesel 80\% + Etanol 15\% + Biodiesel de mamona 5\%;

- Diesel $80 \%$ + Etanol 15\% + Biodiesel de resíduos 5\%;

- Diesel 90\% + Etanol 7\% + Óleo de soja 3\%;

- Diesel $90 \%$ + Etanol 7\% + Óleo de mamona 3\%.

Já em 2012, Lei et al. [113] estudaram a estabilidade de misturas diesel/etanol com emulsificantes simples ou compostos (de dois ou três componentes). Neste artigo de Lei et al. [113] levaram-se em conta efeitos da temperatura nas propriedades do emulsificantes, em que 16 reagentes foram selecionados como emulsificantes simples, dentre eles: óleo de mamona, óleo de chá, biodiesel de resíduos alimentares, óleo de flúor, butanol, ácido glicerídeo, acetato de etilo e outros. Inicialmente os autores perceberam que as misturas etanol/diesel com $10 \%$ volumétricos de etanol anidro em temperaturas acima de $25^{\circ} \mathrm{C}$ foram capazes de se manter estáveis para cada um dos emulsificantes simples testados. Conforme a temperatura foi reduzida, as misturas de etanol/diesel com $10 \%$ de teor volumétrico de etanol foram se tornando instáveis com cada um dos emulsificantes simples testados, em que o aditivo que se destacou foi o óleo de mamona, o qual somente apresentou separação de fase à temperatura de $10^{\circ} \mathrm{C}$. Elevando-se o teor volumétrico de etanol nas misturas etanol/diesel para $15 \%$, a separação entre fases ocorreu nas temperaturas logo abaixo dos $20^{\circ} \mathrm{C}$ para os emulsificantes simples que apresentaram melhor comportamento (óleo de mamona, óleo de chá, biodiesel de resíduos alimentares e óleo de flúor).

Nos testes com emulsificantes compostos, primeiramente avaliou-se o comportamento dos emulsificantes compostos por dois componentes em mesma proporção de volume (razão volumétrica 1:1) e observou-se que estes apresentaram melhores performances comparativamente à utilização de emulsificantes simples. Com a aplicação de emulsificantes compostos por três componentes, de razão volumétrica $1: 1: 1$, os resultados foram ainda melhores do que aqueles com o uso de emulsificantes compostos por dois componentes, o que comprova-se pela ocorrência de um emulsificante que garantiu que não houvesse a separação de fases a $10^{\circ} \mathrm{C}$ tanto para a mistura com teor volumétrico de $10 \%$ de etanol anidro quanto naquela com teor volumétrico de $15 \%$. Por ora, vale mencionar que, novamente, os emulsificantes que continham 
o óleo de mamona como um de seus componentes, apresentaram os resultados mais expressivos, seja nos compostos de duas substâncias ou no de três:

- Óleo de mamona + Biodiesel de resíduos alimentares;

- Óleo de mamona + Biodiesel de resíduos alimentares + Butanol.

Não obstante, Lei et al. [113] concluem que a estabilidade em baixas temperaturas das misturas etanol/diesel não demonstrou-se satisfatória, mesmo com o emprego de emulsificantes compostos por três componentes. Então, os autores propõem uma nova mistura de emulsificantes, por eles denominada "CLZ", a qual é formada por biocombustível, óleo de mamona e outros emulsificantes (não especificados no artigo) em proporções especiais.

Os testes realizados apontaram que pela utilização do aditivo "CLZ" foi possível manter a estabilidade de uma mistura com $10 \%$ de teor volumétrico de etanol entre a faixa de $0^{\circ} \mathrm{C}$ e $35^{\circ} \mathrm{C}$ e, além disso, com apenas $0,8 \%$ de teor volumétrico do aditivo "CLZ" pôde-se observar uma mistura clara, transparente e uniforme durante até 60 dias a $0^{\circ} \mathrm{C}$. Os autores afirmam ainda que a estabilização de misturas com $15 \%$ de teor volumétrico de etanol foi alcançada para uma ampla faixa de temperatura, bem como fora possível a obtenção de misturas consideradas monofásicas para teores volumétricos de $20 \%$ e $25 \%$ de etanol entre temperaturas de aproximadamente $20^{\circ} \mathrm{C}$ a $25^{\circ} \mathrm{C}$.

Recentemente, Pradelle [14] abordou em sua tese de doutorado alguns pontos relevantes na caracterização química de diferentes misturas DBE, assim como o desenvolvimento da combustão e o desempenho do motor na utilização das referidas misturas como combustíveis. Seus testes resumiram-se em misturas compostas por diesel, etanol anidro, biodiesel e um aditivo co-solvente. A formulação deste aditivo co-solvente é baseada em materiais de fontes renováveis (óleo de mamona, biodiesel de soja e n-butanol), permitindo ganhos significativos na estabilidade da mistura DBE entre $15^{\circ} \mathrm{C}$ e $10^{\circ} \mathrm{C}$ com a utilização de pelo menos $1 \%$ em proporção volumétrica deste co-solvente. Ademais, as misturas DBE avaliadas apresentaram teores volumétricos de etanol anidro de até $20 \%$ e proporções de biodiesel de até $15 \%$ em teor volumétrico.

Por fim, Pradelle [14] classifica a participação em crescente proporção dos biocombustíveis misturados aos combustíveis fósseis como uma estratégia promissora que, apesar de demandar ajustes nos instantes de injeção de combustível e cuidados com a bomba injetora, não exige alterações estruturais ou adequações complexas nos motores de ignição por compressão para a substituição parcial de combustíveis fósseis. 


\section{3 \\ Aparato e Procedimento Experimental}

Este terceiro capítulo traz descrições gerais sobre o motor, dinamômetro e equipamentos auxiliares envolvidos na obtenção dos dados experimentais. Neste capítulo também está abordado o procedimento experimental, isto é, a metodologia adotada para a realização dos testes. Vale ressaltar que a execução dos ensaios aconteceu no Laboratório de Engenharia Veicular da PUC-Rio, localizado na Gávea.

A Figura 16 ilustra, através de desenho esquemático, uma visão geral do arranjo experimental, considerando os equipamentos disponíveis para os testes.

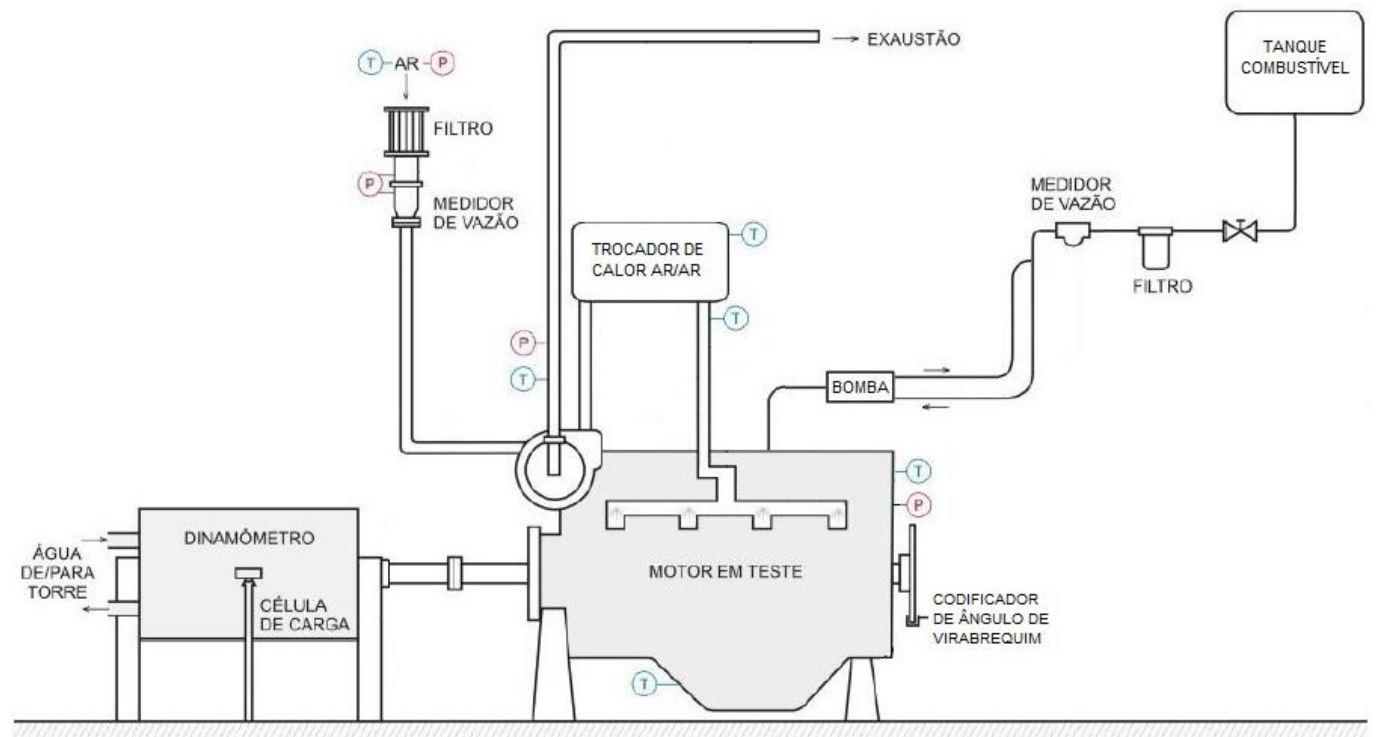

Figura 16 - Desenho esquemático do aparato experimental

\section{1}

\section{Motor MWM 4.10 TCA}

Para os testes desta dissertação utilizou-se um motor de ignição por compressão de quatro tempos, com quatro cilindros em linha, de fabricação MWM (Motoren Werke Mannheim), modelo 4.10 TCA. Ilustrado pela Figura 17 e instrumentado para medição de parâmetros diversos, o motor dispõe originalmente de $107 \mathrm{~kW}$ de potência máxima a 2600 RPM e torque máximo verificado de $430 \mathrm{Nm}$ a $1800 \mathrm{RPM}$ [31]. Este modelo da MWM é um motor de 
injeção direta, dotado de turbo-compressor, arrefecimento do ar de admissão (intercooler) e especialmente utilizado em aplicações veiculares (caminhões leves e veículos comerciais).

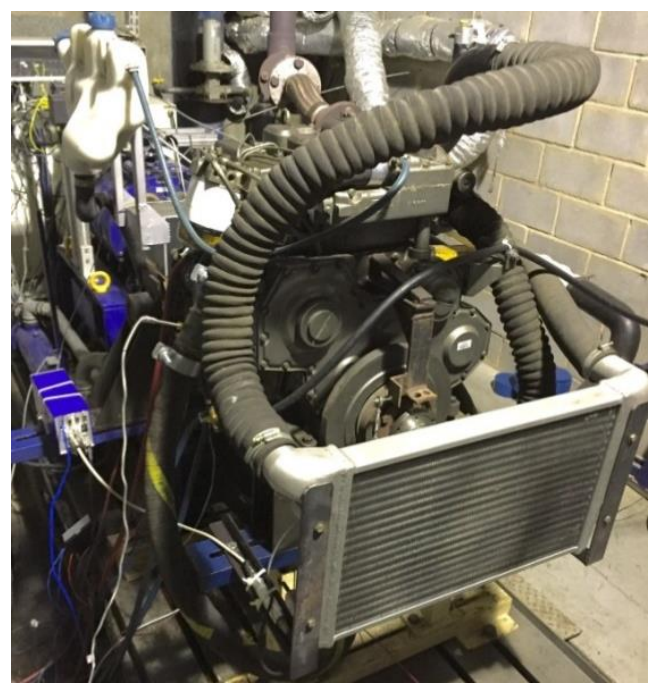

Figura 17 - Motor MWM 4.10 TCA no dinamômetro de bancada

A Tabela 2 resume dados básicos relevantes do motor MWM 4.10 TCA, segundo informações já levantadas nas teses de doutorado de Egúsquiza [31] e de Pereira [114]:

Tabela 2 - Especificações do motor MWM 4.10 TCA

\begin{tabular}{|c|c|}
\hline Diâmetro do Pistão & $103 \mathrm{~mm}$ \\
\hline Curso do Pistão & $129 \mathrm{~mm}$ \\
\hline Comprimento da Biela & $207 \mathrm{~mm}$ \\
\hline Cilindrada Total & $4300 \mathrm{~cm}^{3}$ \\
\hline Número de Cilindros/Arquitetura & 4/em linha \\
\hline Número de Válvulas por Cilindro & 2 \\
\hline Razão de compressão & $15,8: 1$ \\
\hline Início da Injeção Original do Motor & $9^{\circ} 14^{\prime} \pm 1,2^{\prime}$ (BTDC) \\
\hline Temperatura da Água de Arrefecimento & $80^{\circ} \mathrm{C}-90^{\circ} \mathrm{C}$ \\
\hline Lubrificante & SAE $15 W-40$ \\
\hline Temperatura do Lubrificante & $90^{\circ} \mathrm{C}-110^{\circ} \mathrm{C}$ \\
\hline Potência Máxima & 107 kW (@ 2600 RPM) \\
\hline Torque Máximo & 430 Nm (@1800 RPM) \\
\hline Rotação Máxima & 2600 RPM \\
\hline Turbo-Compressor e Intercooler & Sim \\
\hline
\end{tabular}

O motor testado apresenta uma bomba injetora distribuidora de especificação VE fabricada pela $\mathrm{BOSCH}$, conforme ilustrado pela Figura 18 [31]. 


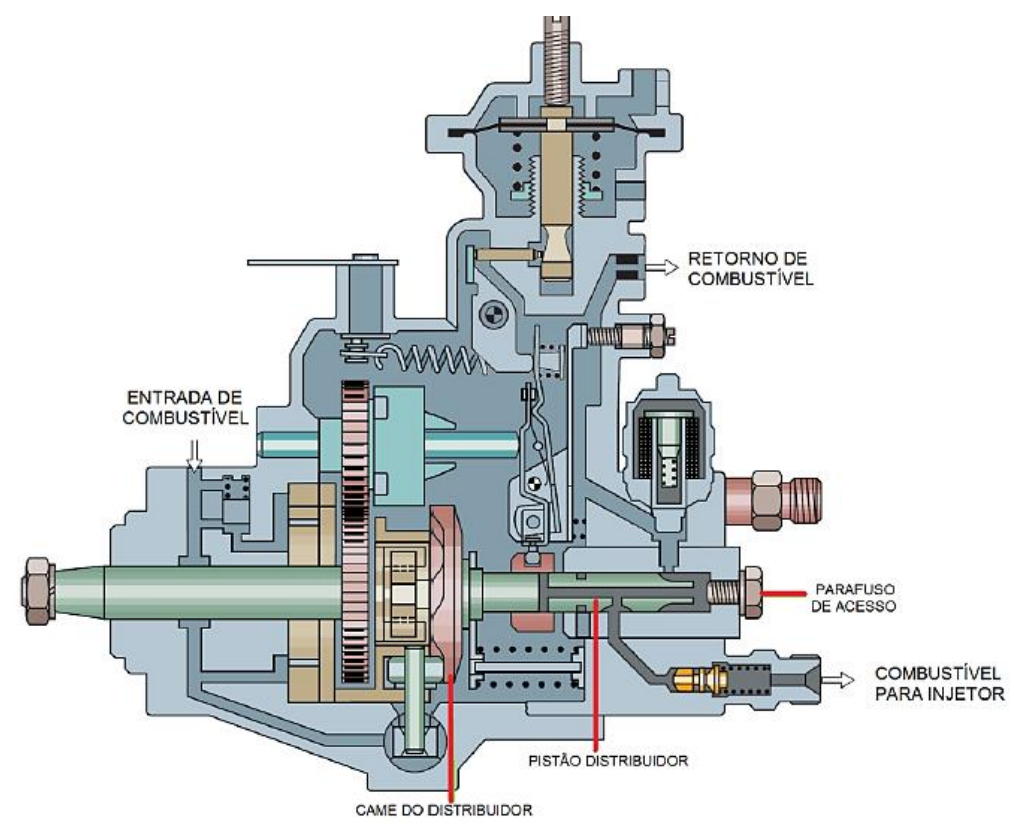

Figura 18 - Desenho da bomba injetora distribuidora BOSCH VE

Pela plaqueta original do motor e com a informação da tese de doutorado de Pereira [114] apresentada na Tabela 2, sabe-se que o início da injeção original do motor é dado por $9^{\circ} 14^{\prime}$ BTDC, o que se traduz em um deslocamento de $1,10 \mathrm{~mm}$ do pistão distribuidor da bomba. A sugestão do fabricante do motor para o ajuste do instante de injeção original, segundo o Manual de Oficina [115], é que tão logo o pistão do último cilindro do motor (lado das engrenagens) atinja - TDC, o pistão distribuidor da bomba também já tenha cumprido seu deslocamento desejado (1,10 mm no caso do motor em questão) em função de seu curso total, o qual é definido pela altura do cames distribuidor.

Para a execução de qualquer ajuste de avanço da injeção exige-se a retirada do parafuso de acesso para a instalação de um dispositivo de rosca capaz de fixar um relógio comparador, cujo apalpador toque a extremidade do pistão distribuidor no interior da bomba injetora. Então, ao girar-se manualmente o eixo do motor até que o pistão do último cilindro atinja o TDC (indicado por uma marcação original de referência no volante), o relógio comparador deve mostrar um valor equivalente a 1,10 mm. Consequentemente, a exibição de valores inferiores a $1,10 \mathrm{~mm}$ no relógio comparador sugerem injeções atrasadas em relação ao avanço original e, por outro lado, valores superiores indicam injeções mais antecipadas. Todavia, cabe ressaltar que a indicação do valor de $1,10 \mathrm{~mm}$ representa um ajuste estático do início da injeção de combustível equivalente ao avanço de $9^{\circ}$ 14' BTDC, ou seja, este ajuste é uma predefinição sem que o motor esteja em operação. 
Para ajustes de instantes de injeção diferentes do original do motor ( $9^{\circ} 14^{\prime}$ $\mathrm{BTDC}$ ), a BOSCH sugeriu alguns procedimentos a serem seguidos, conforme dividido abaixo em três etapas:

- Primeiramente, em posse da tabela que correlaciona os ângulos do came desta bomba com seu deslocamento do pistão distribuidor - disponibilizada pela BOSCH e apresentada no Anexo A - deve-se procurar qual ângulo desta tabela está associado ao valor de deslocamento do pistão distribuidor na configuração original do motor, ou seja, aproximadamente 1,10 mm;

- Em seguida, para o adiantamento da injeção, é preciso somar ao ângulo do came determinado na etapa anterior deste procedimento (ou subtrair, caso procure-se atrasar a injeção) metade da diferença entre o ângulo de injeção original e aquele que se deseja estabelecer. Vale destacar que esta proporção de 1:2 entre as diferenças dos ângulos do came da bomba e da injeção acontece em razão do funcionamento por quatro tempos do motor em questão;

- Por fim, o curso do pistão distribuidor para o novo instante de injeção estará definido pelo valor indicado para este parâmetro na tabela do Anexo $A$ que esteja associado ao ângulo do came calculado na etapa anterior.

\section{2 \\ Dinamômetro Elétrico de Bancada}

O dinamômetro empregado ao longo dos testes é de fabricação AVL, modelo Start. O equipamento conta com freio elétrico, modelo ALPHA 240, e é capaz de avaliar motores com torque máximo de até $550 \mathrm{Nm}$. Os limites máximos de potência e rotação são, respectivamente, 240 kW e 7500 RPM.

Na Figura 19 segue apresentado o dinamômetro Start da AVL, instalado no laboratório e acoplado ao motor MWM 4.10 TCA a ser testado.

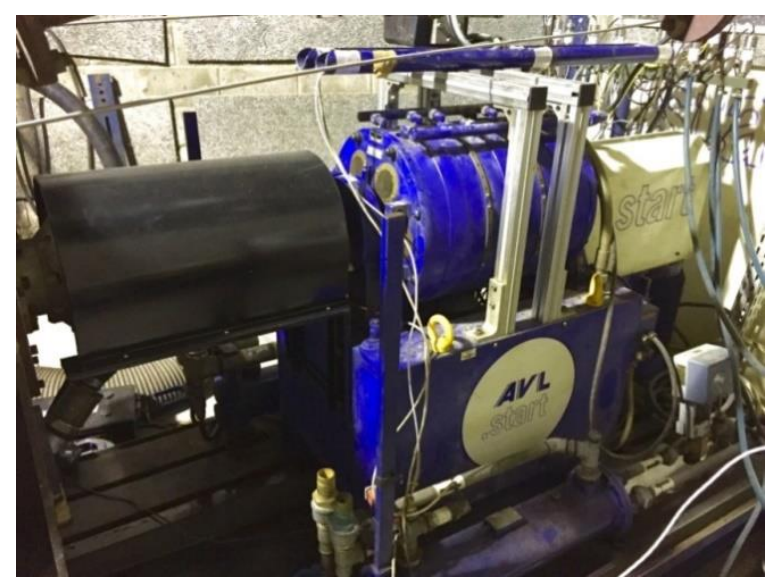

Figura 19 - Dinamômetro de bancada AVL, modelo Start 


\section{3 \\ Sistemas de Arrefecimento}

A refrigeração do conjunto motor-dinamômetro é composta por um trocador de calor água/água do tipo casco-tubo, responsável por transferir o calor da água dos sistemas de arrefecimento (do bloco do motor e do dinamômetro) para a água de uma torre de resfriamento, conforme se observa no canto inferior esquerdo da Figura 20. A partir de um controlador do dinamômetro, a vazão de água da torre para o trocador de calor é regulada, permitindo que a temperatura da água do bloco mantenha-se sempre estável, de acordo com o valor nominal especificado pelo fabricante. Vale, então, ressaltar que para este modo de controle de temperatura, retirou-se a válvula termostática do motor, de maneira que a água de arrefecimento circulasse livremente pelo trocador e os ajustes na vazão pudessem ser controlados pelo dinamômetro.

Já o arrefecimento do ar de admissão no motor é realizado por um trocador de calor ar/ar (intercooler), instalado entre o compressor do turbocompressor do motor e o coletor de admissão. No lado direito da Figura 20 é possível notar a presença deste trocador ar/ar.

Além disto, o banco de testes também dispõe de um trocador de calor água/óleo, em que não se consideram controles relacionados à temperatura do óleo lubrificante. Há apenas o monitoramento e o registro da temperatura do óleo durante todos os ensaios, respeitando-se valores representativos das temperaturas nominais.

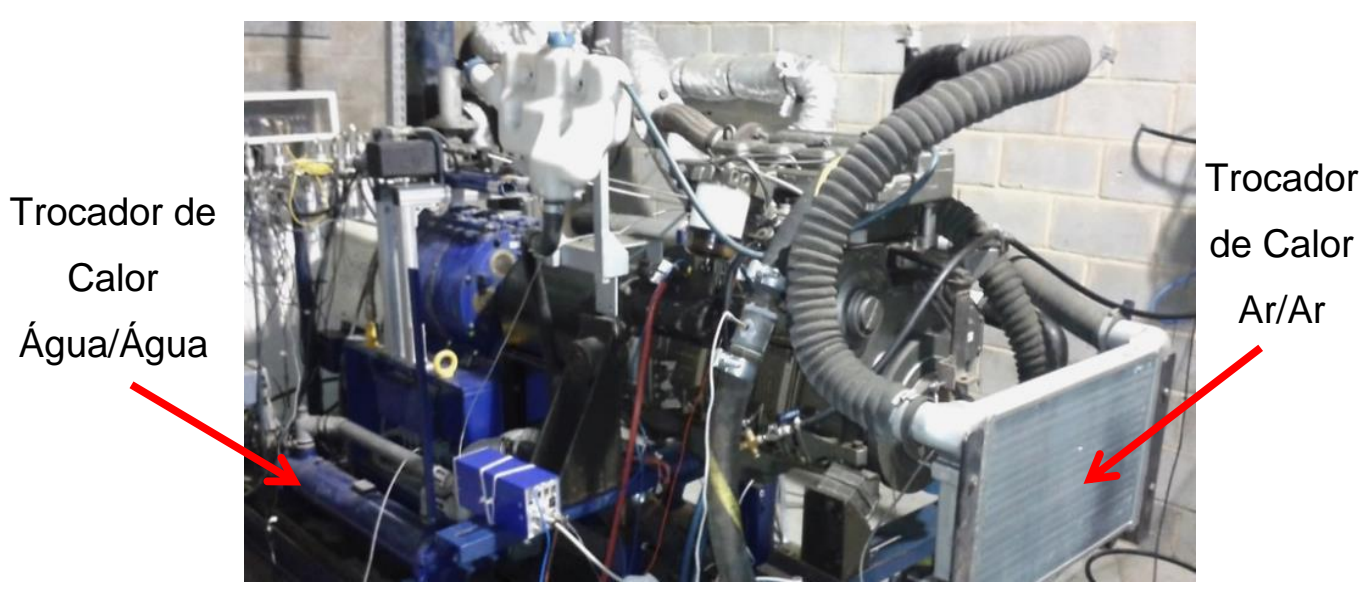

Figura 20 - Posicionamento dos trocadores de calor na bancada 


\section{4 \\ Equipamentos Complementares}

Auxiliando o funcionamento do conjunto principal motor-dinamômetro do aparato experimental deste trabalho, há outros equipamentos de função complementar, mas que também são essenciais ao desenvolvimento dos testes, tais como: medidores de vazão, transdutores e aparelhos eletrônicos.

O medidor de vazão utilizado para avaliar o consumo de ar pelo motor é do tipo laminar da marca MERIAM, modelo 50MC2-4. Este equipamento, ilustrado pela Figura 21, é internamente formado por uma matriz de tubos capilares com diâmetros muito inferiores aos seus comprimentos, induzindo o ar de admissão ao regime laminar. Assim, a vazão de fluido comporta-se de maneira aproximadamente linear com a diferença de pressão medida entre a entrada e a saída do instrumento. Para o funcionamento adequado do medidor de vazão laminar, é recomendada a instalação de tubos retos a montante e a jusante do equipamento com comprimentos que representem, respectivamente, 10 e 5 vezes dos diâmetros de entrada e saída.

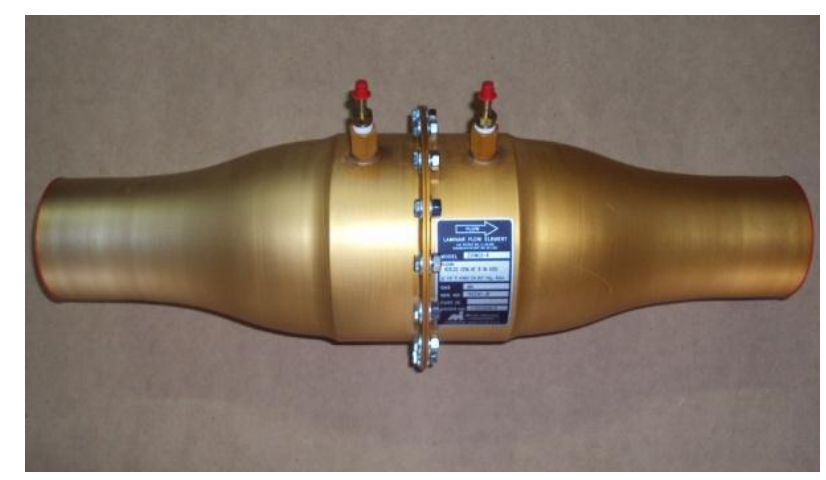

Figura 21 - Medidor de vazão laminar do consumo de ar

Para a medição de consumo instantâneo de combustível considera-se um medidor de vazão do tipo Coriolis da marca MICRO MOTION, modelo CMF010, conforme mostra a Figura 22. Este aparelho é formado, essencialmente, por dois componentes: sensor (composto por um ou dois tubos vibrantes em formato de U) e transmissor eletrônico. Então, quando o combustível passa pelo tubo ocorre o efeito Coriolis, o que gera uma inclinação no tubo durante sua vibração. A inclinação é medida através de detectores de posição, os quais enviam sinais elétricos não padronizados para o transmissor. Em seguida um sinal elétrico padrão proporcional à vazão instantânea que circula pelo tubo é emitido pelo transmissor. Neste medidor de vazão de combustível não há exigências 
relacionadas ao uso de trechos retos a sua montante ou jusante, portanto a linha de fornecimento das misturas de combustíveis utiliza mangueiras flexíveis.

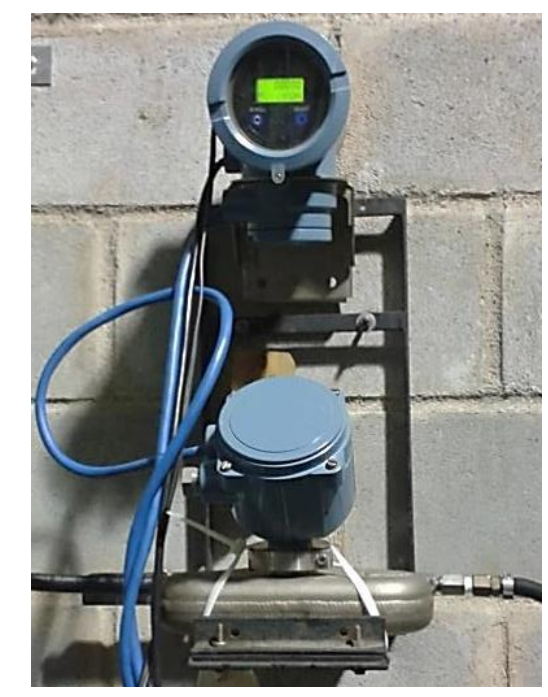

Figura 22 - Medidor de vazão Coriolis do consumo de combustível

Posicionado no cabeçote do quarto cilindro do motor (lado oposto ao volante do motor), há um transdutor de pressão piezoeléctrico de fabricação KISTLER, modelo 6052CS31U20, capaz de medir pressões dinâmicas de até 300 bar. Associado a este transdutor, existe também um amplificador da marca AVL, modelo FlexiFEM, que converte o sinal da carga elétrica de saída do transdutor de pressão piezoeléctrico em um sinal de tensão amplificado. Por fim, o sinal amplificado é coletado pelo INDIMETER 619 e processado pelo software INDICOM, ambos do fabricante AVL.

A determinação das posições angulares ocorre através do codificador de ângulo de virabrequim da marca KISTLER, modelo 2614A1, com resolução de um décimo de grau de ângulo de virabrequim. Este equipamento também é conectado ao INDIMETER 619, o que permite a multiplicação do número de pulsos para que se tenha uma resolução de um grau do eixo de virabrequim e também viabilize-se a associação entre as pressões coletadas no interior do cilindro e suas respectivas posições de ângulo de virabrequim.

Para cada teste executado, o sistema de aquisição é programado para registrar 300 ciclos do motor e calcular o valor médio representativo da pressão em cada grau de ângulo de virabrequim. A Figura 23 é um desenho esquemático que resume as medições e demais etapas, até a apresentação dos valores de pressão no interior do cilindro em função dos ângulos de virabrequim. 


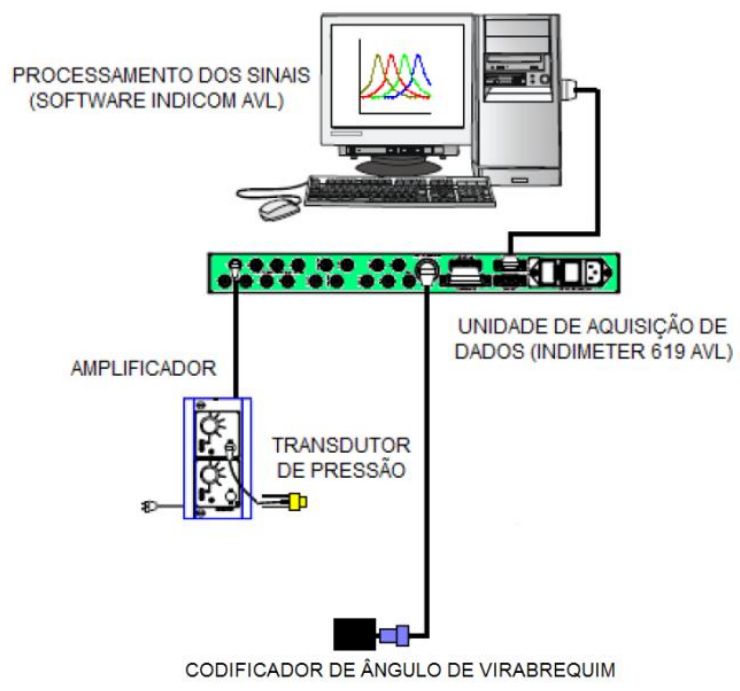

Figura 23 - llustração da medição de pressão durante os testes

Ainda, é importante mencionar que para as análises termodinâmicas averiguadas nesta dissertação, os valores de pressão devem ser considerados em pressão absoluta. Assim, levando-se em conta a instalação de um transdutor piezoresistivo no coletor de admissão, o procedimento adotado estimou a pressão no cilindro na posição do BDC como equivalente ao valor médio da pressão absoluta no coletor.

Esta estimativa é bem razoável, visto que no referido momento do ciclo o pistão encontra-se praticamente parado, enquanto a válvula de exaustão está fechada e a válvula de admissão aberta. Consequentemente, isto indica que, para instantes iniciais do ciclo do motor, a estimativa da pressão absoluta no interior do cilindro pela pressão média no coletor de admissão mostra-se suficientemente precisa.

De qualquer forma, o fator de ajuste da pressão é calculado com um intervalo de medição de $5^{\circ} \mathrm{CA}$ (iniciando-se no $\mathrm{BDC}$ ) a fim de que se reduzam os possíveis efeitos de ruído na medição. Após definir-se o fator de ajuste da pressão no intervalo do ciclo entre $\mathrm{O} B D C$ e $5^{\circ}$, este valor pode também ser aplicado de maneira mais abrangente nas estimativas de pressões absolutas para cada grau de ângulo de virabrequim do ciclo representativo, quando em posse das respectivas pressões dinâmicas referentes ao teste em questão.

Finalmente, esclarece-se que três transdutores de pressão piezoresistivos, de fabricação SENSOTEC (série FP 2000), estiveram instalados em diferentes pontos do motor e foram responsáveis por medir as pressões diferenciais necessárias ao cálculo da vazão de ar úmido e as pressões estacionárias do ar de admissão e de exaustão. Termopares do tipo $\mathrm{K}$ foram utilizados para os 
registros da temperatura na admissão (temperatura da sala de testes) e na exaustão. $O$ transdutor de umidade relativa atmosférica da sala de testes é da marca OMEGA. A temperatura do fluido do sistema de arrefecimento do motor também se manteve monitorada.

\section{5}

\section{Procedimento Experimental}

Antes do início de qualquer avaliação no motor, é necessário que este esteja devidamente aquecido, ou seja, com as temperaturas da água de arrefecimento e do óleo lubrificante em torno de seus valores nominais (respectivamente em torno de $85^{\circ} \mathrm{C}$ e $90^{\circ} \mathrm{C}$ nas condições de diesel comercial B7). Além disto, para uma série de medidas típicas, o dinamômetro, o filtro e as linhas de combustível têm seu funcionamento ajustado no ponto de operação referente à condição e ao combustível que se deseja analisar. Aguarda-se também a mudança integral do combustível na linha, se este for o caso, e a estabilização dos parâmetros para que, então, sejam efetuados os registros.

É importante mencionar que durante a execução dos testes levam-se em conta cuidados para a minimização de incertezas associadas como, por exemplo, a reprodução de pelo menos três ensaios para cada condição experimental proposta. A curva de pressão indicada coletada em cada um dos ensaios configura-se como uma média de 300 ciclos rodados no motor com covariância menor do que 10\%, conforme sugere Heywood [1].

A metodologia adotada para o trabalho é estabelecida segundo quatro combinações básicas de parâmetros:

$>$ Combustível;

$>$ Torque;

$>$ Rotação;

$>$ Instante de injeção do combustível.

Ao total, seis combustíveis são inicialmente avaliados. O diesel comercial (B7) é testado para o estabelecimento de condições de referência (baseline condition) pelas quais as análises com os demais combustíveis possam se fundamentar. Além disto, o diesel comercial B7 faz parte da formulação original de todas as misturas elaboradas para os testes, isto é, os demais combustíveis (B15E0, B15E5, B15E10, B15E15 e B15E20) são compostos por misturas entre diesel B7, biodiesel puro e o aditivo estabilizador de misturas do trabalho de Pradelle [14], bem como etanol anidro nos casos em que este álcool é aplicável.

O teor volumétrico utilizado para etanol anidro é de até $20 \%$ nas misturas, 
fundamentado nas investigações sobre as propriedades deste álcool em misturas ternárias (diesel/biodiesel/etanol) realizadas por Pradelle [14]. Já a concentração volumétrica de biodiesel nas misturas ternárias de até $15 \%$ é selecionada de maneira a estabelecer um valor médio entre o máximo teor de biodiesel (20\%) misturado ao óleo diesel autorizado pela Resolução $n^{\circ} 3$ do Conselho Nacional de Política Energética, de 21 de setembro de 2015 e o percentual volumétrico de adição obrigatória de biodiesel (10\%) misturado ao óleo diesel, a entrar em vigor 36 meses após a promulgação da Lei n 13.263 , de 23 março de 2016.

Vale lembrar que algumas propriedades físico-químicas relevantes dos combustíveis encontram-se listadas no Apêndice A. No Anexo B apresenta-se a caracterização da mostra de diesel B7 e no Anexo C a caracterização da amostra de biodiesel puro.

O aditivo co-solvente desenvolvido por Pradelle, apresentado em sua tese de doutorado [14], possui formulação protegida pelo pedido de patente registrado em 9 de Março de 2017 com a Peugeot Citroën do Brasil Automóveis Ltda. no Institut National de la Propriété Industrielle [116]. O documento reúne informações relativas à influência do aditivo na estabilidade das misturas e sua formulação fundamental, a saber: $72,5 \%$ de óleo de mamona, 17,5\% de biodiesel de soja e 10\% de n-butanol (em teores volumétricos).

A seguir, a Tabela 3 encarrega-se de listar os combustíveis utilizados neste trabalho e suas respectivas composições, dadas em teor volumétrico:

Tabela 3 - Composições dos combustíveis em teor volumétrico

\begin{tabular}{c|cccc}
\hline Combustível & \% Diesel & \% Biodiesel & \% Etanol Anidro & Aditivo \\
\hline B7(Diesel Comercial) & $93,0 \%$ & $7,0 \%$ & $0,0 \%$ & Não \\
B15E0 & $85,0 \%$ & $15,0 \%$ & $0,0 \%$ & $\mathrm{Sim}^{*}$ \\
B15E5 & $80,7 \%$ & $14,3 \%$ & $5,0 \%$ & $\mathrm{Sim}^{*}$ \\
B15E10 & $76,5 \%$ & $13,5 \%$ & $10,0 \%$ & $\mathrm{Sim}^{*}$ \\
B15E15 & $72,2 \%$ & $12,8 \%$ & $15,0 \%$ & $\mathrm{Sim}^{*}$ \\
B15E20 & $68,0 \%$ & $12,0 \%$ & $20,0 \%$ & $\mathrm{Sim}^{*}$
\end{tabular}

* $\mathrm{O}$ aditivo é aplicado em quantidade equivalente a $1 \%$ do volume total de cada mistura, garantindo a miscibilidade e homogeneidade destes combustíveis.

As combinações de pares de torque versus rotação definem-se por percentuais dos torques máximos alcançados nos testes com combustível B7 em três diferentes rotações do motor: 1500, 1800 e 2100 RPM. Nas condições atuais do motor, a condição de máxima potência aos 2600 RPM não é mais 
atingida, todavia há boa faixa de torque à disposição nas três rotações selecionadas para os testes.

Adicionalmente, em virtude da característica do etanol em postergar o início da combustão, que pode causar em alguns casos prejuízos ao desempenho do processo de combustão, já se espera que os demais combustíveis não alcancem as mesmas condições de torques máximos do diesel B7. Por isso, para os demais combustíveis, substitui-se especificamente a condição de torque máximo do combustível B7 pelo valor mais elevado atingido para este parâmetro com cada combustível. Assim, estas condições de torques máximos não são comparáveis entre si, pois são singulares. Todavia, apresentam-se como condições importantes na representação da performance máxima do motor com cada mistura para as rotações selecionadas.

A Tabela 4 descreve e esclarece as combinações entre torque e rotação designadas para cada combustível e avanço estudado ao longo dos testes:

Tabela 4 - Pares de torque versus rotação

\begin{tabular}{|c|c|}
\hline Rotação (RPM) & Torque \\
\hline \multirow{3}{*}{1500} & $25 \%$ do torque máximo de $\mathrm{B} 7$ \\
\hline & $50 \%$ do torque máximo de $\mathrm{B} 7$ \\
\hline & $100 \%$ de torque do combustível em teste \\
\hline \multirow{3}{*}{1800} & $25 \%$ do torque máximo de $\mathrm{B} 7$ \\
\hline & $50 \%$ do torque máximo de $\mathrm{B} 7$ \\
\hline & $100 \%$ de torque do combustível em teste \\
\hline \multirow{3}{*}{2100} & $25 \%$ do torque máximo de $B 7$ \\
\hline & $50 \%$ do torque máximo de $\mathrm{B} 7$ \\
\hline & $100 \%$ de torque do combustível em teste \\
\hline
\end{tabular}

A injeção de combustível para os testes das condições de referência com o combustível B7 é fixado em um avanço estático de aproximadamente 10,5 BTDC, que representa $1,25 \mathrm{~mm}$ de deslocamento do pistão distribuidor da bomba. Este valor é uma modificação do instante de injeção original do motor (equivalente a $9^{\circ}$ 14' BTDC) que representa um leve adiantamento da injeção de combustível já realizado na tese de Egúsquiza [31]. Na tese de Pradelle [14] esta modificação no instante de injeção (10,5 BTDC) também é utilizada, aliando um bom desempenho do motor a condições mais favoráveis à autoignição de misturas com etanol. A alteração no instante de injeção evita que os resultados dos testes de referência com o combustível B7 se distanciem excessivamente dos demais testes sujeitos à presença de etanol, o que poderia, eventualmente, comprometer a execução da metodologia proposta para os pares de torque 
versus rotação, por exemplo.

A metodologia aqui apresentada, no âmbito dos instantes de injeção de combustível, consiste em inicialmente avaliar cada combinação estabelecida de rotação, torque e combustível, com o referido avanço de 10,5 BTDC. Em seguida, a continuidade do estudo está associada à verificação de instantes de injeção otimizados das misturas com etanol, potencializando o desempenho do motor e minimizando efeitos negativos da presença deste álcool nas misturas. Em função da quantidade de combustível disponibilizada para os testes, priorizase o estudo de misturas com etanol e, por isso, não são consideradas buscas por instantes ótimos de injeção das misturas sem etanol (B15E0 e B7).

Além do instante de injeção inicial empregado nos testes para todos os combustíveis (10,5 $5^{\circ}$ BTDC), são estudados outros três avanços para cada mistura com etanol, totalizando-se quatro condições experimentais de avanços suficientes para que se tracem tendências consistentes do desempenho do motor com a variação dos instantes de injeção. A escolha destes demais avanços é norteada pela expectativa de que misturas com maiores teores de etanol apresentem avanços otimizados mais antecipados em virtude dos maiores atrasos na ignição [60] e, principalmente, pela análise dos resultados exibidos por cada tentativa de avanço da injeção.

A realização dos testes para a pesquisa de otimização dos instantes de injeção de misturas com etanol permite a elaboração da Tabela 5.

Tabela 5 - Ângulos investigados nos processos de otimização

\begin{tabular}{|c|c|}
\hline Mistura & Ângulo de Injeção (BTDC) \\
\hline & $8,5^{\circ}$ \\
\hline & $9,5^{\circ}$ \\
\hline & $10,5^{\circ}$ \\
\hline & $11,5^{\circ}$ \\
\hline & $9,5^{\circ}$ \\
\hline & $10,5^{\circ}$ \\
\hline & $11,5^{\circ}$ \\
\hline & $12,5^{\circ}$ \\
\hline & $9,5^{\circ}$ \\
\hline & $10,5^{\circ}$ \\
\hline & $11,5^{\circ}$ \\
\hline & $12,5^{\circ}$ \\
\hline & $10,5^{\circ}$ \\
\hline & $11,5^{\circ}$ \\
\hline
\end{tabular}


Portanto, esta etapa da metodologia avalia as misturas com etanol (B15E5, B15E10, B15E15 e B15E20) nas condições de torque e rotação da Tabela 4 em busca de instantes ótimos para a injeção de combustível. A determinação do avanço ótimo para cada mistura baseia-se na investigação empírica, isto é, observa-se pela tentativa com diferentes instantes de injeção aquele no qual ocorre a minimização do consumo específico de combustível com a utilização das misturas no motor.

Por fim os ajustes mecânicos necessários ao estabelecimento dos avanços estáticos, os quais se traduzem pela aplicação de valores para deslocamentos do pistão distribuidor da bomba injetora, estão listados na Tabela 6. Cabe ressaltar que os deslocamentos de pistão distribuidor da bomba relacionam-se diretamente com os ângulos de virabrequim da injeção de combustível e ângulos do came da bomba, respeitando os procedimentos indicados pelo fabricante (BOSCH) da bomba descritos no item 3.1.

Tabela 6 - Ângulos de injeção e ajustes na bomba

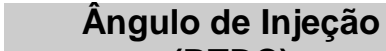

(BTDC)

$8,5^{\circ}$

$9^{\circ} 14^{\prime}$ (original do motor)

$9,5^{\circ}$

$10,5^{\circ}$

$11,5^{\circ}$

$12,5^{\circ}$

$13,5^{\circ}$

\section{Ângulo do Came}

$6^{\circ} 37^{\prime} 50$ "

$6^{\circ} 52^{\prime} 50^{\prime \prime}$

$7^{\circ} 7^{\prime} 50^{\prime \prime}$

$7^{\circ} 37^{\prime} 50^{\prime \prime}$

$8^{\circ} 7^{\prime} 50$ "

$8^{\circ} 37^{\prime} 50^{\prime \prime}$

$9^{\circ} 7$ ' 50 "
Deslocamento do Pistão Distribuidor

$1,04 \mathrm{~mm}$

$1,10 \mathrm{~mm}$

$1,15 \mathrm{~mm}$

$1,25 \mathrm{~mm}$

$1,34 \mathrm{~mm}$

$1,44 \mathrm{~mm}$

$1,53 \mathrm{~mm}$ 


\section{4 \\ Fundamentação Teórica e Redução de Dados}

A proposta deste quarto capítulo é fornecer ferramentas analíticas capazes de relacionar os dados coletados nos testes com parâmetros relevantes ao estudo do processo de combustão e do desempenho do motor, assim como também condicionar a correta elucidação dos resultados apresentados. Complementarmente às reduções de dados a serem exibidas, o Apêndice $B$ traz algumas equações auxiliares às formulações deste capítulo, ao passo que o Apêndice $\mathrm{C}$ mostra incertezas associadas às grandezas avaliadas no trabalho.

\subsection{Parâmetros Geométricos}

Antes da execução de qualquer teste no motor, suas variáveis geométricas devem ser medidas ou determinadas. Estes valores são fundamentais para que sejam estimados, por exemplo, dados de volume instantâneo através de relações geométricas entre dimensões do conjunto do motor, vide Figura 24 [1].

A expressão geométrica que estabelece a distância entre o eixo de virabrequim e o pino do pistão é indicada pela eq. (1):

$$
s=a \cos \theta+\left(l^{2}+a^{2} \operatorname{sen}^{2} \theta\right)^{\frac{1}{2}}
$$

Em que:

$s \quad$ : distância entre o eixo de virabrequim e o pino do pistão $(\mathrm{m})$;

$L \quad$ : curso do pistão $(\mathrm{m})$;

a : raio do virabrequim $(\mathrm{a}=\mathrm{L} / 2)(\mathrm{m})$;

$l \quad$ : comprimento da biela $(\mathrm{m})$;

$\theta \quad$ : ângulo de virabrequim $\left(^{\circ}\right)$.

Portanto, o volume instantâneo do cilindro em função do ângulo de virabrequim é obtido pela expressão da eq. (2):

$$
V(\theta)=V_{c}+\frac{\pi B^{2}}{4}(l+a-s)
$$

Em que:

$V(\theta) \quad$ : volume em função do ângulo de virabrequim $\left(\mathrm{m}^{3}\right)$; 

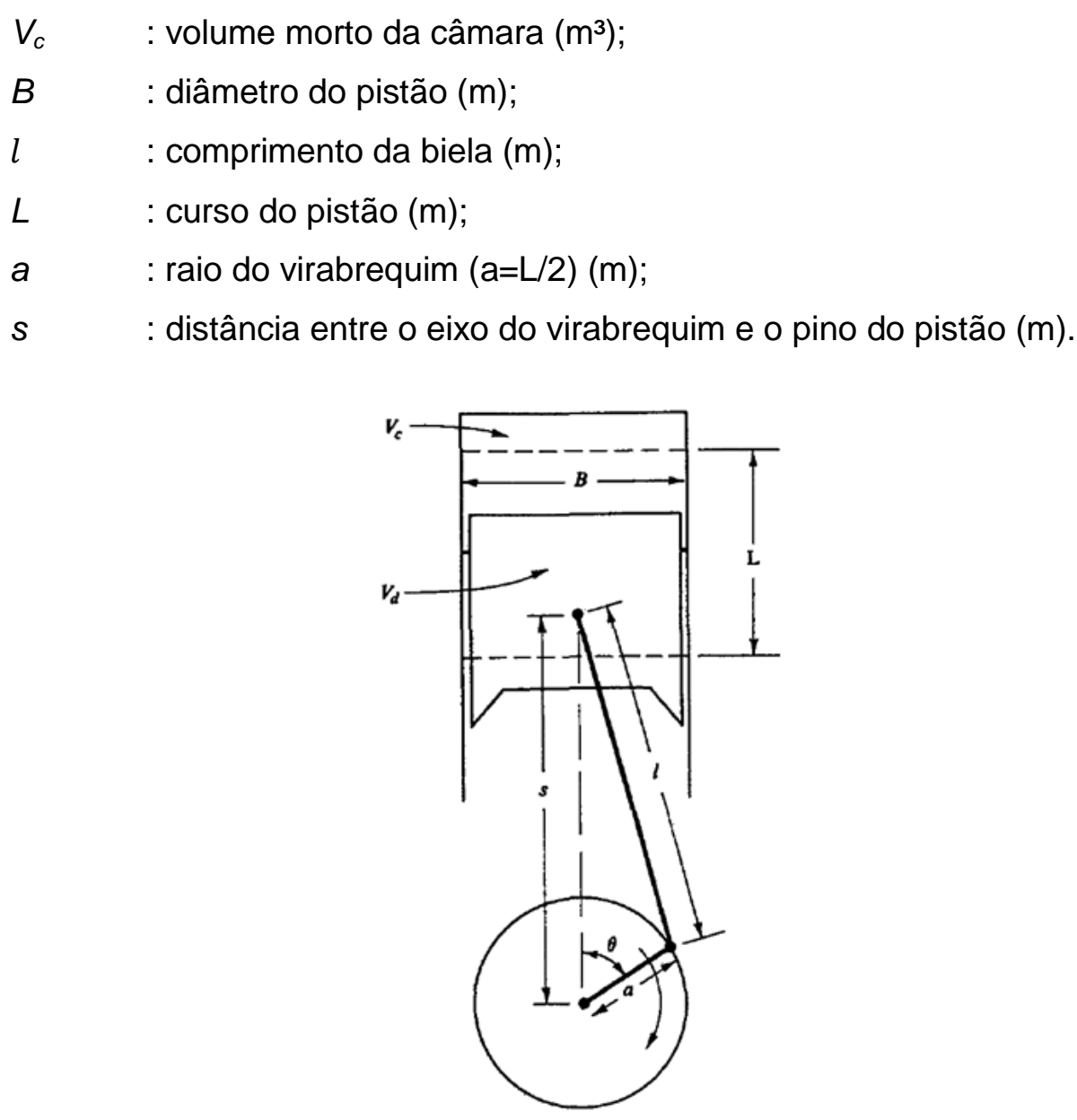

Figura 24 - Dimensões geométricas do conjunto cilindro-pistão

\section{2}

\section{Pressão Média Efetiva e Pressão Média Indicada}

A pressão média efetiva (BMEP) é um parâmetro relevante em comparações preliminares entre motores, independentemente de seu tamanho ou rotação. Quando o motor é posicionado no dinamômetro, torque e potência gerados no virabrequim permitem calcular a pressão média efetiva. No motor de quatro tempos a pressão média efetiva (BMEP) é descrita pela eq. (3) [1]:

$$
B M E P=2 \frac{P_{b}}{V_{d} N}=\frac{4 \pi}{1000} \frac{T q}{V_{d}}
$$

Em que:

$B M E P$ : pressão média efetiva $(\mathrm{kPa})$;

$P_{b} \quad$ : potência efetiva $(\mathrm{kW})$;

$V_{d} \quad$ : volume deslocado $\left(\mathrm{m}^{3}\right)$;

$N \quad$ : velocidade angular (RPM);

$\mathrm{Tq}$ : torque (Nm). 
Apesar de assemelharem-se em uma primeira análise, a pressão média efetiva (BMEP) e a pressão média indicada (IMEP) apresentam diferenças conceituais. A pressão média indicada (IMEP) é definida como a pressão hipotética constante que seria necessária no interior do cilindro para a geração de uma potência equivalente à desenvolvida devido à pressão da carga em combustão na câmara sobre os pistões. No motor de quatro tempos e quatro cilindros, a pressão média indicada calcula-se pela eq. (4), segundo a relação entre a soma de trapézios sob a curva do diagrama de Clapeyron (ou seja, o trabalho) e volume deslocado pelos cilindros:

$$
I M E P=\frac{1}{V_{d}} \sum_{i=1}^{k-1}\left(\frac{p_{i+1}+p_{i}}{2}\right)\left(V_{i+1}-V_{i}\right)
$$

Em que:

IMEP : pressão média indicada $(\mathrm{kPa})$

$V_{d} \quad$ : volume deslocado $\left(\mathrm{m}^{3}\right)$;

$k \quad$ : número de intervalos do somatório (-);

i $\quad$ : índice indicativo do instante avaliado (-);

p : pressão $(\mathrm{kPa})$;

$V \quad$ : volume $\left(\mathrm{m}^{3}\right)$.

\section{3}

\section{Potência Efetiva}

A potência efetiva $\left(P_{b}\right)$ figura como um tradicional parâmetro utilizado na avaliação do desempenho de um motor de combustão interna. Baseada essencialmente no produto entre o torque e a velocidade angular, a potência efetiva está relacionada à potência absorvida pelo dinamômetro associado ao processo de medição. Então, a expressão para a potência efetiva é dada pela eq. (5) abaixo [1]:

$$
P_{b}=\frac{2 \pi N T q}{60000}
$$

Em que:

$P_{b} \quad$ : potência efetiva $(\mathrm{kW})$;

Tq : torque $(\mathrm{Nm})$;

$N \quad$ : velocidade angular (RPM). 


\section{4 \\ Consumos Específicos e Consumo de Ar}

O consumo específico de combustível permite uma boa percepção a cerca de como o combustível está sendo aproveitado no motor para a geração de potência (ou produção de trabalho útil). Portanto, o cálculo do consumo específico de combustível pode ser obtido pela razão entre o consumo de combustível e potência de efetiva, de acordo com a eq. (6):

$$
\operatorname{cec}=\frac{\dot{m}_{c}}{P_{b}}
$$

Em que:

cec : consumo específico de combustível (kg/kWh);

$\dot{m}_{c} \quad$ : vazão mássica de combustível $(\mathrm{kg} / \mathrm{h})$;

$P_{b} \quad$ : potência efetiva $(\mathrm{kW})$.

Ainda no que se refere ao consumo específico, é possível estabelecer o consumo específico energético, o qual considera as contribuições dos valores de poder calorífico e é capaz de, inclusive, explicitar a conversão de energia individual de um combustível presente em uma mistura como, por exemplo, o etanol em uma mistura DBE.

No presente trabalho uma expressão é desenvolvida, através de manipulações algébricas, para o caso particular da avaliação do consumo específico energético de etanol em misturas DBE. Para a estimativa deste parâmetro, relacionam-se consumo específico de combustível da mistura ternária, fração mássica do álcool na mistura e consumo específico desta mistura sem etanol - que nos testes desta dissertação se traduz em consumo específico da mistura B15E0 - sob mesmas condições de torque e rotação. Por último, multiplica-se o poder calorífico inferior do etanol ao termo que acaba de ser calculado, a fim de que o consumo específico do etanol contido na mistura ternária esteja em base energética ( $\mathrm{MJ} / \mathrm{kWh})$, conforme indica a eq. (7):

$$
E c e e=\frac{100 c e c-\left(100-\%_{e, m}\right) \operatorname{cec}_{B 15 E 0}}{\%_{e, m}} P C i_{E}
$$

Em que:

Ecee : consumo específico energético de etanol em mistura (MJ/kWh);

cec : consumo específico da mistura com etanol (kg/kWh);

$\operatorname{cec}_{B 15 E O}$ : consumo específico da mistura B15E0 (sem etanol) $(\mathrm{kg} / \mathrm{kWh})$;

$\%_{e, m} \quad$ : teor de etanol na mistura (em massa) (\%); 
$P C i_{E} \quad$ : poder calorífico inferior do etanol $(\mathrm{MJ} / \mathrm{kg})$.

Já o consumo de ar refere-se ao processo de admissão no motor de combustão interna. O parâmetro de vazão mássica de ar úmido consumido pelo motor é dado pela eq. (8), relacionando-se vazão volumétrica de ar úmido e massa específica de ar úmido:

$$
\dot{m}_{a r, u}=\dot{V}_{a r, u} \rho_{a r, u}
$$

Em que:

$\dot{m}_{a r, u} \quad$ : vazão mássica de ar úmido $(\mathrm{kg} / \mathrm{h})$;

$\dot{V}_{a r, u} \quad$ : vazão volumétrica de ar úmido $\left(\mathrm{m}^{3} / \mathrm{h}\right)$;

$\rho_{a r, u} \quad$ : massa específica de ar úmido $\left(\mathrm{kg} / \mathrm{m}^{3}\right)$ (Apêndice B - eq. (B.10)).

Por sua vez a vazão mássica de ar úmido, considerando-se as condições atmosféricas de referência $\left(25^{\circ} \mathrm{C}\right.$ e $\left.101,325 \mathrm{kPa}\right)$, indicadas pelo índice "r", pode ser expressa pela eq. (9) [31]:

$$
\dot{V}_{a r, u}=\dot{V}_{r}\left(\frac{\mu_{r}}{\mu_{a r, u}}\right)\left(\frac{T_{r}}{T_{a r, u}}\right)\left(\frac{p_{a r, u}}{p_{r}}\right)\left(\frac{\rho_{a r, u}}{\rho_{r}}\right)
$$

Em que:

$\dot{V}_{a r, u} \quad$ : vazão volumétrica de ar úmido $\left(\mathrm{m}^{3} / \mathrm{h}\right)$;

$\mu_{a r, u} \quad$ : viscosidade dinâmica do ar úmido (Pa.s);

$T_{a r, u} \quad$ : temperatura do ar úmido (K);

$p_{a r, u} \quad$ : pressão do ar úmido $(\mathrm{kPa})$;

$\rho_{a r, u} \quad$ : massa específica do ar úmido $\left(\mathrm{kg} / \mathrm{m}^{3}\right)$.

A vazão volumétrica do ar úmido, nas condições atmosféricas de referência, é estimada pelo diferencial de pressão coletado por um medidor de vazão de tipo laminar, segundo a curva de calibração da eq. (10) [31]:

$$
\dot{V}_{r}=\left(54,1608 \Delta p-0,140621 \Delta p^{2}\right)
$$

Em que:

$\dot{V}_{r} \quad$ : vazão volumétrica nas condições de referência ( $\left.\mathrm{ft}^{3} / \mathrm{min}\right)$;

$\Delta p \quad$ : diferença de pressão (polegada de coluna de $\mathrm{H}_{2} \mathrm{O}$ ).

Vale ressaltar que para utilização dos valores de vazão mássica da eq. (10) na eq. (9), é necessária a conversão das unidades, já que a curva de calibração fornece o resultado em ft³/min. 
Contudo, a curva de calibração da eq. (10) é estimada considerando-se o uso de ar seco nas condições de referência. Portanto, as razões de viscosidade, temperatura, pressão e massa específica da eq. (9) são fatores de correção necessários ao cálculo da vazão volumétrica do ar úmido, os quais estão abordados mais minuciosamente no Apêndice $B$. $O$ ar úmido representa $O$ ar efetivamente admitido pelo motor, o qual é composto por ar seco e vapor d'água.

Após a determinação da vazão mássica de ar úmido e em posse dos dados de umidade absoluta, a vazão mássica de ar seco também pode ser conhecida pela relação da eq. (11):

$$
\dot{m}_{a r, s}=\frac{\dot{m}_{a r, u}}{(1+\omega)}
$$

Em que:

$\dot{m}_{a r, s} \quad$ : vazão mássica de ar seco $(\mathrm{kg} / \mathrm{h})$;

$\dot{m}_{a r, u} \quad$ : vazão mássica de ar úmido $(\mathrm{kg} / \mathrm{h})$;

$\omega \quad$ : umidade absoluta (-).

\section{5 \\ Razão Ar/Combustível e Razão de Equivalência}

A razão ar/combustível é um parâmetro que, assim como o próprio termo já sugere, indica a proporção entre ar admitido e combustível injetado no interior dos cilindros. Esta razão pode ser calculada através da vazão mássica de ar e vazão mássica de combustível, de acordo com a eq. (12) [1]:

$$
R_{A / C}=\frac{\dot{m}_{a r, s}}{\dot{m}_{c}}
$$

Em que:

$R_{A / C} \quad$ : razão ar/combustível (-);

$\dot{m}_{a r, s} \quad$ : vazão mássica de ar seco $(\mathrm{kg} / \mathrm{h})$.

$\dot{m}_{c} \quad$ : vazão mássica de combustível $(\mathrm{kg} / \mathrm{h})$.

Complementarmente à razão ar/combustível, a razão de equivalência relaciona a razão ar/combustível estequiométrica com a razão ar/combustível real utilizada em dado momento pelo motor, conforme mostra a eq. (13):

$$
\phi=\frac{\left(R_{A / C}\right)_{\text {Esteq }}}{\left(R_{A / C}\right)_{\text {Real }}}
$$


Em que:

$\phi \quad$ : razão de equivalência (-);

$\left(R_{A / C}\right)_{\text {Esteq: }}$ razão ar/combustível estequiométrica (-);

$\left(R_{A / C}\right)_{\text {Real }}$ : razão ar/combustível real (-).

Algumas estimativas das razões ar/combustível estequiométricas (em termos mássicos) são apresentadas na tese de Pradelle [14]: 14,6 para diesel, 12,3 para biodiesel e 9,0 para etanol.

A razão de equivalência é um parâmetro que essencialmente indica se a carga formada por ar e combustível no interior do cilindro é proporcionalmente rica ou pobre em termos estequiométricos, isto é, se há uma quantidade maior ou menor de combustível em função do ar admitido pelo motor, de acordo com a estequiometria estabelecida entre ar e combustível.

Portanto, quando a razão de equivalência é menor do que um a mistura ar/combustível é pobre em combustível, ou seja, há excesso de ar. Por outro lado, quando a razão de equivalência é maior do que um a mistura é rica em combustível e consequentemente haverá falta de ar para que a combustão seja alcançada em proporções estequiométricas. Eventualmente se a razão de equivalência for igual a um, a mistura é considerada estequiométrica e com isso não há nem excesso, nem falta de ar ou de combustível.

É importante mencionar que o fator lambda $(\lambda)$ também é um parâmetro frequentemente utilizado para expressar o quão rica ou pobre uma mistura ar/combustível pode ser. O fator lambda é dado pelo inverso da razão de equivalência $\left(\lambda=\phi^{-1}\right)$. Em outras palavras, a mistura é dita rica em combustível quando o fator lambda é inferior a um e pobre para valores superiores a um.

\section{6}

\section{Eficiências}

No estudo do desempenho característico de uma máquina térmica frequentemente utilizam-se eficiências como parâmetros fundamentais para as avaliações. Nos motores de combustão interna destacam-se neste trabalho: eficiência térmica $\left(\eta_{\mathrm{t}}\right)$, eficiência térmica do etanol em mistura ternária $\left(\eta_{\mathrm{tE}-\mathrm{DBE}}\right) \mathrm{e}$ eficiência volumétrica $\left(\eta_{\mathrm{v}}\right)$.

O rendimento térmico de um motor a combustão interna é um parâmetro que quantifica a capacidade do equipamento em converter a energia química contida no combustível em trabalho de eixo ou ainda, a eficiência térmica representa a relação entre a potência efetiva produzida, a vazão de combustível 
e seu poder calorífico. Logo, a relação que determina o rendimento térmico ou a eficiência térmica $\left(\eta_{t}\right)$ pode ser dada pela eq. (14) [1]:

$$
\eta_{t}=\frac{3,6 P_{b}}{\dot{m}_{c} P C i}=\frac{3,6}{\operatorname{cec} P C i}
$$

Em que:

$\eta_{t} \quad$ : eficiência térmica (-);

$P_{b} \quad$ : potência efetiva $(\mathrm{kW})$;

$\dot{m}_{c} \quad$ : vazão mássica de combustível $(\mathrm{kg} / \mathrm{h})$;

$\mathrm{PCi} \quad$ : poder calorífico inferior do combustível ou da mistura $(\mathrm{MJ} / \mathrm{kg})$.

No entanto, o conceito de rendimento térmico não se limita à estimativa da eficiência térmica da mistura como um todo, mas pode também estender-se ao estudo específico do comportamento de um dos componentes de misturas como, por exemplo, o etanol.

Assim como apresentado na eq. (7) para o consumo específico energético de etanol em mistura, também está elaborada nesta dissertação uma formulação para a estimativa da parcela de eficiência térmica correspondente à presença do etanol em mistura ternária $\left(\eta_{\mathrm{tE}-\mathrm{DBE}}\right)$. As manipulações algébricas deste parâmetro consideram a relação entre o conceito da eficiência térmica $\left(\eta_{t}\right)$ associado às participações ponderadas do etanol e do restante dos componentes da mistura.

Vale destacar que, na prática dos testes realizados, as misturas sem a presença de etanol resumem-se às avaliações com combustível B15E0. Por isso, as misturas B15E0 servem como base para os cálculos da eficiência térmica do etanol em mistura ternária, em função das condições de torque e rotação testadas. A eficiência térmica do etanol em uma mistura ternária pode ser representada pela eq. (15):

$$
\eta_{t E-D B E}=\frac{3,6 P_{b}-\eta_{t B 15 E 0} \dot{m}_{c B 15 E 0} P C i_{B 15 E 0}}{\dot{m}_{c E} P C i_{E}}
$$

A expressão da eq. (15) mostra, portanto, que a eficiência térmica do etanol na mistura baseia-se numa razão em que o numerador é a potência relativa à presença de etanol na mistura - determinada pela diferença entre a potência total entregue pela mistura e a potência dada por B15E0 - e o denominador é a parcela de energia química de etanol presente na mistura.

Em que, para cada condição de torque e rotação específica, tem-se:

$\eta_{t E-D B E} \quad$ : eficiência térmica do etanol em mistura ternária (-); 


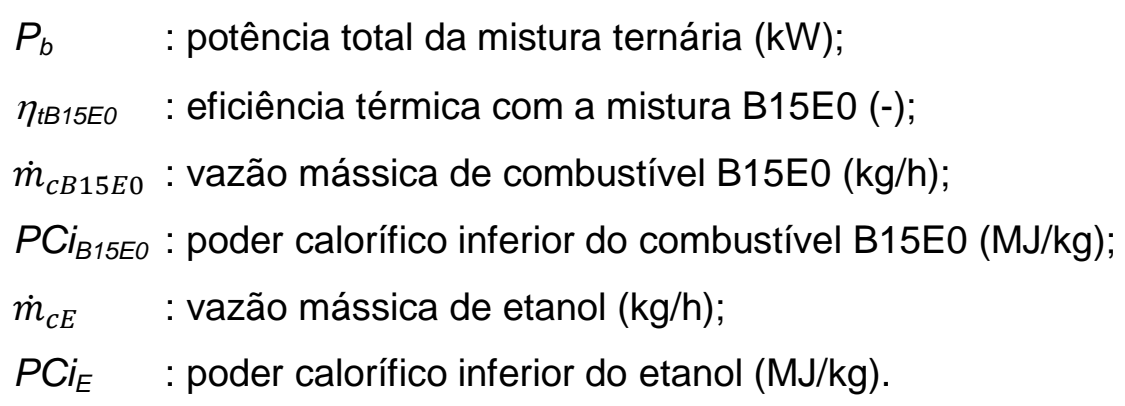

A eficácia do processo de indução de um gás (e.g.: ar) em um compressor, que também ocorre na etapa de admissão para compressão da carga de um motor a combustão interna, é dada pelo parâmetro da eficiência volumétrica $\left(\eta_{\mathrm{v}}\right)$. Portanto, no caso do motor a combustão interna esta eficiência é definida pela relação entre vazão mássica de ar admitido e taxa de volume deslocado pelo pistão. Sucintamente, a eficiência volumétrica representa a razão entre volume admitido para a compressão e volume deslocado pelo movimento do pistão, conforme mostra a eq. (16) para motor de quatro tempos e quatro cilindros:

$$
\eta_{v}=\frac{2 \dot{m}_{a r, s}}{\rho_{a r, s} 4 V_{d} 60 N}
$$

Em que:

$\eta_{v} \quad$ : eficiência volumétrica (-);

$\dot{m}_{a r, s} \quad$ : vazão mássica de ar seco $(\mathrm{kg} / \mathrm{h})$;

$\rho_{a r, s} \quad$ : massa específica do ar seco $\left(\mathrm{kg} / \mathrm{m}^{3}\right)$;

$V_{d} \quad$ : volume deslocado $\left(\mathrm{m}^{3}\right) ;$

$N \quad$ : velocidade angular (RPM).

Considerando hipoteticamente o ar como um gás ideal, calcula-se a massa específica do ar ambiente pela lei dos gases ideais, conforme a eq. (17):

$$
\rho_{a r, s}=\frac{p_{a r, s}}{R_{a r, s} T_{a m b}}
$$

Em que:

$\rho_{\text {ar }, s} \quad$ : massa específica do ar seco $\left(\mathrm{kg} / \mathrm{m}^{3}\right)$;

$p_{a r, s} \quad$ : pressão do ar seco (kPa) (Apêndice B - eq. (B.5));

$R_{a r, s} \quad$ : constante do ar seco $(\mathrm{kJ} / \mathrm{kgK})$;

$T_{a m b} \quad$ : temperatura do ar ambiente $(\mathrm{K})$. 


\section{7 \\ Relação Politrópica}

A estimativa do valor da pressão no motor, quando não há a ocorrência de combustão, pode ser obtida admitindo-se o ciclo do motor como um processo de compressão e expansão de gases ideais. Com isso, é possível estabelecer o modelo de gás ideal através da relação politrópica da eq. (18). Esta relação permite que não somente pressões, mas também volumes ou até mesmo temperaturas (através de manipulação algébrica) de estados termodinâmicos possam ser associadas pelo uso de um expoente politrópico ao longo dos cursos de compressão e expansão.

$$
p V^{n}=\text { constante }
$$

Em que:

$p \quad$ : pressão $(\mathrm{Pa})$;

$V \quad$ : volume $\left(\mathrm{m}^{3}\right)$;

$n \quad$ : expoente politrópico.

A eq. (18) pode ser reescrita de forma a evidenciar as relações entre as pressões e volumes nos estados termodinâmicos iniciais e finais do processo da compressão politrópica, conforme indica a eq. (19):

$$
\frac{p_{f}}{p_{i}}=\left(\frac{V_{i}}{V_{f}}\right)^{n}=(R C)^{n}
$$

Em que:

$p_{i} \quad$ : pressão no início da compressão $(\mathrm{kPa})$;

$p_{f} \quad$ : pressão no final da compressão $(\mathrm{kPa})$;

$V_{i} \quad$ : volume no início da compressão $\left(\mathrm{m}^{3}\right)$;

$V_{f} \quad$ : volume no final da compressão $\left(m^{3}\right)$;

$R C$ : razão de compressão.

Porém os cálculos e estimativas de pressões e volumes a partir da relação politrópica dependem do expoente politrópico, o qual pode tomar valores ligeiramente diferenciados ao longo dos processos termodinâmicos, refletindo as características destes processos. Segundo Heywood [1], o expoente para combustíveis convencionais pode variar em uma faixa de valores entre 1,25 e 1,35 nos processos de compressão e expansão politrópicas. 
Geralmente, na situação inicial da compressão, a temperatura dos gases admitidos costuma ser menor do que a temperatura das paredes, conduzindo a um aquecimento dos gases/mistura que se manifesta através de um expoente politrópico maior do que a relação de calores específicos dos gases/mistura $(n>\gamma$, em que $\left.\gamma=c_{p} / c_{v}\right)$. O aumento de pressão resultante do procedimento de compressão, à medida que o pistão desloca-se em direção ao TDC, contribui para a elevação da temperatura da mistura. Com isto, há uma gradual redução da troca de calor entre as paredes do cilindro e a mistura, até acontecer a inversão no sentido da transferência de calor, quando a temperatura da mistura supera a temperatura das paredes do cilindro (neste caso o expoente politrópico se torna menor que a relação dos calores específicos da mistura $-\mathrm{n}<\gamma$ ).

\section{8}

\section{Aplicação da Primeira Lei da Termodinâmica}

À luz dos princípios da Primeira Lei da Termodinâmica, é possível delinear fenômenos que ocorrem na câmara, bem como fundamentar avaliações sobre processos termodinâmicos da combustão.

Para qualquer análise termodinâmica é essencial que sejam definidos os volumes que serão considerados durante o processo e explicitar como ocorre sua interação com o meio externo. Portanto, na avaliação de um motor a combustão interna, considera-se a região em que se desenvolvem os processos termodinâmicos como um volume de controle, no qual algumas hipóteses também devem ser consideradas para estudos específicos. É possível citar como exemplo a avaliação em fase aberta (admissão, compressão, combustão, expansão e exaustão), assim como a avaliação em fase fechada do ciclo (compressão, combustão e expansão). Neste trabalho considera-se a fase fechada: compressão (após o fechamento das válvulas de admissão), combustão e exaustão (até o instante de abertura das válvulas de escape).

A apropriada delimitação do volume de controle e das fronteiras por onde a massa de combustível deve cruzar são fundamentais para o esclarecimento do conteúdo teórico que se segue. Logo, a Figura 25 [24] esboça o volume de controle a ser estudado, o qual permite fluxo de massa de ar e combustíveis através de suas fronteiras, porém as válvulas de admissão e escape são mantidas fechadas nos instantes analisados. 


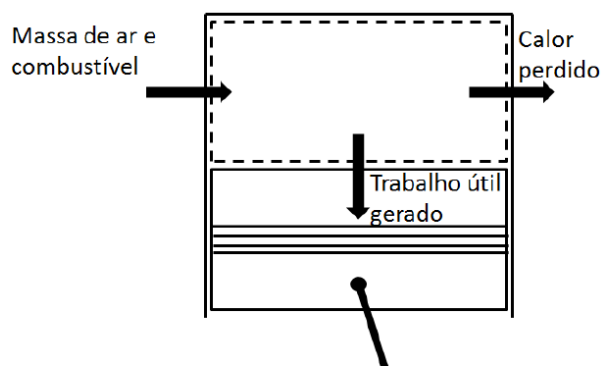

Figura 25 - Volume de controle com válvulas fechadas

Então, supondo-se condições hipotéticas de fluido de trabalho (mistura entre ar e combustíveis) representado como gás ideal, distribuição inteiramente uniforme de pressão e temperatura na câmara e desprezando-se os efeitos das regiões de deposição (que na realidade podem não ser tão desprezíveis) no volume de controle e não uniformidades na mistura de ar, combustível e gases residuais, pode-se aproximar a Primeira Lei da Termodinâmica para volume de controle para funcionamento via ignição por compressão com injeção direta de combustível à expressão da eq. (20), sugerida no livro de Heywood [1]:

$$
\frac{d Q}{d \theta}-p \frac{d V}{d \theta}+\dot{m}_{D} h_{D}+\dot{m}_{E} h_{E}=\frac{d U}{d \theta}
$$

Em que:

$\frac{d Q}{d \theta} \quad$ : taxa de transferência de calor $(\mathrm{kW})$;

$p \frac{d V}{d \theta} \quad$ : potência realizada $(\mathrm{kW})$;

$h \quad$ : entalpia do combustível injetado $(\mathrm{kJ} / \mathrm{kg})$;

$\frac{d U}{d \theta} \quad$ : taxa de variação da energia interna $(\mathrm{kW})$.

Além dos termos apresentados acima, é importante esclarecer que os índices "D" e "E" fazem referência ao diesel e etanol, respectivamente.

O primeiro termo à esquerda da eq. (20), traduzido como taxa de transferência de calor no volume de controle, é conhecido também como a taxa de liberação de calor aparente e pode ser mais detalhadamente interpretado pela diferença entre calor liberado na combustão dos combustíveis e transferências de calor do volume de controle (pelas paredes, cabeçote e etc.). É possível ainda reescrever a eq. (20) desprezando os termos relativos ao trabalho de fluxo, haja vista que os valores das entalpias nestes casos possam ser aproximados à zero, como mais uma vez sugere Heywood [1] na eq. (21):

$$
\frac{d Q}{d \theta}-p \frac{d V}{d \theta}=\frac{d U}{d \theta}
$$


Considerando-se que o conteúdo no interior do cilindro possa ser modelado como gás ideal, é possível aplicar a equação de estado da eq. (22) e ainda aproveitar a diferenciação da definição de calor específico a volume constante da eq. (23) para que, após a diferenciação da eq. (22) e algumas manipulações algébricas das equações - conforme o equacionamento desenvolvido em detalhes na dissertação de Ferrari Filho [24] -, seja alcançada a eq. (24), que é recomendável para diversas aplicações na engenharia relacionadas à análise de combustões de ignição por compressão, segundo aponta o livro de Heywood [1].

$$
\begin{gathered}
p V=m R T \\
\frac{d U}{d \theta}=m c_{v} \frac{d T}{d \theta} \\
\frac{d Q}{d \theta}=\frac{\gamma}{\gamma-1} p \frac{d V}{d \theta}+\frac{1}{\gamma-1} V \frac{d p}{d \theta}
\end{gathered}
$$

Em que:

$$
\begin{array}{ll}
m & : \text { massa da mistura }(\mathrm{kg}) ; \\
R & : \text { constante universal dos gases }(\mathrm{kJ} / \mathrm{kgK}) ; \\
T & : \text { temperatura }(\mathrm{K}) ; \\
C_{V} & : \text { calor específico a volume constante }(\mathrm{kJ} / \mathrm{kgK}) ; \\
\gamma & : \text { razão entre calores específicos. }
\end{array}
$$

Nesta dissertação, a aplicação da expressão apresentada na eq. (24) não se restringirá a ignição por compressão com combustível diesel, mas será estendida para as estimativas da taxa de calor liberado na operação com misturas ternárias (diesel, biodiesel e etanol), até porque neste caso a ignição também acontece pela compressão. Contudo, é prudente reforçar a hipótese simplificadora que avalia a mistura dos gases no interior da câmara como homogênea, pois esta continua sendo necessária para corroborar com o uso da expressão para aproximações da taxa de liberação de calor aparente.

Algumas propriedades dos gases podem variar bastante durante todo o processo de combustão como, por exemplo, a razão entre calores específicos $(\gamma)$ que se altera em função da temperatura. Existem modelos sofisticados capazes de modelar propriedades dos gases no interior do cilindro antes, durante e após a combustão. Todavia também há relações sucintas e eficazes como a apresentada pela eq. (25) que se revela como um artifício para a estimativa do valor da razão entre os calores específicos em função da temperatura através da expressão da eq. (26), segundo Crowell [117]. 


$$
\begin{gathered}
\gamma=\left(1-\frac{R}{c_{p}}\right)^{-1} \\
\frac{c_{p}}{R}=A_{0}+A_{1} T+A_{2} T^{2}+A_{3} T^{3}+A_{4} T^{4}
\end{gathered}
$$

Em que:

$c_{p} \quad$ : calor específico a pressão constante $(\mathrm{kJ} / \mathrm{kgK})$;

$A_{0} \quad$ : 3,04473 (constante);

$A_{1} \quad: 1,33805 \times 10^{-3}\left(\mathrm{~K}^{-1}\right)$;

$A_{2} \quad:-4,88256 \times 10^{-7}\left(\mathrm{~K}^{-2}\right)$;

$A_{3} \quad: 8,55475 \times 10^{-11}\left(\mathrm{~K}^{-3}\right)$

$A_{4} \quad:-5,70132 \times 10^{-15}\left(\mathrm{~K}^{-4}\right)$.

Por sua vez, a temperatura também é uma incógnita neste sistema de equações. O cálculo desta variável, porém, é possível amarrando-se algumas condições para a utilização da lei dos gases ideais. Algumas premissas relevantes para a simplificação da modelagem da estimativa de temperatura são: adotar o modelo de gás ideal para o processo, desprezar efeitos decorrentes da eventual presença de resquícios de combustível no interior do cilindro e definir a massa de gás que participa do processo como constante. Em outras palavras, para a estimativa de temperatura ao longo do processo deve-se aproximar o conjunto a um sistema termodinâmico.

Desta maneira, conhecendo as condições iniciais de pressão, temperatura de admissão, assim como o volume no ponto morto inferior (BDC), torna-se viável a obtenção da temperatura em outro instante qualquer do processo de compressão, dados o volume e a pressão neste ponto, conforme indicado pela eq. (27):

$$
T_{n}=\frac{p_{n} V_{n} T_{i}}{p_{i} V_{i}}
$$

Em que:

$p_{i} \quad$ : pressão na admissão $(\mathrm{kPa})$;

$p_{n} \quad$ : pressão em um instante $\mathrm{n}$ qualquer $(\mathrm{kPa})$;

$V_{i} \quad$ : volume no ponto morto inferior $\left(\mathrm{m}^{3}\right)$;

$V_{n} \quad:$ volume em um instante $n$ qualquer $\left(\mathrm{m}^{3}\right)$;

$T_{i} \quad$ : temperatura na admissão (K);

$T_{n} \quad$ : temperatura em um instante $\mathrm{n}$ qualquer $(\mathrm{K})$.

Complementando a análise termodinâmica envolvida no processo de 
combustão desenvolvida neste item da dissertação, a estimativa do calor liberado é um parâmetro capaz de fundamentar comparações, no âmbito energético, entre as misturas avaliadas. A obtenção do calor liberado total durante a combustão é dada pela integração, realizada de forma iterativa, da taxa de liberação de calor aparente em função do ângulo de virabrequim durante todo o processo, conforme a eq. (28):

$$
Q=\int \frac{d Q}{d \theta} d \theta
$$

Em que:

Q : calor liberado $(\mathrm{kJ})$;

$\frac{d Q}{d \theta} \quad$ : taxa de transferência de calor $(\mathrm{kW})$;

$d \theta \quad$ : intervalo infinitesimal de ângulo de virabrequim $\left(^{\circ}\right)$.

\section{9}

\section{Atraso da Ignição}

O atraso da ignição configura-se como um parâmetro de extrema relevância para o fenômeno da combustão nos processos de ignição por compressão, conforme já mencionado no item 2.1. Todavia, a complexidade na determinação do valor do atraso de ignição é um ponto a ser destacado, justificado pela dificuldade na definição do instante de início da combustão. Portanto, existem alguns métodos de estimativa do atraso da ignição, os quais podem ser divididos em duas categorias: métodos diretos e métodos indiretos.

O método direto consiste na medida da posição da chama em função do tempo, através de artifícios visuais. Por isso este método, geralmente, exige adaptações na câmara de combustão a fim de que uma janela de quartzo (transparente) permita a visualização e o registro do processo de combustão por intermédio de uma câmera de alta velocidade. A referida medição de posição da chama em função do tempo (método direto) também é possível pela utilização de detector de ionização de chama e seus demais componentes eletrônicos associados. Por outro lado, a aplicação do método direto nem sempre é trivial, então alternativamente ao método direto, o método indireto recorre às curvas de pressão das combustões. O sensor de pressão, posicionado no cabeçote, encarrega-se de registrar precisamente as pressões em função do tempo. Levando-se em conta as curvas de pressão e com uma análise crítica razoável sobre o assunto, é viável avaliar qualitativamente o atraso da ignição e sua duração, no entanto este tipo de estimativa não apresenta muita precisão, já que 
os dados de pressão não são capazes de fornecer diretamente os parâmetros relacionados à combustão. Por isso, alguns autores recomendam o uso das curvas de pressão como inputs em estudos sobre o atraso da ignição que assegurem melhores resultados em termos quantitativos ou, em outras palavras, soluções mais precisas. Dentre as sugestões, pode-se listar:

- Derivadas da curva de pressão: refere-se à utilização da primeira $(d p / d t)$, segunda $\left(d^{2} p / d t^{2}\right)$ e até mesmo terceira $\left(d^{3} p / d t^{3}\right)$ derivadas da curva de pressão em relação ao tempo para a determinação do atraso da ignição. Esta estratégia permite aliar a derivação matemática às medições de pressão durante o fenômeno da combustão para evidenciar o instante de seu início pelas variações na curva de pressão ao longo do processo [118];

- Curva de liberação de calor: diz respeito à estimativa do início da combustão através da utilização da curva de calor liberado. Neste caso, definese o início da combustão quando o valor acumulado na curva de liberação de calor atinge entre $3 \%$ e $5 \%$ de seu total [119];

- Curvas logarítmicas de pressão e volume: nesta situação o coeficiente angular da porção retilínea da compressão determina o coeficiente politrópico médio até o trecho onde ocorre o desvio desta trajetória retilínea, indicando o início da combustão [120].

Nesta dissertação o início da combustão é estimado mediante a avaliação de derivadas das curvas de pressão (conforme exemplificado pela terceira derivada da pressão na Figura 26, em que o pico da curva indica o início da combustão), tornando o método de determinação para o atraso da ignição compatível com aquele utilizado por Egúsquiza em sua tese de doutorado [31].

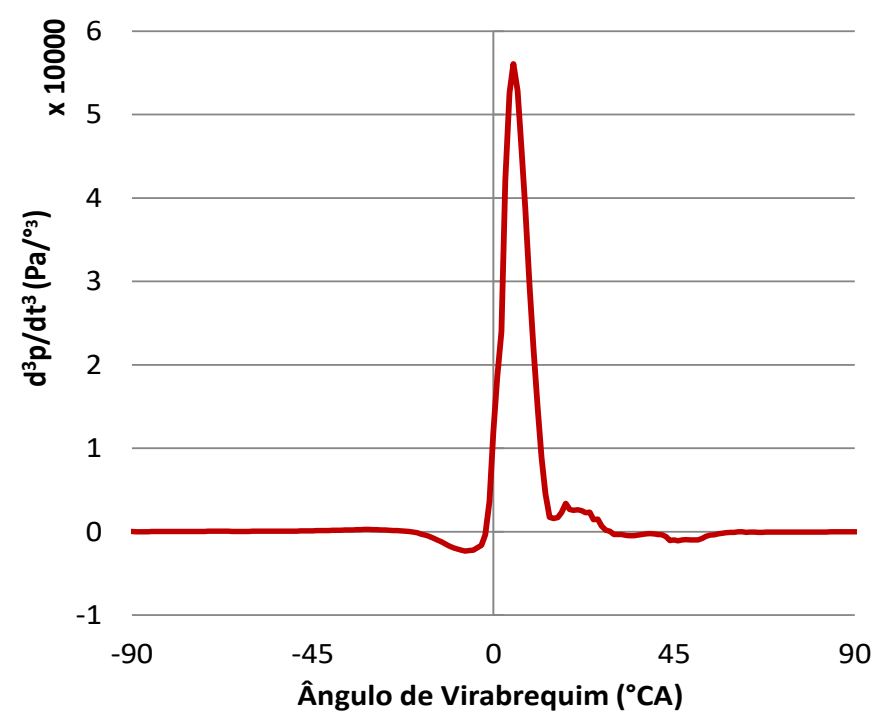

Figura 26 - Exemplo de curva da terceira derivada da pressão 


\section{5 \\ Resultados e Discussões}

Neste capítulo, apresentam-se os resultados obtidos nos testes executados para o cumprimento dos objetivos propostos incialmente por este trabalho, bem como os comentários pertinentes ao conteúdo a ser exibido.

A organização deste capítulo é dada pela divisão em três principais etapas. A primeira parte apresenta resultados de ensaios iniciais em que cada uma das seis misturas (B7, B15E0, B15E5, B15E10, B15E15 e B15E20) é testada com apenas um avanço para a injeção de combustível (10,5 BTDC), sempre segundo as combinações de pares de torque versus rotação listadas na Tabela 4 do item de procedimento experimental (3.5). Na sequência do capítulo exibem-se os estudos relacionados à busca dos instantes de injeção que maximizem o desempenho do motor com misturas sujeitas à presença de etanol. Por último, são mostrados resultados com enfoque no desempenho e comportamentos característicos de misturas com etanol em pontos de injeção ótimos.

\section{1}

\section{Avaliações com Avanços de Injeção Fixos}

Nestas avaliações iniciais, com instante de injeção fixado em 10,5 BTDC, a intenção é mostrar o desempenho e comportamento das combustões de cada mistura sob um mesmo instante de injeção de combustível, salientando-se a influência da presença do etanol e justificando investigações dos instantes de injeção das misturas com etanol, presentes na segunda etapa deste capítulo.

Vale destacar que para o estabelecimento das condições de torque de referência em função de cargas máximas alcançadas com o combustível B7, conforme a definição da Tabela 4, os primeiros testes que se fazem necessários são, portanto, aqueles com este combustível.

\subsection{1}

\section{Definição das Combinações de Torque e Rotação}

A definição dos pares de torque e rotação é o resultado mais preliminar de todos, uma vez que representa o primeiro contato com os parâmetros que estão sendo fixados para as demais análises. Conforme descrito na Tabela 4, as 
porcentagens (de $25 \%$ e $50 \%$ ) dos torques máximos alcançados com o diesel B7 estabelecem as condições de referência para as demais misturas a serem testadas. A Tabela 7 abaixo mostra os resultados obtidos para torque e rotação com o combustível B7 (diesel comercial), além de valores de BMEP, IMEP e potência efetiva, os quais também são parâmetros que sofrem influência direta das combinações de torque e rotação selecionadas, mas não devem se alterar de acordo com a mistura utilizada.

Tabela 7 - Condições de referência com o combustível B7

\begin{tabular}{|c|c|c|c|c|c|}
\hline $\begin{array}{c}\text { Rotação } \\
\text { (RPM) }\end{array}$ & $\begin{array}{c}\text { Torque de B7 } \\
(\%)\end{array}$ & $\begin{array}{c}\text { Torque } \\
\text { (Nm) }\end{array}$ & $\begin{array}{c}\text { Potência } \\
\text { (kW) }\end{array}$ & $\begin{array}{c}\text { BMEP } \\
\text { (Bar) }\end{array}$ & $\begin{array}{c}\text { IMEP } \\
\text { (Bar) }\end{array}$ \\
\hline & $25 \%$ & 81,2 & 12,8 & 2,4 & 4,2 \\
\hline 1500 & $50 \%$ & 161,9 & 25,5 & 4,7 & 6,9 \\
& $100 \%$ & 327,2 & 51,5 & 9,6 & 12,7 \\
\hline \multirow{2}{*}{1800} & $25 \%$ & 96,5 & 18,2 & 2,8 & 5,3 \\
\hline & $50 \%$ & 193,4 & 36,4 & 5,6 & 8,4 \\
\hline \multirow{2}{*}{2100} & $100 \%$ & 387,7 & 73,1 & 11,3 & 15,3 \\
\hline & $25 \%$ & 90,0 & 19,8 & 2,6 & 5,4 \\
\hline & $50 \%$ & 180,3 & 39,6 & 5,3 & 8,5 \\
\hline & $100 \%$ & 359,1 & 78,9 & 10,5 & 14,6 \\
\hline
\end{tabular}

No Anexo $D$ encontram-se disponíveis os resultados dos testes com cada combustível e avanço da injeção fixado em 10,5 BTDC. Os valores da tabela apresentada no Anexo D comprovam que em todos os casos houve condições de se atingir números bem próximos dos $25 \%$ e $50 \%$ referentes aos torques máximos de combustível B7 definidos na Tabela 7. No entanto, dentre os torques, potência, BMEP e IMEP apresentados neste anexo, nota-se que nas condições máximas de operação há nítidas reduções destes valores quanto maior é a presença de etanol nas misturas.

À primeira vista, imagina-se que quedas nos desempenhos máximos em função do aumento da proporção de etanol nas misturas justificar-se-iam pelos maiores retardos no início da combustão com crescentes participações de etanol nas misturas com o instante de injeção fixado. Porém, a Figura 27 suscita a suspeita de que as perdas de desempenho atribuídas às características de combustão do etanol tenham se potencializado além de um limite razoável. Constata-se, então, que a presença de etanol não é o único fator a causar as diminuições observadas, haja vista as disparidades da Figura 27 entre as condições máximas operacionais para cada combustível avaliado. 


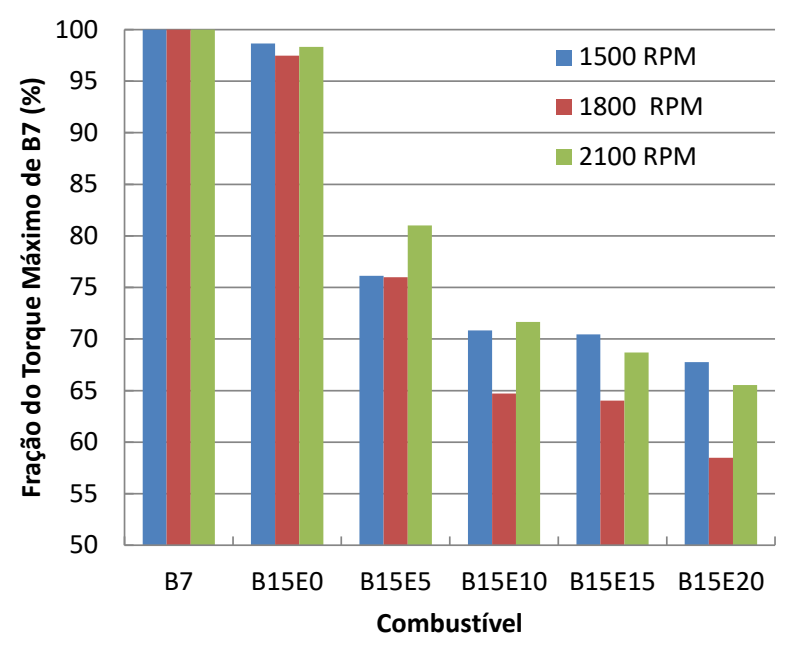

Figura 27 - Frações alcançadas do torque máximo de B7

Com isso, decidiu-se investigar também a capacidade de injeção da bomba através da estimativa do volume de combustível injetado por: dados de vazão mássica de combustível e rotação do motor. A Figura 28 revela que, de fato, a bomba injetora utilizada (original do motor testado) perde capacidade de injeção quando exposta a misturas com etanol. O volume injetado das misturas com etanol, devido ao menor poder calorífico deste álcool, deveria ser maior do que aquelas sem etanol para a obtenção de um mesmo nível de torque. Contudo o oposto ocorreu e registraram-se injeções de combustível em quantidades até $31 \%$ inferiores.

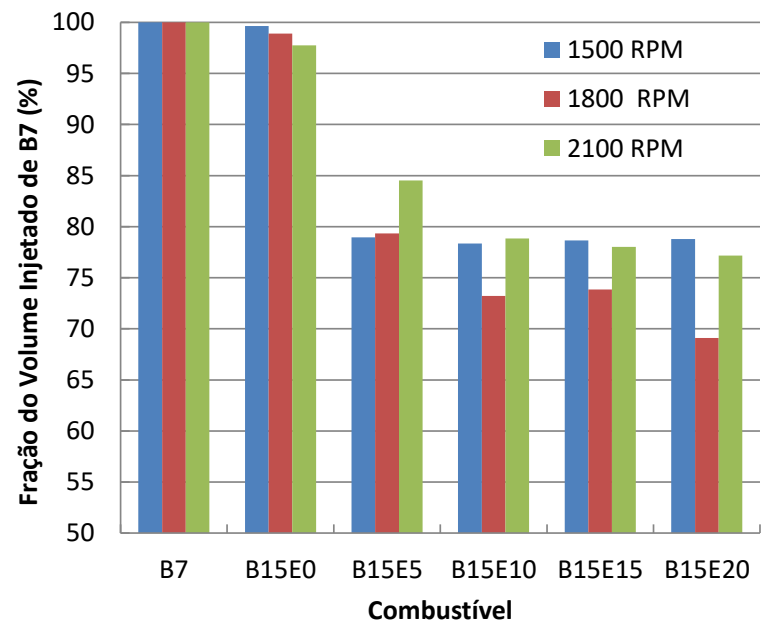

Figura 28 - Volume injetado nas condições operacionais máximas

A incapacidade de injetar a quantidade de volume de combustível desejada, e consequentemente de energia, mostra-se sensível à presença de etanol nas misturas e se acentua com o aumento das proporções injetadas do álcool. Em outras palavras, a perda na injeção já se torna pronunciada desde a 
menor participação de etanol nas misturas ternárias avaliadas (B15E5) e apenas se evidencia mais com o crescimento da introdução deste álcool nas misturas.

Apesar da limitação na injeção de combustível, constatada nas operações em condições máximas para as misturas ternárias, é compreensível que a presença de etanol prejudique o funcionamento adequado da bomba, uma vez que as propriedades de viscosidade e lubricidade deste álcool são bem distintas do óleo diesel, combustível para o qual esta bomba é projetada. Cabe ressaltar que Hansen et al. [75] haviam comentado anteriormente sobre os prejuízos à capacidade de bombeio que as menores viscosidades de misturas com etanol poderiam causar.

Em última análise, o gargalo imposto pela bomba injetora de combustível não chega a comprometer as comparações entre as diferentes misturas nas condições de $25 \%$ e $50 \%$ dos torques máximos de B7 desta dissertação, mas sinaliza restrições e cuidados necessários nas operações em condições máximas - ou mesmo em cargas moderadas a elevadas - com esta bomba injetora quando o motor é abastecido com misturas com etanol. Inclusive, estas mesmas peculiaridades na operação da bomba com a presença de etanol também foram notadas durante os testes de Pradelle [14] no motor.

\section{1 .2 \\ Desempenho do Motor}

A investigação do desempenho do motor é importante para elucidar o desenvolvimento das conversões energéticas dentro da câmara de combustão. Os valores de $25 \%$ e $50 \%$ do torque máximo de B7 para cada rotação definida na metodologia estão exibidos na Tabela 7. Nos testes com os demais combustíveis, procura-se também atingir os valores de $25 \%$ e $50 \%$ do torque máximo de B7 da Tabela 7, conforme apresentado no Anexo D.

Desta forma, a rotação e o torque são parâmetros impostos às condições experimentais e funcionam como dados de entrada nas avaliações de performance do motor. Por outro lado, vazão de ar admitido, vazão de combustível e até mesmo percentual de pedal de acelerador são parâmetros que funcionam como dados de saída dos testes, indicando o desempenho do motor através de conjuntos de resultados, tais como: consumo específico de combustível e eficiência térmica, por exemplo.

O fator lambda $(\lambda)$ é um parâmetro que mostra como ocorre o preparo da mistura ar/combustível antes do processo de conversão energética na câmara de combustão. Este parâmetro indica, em função da estequiometria do 
combustível avaliado, o quão rica ou pobre é a carga contida no interior do cilindro. Portanto, os resultados da Figura 29 não mostram diretamente informações sobre o desempenho das conversões energéticas do motor, mas revelam demandas do motor por ar e combustível na obtenção das condições operacionais determinadas para esta dissertação.
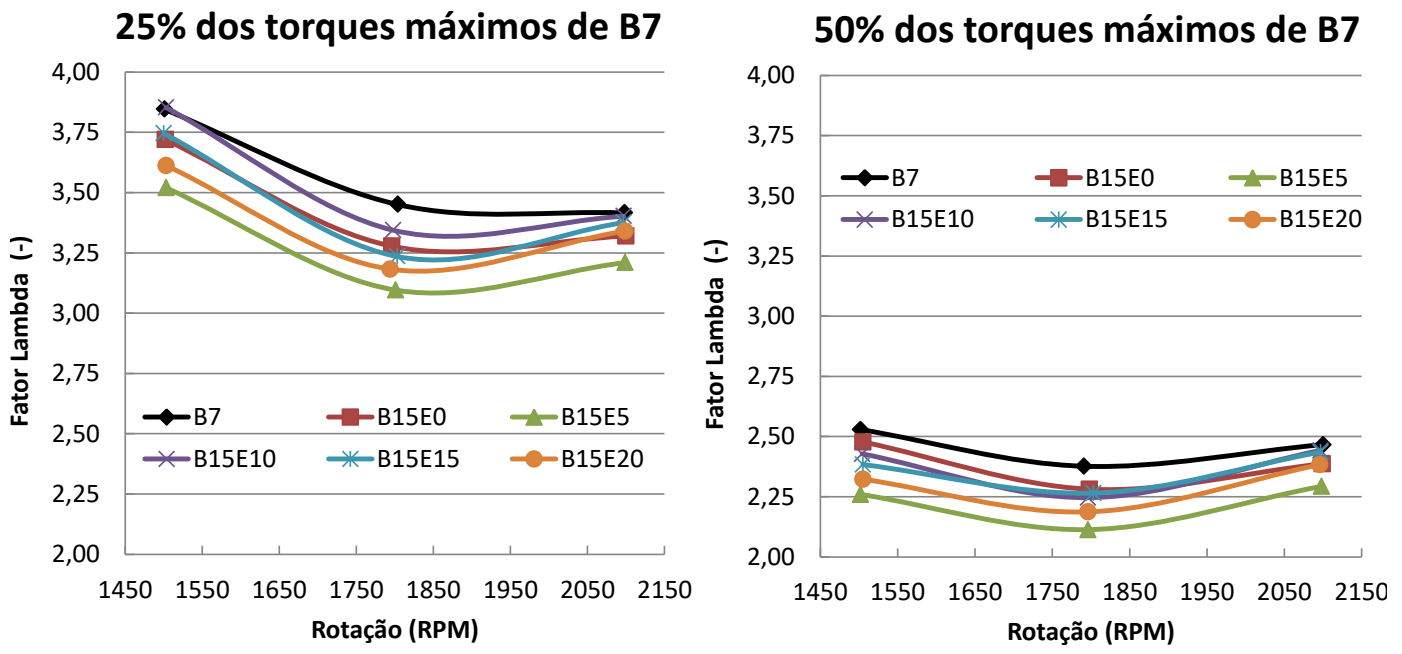

Figura 29 - Fator lambda - avanço de 10,5 BTDC

Os resultados para o fator lambda, apresentados na Figura 29, mostram-se inferiores na situação de $50 \%$ dos torques máximos de B7, fato que é previsível, visto que maiores quantidades de combustível são necessárias à formação de misturas mais ricas em combustível e, por conseguinte, para que sejam alcançados os torques desta condição experimental.

Além disto, nota-se que as curvas exibidas se deslocam em até aproximadamente $10 \%$ do fator lambda exibido para o diesel B7. Isto mostra que combustíveis distintos exigem, para a manutenção das condições experimentais desejadas, diferentes razões entre ar e combustível. A tendência de redução do fator lambda com a crescente participação do etanol nas misturas fornece os primeiros indícios práticos sobre a relevância do estudo dos efeitos deste álcool em misturas ternárias e do instante da injeção de combustível.

Já o consumo específico de combustível (cec) é um resultado intrinsecamente associado ao desempenho da conversão energética da combustão. Esta variável indica a massa necessária $(\mathrm{kg})$ de determinado combustível para a obtenção de uma única unidade de energia de trabalho fornecido pelo motor (kWh). Com isso, os valores da Figura 30 relacionam vazão mássica de combustível e potência entregue sem, contudo, levar em conta o poder calorífico dos combustíveis. 
25\% dos torques máximos de B7

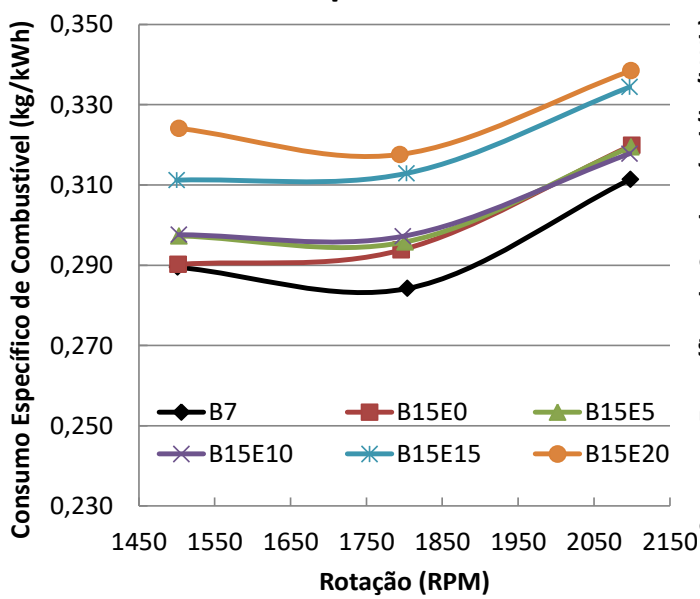

$\mathbf{5 0 \%}$ dos torques máximos de B7

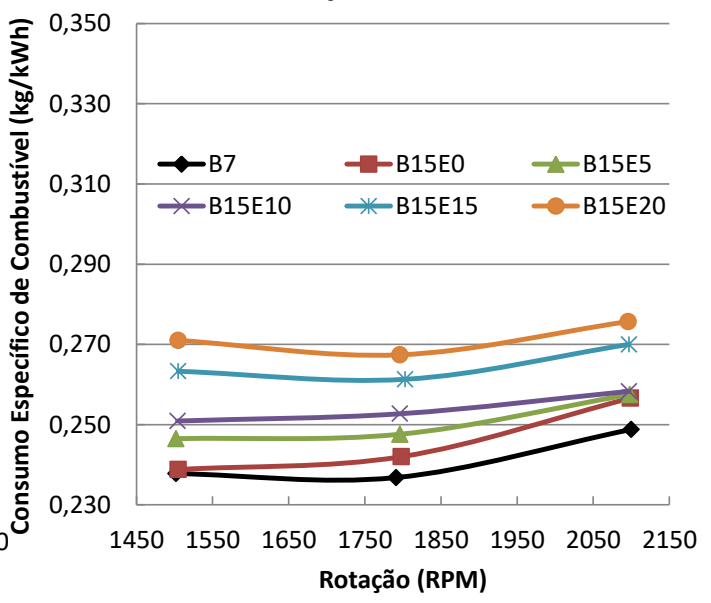

Figura 30 - cec - avanço de 10,5 BTDC

O poder calorífico inferior é uma propriedade física que decresce conforme há o aumento da presença de etanol nas misturas. Portanto, é perfeitamente compreensível que o diesel comercial B7 comporte-se melhor que os demais combustíveis, ou seja, é coerente que seja necessária uma menor massa de combustível para geração de uma unidade de energia em um motor abastecido com diesel comercial B7, em razão do poder calorífico mais elevado deste combustível frente às outras misturas testadas.

A diferença entre a faixa de valores para consumo específico de combustível nas condições de $25 \%$ e $50 \%$ dos torques máximos de B7 também é um comportamento a ser destacado. Os menores consumos específicos de combustível, que são sinônimos de melhores resultados, para a condição de torque mais elevado são evidências de que a conversão da energia do combustível em trabalho (ou potência) acontece mais eficientemente nas operações a $50 \%$ do que a $25 \%$ dos torques máximos de $\mathrm{B} 7$.

Assim como o consumo específico de combustível, a eficiência térmica também é capaz de descrever os fenômenos que ocorrem no motor em termos de sua performance energética. Este parâmetro avalia a energia disponibilizada pelo motor em forma de trabalho a partir da energia química contida na massa de combustível injetada na câmara de combustão, conforme indicam os resultados apresentados pela Figura 31.

Portanto, a eficiência térmica proporciona mais equilíbrio às análises das conversões energéticas em que, simultaneamente, combustíveis de diferentes poderes caloríficos são estudados, visto que nestas situações as massas de combustível não armazenam as mesmas quantidades de energia. 

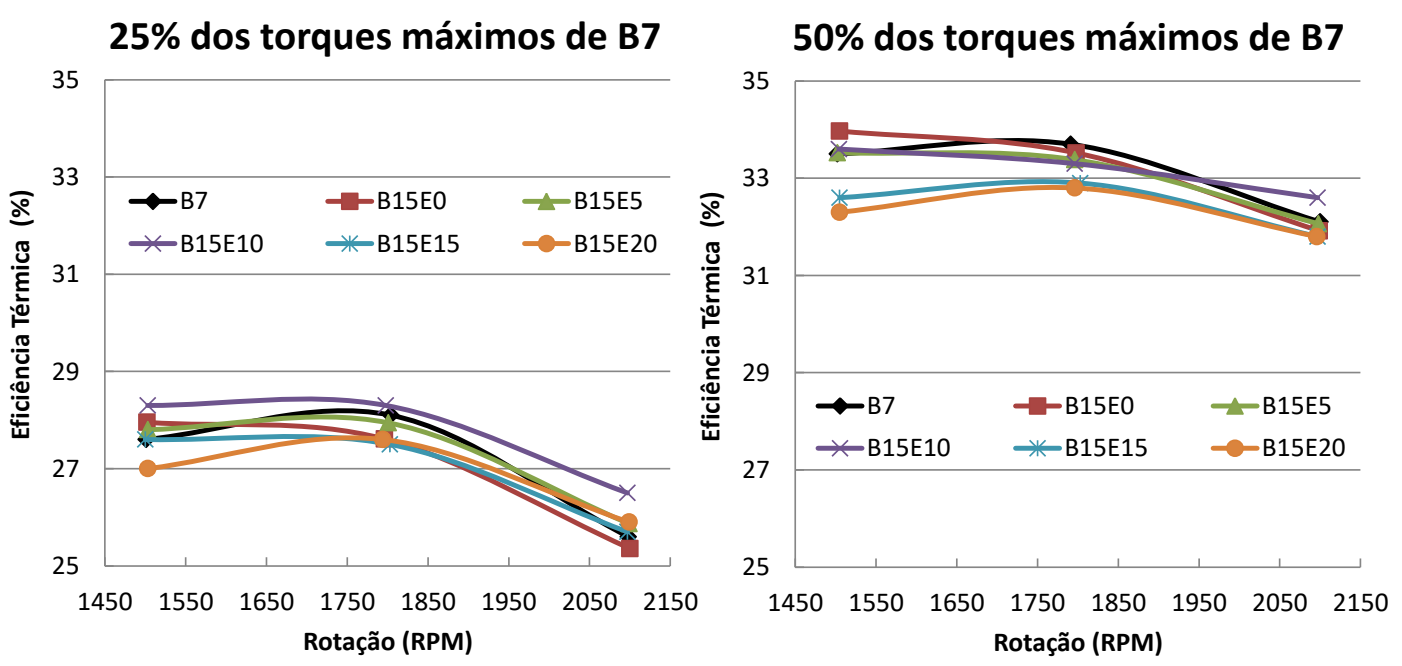

Figura 31 - Eficiência Térmica - avanço de 10,5 BTDC

As curvas das eficiências térmicas esboçadas na Figura 31 mostram a possibilidade de algumas misturas DBE alcançarem eficiências térmicas superiores ao diesel comercial B7, ou ao menos apresentarem valores de eficiência de mesma ordem. Logo, os resultados sugerem a possibilidade de se aprimorar o desempenho do diesel comercial B7 com o auxílio de etanol.

Contudo, nota-se a tendência de redução da eficiência térmica em função do crescimento da concentração de etanol nas misturas. Por isso, pode-se presumir que, em decorrência dos efeitos do etanol no processo de combustão, a injeção de combustível fixada em 10,5 BTDC não é a condição mais adequada para todas as misturas avaliadas. Isto justifica o porquê de apenas algumas condições experimentais e misturas ternárias terem se mostrado capazes de superar as eficiências térmicas do diesel B7 e remete à possibilidade de crescimento das eficiências térmicas através da otimização dos instantes de injeção de combustível para cada mistura ternária individualmente.

Os resultados de eficiência térmica da Figura 31 confirmam que as conversões de energia no motor ocorrem em média $6 \%$ mais eficientemente nas operações a $50 \%$ do que a $25 \%$ dos torques máximos de $\mathrm{B} 7$, conforme já sinalizado pela Figura 30 . Este comportamento pode ser compreendido pelo favorecimento das inércias do conjunto com torques mais elevados, frente aos atritos envolvidos na operação do motor, bem como em razão das maiores pressões proporcionadas pelo turbo-compressor em situações de maior carga. O motor mais quente facilita a vaporização de combustível, também contribuindo para combustões mais eficientes nas operações a $50 \%$ dos torques máximos de B7. Já a suave queda de eficiência com o acréscimo da rotação sugere taxas de geração de calor menores do que perdas por transferência de calor. 


\subsection{3}

\section{Processo de Combustão com Avanços de Injeção Fixos}

O registro da pressão no interior de um dos cilindros do motor em função do ângulo de virabrequim permite a estimativa de alguns parâmetros fundamentais na elucidação do processo de combustão desencadeado na câmara, tais como: atraso da ignição, taxa de liberação de calor, calor liberado, variação da pressão, pressão máxima, dentre outros. Adicionalmente, as curvas de pressão indicada possibilitam observações qualitativas e nutrem a percepção prévia de tendências do comportamento de alguns resultados que serão apresentados mais adiante.

As curvas suavizadas de pressão indicada em função do ângulo de virabrequim seguem apresentadas abaixo pela Figura 32, Figura 33 e Figura 34 nas condições experimentais de $25 \%$ e $50 \%$ dos torques máximos de B7 com cada combustível e rotação proposta para os testes.
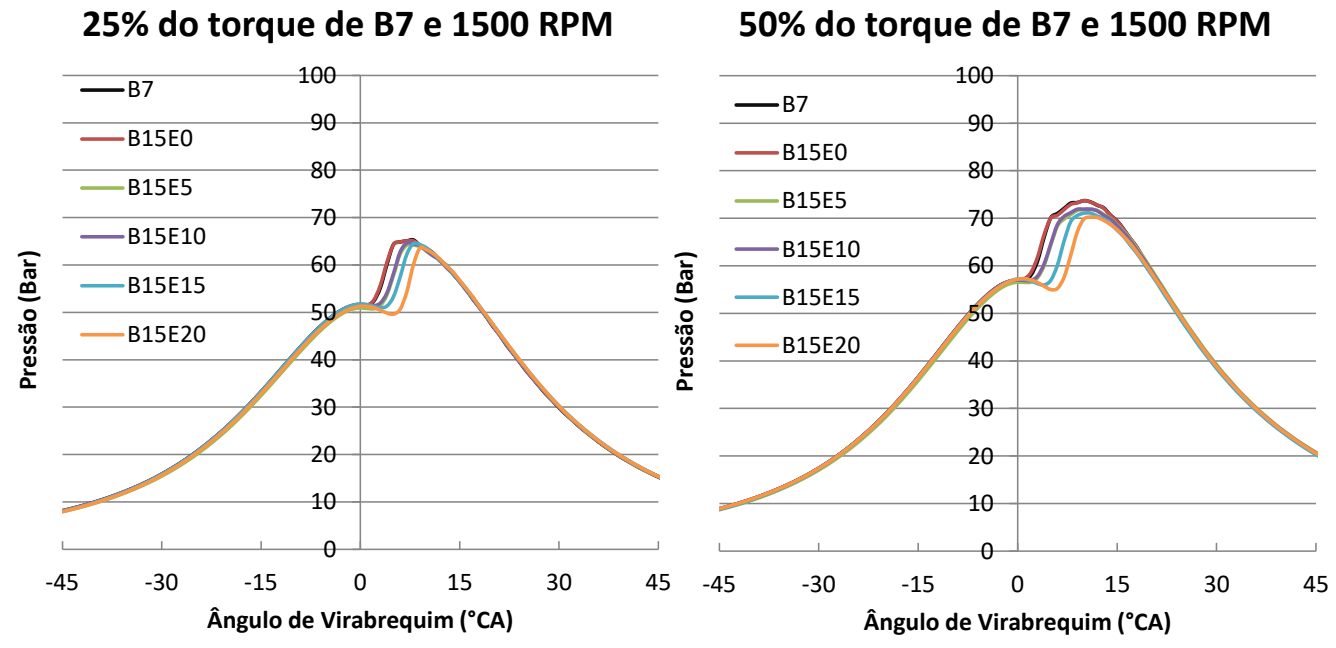

Figura 32 - Pressão indicada - 25\% e 50\% a 1500RPM 
$25 \%$ do torque de B7 e 1800 RPM

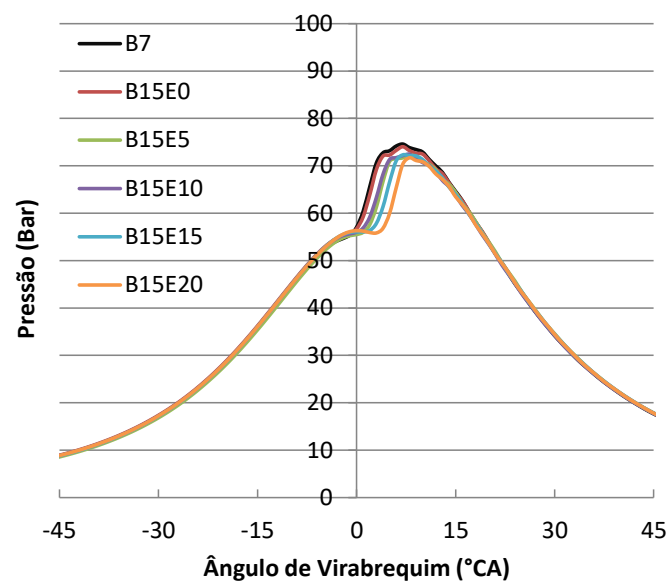

$50 \%$ do torque de B7 e 1800 RPM

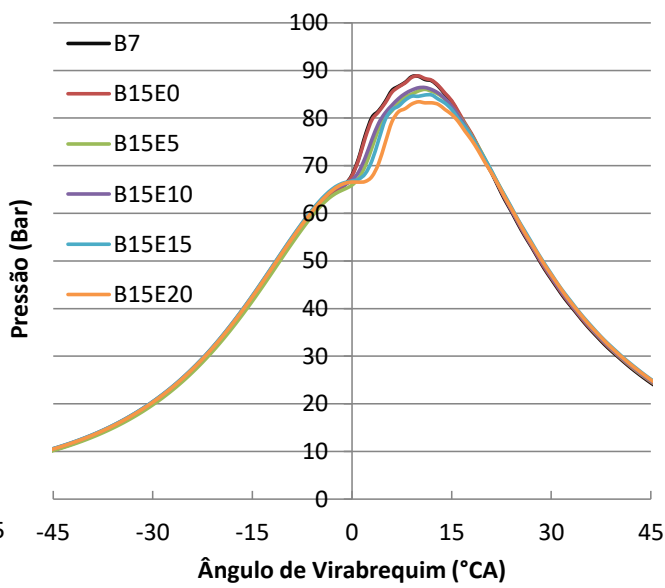

Figura 33 - Pressão indicada - 25\% e 50\% a 1800RPM

25\% do torque de B7 e 2100 RPM

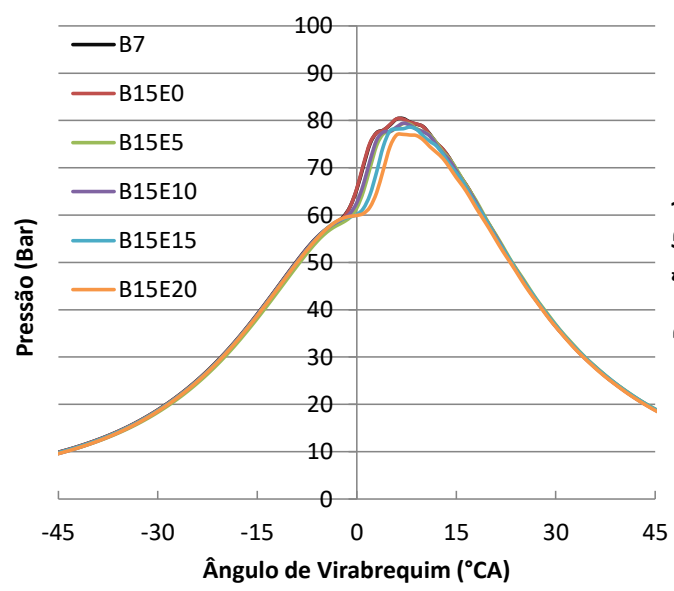

$50 \%$ do torque de B7 e 2100 RPM

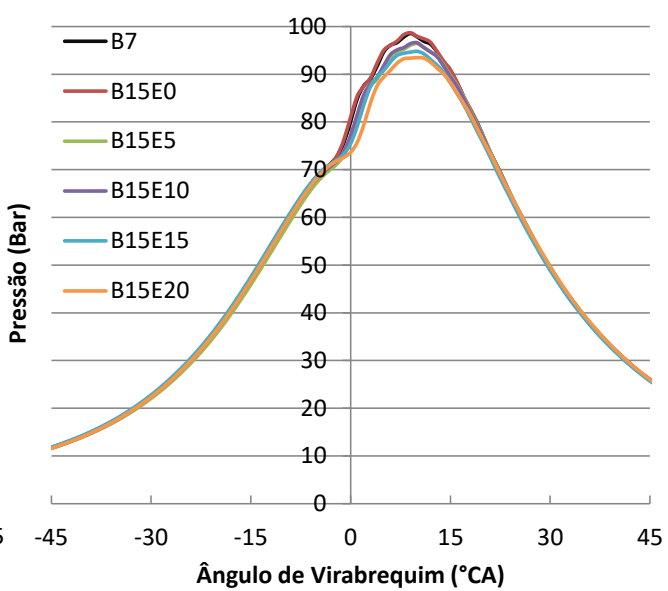

Figura 34 - Pressão indicada - 25\% e 50\% a 2100RPM

Os resultados de pressão indicada exibidos nas últimas três figuras (Figura 32, Figura 33 e Figura 34) revelam tendências muito similares associadas à participação de etanol nas misturas ternárias. Por isso, guardando-se as devidas individualidades quantitativas das diferentes condições experimentais avaliadas, é possível notar efeitos nítidos e recorrentes da presença de etanol nas misturas como, por exemplo, a redução das pressões máximas e o aumento dos atrasos de ignição. O distanciamento entre os picos da pressão de compressão e as pressões máximas da combustão com o aumento do etanol nas misturas é um indício contundente de maiores atrasos da ignição.

O monitoramento das pressões máximas durante os testes é importante não somente para assegurar a integridade do motor, mas também alertar para elevações nos níveis de emissões de $\mathrm{NO}_{\mathrm{X}}$, já que maiores pressões (e temperaturas) levam ao crescimento das emissões deste poluente [1]. A Figura 
35 exibe as pressões máximas registradas com a injeção em 10,5 BTDC.
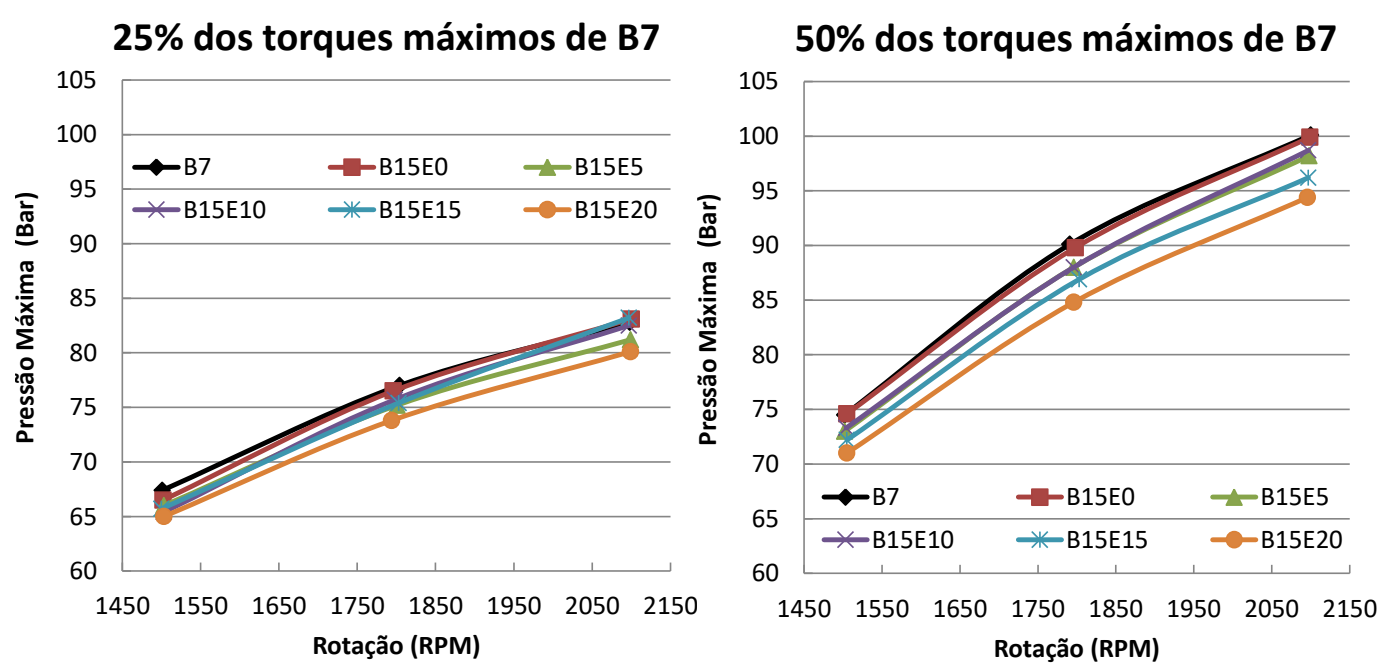

Figura 35 - Pressões máximas - avanço de 10,5 BTDC

Nas pressões máximas apresentadas pela Figura 35, é possível perceber o efeito do etanol na combustão das misturas, em que os picos de pressão são reduzidos em até $6 \%$ com a introdução de etanol nas misturas, em virtude das características físico-químicas deste álcool, tais como o elevado calor latente de vaporização e o reduzido número de cetano.

Assim como as curvas de pressão indicada, as curvas de liberação de calor também fornecem informações sobre o comportamento da combustão e influências do etanol nas misturas. No entanto, em razão dos diferentes poderes caloríficos das misturas avaliadas, é mais coerente apresentar as curvas através da razão entre a energia liberada pela combustão e a energia contida na massa de combustível injetada, conforme mostra a Figura 36, Figura 37 e Figura 38.

25\% do torque de B7 e 1500 RPM

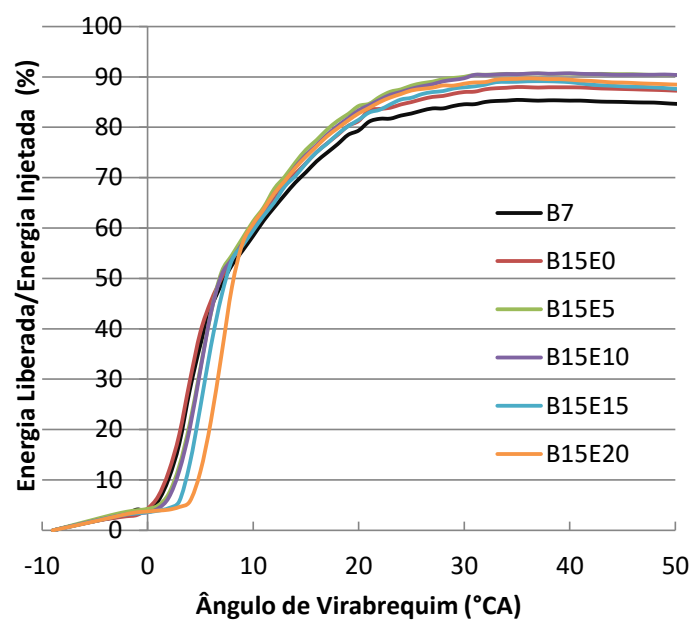

$50 \%$ do torque de B7 e 1500 RPM

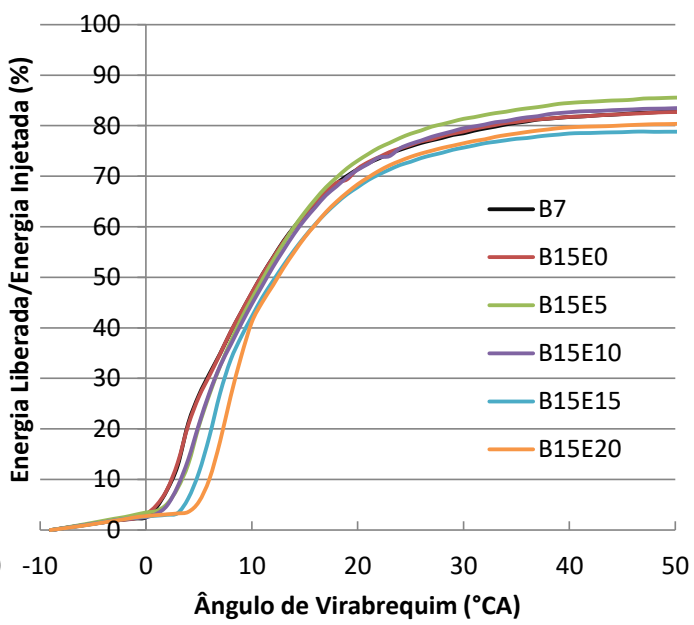

Figura 36 - Liberação de calor - 25\% e 50\% 1500RPM 
25\% do torque de B7 e 1800 RPM

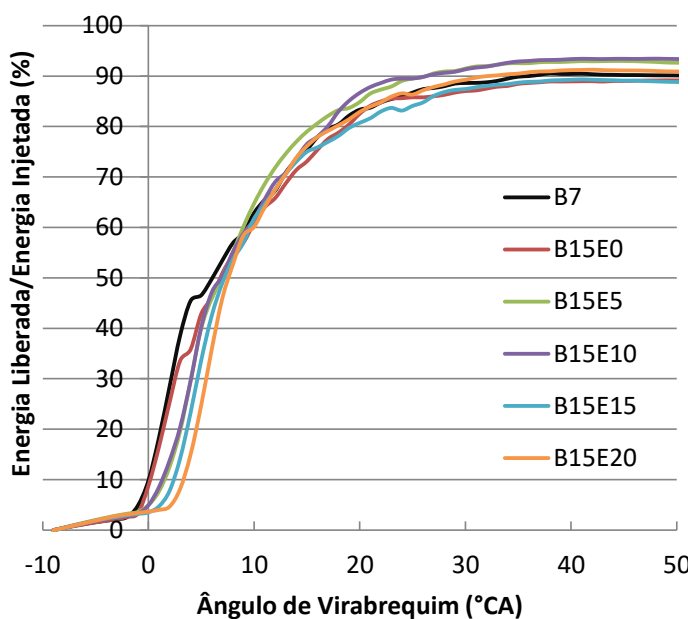

Figura 37 - Liberação de calor - 25\% e 50\% a 1800RPM

$50 \%$ do torque de B7 e 1800 RPM

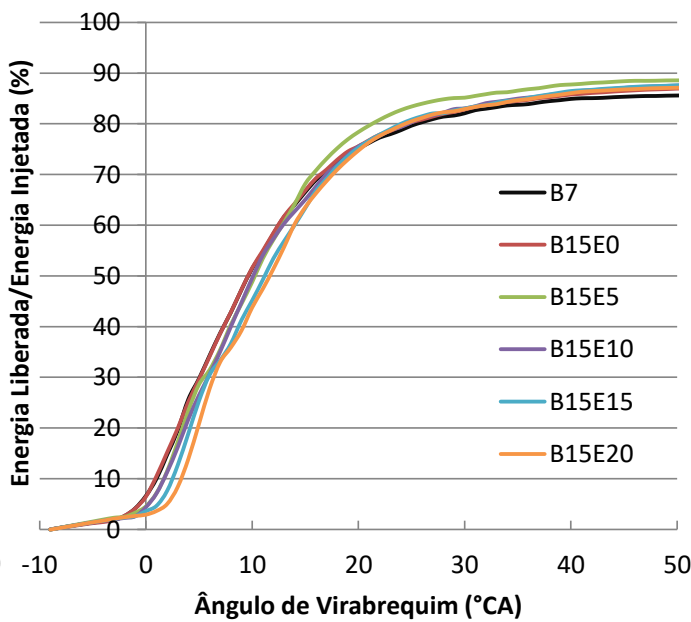

$50 \%$ do torque de B7 e 2100 RPM
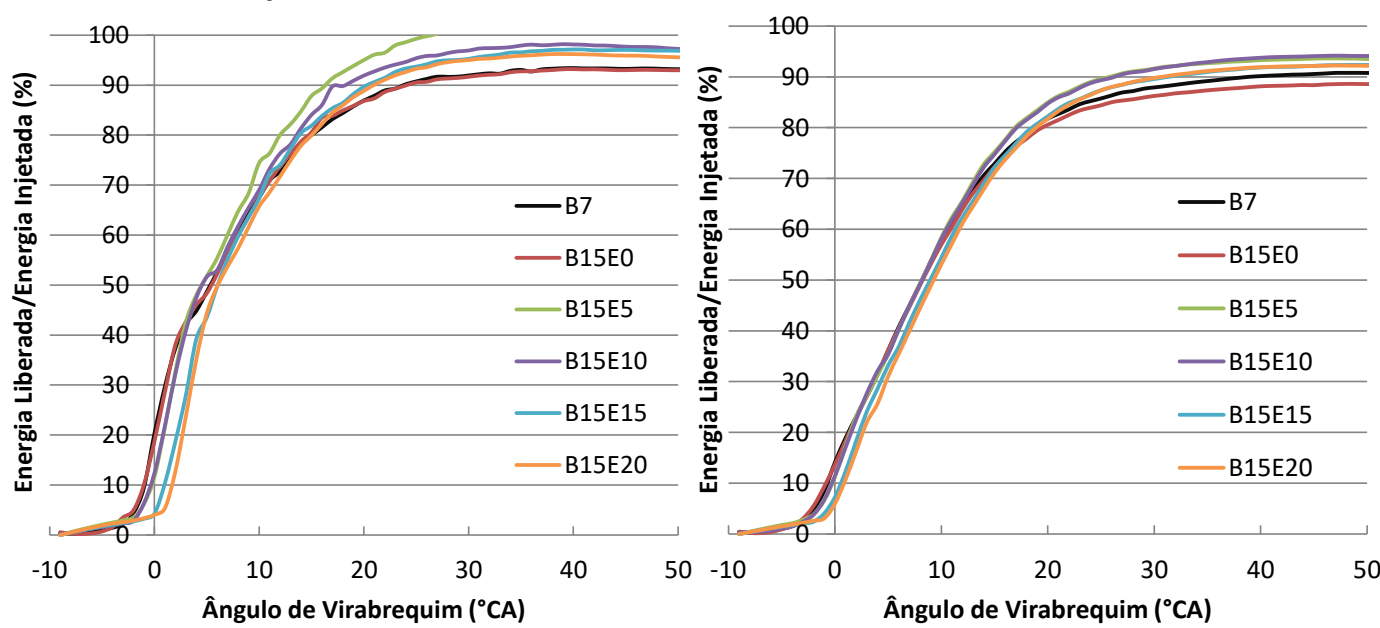

Figura 38 - Liberação de calor - 25\% e 50\% a 2100RPM

Assim, reforçando o que já foi observado nas curvas de pressão indicada, estas curvas mostram que em todas as condições de teste o início da combustão é postergado com a crescente participação de etanol nas misturas, ou seja, o atraso da ignição aumenta com maiores proporções de etanol nas misturas, tendo-se em vista o estabelecimento da injeção de combustível em 10,5 BTDC.

Além disto, outro comportamento evidenciado nas curvas de energia liberada é a tendência de maiores parcelas de energia injetada serem liberadas em forma de calor nos testes de rotações mais elevadas. Isto, possivelmente acontece devido às condições mais favoráveis para autoignição do combustível proporcionadas por: maiores pressões na admissão do motor, temperaturas de compressão mais elevadas e minimização da transferência de calor através das 
paredes do cilindro em situações operacionais com um mesmo torque e rotações crescentes.

Por outro lado, menores parcelas de energia injetada são liberadas em forma de calor quando as condições operacionais vão de $25 \%$ para $50 \%$ dos torques máximos de B7: em média $6,6 \%, 2,6 \%$ e 5,1\% inferiores para as rotações de 1500, 1800 e 2100 RPM, respectivamente. É razoável imaginar que tal fato ocorra em decorrência da necessidade da utilização de misturas mais ricas na câmara de combustão, isto é, a injeção de maiores quantidades de combustível que podem, consequentemente, tornar as combustões não tão completas quanto nas situações de cargas inferiores.

Na Figura 37, a curva de $25 \%$ do torque máximo de B7 a 2100 RPM com a mistura B15E5 indica valores de até $102 \%$, sugerindo uma liberação de calor inconsistente, tendo em vista a quantidade de energia disponibilizada pela massa de combustível injetada. Todavia, é de se suspeitar que resultados de liberação de calor superestimados estejam fortemente relacionados aos valores utilizados para poder calorífico inferior. A precisão deste parâmetro é fundamental para a quantificação da energia contida na massa de combustível injetada no cilindro. Entretanto, a indisponibilidade de um calorímetro para a estimativa do poder calorífico de cada mistura empregada nos testes fez este parâmetro ser estabelecido com auxílio da literatura, conforme apresentado no Anexo A.

A Tabela 8 traz os atrasos da ignição para as condições de $25 \%$ e $50 \%$ dos torques máximos de $B 7$. Vale relembrar que em ambos os casos a injeção de combustível está fixada em 10,5 BTDC.

Tabela 8 - Atraso da ignição - avanço de 10,5 BTDC

\begin{tabular}{|c|c|c|c|c|c|c|}
\hline $\begin{array}{c}\text { Rotação } \\
\text { (RPM) }\end{array}$ & B7 & B15E0 & B15E5 & B15E10 & B15E15 & B15E20 \\
\hline \multicolumn{7}{|c|}{$\mathbf{2 5 \%}$ dos torques máximos de B7 } \\
\hline 1500 & $14,0^{\circ}$ & $13,7^{\circ}$ & $14,3^{\circ}$ & $14,7^{\circ}$ & $16,0^{\circ}$ & $17,7^{\circ}$ \\
\hline 1800 & $11,0^{\circ}$ & $14,3^{\circ}$ & $14,0^{\circ}$ & $15,0^{\circ}$ & $14,0^{\circ}$ & $15,7^{\circ}$ \\
\hline 2100 & $9,0^{\circ}$ & $8,0^{\circ}$ & $9,7^{\circ}$ & $9,0^{\circ}$ & $12,0^{\circ}$ & $13,0^{\circ}$ \\
\hline 1500 & $14,0^{\circ}$ & $\mathbf{5 0} \%$ dos torques máximos de B7 \\
\hline 1800 & $10,7^{\circ}$ & $14,0^{\circ}$ & $12,7^{\circ}$ & $17,3^{\circ}$ & $17,3^{\circ}$ \\
\hline 2100 & $9,7^{\circ}$ & $14,3^{\circ}$ & $10,7^{\circ}$ & $14,3^{\circ}$ & $15,0^{\circ}$ \\
\hline
\end{tabular}

O atraso da ignição pode ser interpretado como um indicativo de quão favoráveis são as condições no interior do cilindro no instante de injeção do combustível e da adequação do processo de vaporização do combustível para o 
encorajamento da autoignição das misturas ternárias via ignição por compressão. Portanto, quando o atraso da ignição é menor, significa que o combustível é exposto a condições de maior favorecimento à autoignição, seja pela combinação de pressão e temperatura na câmara termodinamicamente mais propícia ou pelas características físico-químicas dos combustíveis. A redução do atraso de ignição nas rotações mais elevadas do motor, apresentada pela Tabela 8, é exemplo do favorecimento à autoignição na câmara através de condições de pressão e temperatura mais adequadas nessas situações. Enquanto os acréscimos no intervalo de atraso da ignição diante da presença de etanol são exemplos da interferência das propriedades deste álcool na autoignição das misturas.

Os valores apresentados na Tabela 8 deixam evidentes os prolongamentos destes intervalos em função do aumento da participação de etanol, conforme já observado por Park et al. [102] [111] e Hulwan et al. [96]. O atraso da ignição mostrou-se até $44 \%$ maior com as misturas B15E20 em comparação ao diesel comercial B7, fato que também justifica a menor eficiência térmica do motor neste caso, conforme já apresentado na Figura 31 e também nos resultados da tese de Pradelle [14]. Este crescimento do atraso da ignição ocorre em razão do calor latente do etanol, superior ao do óleo diesel, que faz uma maior quantidade de calor ser retirada da carga contida no interior do cilindro antes do processo de combustão para a evaporação da mistura, inibindo o crescimento da pressão e da temperatura, por conseguinte, retardando o início da combustão.

Os resultados dos atrasos de ignição não apenas corroboram com indícios visuais já levantados nas avaliações das curvas de pressão indicada e curvas de liberação de calor, mas também mostram a quantificação do intervalo de tempo compreendido entre o avanço estático da injeção de combustível e a estimativa do início da combustão, que é o intervalo correspondente ao atraso da ignição.

Por fim, apresentam-se na Tabela 9 as diferenças entre CA90 e CA10 que são parâmetros que indicam, respectivamente, os ângulos de virabrequim nos quais são atingidos $90 \%$ e $10 \%$ do calor total liberado durante o processo de combustão. Estes resultados estimam o intervalo compreendido entre o trecho inicial e final da combustão, permitindo percepções sobre a dimensão da duração da combustão para os diferentes combustíveis com o instante de injeção fixo em 10,5 BTDC (e condições de torque e rotação já predefinidas).

Os intervalos entre CA90 e CA10 da Tabela 9 exibem tendências de redução com o crescimento da presença de etanol nas misturas, fato bem evidenciado na comparação dos resultados do combustível B7 com a mistura 
B15E20. A abreviação do processo de combustão em misturas com maiores quantidades de etanol, já observado por Pradelle [14] e analisado por Hulwan et al. [96], relaciona-se com características de maior resistência à autoignição e maiores taxas de liberação de calor deste combustível.

Tabela 9 - Intervalo entre CA90 e CA10 - avanço de $10,5^{\circ}$ BTDC

\begin{tabular}{|c|c|c|c|c|c|c|}
\hline $\begin{array}{c}\text { Rotação } \\
\text { (RPM) }\end{array}$ & B7 & B15E0 & B15E5 & B15E10 & B15E15 & B15E20 \\
\hline \multicolumn{7}{|c|}{$\mathbf{2 5 \%}$ dos torques máximos de B7 } \\
\hline 1500 & $16,3^{\circ}$ & $16,7^{\circ}$ & $15,3^{\circ}$ & $16,0^{\circ}$ & $15,0^{\circ}$ & $14,0^{\circ}$ \\
\hline 1800 & $19,0^{\circ}$ & $18,7^{\circ}$ & $16,3^{\circ}$ & $17,0^{\circ}$ & $16,7^{\circ}$ & $15,7^{\circ}$ \\
\hline 2100 & $21,0^{\circ}$ & $21,7^{\circ}$ & $20,0^{\circ}$ & $17,0^{\circ}$ & $19,0^{\circ}$ & $17,0^{\circ}$ \\
\hline \multicolumn{7}{|c}{$\mathbf{5 0} \%$ dos torques máximos de B7 } \\
\hline 1500 & $20,0^{\circ}$ & $20,3^{\circ}$ & $19,3^{\circ}$ & $21,3^{\circ}$ & $18,0^{\circ}$ & $18,0^{\circ}$ \\
\hline 1800 & $22,3^{\circ}$ & $23,0^{\circ}$ & $20,3^{\circ}$ & $23,0^{\circ}$ & $20,7^{\circ}$ & $20,6^{\circ}$ \\
\hline 2100 & $22,0^{\circ}$ & $22,0^{\circ}$ & $20,0^{\circ}$ & $20,7^{\circ}$ & $21,3^{\circ}$ & $19,7^{\circ}$ \\
\hline
\end{tabular}

\section{2}

\section{Busca por Avanços de Injeção Otimizados}

No item anterior (5.1) ficou notório que o desempenho e o comportamento das combustões para as diferentes misturas com um mesmo instante de injeção de combustível experimentam impactos associados à presença de etanol. Por isso, a investigação dos melhores instantes para a injeção das misturas ternárias é realizada com a finalidade de verificar o ponto de injeção no qual o desempenho do motor é maximizado.

Conforme a metodologia proposta no item 3.5, as misturas B15E5, B15E10, B15E15 e B15E20 são expostas a avaliações com outros três avanços de injeção de combustível - além do avanço original dos testes de 10,5 BTDC na busca das melhores respostas com as condições experimentais referenciadas pelos torques máximos de diesel comercial B7 da Tabela 4.

O consumo específico de combustível, apesar de não ponderar diferenças entre valores de poder calorífico, é um parâmetro diretamente relacionado à eficiência de um motor, segundo já mencionado anteriormente. As tabelas do Anexo $E$ apresentam os resultados completos das investigações sobre os instantes de injeção otimizados para as misturas. Já a Figura 39, Figura 40, Figura 41 e Figura 42 mostram o consumo específico de combustível (cec) nos diferentes instantes de injeção para cada mistura ternária nas condições de $25 \%$ e $50 \%$ dos torques máximos de B7: 
B15E5

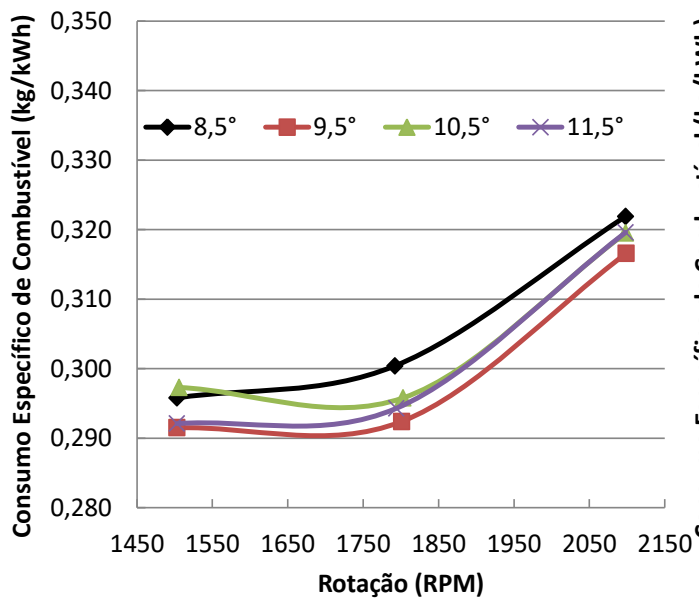

B15E5

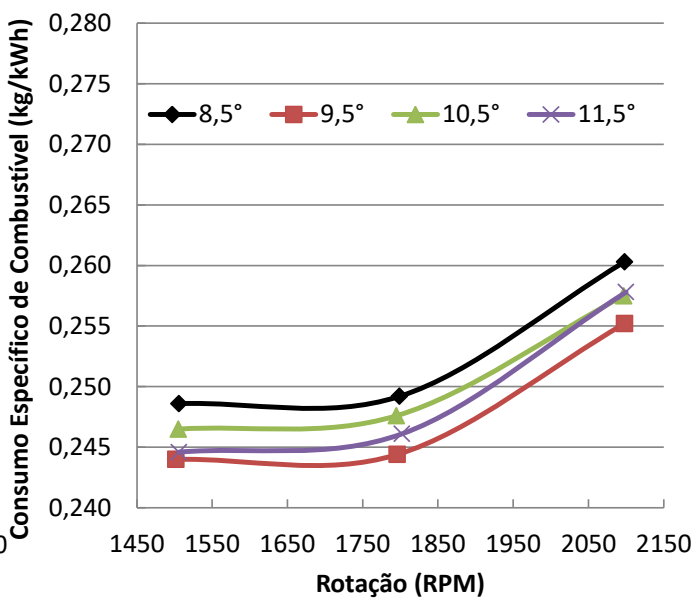

Figura 39 - B15E5 cec a 25\% e 50\% dos torques máximos de B7
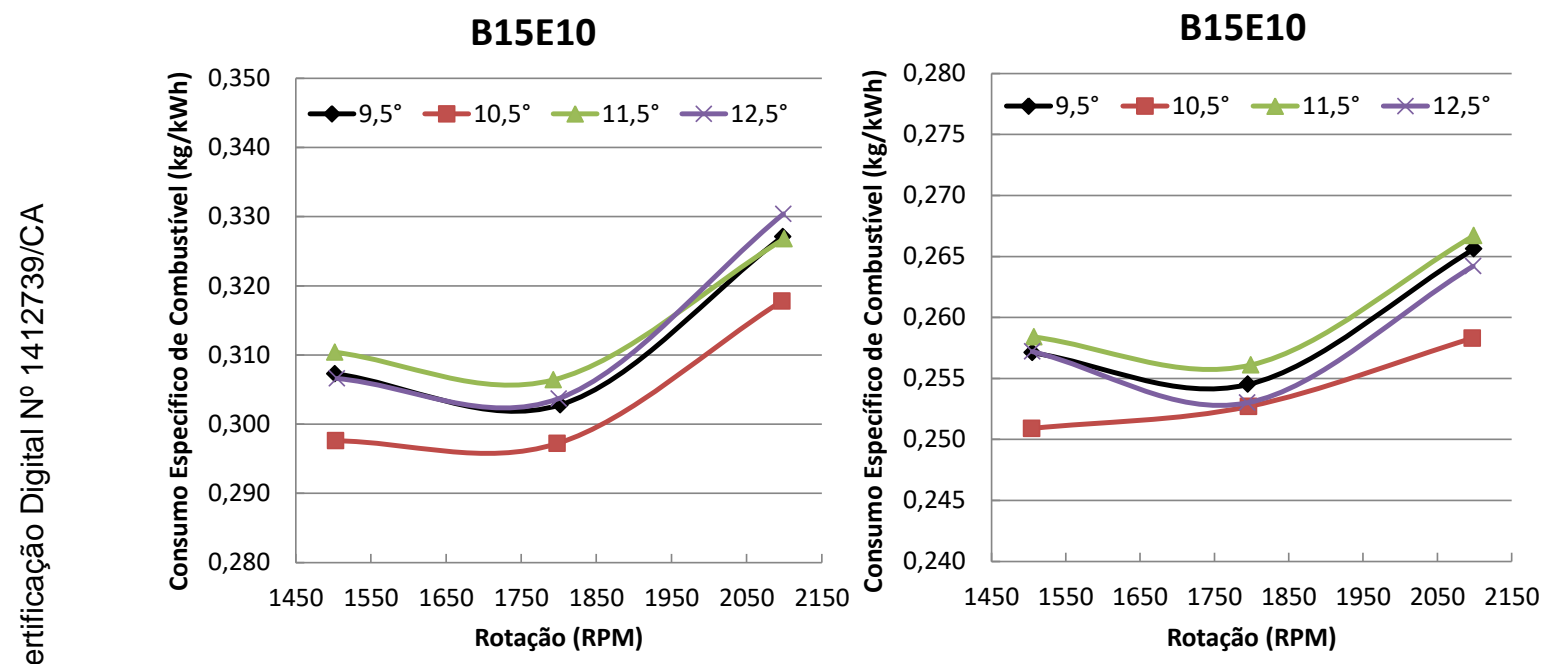

Figura 40 - B15E10 cec a 25\% e 50\% dos torques máximos de B7

B15E15

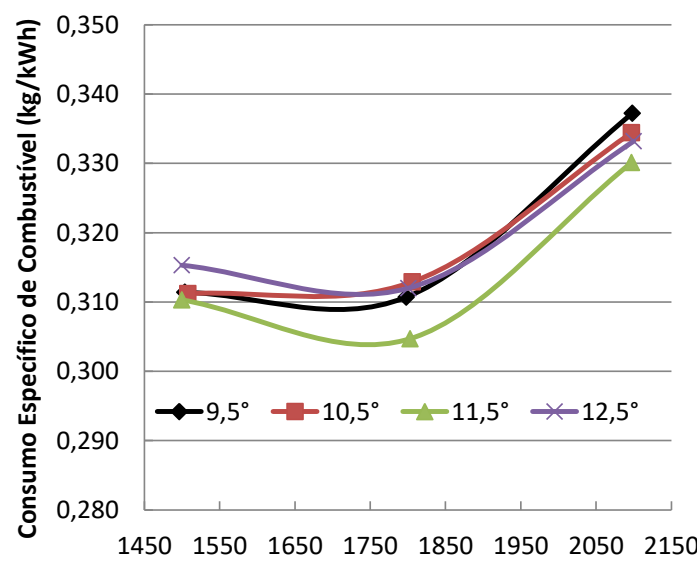

Rotação (RPM)

\section{B15E15}

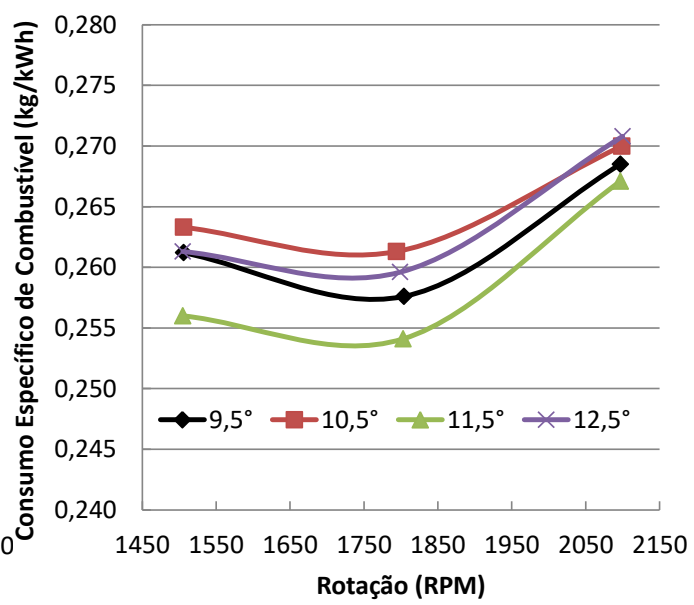

Figura 41 - B15E15 cec a 25\% e 50\% dos torques máximos de B7 
B15E20

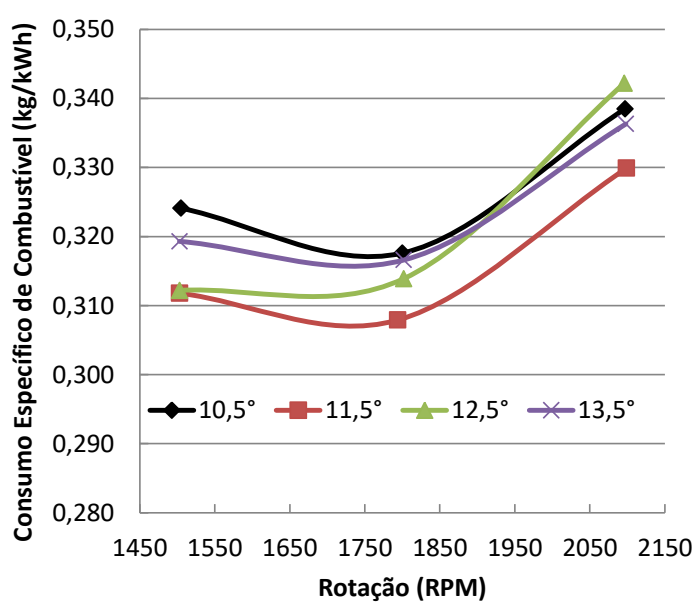

B15E20

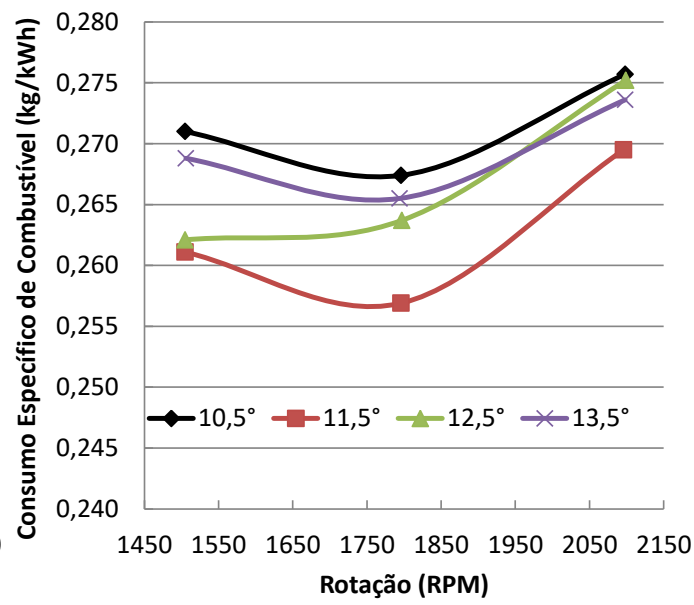

Figura 42 - B15E20 cec a 25\% e 50\% dos torques máximos de B7

De acordo com o conceito já apresentado previamente nesta dissertação, o consumo específico de combustível é uma estimativa da massa necessária de combustível para a obtenção de uma única unidade de energia de trabalho executado pelo motor. Então, os instantes de injeção de combustível que apresentam os menores valores para consumo específico de combustível, devem ser eleitos avanços ótimos de injeção, conforme resume a Tabela 10.

Tabela 10 - Resumo da seleção dos avanços ótimos

\begin{tabular}{|c|c|c|c|c|}
\hline Combustível & B15E5 & B15E10 & B15E15 & B15E20 \\
\hline Avanço Ótimo ( ${ }^{\circ}$ BTDC) & 9,5 & 10,5 & 11,5 & 11,5 \\
\hline
\end{tabular}

Assim, a busca pela otimização dos avanços na injeção de combustível aponta uma tendência de que cada $5 \%$ de acréscimo de etanol na mistura ternária corresponderia à antecipação de um grau no avanço da injeção, conforme exibido pela Tabela 10 para as misturas B15E5, B15E10 e B15E15. A única exceção à regra deu-se pela mistura com $20 \%$ de teor de etanol (B15E20), que estabilizou sua otimização de avanço com a mesma antecipação requerida pela mistura B15E15.

\section{3}

\section{Avaliações com Avanços de Injeção Otimizados}

Por fim, a análise dos testes com instantes otimizados de injeção combustível constitui a etapa final deste capítulo. O intuito das avaliações deste último item da dissertação não se restringe à abordagem da relevância da determinação dos instantes ótimos de injeção de combustível no desencadeamento do processo de combustão, mas também trazer à tona 
vantagens da substituição parcial do óleo diesel por biocombustíveis em motores de ignição por compressão pelo abastecimento através de misturas ternárias de diesel, biodiesel e etanol.

Assim como aconteceu no item 5.1, as avaliações deste item somente consideram as condições de $25 \%$ e $50 \%$ dos torques máximos de B7 para as três rotações definidas pela Tabela 4 . O estudo realizado a seguir não chega a envolver resultados das condições de $100 \%$ de torque com cada mistura testada, pois estas não representam condições operacionais semelhantes, inviabilizando análises comparativas. De qualquer forma, os resultados que compõem a investigação proposta neste item, bem como alguns resultados complementares, encontram-se integralmente relacionados no Anexo F.

Após as avaliações de desempenho de testes com instante de injeção de combustível fixo em 10,5 $5^{\circ}$ BTDC, que evidenciaram efeitos do etanol no funcionamento do motor e motivaram a busca por instantes ótimos para a injeção de misturas que contenham este álcool, agora se analisa a performance do motor com avanços otimizados nas condições de $25 \%$ e $50 \%$ dos torques máximos de $B 7$ e rotações da Tabela 7.

\subsection{1}

\section{Desempenho com Avanços Otimizados}

Em posse dos resultados fornecidos para os testes com melhores avanços de injeção (eleitos no item 5.2) para os combustíveis de diferentes poderes caloríficos, é possível apresentar as eficiências térmicas na Figura 43.
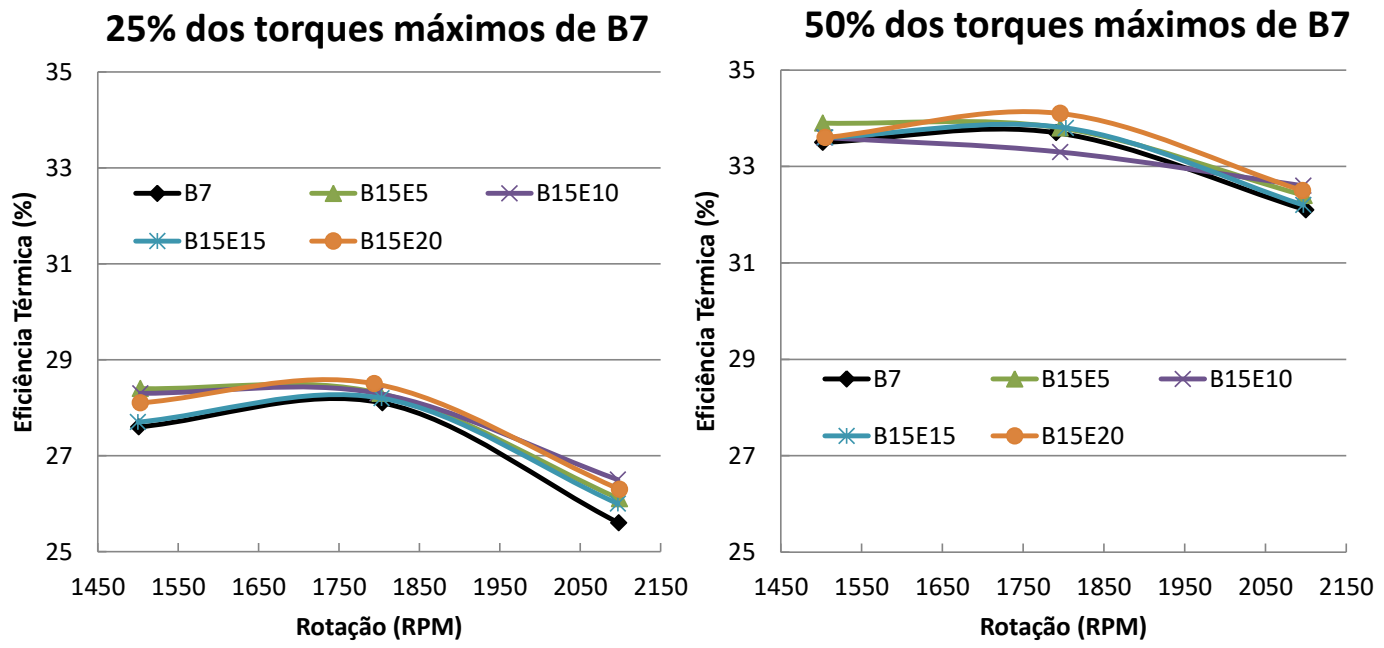

Figura 43 - Eficiência térmica - avanços otimizados 
$\mathrm{Na}$ análise da eficiência térmica com avanços fixados em 10,5 BTDC, já apresentada no item 5.1.2 e considerando-se a Figura 31, sugeriu-se que desempenhos superiores ao do diesel comercial B7 para certas condições operacionais de algumas misturas ternárias indicariam que melhorias nas eficiências térmicas seriam possíveis mediante ajustes nos instantes de injeção das misturas ternárias.

A Figura 43 confirma, então, possíveis ganhos nas eficiências térmicas com misturas ternárias através de instantes de injeção mais adequados para estes combustíveis, já que estabelece uma faixa de resultados acima daquela estabelecida na Figura 31 para misturas DBE com instante de injeção de combustível fixo em 10,5 BTDC. Os resultados da Figura 43 tornam-se ainda mais expressivos por conseguirem explicitar o potencial das misturas ternárias, expostas à presença de etanol, em superar a eficiência térmica do diesel comercial B7 em motores de ignição por compressão.

Os resultados promissores da Figura 43 suscitam também o interesse de que sejam conhecidas e ponderadas as contribuições relativas à presença de etanol no crescimento dos valores para as eficiências térmicas. Para isso, a eq. (15) do item 4.6, elaborada no presente trabalho, estima a parcela da eficiência térmica correspondente à presença de etanol na mistura em questão, definida como a eficiência térmica do etanol em mistura ternária ( $\left.\eta_{\mathrm{tE}-\mathrm{DBE}}\right)$.

Os resultados da Figura 44 trazem as eficiências térmicas do etanol presente nas misturas ternárias para as condições de $25 \%$ e $50 \%$ dos torques máximos de B7 em motor de ignição por compressão e com os avanços de injeção otimizados.

25\% dos torques máximos de B7

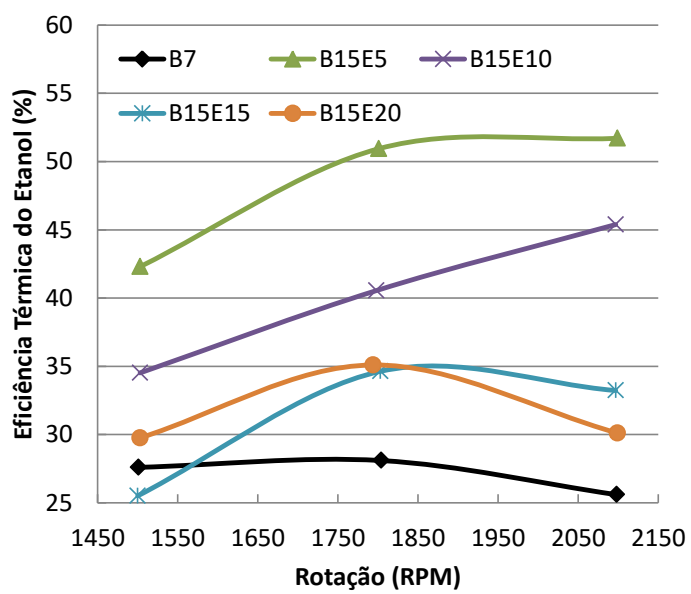

$50 \%$ dos torques máximos de B7

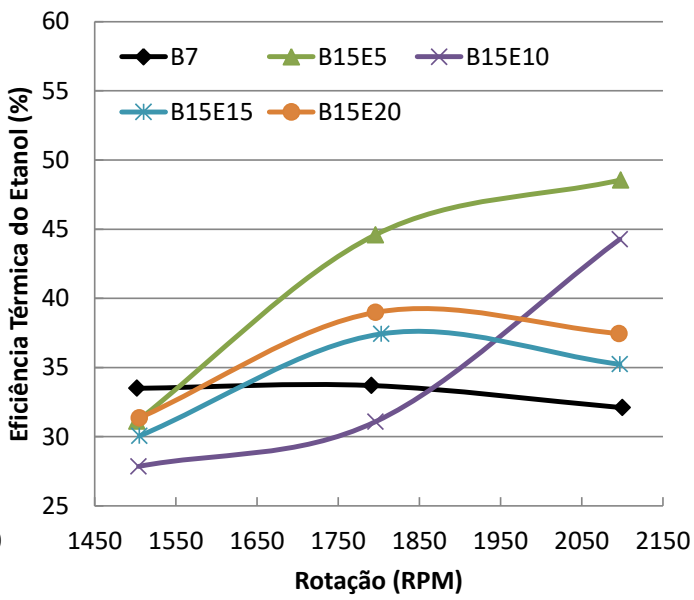

Figura 44 - Eficiência térmica do etanol - avanços otimizados 
A maior parte dos resultados exibidos na Figura 44 mostra-se superior às eficiências térmicas do diesel comercial B7 para as respectivas condições operacionais correlatas. Com isso, as eficiências térmicas das parcelas do etanol nas misturas ternárias revelam a capacidade deste álcool em favorecer o desempenho das conversões energéticas sem a alteração de qualquer parâmetro geométrico do motor.

Porém, para respaldar resultados que à primeira vista pareçam excessivamente otimistas (como, por exemplo, valores próximos dos $50 \%$ para a mistura B15E5 em algumas condições operacionais), é pertinente que as estimativas de incertezas para as eficiências térmicas de etanol nas misturas sejam quantificadas, de acordo com a eq. (C.4) da seção de Apêndices do presente trabalho, e explicitadas, conforme exibe a Tabela 11.

Tabela 11 - Incertezas absolutas das eficiências térmicas do etanol

\begin{tabular}{|c|c|c|c|c|}
\hline $\begin{array}{c}\text { Rotação } \\
\text { (RPM) }\end{array}$ & B15E5 & B15E10 & B15E15 & B15E20 \\
\hline \multicolumn{5}{|c|}{ 25\% dos torques máximos de B7 } \\
\hline 1500 & $13,6 \%$ & $6,4 \%$ & $4,0 \%$ & $2,9 \%$ \\
\hline 1800 & $4,7 \%$ & $2,2 \%$ & $1,4 \%$ & $1,0 \%$ \\
\hline 2100 & $1,7 \%$ & $0,8 \%$ & $0,5 \%$ & $0,4 \%$ \\
\hline \multicolumn{5}{|c|}{$50 \%$ dos torques máximos de B7 } \\
\hline 1500 & $5,5 \%$ & $2,6 \%$ & $1,6 \%$ & $1,2 \%$ \\
\hline 1800 & $2,0 \%$ & $0,9 \%$ & $0,6 \%$ & $0,4 \%$ \\
\hline 2100 & $7,5 \%$ & $3,5 \%$ & $2,2 \%$ & $1,6 \%$ \\
\hline
\end{tabular}

Com o intuito de melhor contextualizar os valores das incertezas da Tabela 11 , pode-se dizer que há contribuições significativas associadas ao coeficiente de sensibilidade da eficiência térmica de B15E0, presente no cálculo da eficiência térmica do etanol em misturas ternárias, e que por isso variações nos desvios padrão deste parâmetro influenciam diretamente as incertezas. A proporção de etanol nas misturas também é um aspecto importante a ser lembrado, pois faz que as flutuações de valores coletados e desvios padrão de parâmetros que compõem o cálculo da eficiência térmica do etanol em misturas tornem-se mais expressivos nas misturas com pequenas proporções do etanol (B15E5) frente a misturas com participação mais significativas deste álcool (B15E20). Por último, existem aspectos que nem sequer são quantificáveis nas estimativas de incerteza, mas que também não devem ser menosprezados, como é o caso da inviabilidade na reprodução de condições ambiente idênticas de realização dos testes. Inclusive, cabe salientar que, na sala de execução dos 
ensaios as variações de temperatura chegaram a $7^{\circ} \mathrm{C}$, enquanto a umidade relativa se modificou em até $14 \%$ na escala percentual desta variável.

De toda forma, as incertezas relacionadas na Tabela 11 garantem a consistência dos resultados da Figura 44 e asseguram que grande parte destes esteja em faixas de valores superiores à eficiência térmica do diesel comercial B7, em acordo com a análise já realizada previamente.

O consumo específico energético do etanol contido em uma mistura ternária representa outra abordagem na avaliação da conversão de energia de um combustível através da combustão. Este parâmetro indica a quantidade de energia química (MJ) que deve ser introduzida na câmara, pela injeção de determinada massa de combustível, para que seja entregue uma única unidade de energia mecânica em forma de trabalho do motor (kWh). Logo, assim como ocorre com valores de consumo específico de combustível, quanto menores são os resultados de consumo específico energético (ou conversão energética) da Figura 45, melhores desempenhos eles representam.
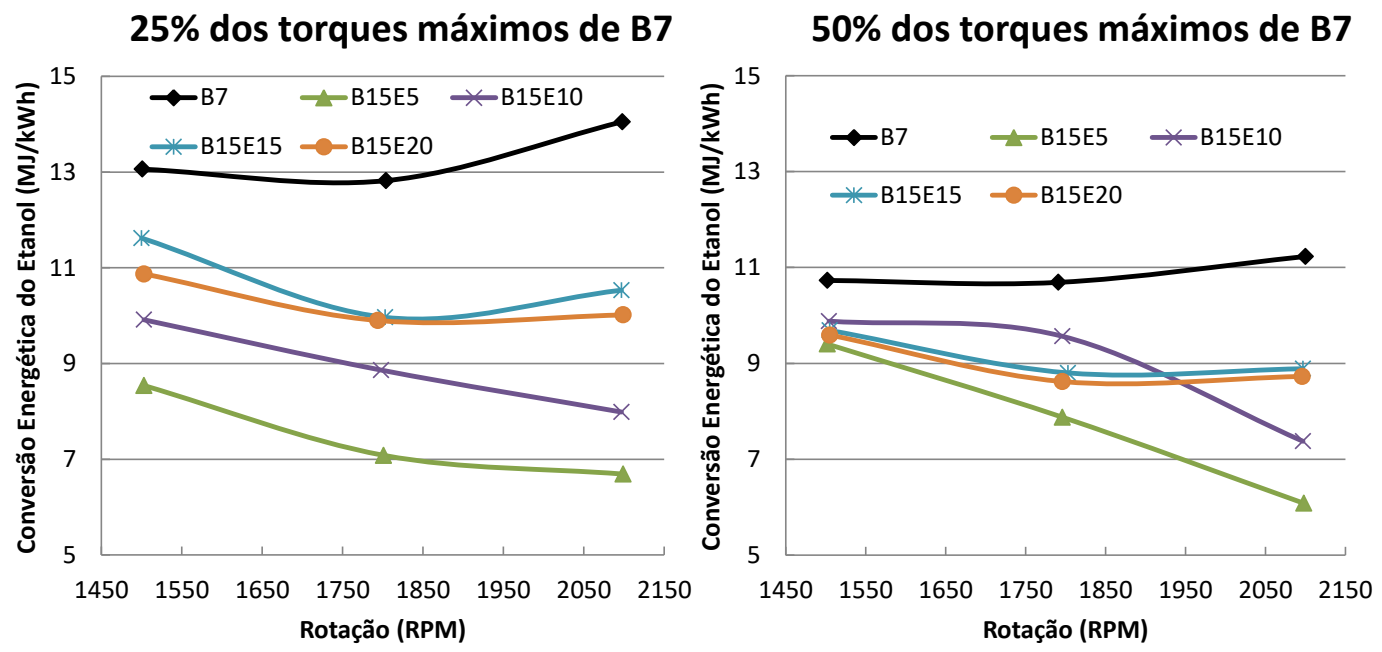

Figura 45 - Conversão energética do etanol - avanços otimizados

Porém, o consumo específico energético evidentemente é um resultado em termos energéticos $(\mathrm{MJ} / \mathrm{kWh})$, o que o diferencia do consumo específico de combustível pela presença do termo de poder calorífico inferior do combustível em sua formulação. Em outras palavras, isso significa, portanto, que resultados de consumo específico energético e de eficiência térmica devem fornecer conclusões semelhantes sobre desempenho de um motor, mesmo que diferentes combustíveis ou componentes de misturas sejam avaliadas.

Todavia, mesmo com a apresentação das eficiências térmicas do etanol pela Figura 44, é possível afirmar que a exibição dos resultados da Figura 45 
não representa uma redundância nas análises de desempenho. Pelo contrário, os valores de conversão energética do etanol nas misturas são de suma importância para comparar o desempenho das porções de etanol nas misturas ternárias via ignição por compressão com os resultados da dissertação de Villela [121] em seus testes com etanol via ignição por centelha.

$\mathrm{Na}$ dissertação de Villela [121] foram realizados testes em um motor Fiat $1.48 v$ Fire Tetrafuel, o qual opera via ignição por centelha com uma razão de compressão de 10,35:1. O motor foi testado em um dinamômetro de bancada e apresenta valores para torque máximo em torno de 121,5 Nm (a $2250 \mathrm{RPM}$ ), enquanto a potência máxima é de cerca de 60 kW (a 5500 RPM). A metodologia adotada por Villela baseou-se em três condições de operação fundamentais:

- Torque máximo: plena carga, ou seja, com 100\% de abertura da borboleta do acelerador a 2250 RPM;

- Potência máxima: plena carga, ou seja, com 100\% de abertura da borboleta do acelerador a 5500 RPM;

- Cruzeiro: $8^{\circ}$ de abertura da borboleta do acelerador a 1900 RPM.

Então, para cada uma das três condições operacionais citadas acima foram estabelecidas outras três condições, em função do combustível utilizado e da configuração do sistema de injeção:

- Etanol hidratado + sistema de injeção ajustado para etanol hidratado;

- Etanol anidro + sistema de injeção ajustado para etanol hidratado;

- Etanol anidro + sistema de injeção ajustado para etanol anidro.

Por fim, a Tabela 12 mostra os valores de consumo específico energético (conversão energética) do etanol em cada uma das condições de testes estabelecidas por Villela e segundo os resultados de sua dissertação [121].

Tabela 12 - Conversão energética de etanol - Resultados de Villela

\begin{tabular}{|c|c|c|c|}
\hline Teste & $\begin{array}{c}\text { Etanol } \\
\text { Hidratado }\end{array}$ & $\begin{array}{c}\text { Etanol } \\
\text { Anidro (Mapa Hidratado) }\end{array}$ & $\begin{array}{c}\text { Etanol } \\
\text { Anidro }\end{array}$ \\
\hline Potência Máxima & $12,8 \mathrm{MJ} / \mathrm{kWh}$ & $12,5 \mathrm{MJ} / \mathrm{kWh}$ & $12,5 \mathrm{MJ} / \mathrm{kWh}$ \\
\hline Torque Máximo & $10,9 \mathrm{MJ} / \mathrm{kWh}$ & $10,7 \mathrm{MJ} / \mathrm{kWh}$ & $10,8 \mathrm{MJ} / \mathrm{kWh}$ \\
\hline Condição de Cruzeiro & $13,5 \mathrm{MJ} / \mathrm{kWh}$ & $13,5 \mathrm{MJ} / \mathrm{kWh}$ & $13,5 \mathrm{MJ} / \mathrm{kWh}$ \\
\hline
\end{tabular}

Certamente o motor avaliado nesta dissertação não apresenta qualquer semelhança com aquele avaliado no trabalho de Villela, nem as condições operacionais dos testes realizados na presente dissertação se aproximam das definidas por Villela, mesmo assim a comparação entre os resultados serve para apontar valores típicos de consumo específico energético para o etanol em motores de ignição por compressão e ignição por centelha. 
Portanto, através da observação dos números da Tabela 12 e dos resultados indicados na Figura 45, fica nítido que o etanol desenvolve melhores conversões energéticas quando sua ignição ocorre por compressão do que por centelha. Os valores apresentados para a conversão energética de etanol no trabalho de Villela através da ignição por centelha ficam entre 10,7 e 13,5 $\mathrm{MJ} / \mathrm{kWh}$, enquanto a Figura 45 exibe valores entre 6,1 e 11,6 MJ/kWh, indicando a necessidade de menores energias químicas, injetadas através de massas de combustível para o fornecimento de trabalho em forma de energia mecânica.

A clara tendência de melhores desempenhos para a combustão do etanol quando a ignição é dada pela compressão, justifica-se pelo favorecimento do processo através da utilização de maiores razões de compressão. Vale lembrar que o motor testado nesta dissertação apresenta um razão de compressão de 15,8:1, enquanto a razão de compressão daquele testado por Villela de 10,35:1.

\section{3 .2}

\section{Processo de Combustão com Avanços Otimizados}

As curvas de pressão indicada, bem como de liberação de calor trazem consigo informações sobre o comportamento dos processos de combustão, conforme apresentado anteriormente pelo item 5.1.3. Contudo, o enfoque na análise das curvas neste item é destacar efeitos das modificações dos instantes de injeção de combustível para os avanços ótimos de cada mistura ternária.

As curvas suavizadas da pressão indicada são apresentadas na Figura 46, Figura 47 e Figura 48, enquanto as curvas de calor liberado estão representadas na Figura 49, Figura 50 e Figura 51. Tanto as curvas de pressão indicada quanto de calor liberado configuram testes nas condições experimentais de $25 \%$ e $50 \%$ dos torques máximos de B7 e conforme as rotações propostas na metodologia desta dissertação. Todavia, mais uma vez, em virtude dos variados valores de poder calorífico para os combustíveis testados, é mais equilibrado apresentar curvas de liberação de calor através da razão entre a energia liberada pela combustão e a energia contida na massa de combustível injetada. 
25\% do torque de B7 e 1500 RPM

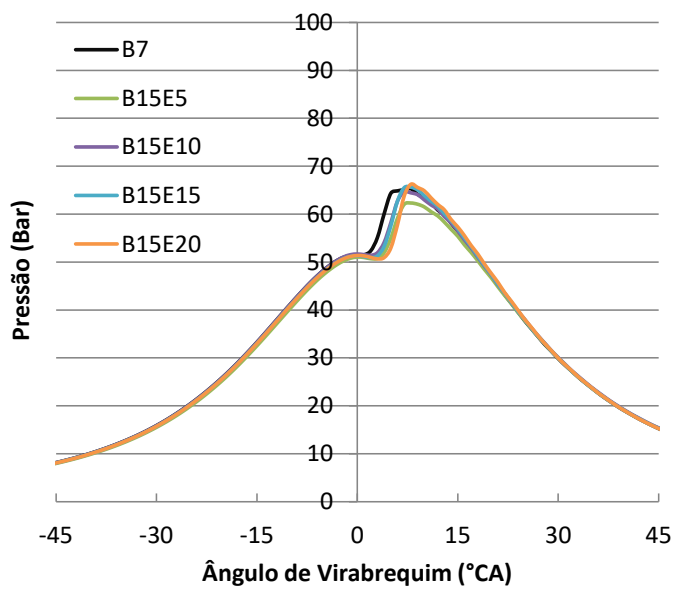

50\% do torque de B7 e 1500 RPM

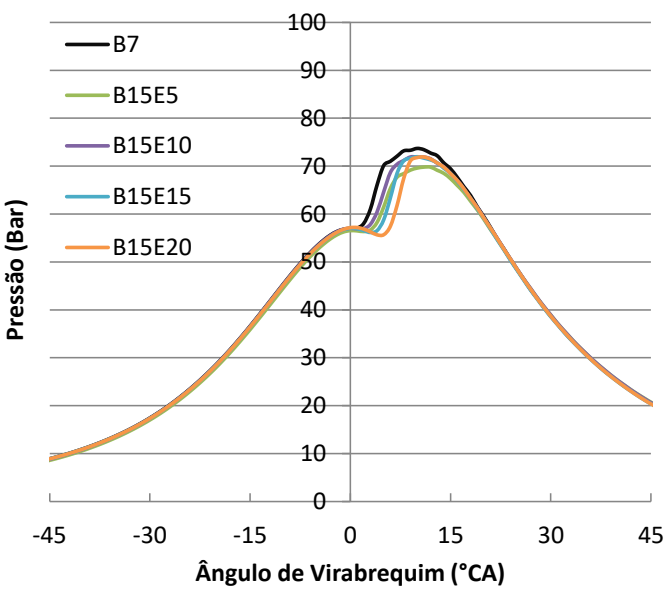

Figura 46 - Pressão - 25\% e 50\% a 1500RPM - Otimização

25\% do torque de B7 e 1800 RPM

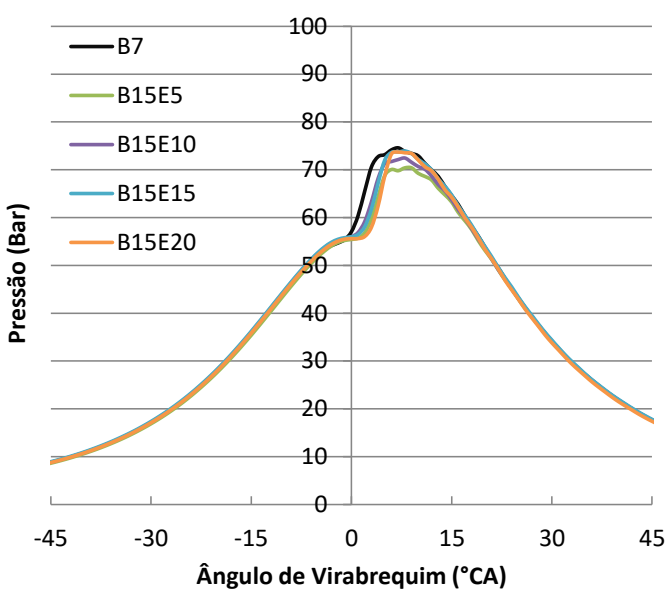

$50 \%$ do torque de B7 e 1800 RPM

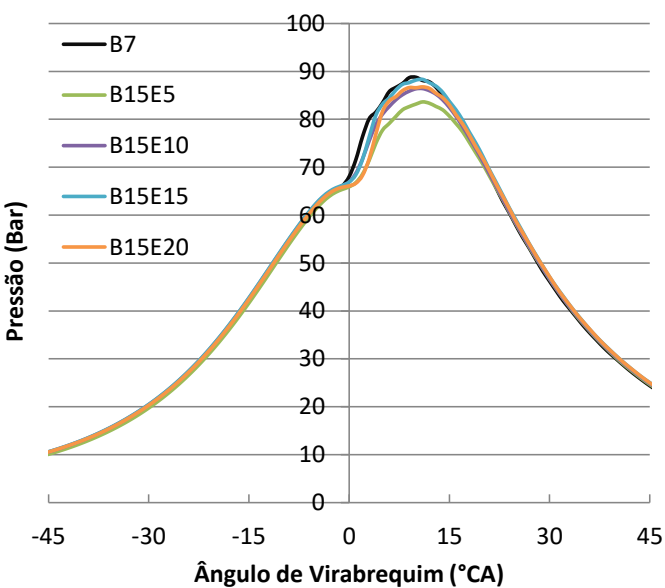

Figura 47 - Pressão - 25\% e 50\% a 1800RPM - Otimização

$25 \%$ do torque de B7 e 2100 RPM

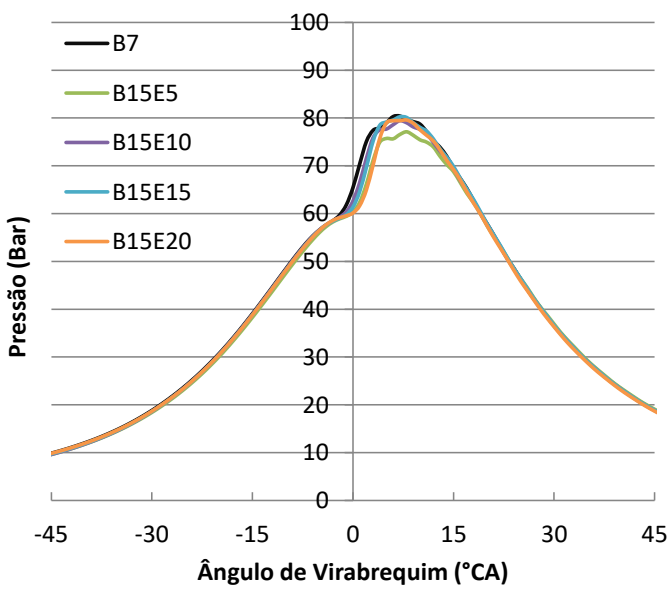

$50 \%$ do torque de B7 e 2100 RPM

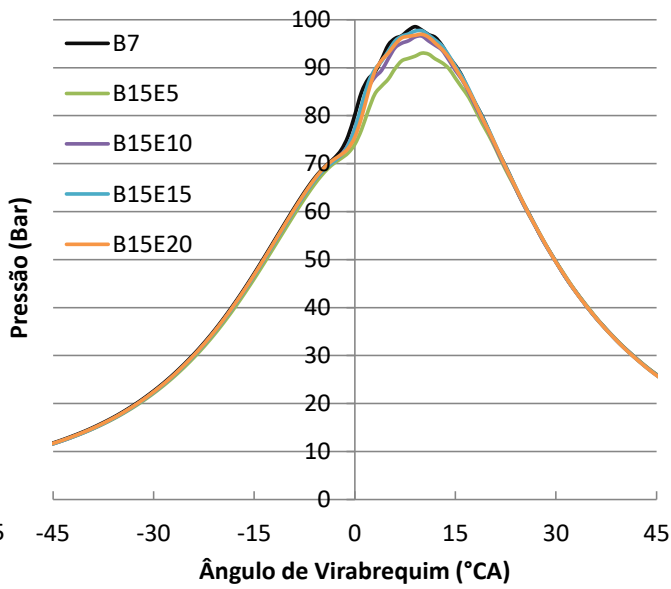

Figura 48 - Pressão - 25\% e 50\% a 2100RPM - Otimização 
25\% do torque de B7 e 1500 RPM

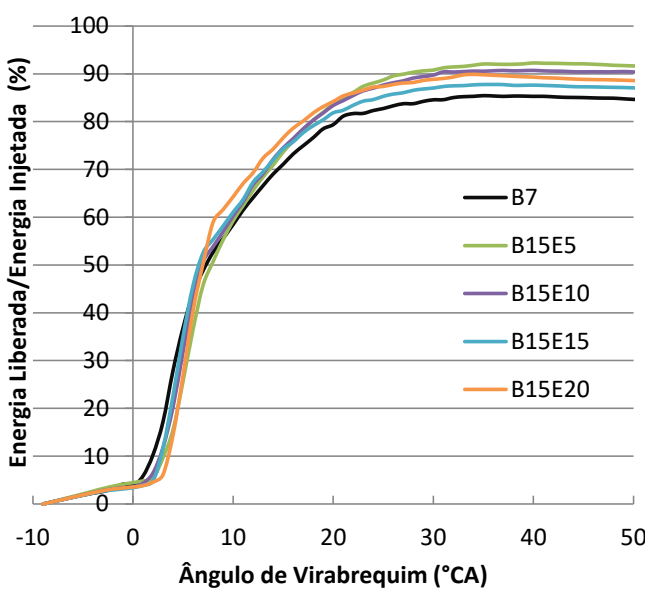

$50 \%$ do torque de B7 e 1500 RPM

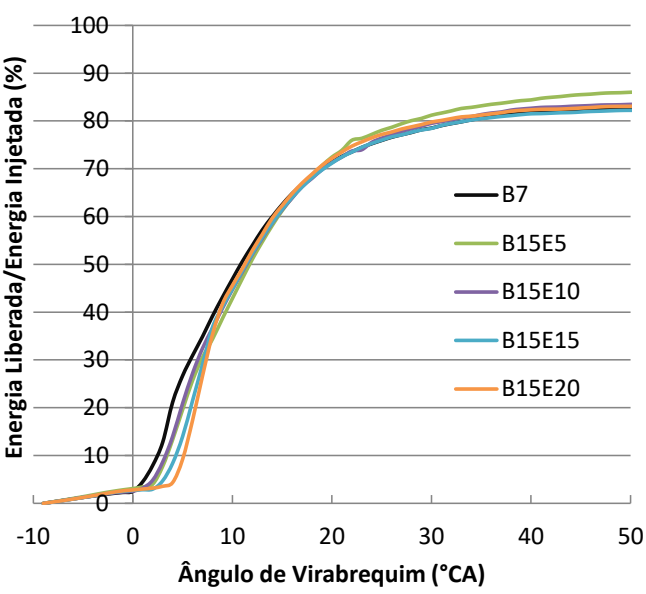

Figura 49 - Calor - 25\% e 50\% a 1500RPM - Otimização

25\% do torque de B7 e 1800 RPM

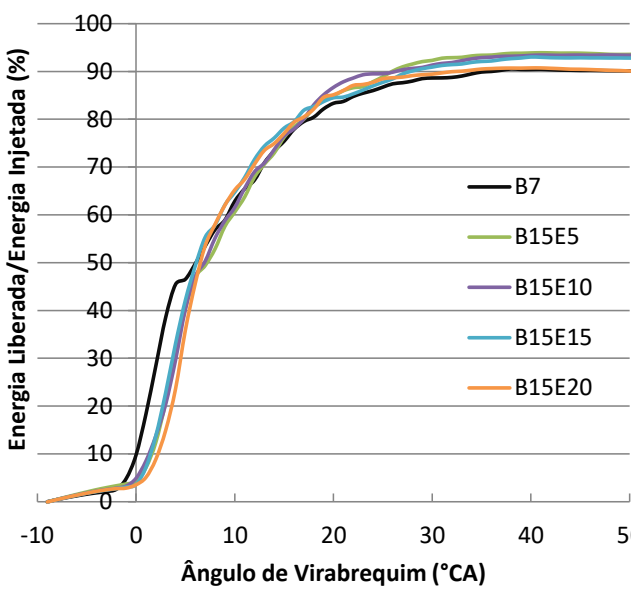

$50 \%$ do torque de B7 e 1800 RPM

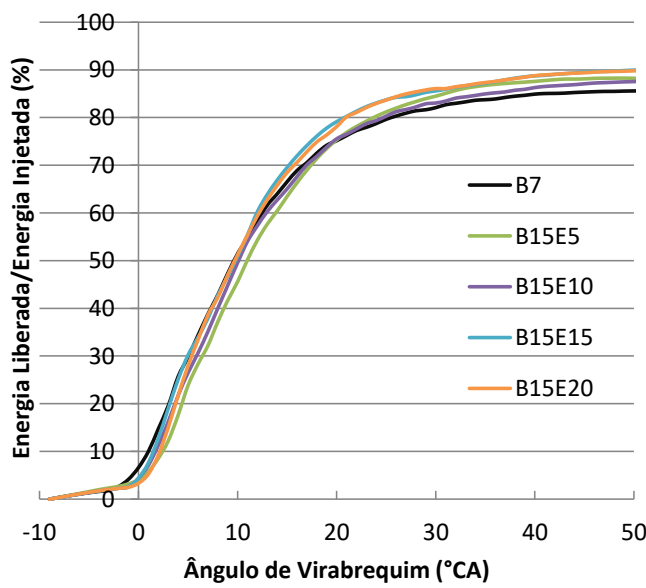

Figura 50 - Calor - 25\% e 50\% a 1800RPM - Otimização

25\% do torque de B7 e 2100 RPM

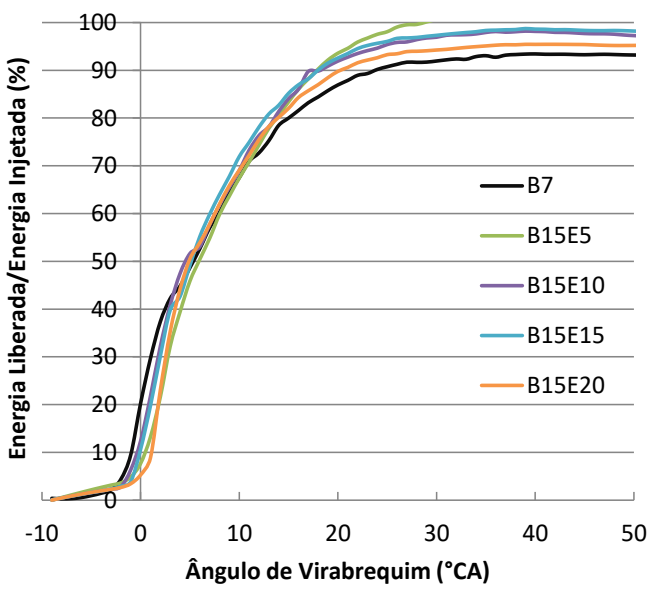

$50 \%$ do torque de B7 e 2100 RPM

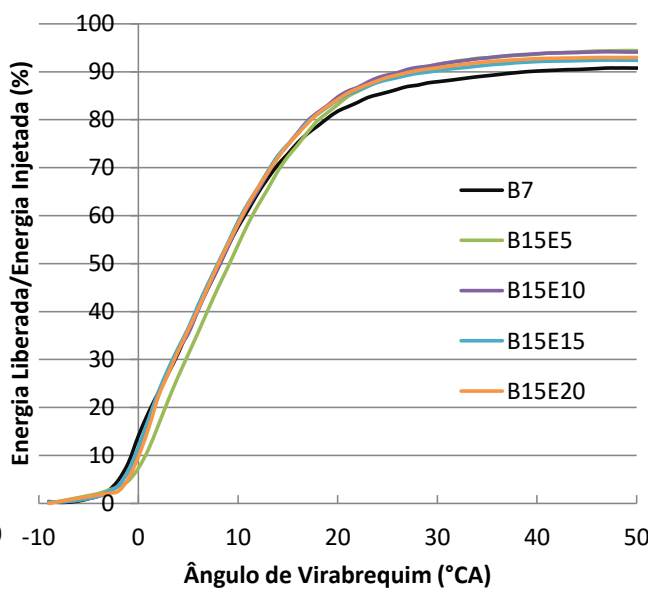

Figura 51 - Calor - 25\% e 50\% a 2100RPM - Otimização

Das curvas de pressão indicada (Figura 46, Figura 47 e Figura 48), podese depreender que a antecipação da injeção em misturas B15E15 e B15E20 
resultou em picos de pressão equivalentes à operação com diesel comercial B7, enquanto o atraso de injeção da mistura B15E5 a manteve com picos de pressão inferiores. Estes fatos comprovam que maiores picos de pressão não são obrigatoriamente sinônimos de torques, potências, BMEP e IMEP superiores numa avalição sob mesmas condições operacionais, vide valores apresentados no Anexo F. Muito embora, é importante esclarecer que, com os ajustes nos instantes de injeção de combustível, eventuais picos de pressão mais elevados mostram-se como consequências da necessidade do adiantamento das injeções nas situações em que as propriedades físico-químicas do etanol desfavoreçam a autoignição e atrasem a fase inicial da combustão.

Nas curvas de pressão indicada e liberação de calor com avanços de injeção fixos em 10,5 BTDC (Figura 32, Figura 33, Figura 34, Figura 36, Figura 37 e Figura 38), nota-se um distanciamento perceptível entre as curvas de misturas distintas devido aos efeitos do etanol nas combustões. Por outro lado, curvas de pressão indicada (Figura 46, Figura 47 e Figura 48) e liberação de calor (Figura 49, Figura 50 e Figura 51) com avanços de injeção otimizados, sugerem uma tendência de maior proximidade entre as curvas de diferentes misturas. Esta maior aproximação entre as curvas já indica minimizações da influência retardadora do etanol na combustão de misturas ternárias através do ajuste adequado para os instantes de injeção de combustível.

Neste âmbito, a quantificação do intervalo de tempo entre o avanço estático da injeção de combustível otimizado e o início da combustão vem com a intenção de complementar as observações feitas sobre as curvas de pressão indicada e calor liberado nos avanços ótimos. A Tabela 14 exibe, então, atrasos de ignição para as condições de $25 \%$ e $50 \%$ dos torques máximos de B7 com avanços otimizados. Já a Tabela 13, auxilia na interpretação dos resultados da Tabela 14, comparando os valores de atraso da ignição com avanços de $10,5^{\circ}$ BTDC e avanços otimizados, nas misturas em que esta comparação se aplica: B15E5, B15E15 e B15E20. 
Tabela 13 - Atraso da ignição e a modificação de avanços

\begin{tabular}{|c|c|c|c|c|c|c|}
\hline $\begin{array}{c}\text { Rotação } \\
\text { (RPM) }\end{array}$ & $\begin{array}{l}\text { B15E5 } \\
\left(10,5^{\circ}\right)\end{array}$ & $\begin{array}{l}\text { B15E5 } \\
\left(9,5^{\circ}\right)\end{array}$ & $\begin{array}{l}\text { B15E15 } \\
\left(10,5^{\circ}\right)\end{array}$ & $\begin{array}{c}\text { B15E15 } \\
\left(11,5^{\circ}\right)\end{array}$ & $\begin{array}{c}\text { B15E20 } \\
\left(10,5^{\circ}\right)\end{array}$ & $\begin{array}{l}\text { B15E20 } \\
\left(11,5^{\circ}\right)\end{array}$ \\
\hline \multicolumn{7}{|c|}{$25 \%$ dos torques máximos de $\mathrm{B} 7$} \\
\hline 1500 & $14,3^{\circ}$ & $14,3^{\circ}$ & $16,0^{\circ}$ & $16,7^{\circ}$ & $17,7^{\circ}$ & $17,3^{\circ}$ \\
\hline 1800 & $14,0^{\circ}$ & $13,7^{\circ}$ & $14,0^{\circ}$ & $14,3^{\circ}$ & $15,7^{\circ}$ & $14,7^{\circ}$ \\
\hline 2100 & $9,7^{\circ}$ & $9,7^{\circ}$ & $12,0^{\circ}$ & $11,7^{\circ}$ & $13,0^{\circ}$ & $13,0^{\circ}$ \\
\hline \multicolumn{7}{|c|}{$50 \%$ dos torques máximos de $\mathbf{B 7}$} \\
\hline 1500 & $14,0^{\circ}$ & $14,3^{\circ}$ & $17,3^{\circ}$ & $16,0^{\circ}$ & $17,3^{\circ}$ & $18,0^{\circ}$ \\
\hline 1800 & $14,3^{\circ}$ & $12,3^{\circ}$ & $14,3^{\circ}$ & $13,3^{\circ}$ & $15,0^{\circ}$ & $12,7^{\circ}$ \\
\hline 2100 & $9,0^{\circ}$ & $8,3^{\circ}$ & $9,7^{\circ}$ & $9,7^{\circ}$ & $11,7^{\circ}$ & $11,3^{\circ}$ \\
\hline
\end{tabular}

Os resultados apresentados na Tabela 13, comprovam que ajustes nos avanços de injeção de combustível influenciam diretamente a combustão, conforme fica explicitado nos atrasos da ignição desta tabela. Estes resultados mostram que, para as misturas ternárias com avanços ótimos de injeção diferentes de 10,5 BTDC, estes avanços otimizados permitiram atrasos da ignição até $15 \%$ menores.

Tabela 14 - Atraso da ignição - otimização

\begin{tabular}{|c|c|c|c|c|c|c|}
\hline $\begin{array}{c}\text { Rotação } \\
\text { (RPM) }\end{array}$ & B7 & B15E5 & B15E10 & B15E15 & B15E20 \\
\hline \multicolumn{7}{|c|}{$\mathbf{2 5 \%}$ dos torques } \\
\hline 1500 & $14,0^{\circ}$ & $14,3^{\circ}$ & $14,7^{\circ}$ & $16,7^{\circ}$ & $17,3^{\circ}$ \\
\hline 1800 & $11,0^{\circ}$ & $13,7^{\circ}$ & $15,0^{\circ}$ & $14,3^{\circ}$ & $14,7^{\circ}$ \\
\hline 2100 & $9,0^{\circ}$ & $9,7^{\circ}$ & $9,0^{\circ}$ & $11,7^{\circ}$ & $13,0^{\circ}$ \\
\hline 1500 & $\mathbf{5 0} \%$ dos torques máximos de B7 \\
\hline 1800 & $14,0^{\circ}$ & $14,3^{\circ}$ & $12,7^{\circ}$ & $16,0^{\circ}$ & $18,0^{\circ}$ \\
\hline 2100 & $9,7^{\circ}$ & $12,3^{\circ}$ & $10,7^{\circ}$ & $13,3^{\circ}$ & $12,7^{\circ}$ \\
\hline
\end{tabular}

Quando o conjunto dos atrasos da ignição da Tabela 14 é analisado, podese ratificar a tendência, já observada nas curvas de pressão indicada e calor liberado, de suave minimização dos efeitos de atraso causados pelo etanol no desenvolvimento do processo de combustão com diferentes misturas ternárias através de ajustes adequados nos instantes de injeção de combustível.

Portanto, os resultados de ambas as tabelas (Tabela 13 e Tabela 14) fornecem argumentos suficientes para a constatação de que a busca por avanços de injeção otimizados representa uma alternativa capaz de contornar efeitos indesejados do etanol relacionados ao atraso da ignição em misturas DBE, possibilitando, inclusive, uma elevação no patamar das eficiências térmicas obtidas no motor, de acordo com os resultados da Figura 43.

Finalmente, na Tabela 15 são exibidas diferenças entre CA90 e CA10 que 
estimam o intervalo entre o trecho inicial e final da combustão e permitem uma noção consistente a respeito da duração da combustão para os diferentes combustíveis com instantes de injeção otimizados (e condições de torque e rotação já predefinidas).

Tabela 15 - Intervalo entre CA90 e CA10 - otimização

\begin{tabular}{|c|c|c|c|c|c|c|}
\hline $\begin{array}{c}\text { Rotação } \\
\text { (RPM) }\end{array}$ & B7 & B15E5 & \multicolumn{1}{|c|}{ B15E10 } & B15E15 & B15E20 \\
\hline \multicolumn{7}{|c|}{$\mathbf{2 5 \%}$ dos torques } \\
\hline 1500 & $16,3^{\circ}$ & $17,0^{\circ}$ & $16,0^{\circ}$ & $15,7^{\circ}$ & $14,0^{\circ}$ \\
\hline 1800 & $19,0^{\circ}$ & $17,7^{\circ}$ & $17,0^{\circ}$ & $16,8^{\circ}$ & $15,3^{\circ}$ \\
\hline 2100 & $21,0^{\circ}$ & $19,0^{\circ}$ & $17,0^{\circ}$ & $18,7^{\circ}$ & $20,7^{\circ}$ \\
\hline & $\mathbf{5 0 \%}$ dos torques & máximos de B7 \\
\hline 1500 & $20,0^{\circ}$ & $20,3^{\circ}$ & $21,3^{\circ}$ & $18,6^{\circ}$ & $17,3^{\circ}$ \\
\hline 1800 & $22,3^{\circ}$ & $20,3^{\circ}$ & $23,0^{\circ}$ & $21,3^{\circ}$ & $21,3^{\circ}$ \\
\hline 2100 & $22,0^{\circ}$ & $21,3^{\circ}$ & $20,7^{\circ}$ & $20,0^{\circ}$ & $20,3^{\circ}$ \\
\hline
\end{tabular}

Assim como analisado na Tabela 9, em que os instantes de injeção de combustível eram fixos em $10,5^{\circ}$ BTDC, os resultados da Tabela 15 também sugerem uma tendência de redução do intervalo entre CA90 e CA10 com o crescimento da presença de etanol nas misturas. No entanto, para algumas condições e misturas, há um suave aumento do valor apresentado, em comparação com aqueles apresentados na situação de avanço de injeção fixo, justamente em virtude da otimização dos instantes de injeção combustível. Este acréscimo na duração da combustão pode ser considerado benéfico quando relacionado a suavizações nas taxas de liberação de calor, frequentemente exageradas, associadas à presença de etanol, conforme comentado nas teses de doutorado de Sánchez [58] e Pradelle [14].

Os ajustes nos instantes de injeção de combustível representam, por isso, um redimensionamento no desenvolvimento do processo de combustão de ignição por compressão, readequando condições favoráveis à autoignição na câmara em função das características físico-químicas de cada combustível e, com isso, viabilizando um melhor aproveitamento da energia contida no etanol, conforme já previsto e sugerido na tese de doutorado de Pradelle [14]. 


\section{6 \\ Conclusões e Recomendações}

Ao longo do presente trabalho, conduziu-se um estudo experimental em motor de ignição por compressão, acoplado a dinamômetro de bancada, com a intenção de investigar a substituição parcial do óleo diesel por biocombustíveis. O planejamento dos testes considerou algumas condições de rotação, torque e instantes de injeção de combustível na avaliação dos efeitos de diferentes proporções de etanol no desempenho e nas características de combustão quando o motor $\mathrm{Cl}$ é abastecido com misturas $\mathrm{DBE}$.

A seguir listam-se conclusões deste trabalho, bem como sugestões para estudos futuros que aprimorem os conhecimentos a cerca do tema abordado.

\section{1 \\ Conclusões}

- A presença de etanol restringiu a quantidade máxima de combustível fornecida pela bomba injetora e, por consequência, limitou a operação do motor em altas cargas. Para a operação em condição máxima da mistura de maior teor de etanol (B15E20), a bomba entregou volumes de combustível até 31\% menores, frente à operação de condição máxima com diesel comercial B7.

- Os consumos específicos de combustível dos testes com avanços da injeção fixados em 10,5 BTDC evidenciam o menor valor do poder calorífico do etanol frente ao diesel e biodiesel, já que o consumo específico de combustível aumenta com a introdução de etanol nas misturas. Já as curvas obtidas para pressão indicada e liberação de calor, bem como os resultados de atraso da ignição, mostram a tendência do etanol em postergar o início da ignição com o crescimento de sua participação nas misturas, comportamento que fomenta a investigação sobre otimização dos avanços da injeção de combustível.

- A busca por avanços ótimos na injeção de combustível constatou que no intervalo entre $5 \%$ e $15 \%$ de etanol nas misturas, cada $5 \%$ 
de acréscimo deste álcool na mistura ternária corresponderia à antecipação de um grau no avanço da injeção, conforme a Tabela 10 mostra para as misturas B15E5, B15E10 e B15E15. Por outro lado, a mistura B15E20 com concentração de $20 \%$ de etanol, estabilizou sua otimização do avanço de injeção com a mesma antecipação requerida pela mistura B15E15.

- As eficiências térmicas com o avanço da injeção fixado em $10,5^{\circ}$ BTDC já mostram, na Figura 31, que algumas condições operacionais de seletas misturas de combustível superam as eficiências térmicas alcançadas com o diesel comercial B7. Felizmente, a otimização da injeção de combustível revela na Figura 43 que as eficiências térmicas das misturas ternárias são capazes de ultrapassar, em quase todas as condições de operação, os resultados obtidos com o diesel comercial B7.

- Os resultados de eficiências térmicas do etanol em misturas ternárias com avanços de injeção ótimos, apresentados pela Figura 44 , deixam patentes as contribuições do etanol para o aumento das eficiências térmicas das misturas.

- Os consumos específicos energéticos de etanol nas misturas ternárias utilizadas no motor de ignição por compressão testado mostraram valores entre 6,1 e $11,6 \mathrm{MJ} / \mathrm{kWh}$, enquanto o motor de ignição por centelha da dissertação de Villela [121] apresentou uma faixa de valor de 10,7 a 13,5 MJ/kWh, a qual indica a necessidade de injeção de maiores quantidades de massas de etanol nas operações. Embora as condições operacionais avaliadas nas duas dissertações não sejam as mesmas, as faixas de valores dos resultados fornecem boa noção de quão vantajosa são as maiores razões de compressão dos motores de ignição por compressão perante os motores de ignição por centelha.

- Os atrasos da ignição das misturas em testes com avanços otimizados comprovaram indícios apontados pelas curvas de pressão indicada e liberação de calor, nas quais se sinalizou que ajustes do avanço de injeção puderam ao menos minimizar os efeitos retardadores do início da combustão causados pelo etanol. A tendência de redução do intervalo de atraso da ignição nos testes com avanços de injeção otimizados sugere a viabilização de 
condições mais adequadas à autoignição da carga no interior da câmara através das investigações dos avanços ótimos.

- A substituição parcial do óleo diesel pelos biocombustíveis em motores de ignição por compressão mostrou-se tecnicamente viável através da utilização de misturas ternárias compostas por diesel, biodiesel e etanol. Sem a exigência de modificações na estrutura ou geometria do motor, apenas ajustes no instante de injeção de combustível e a aplicação do aditivo formulado por Pradelle [14] na proporção de $1 \%$ foram suficientes para que até mesmo misturas com 20\% de participação de etanol (ou ainda 32\% de biocombustíveis: $20 \%$ etanol $+12 \%$ biodiesel) alcançassem eficiências térmicas superiores àquelas do diesel comercial B7.

\section{2 \\ Sugestões para Trabalhos Futuros}

- Substituição da bomba injetora distribuidora por um sistema de injeção de combustível via common-rail com atuação eletrônica para viabilização do fornecimento de combustível conforme demandado, mesmo quando houver etanol nas misturas. Adicionalmente, em sistemas de injeção eletrônica de common-rail não há mais sentido em diferenciarem-se os avanços de injeção entre estáticos e dinâmicos.

- Quantificação do poder calorífico de cada combustível com o auxílio de calorímetro para maior refinamento da exatidão dos resultados.

- Avaliação complementar com medições dos níveis de emissões de poluentes na ignição por compressão em motores abastecidos por misturas DBE.

- Investigações de outras combinações entre diesel, biodiesel e etanol com maiores concentrações de biodiesel para a maximização da substituição do óleo diesel por biocombustíveis.

- Estudo da potencialização das eficiências de motores abastecidos com misturas DBE através da investigação de razões de compressão. Tipicamente, os baixos índices de cetano do etanol permitem elevadas razões de compressão. 


\section{Referências Bibliográficas}

[1] Heywood, J. Internal Combustion Engines Fundamentals. McGraw-Hill Inc., 1988.

[2] Stone, R. Introduction to Internal Combustion Engines. 3ª́Edição, SAE Internacional e Macmillan Press, 1999.

[3] Goldenstein, M. \& Azevedo, R. L. S. Combustíveis Alternativos e Inovações no Setor Automotivo: Será o Fim da "Era do Petróleo"? BNDES Setorial, Rio de Janeiro, n. 23, pp. 235-266, 2006.

[4] Ccacya, A. O. R. Estudo Experimental da Ignição por Compressão de Misturas Homogêneas em Motores a Combustão Interna. Dissertação de Mestrado, Pontifícia Universidade Católica do Rio de Janeiro (PUC-Rio), Rio de Janeiro, Brasil, 2010.

[5] Empresa de Pesquisa Energética Balanço Energético Nacional 2016: Ano Base 2015. Rio de Janeiro, pp. 1-296, 2016.

[6] Brogio, J. R. Barreiras Internacionais ao Etanol Combustível. Dissertação de Mestrado, Universidade Federal do Rio de Janeiro, Rio de Janeiro, Brasil, 2009.

[7] Weber de Menezes, E., da Silva, R., Cataluña, R. \& Ortega, R. J. C. Effect of Ethers and Ether/Ethanol Additives on Physicochemical Properties of Diesel Fuel and on Engine Tests. Fuel, Vol.85, pp.815822, 2006. 
[8] Koike, G. H. A., Dal Bem, A. J. \& Passarini, L. C. Estudo da Utilização da Mistura de Etanol Anidro a 7\% em Motores de Ciclo Diesel sem Adição de Aditivos. Minerva, Vol.3 (1), pp. 83-92, 2006.

[9] Koike, G. H. A., Dal Bem, A. J. \& Passarini, L. C. Utilização de Etanol em Motores de Ciclo Diesel. Minerva, Vol.3 (2); pp. 141-149, 2007.

[10] Dondero, L. Z. Uso de Gás Natural em Veículos Leves e Mecanismo de Desenvolvimento Limpo no Contexto Brasileiro. Tese de Doutorado, Universidade de São Paulo, São Paulo, Brasil, 2002.

[11] Franco, J. A. A. Estudo Experimental de um Motor de Ignição por Compressão de Mistura Homogênea - HCCl. Dissertação de Mestrado, Pontifícia Universidade Católica do Rio de Janeiro (PUC-Rio), Rio de Janeiro, Brasil, 2011.

[12] Cummins Emission Solutions On-Highway Emissions Regulation. Indiana, Estados Unidos, 2012.

[13] Loaiza, J. C. V. Ignição por Compressão com Reatividade Controlada de Óleo Diesel e Etanol em Máquina de Compressão Rápida. Tese de Doutorado, Pontifícia Universidade Católica do Rio de Janeiro (PUC-Rio), Rio de Janeiro, Brasil, 2014.

[14] Pradelle, F. A. Y. Use of Biofuels in Compression Ignition Engines - Potential of Diesel-Biodiesel-Ethanol Blends. Tese de Doutorado, Pontifícia Universidade Católica do Rio de Janeiro (PUC-Rio), Rio de Janeiro, Brasil, 2017.

[15] Hanson, R. M. Experimental Investigation of Transient $\mathbf{R C C l}$ Combustion in a Light Duty Diesel Engine. Tese de PhD., University of Wisconsin-Madison, EUA, 2013. 
[16] Jarosinski, J. \& Veyssiere B. Combustion Phenomena. Boca Raton, Florida, Estados Unidos, Taylor \& Francis Group, LLC, 2009.

[17] Martínez, A. G. Estudio de los Efectos de La Post Inyección sobre El Proceso de Combustión y La Formación de Hollín en Motores Diésel. Tese de Doutorado, Universidad Politécnica de Valencia, Espanha, 2009.

[18] Shahabuddin, M., Liaquat, A. M., Masjuki, H. H., Kalam, M. A. \& Mofijur, M. Ignition Delay, Combustion and Emission Characteristics of Diesel Engine Fueled with Biodiesel. Renewable and Sustainable Energy Reviews, Vol.21, pp.623-632, 2013.

[19] Petrobras Distribuidora S.A. Ficha de Informação de Segurança de Produtos Químicos - FISPQ, Óleo Diesel S 10, Versão 6, 2015.

[20] Taylor, C. F. Análise dos Motores de Combustão Interna. 1ªEdição, Edgard Blucher, 1976.

[21] Egúsquiza, J. C. C. Redução das Emissões em Motores DieselGás. Dissertação de Mestrado, Pontifícia Universidade Católica do Rio de Janeiro (PUC-Rio), Rio de Janeiro, Brasil, 2006.

[22] Bambrila, J. A. Estudo Experimental e Simulação Termodinâmica de Desempenho em um Motor de Combustão Interna Operando com Óleo Diesel e Etanol. Dissertação de Mestrado, Universidade de São Paulo (USP), São Paulo, Brasil, 2006.

[23] Obert, E. F. Motores de Combustão Interna. 2ªEdição, Editora Globo, 1971.

[24] Ferrari Filho, F. Análise de um Motor Ciclo Diesel Operando no Modo Bicombustível: Diesel/Etanol. Dissertação de Mestrado, Pontifícia Universidade Católica (PUC-Rio), Rio de Janeiro, Brasil, 2011. 
[25] Romano, S. D. \& Sorichetti, P. A. Dielectric Spectroscopy in Biodiesel Production and Characterization. Green Energy and Technology, DOI: 10.1007/978-1-84996-519-4_2, Springer-Verlag London Limited, 2011.

[26] Pousa, G. P. A. G, Santos, A. L. F. \& Suarez, P. A. Z. History and Policy of Biodiesel in Brazil. Energy Policy, Vol.35, pp. 5393-5398, 2007.

[27] Ballerini, D. Le Plein de Biocarburants? - Enjeux et Réalités. Ed. Technip, 2007.

[28] Pang, X., Shi, X., Mu, Y., He, H., Shuai, S., Chen, H. \& Li, R. Characteristics of Carbonyl Compounds Emission from a DieselEngine Using Biodiesel-Ethanol-Diesel as Fuel. Atmospheric Environment, Vol.40, pp. 7057-7065, 2006.

[29] Shi, X., Pang, X., Mu, Y., He, H., Shuai, S., Wang, J., Chen, H. \& Li, R. Emission Reduction Potential of Using Ethanol-Biodiesel-Diesel Fuel Blend on a Heavy-Duty Diesel Engine. Atmospheric Environment, Vol.40, pp. 2567-2574, 2006.

[30] Pidol, L., Lecointe, B., Starck, L. \& Jeuland, N. Ethanol-BiodieselDiesel Fuel Blends: Performances and Emissions in Conventional Diesel and Advanced Low Temperature Combustions. Fuel, Vol.93, pp. 329-338, 2012.

[31] Egúsquiza, J. C. C. Avaliação Experimental de um Motor Ciclo Diesel Operando no Modo Biocombustível: Diesel/Etanol e Diesel/Gás. Tese de Doutorado, Pontifícia Universidade Católica do Rio de Janeiro (PUC-Rio), Rio de Janeiro, Brasil, 2011. 
[32] Carneiro, M. L. N. M., Pradelle, F., Braga, S. L., Gomes, M. S. P., Martins, A. R. F. A., Turkovics, F. \& Pradelle, R. N. C. Potential of Biofuels from Algae: Comparison with Fossil Fuels, Ethanol and Biodiesel in Europe and Brazil through Life Cycle Assessment (LCA). Renewable and Sustainable Energy Reviews, Vol.73, pp.632-653, 2017.

[33] Petrobras Distribuidora S.A. Ficha de Informação de Segurança de Produto Químico - FISPQ, Etanol Anidro Combustível EAC, Versão 6, 2015.

[34] Petrobras Distribuidora S.A. Ficha de Informação de Segurança de Produto Químico - FISPQ, Etanol Hidratado Combustível EHC, Versão 6, 2015.

[35] Hardenberg, H. \& Schaefer, J. A. The use of Ethanol as a Fuel for Compression-Ignition Engines. SAE Technical Paper 811211, 1981.

[36] Abu-Qudais, M., Haddad, O. \& Qudaisat, M. The Effect of Alcohol Fumigation on Diesel Engine Performance and Emissions. Energy Conversion \& Management, Vol.41, pp.389-399, 2000.

[37] Alperstein, M., Swim, W. B. \& Schweitzer, P. H. Fumigation Kills Smoke - Improves Diesel Performance. SAE Technical Paper 580058, 1958.

[38] Bessonette P. W., Schleyer C. H., Duffy K. P., Hardy W. L. \& Liechty M. P. Effects of Fuel Property Changes on Heavy-Duty HCCI Combustion. SAE Technical Paper 2007-01-0191, 2007.

[39] Inagaki, K., Fuyuto, T., Nishikawa, K., Nakakita, K. \& Sakata I., Dual Fuel PCI Combustion Controlled by In-Cylinder Stratification of Ignitability. SAE Technical Paper 2006-01-0028, 2006. 
[40] Kokjohn, S. L., Hanson, R. M., Splitter, D. A. \& Reitz, R. D. Fuel Reactivity Controlled Compression Ignition (RCCl): A Pathway to Controlled High-efficiency Clean Combustion. International Journal of Engine Research, Vol.12, pp. 209-226, 2011.

[41] Kokjohn, S., Hanson, R., Splitter, D. \& Reitz, R. Experiments and Modeling of Dual-Fuel $\mathrm{HCCl}$ and $\mathrm{PCCl}$ Combustion Using In-Cylinder Fuel Blending. SAE Technical Paper 2009-01-2647, 2009.

[42] Curran, S., Gao, Z. \& Wagner, R. Reactivity Controlled Compression Ignition Drive Cycle Emissions and Fuel Economy Estimations Using Vehicle Systems Simulations with E30 and ULSD. SAE Technical Paper 2014-01-1324, 2014.

[43] Kokjohn, S. L. Reactivity Controlled Compression Ignition (RCCl) Combustion. Tese de PhD., University of Wisconsin-Madison, EUA, 2012.

[44] Asad, U., Kumar, R., Zheng, M. \& Tjong, J. Ethanol-Fueled Low Temperature Combustion: A Pathway to Clean and Efficient Diesel Engine Cycles. Applied Energy, 2015.

[45] Curran, S., Hanson, R. \& Wagner, R. Effect of E85 on RCCl Performance and Emissions on a Multi-Cylinder Light-Duty Diesel Engine. SAE Technical Paper 2012-01-0376, 2012.

[46] Splitter, D., Hanson, R., Kokjohn, S. \& Reitz, R. Reactivity Controlled Compression Ignition (RCCl) Heavy-Duty Engine Operation at Mid and High-Loads with Conventional and Alternative Fuels. SAE Technical Paper 2011-01-0363, 2011.

[47] Sarjovaara, T., Larmi, M. \& Vuorinen, V. Effect of Charge Air Temperature on E85 Dual-Fuel Diesel Combustion. Fuel, Vol.153, pp.612, 2015. 
[48] Benajes, J., Molina, S., García, A. \& Monsalve-Serrano, J. Effects of Direct Injection Timing and Blending Ratio on RCCl Combustion with Different Low Reactivity Fuels. Energy Conversion and Management, Vol.99, pp.193-209, 2015.

[49] Wissink, M., Wang, Z., Splitter, D., Shahlari, A. \& Reitz, R. Investigation of Pressure Oscillation Modes and Audible Noise in RCCl, HCCl and CDC. SAE Technical Paper 2013-01-1652, 2013.

[50] Wissink, M. L., Lim, J. H., Splitter, D. A, Hanson, R. M. \& Reitz, R. D. Investigation of Injection Strategies to Improve High Efficiency RCCI Combustion with Diesel and Gasoline Direct Injection. ASME Internal Combustion Engine Division Fall Technical Conference, Vancouver (B.C.), Canada, 2012.

[51] Bandel, W. A Review of the Possibilities of Using Alternative Fuels in Commercial Vehicle Engines. Resources and Conservation, Vol.10, pp.135-160, 1983.

[52] Kolodziej, C., Wissink, M., Splitter, D., Hanson, R., Reitz, R. \& Benajes, J. Particle Size and Number Emissions from RCCl with Direct Injections of Two Fuels. SAE Technical Paper 2013-01-1661, 2013.

[53] Reitz, R. D. \& Duraisamy, G. Review of High Efficiency and Clean Reactivity Controlled Compression Ignition (RCCl) Combustion in Internal Combustion Engines. Progress in Energy and Combustion Science, Vol.46, pp.12-71, 2015.

[54] Wissink, M.L., Lim, J.H., Splitter, D.A., Hanson, R.M. \& Reitz, R.D. Investigation of Injection Strategies to Improve High Efficiency $\mathrm{RCCl}$ Combustion with Diesel and Gasoline Direct Injection. Paper 
ICEF2012-92107, Proceedings of ASME Internal Combustion Engine Division Fall Technical Conference, Vancouver, Canada, 2012.

[55] Yilmaz, N., Donaldson, A. B. \& Johns, A. Some Perspectives on Alcohol Utilization in a Compression Ignition Engine. SAE Technical Paper 2005-01-3135, 2005.

[56] Motta, G. P. O. Análise de Alternativas e Impactos para Substituição do Diesel por Etanol no Processo de Produção Sucroalcooleiro. Monografia de Graduação, Universidade de São Paulo (USP), São Paulo, 2011.

[57] Hardenberg, H. O. \& Schaefer, A. J. The Use of Ethanol as a Fuel for Compression Ignition Engines. SAE Technical Paper 811211, 1981.

[58] Sánchez, F. Z. Ignição por Compressão de Etanol Aditivado em uma Máquina de Compressão Rápida. Tese de Doutorado, Pontifícia Universidade Católica (PUC-Rio), Rio de Janeiro, Brasil, 2016.

[59] Velázquez, S. M. S. G., Santos, S. M. A., Moreira, J. R., Melo, E. H. \& Coelho, S. T. O Projeto BEST - BioEtanol para o Transporte Sustentável - Uma Contribuição ao Meio Ambiente das Metrópoles. XIII Congresso Brasileiro de Energia, São Paulo, Brasil, 2010.

[60] Ecklund, E., Bechtold, R., Timbario, T. \& McCallum, P. State-ofthe-Art Report on the Use of Alcohols in Diesel Engines. SAE Technical Paper 840118, 1984.

[61] Shahir, S. A., Masjuki, H. H., Kalam, M. A., Imran, A., Fattah, I. M. R. \& Sanjid, A. Feasibility of Diesel-Biodiesel-Ethanol/Bioethanol Blend as Existing $\mathrm{Cl}$ Engine Fuel: An Assessment of Properties, Material Compatibility, Safety and Combustion. Renewable and Sustainable Energy Reviews, Vol.32, pp. 379-395, 2014. 
[62] Balat, M. \& Balat, H. A Critical Review of Bio-Diesel as a Vehicular Fuel. Energy Conversion and Management, Vol.49, pp. 27272741, 2008.

[63] Murugesan, A., Umarani, C., Subramanian, R. \& Nedunchezhian, N. Bio-Diesel as an Alternative Fuel for Diesel Engines - A Review. Renewable and Sustainable Energy Reviews, Vol.13, pp. 653-662, 2009.

[64] Jain, S. \& Sharma, M. P. Prospects of Biodiesel from Jatropha in India: A Review. Renewable and Sustainable Energy Reviews, Vol.14, pp. 763-771, 2010.

[65] Rajasekar E., Murugesan, A., Subramanian, R. \& Nedunchezhian N. Review of $\mathrm{NO}_{x}$ Reduction Technologies in $\mathrm{Cl}$ Engines Fuelled with Oxygenated Biomass Fuels. Renewable and Sustainable Energy Reviews, Vol.14, pp.2113-2121, 2010.

[66] Jayed, M. H., Masjuki, H. H., Kalam, M. A., Mahlia, T. M. I., Husnawan, M. \& Liaquat, A. M. Prospects of Dedicated Biodiesel Engine Vehicles in Malaysia and Indonesia. Renewable and Sustainable Energy Reviews, Vol.15, pp. 220-235, 2011.

[67] Ong, H. C., Mahlia, T. M. I., Masjuki, H. H. \& Norhasyima, R. S. Comparison of Palm Oil, Jatropha Curcas and Calophyllum Inophyllum for Biodiesel: A review. Renewable and Sustainable Energy Reviews, Vol.15, pp. 3501-3515, 2011.

[68] Xue, J., Grift, T. E. \& Hansen, A. C. Effect of Biodiesel on Engine Performances and Emissions. Renewable and Sustainable Energy Reviews, Vol.15, pp. 1098-1116, 2011.

[69] Mehta, R. N., Chakraborty, M. \& Parikh, P. A. Comparative Study of Stability and Properties of Alcohol-Diesel Blends. Indian Journal of Chemical Technology, Vol.19, pp. 134-139, 2012. 
[70] Mofijur M., Masjuki, H. H., Kalam, M. A., Hazrat, M. A., Liaquat, A. M. \& Shahabuddin, M. Prospects of Biodiesel from Jatropha in Malaysia. Renewable and Sustainable Energy Reviews, Vol.16, pp. 5007-5020, 2012.

[71] Adelman, H. G. \& Pefley, R. K. Utilization of Pure Alcohol Fuels in a Diesel Engine by Spark Ignition. IV International Symposium on Alcohol Fuels, São Paulo, Brasil, 1980.

[72] Caro, P. S., Mouloungui, Z., Vaitilingom, G. \& Berge, J. C. Interest of Combining an Additive with Diesel-Ethanol Blends for Use in Diesel Engines. Fuel, Vol.80, pp.565-574, 2001.

[73] Strait, J., Boedicker, J. \& Johansen, K. Diesel Oil and Ethanol Mixtures for Diesel-Powered Farm Tractors. SAE Technical Paper 790958, 1979.

[74] Meiring, P., Allan, R. S., Hansen, A. C. \& Lyne, P. W. L. Tractor Performance and Durability with Ethanol-Diesel Fuel. Transactions of the ASAE, Vol.26, pp.59-62, 1983.

[75] Hansen, A. C., Lyne, P. W. L. \& Zhang, Q. Ethanol-Diesel Blends: A Step Towards a Bio-Based Fuel for Diesel Engines. ASAE Paper 2001-01-6048, Vol.1, pp.1-14, 2001.

[76] Silva, N. R. D. Metodologia para Determinação da Potência Indicada em Motores de Combustão Interna. Dissertação de Mestrado, Universidade Estadual de Campinas, São Paulo, Brasil, 2006.

[77] Waterland, L. R., Venkatesh, S. \& Unnasch, S. Safety and Performance Assessment of Ethanol/Diesel Blends (E-Diesel). Subcontractor Report, National Renewable Energy Laboratory, EUA, 2003. 
[78] Ribeiro, N. M., Pinto, A. C., Quintella, C. M., da Rocha, G. O., Teixeira, L. S. G., Guarieiro, L. L. N., Rangel, M. C., Veloso, M. C. C., Rezende, M. J. C., da Cruz, R. S., de Oliveira, A. M., Torres, E. A. \& de Andrade, J. B. The Role of Additives for Diesel and Diesel Blended (Ethanol or Biodiesel) Fuels: A Review. Energy \& Fuels, Vol.21, pp. 2433-2445, 2007.

[79] Guarieiro, L. L. N., de Souza, A. F., Torres, E. A. \& de Andrade, J. B. Emission Profile of 18 Carbonyl Compounds, $\mathrm{CO}, \mathrm{CO}_{2}$, and $\mathrm{NO}_{\mathrm{x}}$ Emitted by a Diesel Engine Fuelled with Diesel and Ternary Blends Containing Diesel, Ethanol and Biodiesel or Vegetable Oils. Atmospheric Environment, Vol.43, pp. 2754-2761, 2009.

[80] Can, Ö., Çelikten, I. \& Usta, N. Effects of Ethanol Addition on Performance and Emissions of a Turbocharged Indirect Injection Diesel Engine Running at Different Injection Pressures. Energy Conversion and Management, Vol.45, pp.2429-2240, 2004.

[81] Reyes, Y. Combustíveis Alternativos: Mistura de Etanol Anidro ao Óleo Diesel para Motores de Ciclo Diesel com Sistema de Injeção de Bomba Rotativa. Tese de Doutorado, Universidade Federal do Rio de Janeiro (UFRJ), Rio de Janeiro, Brasil, 2009.

[82] Reyes, Y., Aranda, D. A. G., Santander, L. A. M., Cavado, A. \& Belchior, C .R. P. Action Principles of Co-solvent Additives in EthanolDiesel Blends: Stability Studies. Energy \& Fuels, Vol.23, pp. 27312735, 2009.

[83] Fazal, M. A., Haseeb, A. S. M. A. \& Masjuki, H. H. Biodiesel Feasibility Study: An Evaluation of Material Compatibility; Performance; Emission and Engine Durability. Renewable and Sustainable Energy Reviews, Vol.15, pp. 1314-1324, 2011. 
[84] Fernando, S. \& Hanna, M. Development of a Novel Biofuel Blend Using Ethanol-Biodiesel-Diesel Microemulsions: EB-Diesel. Energy \& Fuels, Vol.18, pp. 1695-1703, 2004.

[85] Shi, X., Yu, Y., He, H., Shuai, S., Wang, J. \& Li, R. Emission Characteristics Using Methyl Soyate-Ethanol-Diesel Fuel Blends on a Diesel Engine. Fuel, Vol.84, pp. 1543-1549, 2005.

[86] Kwanchareon, P., Luengnaruemitchai, A. \& Jai-In, S. Solubility of a Diesel-Biodiesel-Ethanol Blend, Its Fuel Properties, and Its Emission Characteristics from Diesel Engine. Fuel, Vol.86, pp.10531061, 2007.

[87] Lapuerta, M., Armas, O. \& García-Contreras, R. Effect of Ethanol on Blending Stability and Diesel Engine Emissions. Energy \& Fuels, Vol.23, pp. 4343-4354, 2009.

[88] Rahimi, H., Ghobadian, B., Yusaf, T., Najafi, G. \& Khatamifar, M. Diesterol: An Environment-Friendly IC Engine Fuel. Renewable Energy, Vol.34, pp. 335-342, 2009.

[89] Shudo, T., Nakajima, T. \& Hiraga, K. Simultaneous Reduction in Cloud Point, Smoke, and $\mathrm{NO}_{x}$ Emissions by Blending Bioethanol into Biodiesel Fuels and Exhaust Gas Recirculation. International Journal of Engine Research, Vol.10, pp. 15-26, 2009.

[90] Chotwichien, A., Luengnaruemitchai, A. \& Jai-In, S. Utilization of Palm Oil Alkyl Esters as an Additive in Ethanol-Diesel and ButanolDiesel Blends. Fuel, Vol.88, pp. 1618-1624, 2009.

[91] Randazzo, M. L. \& Sodré, J. R. Cold Start and Fuel Consumption of a Vehicle Fuelled with Blends of Diesel Oil-Soybean BiodieselEthanol. Fuel, Vol.90, pp. 3291-3294, 2011. 
[92] Randazzo, M. L. \& Sodré, J. R. Exhaust Emissions from a Diesel Powered Vehicle Fuelled by Soybean Biodiesel Blends (B3-B20) with Ethanol as an Additive (B20E2-B20E5). Fuel, v.90: p. 98-103, 2011.

[93] Torres-Jimenez, E., Jerman, M. S., Gregorc, A., Lisec, I., Dorado, M. P. \& Kegl, B. Physical and Chemical Properties of Ethanol-Diesel Fuel Blends. Fuel, Vol.90, pp. 795-802, 2011.

[94] Yilmaz, N., Vigil, F. M., Donaldson, A. B. \& Darabseh, T. Investigation of $\mathrm{Cl}$ Engine Emissions in Biodiesel-Ethanol-Diesel Blends as a Function of Ethanol Concentration. Fuel, Vol.115, pp. 790-793, 2014.

[95] Makareviciene, V., Sendzikiene, E. \& Janulis, P. Solubility of Multi-Component Biodiesel Fuel Systems. Bioresource Technology, Vol.96, pp. 611-616, 2005.

[96] Hulwan, D. B. \& Joshi, S. V. Performance, Emission and Combustion Characteristic of a Multicylinder DI Diesel Engine Running on Diesel-Ethanol-Biodiesel Blends of High Ethanol Content. Applied Energy, Vol.88, pp. 5042-5055, 2011.

[97] Fang, Q., Fang, J., Zhuang, J. \& Huang, Z. Effects of EthanolDiesel-Biodiesel Blends on Combustion and Emissions in Premixed Low Temperature Combustion. Applied Thermal Engineering, Vol.54, pp.541-548, 2013.

[98] Ali, Y., Hanna, M. A. \& Borg, J. E. Optimization of Diesel, Methyl Tallowate and Ethanol Blend for Reducing Emissions from Diesel Engine. Bioresource Technology, Vol.52, pp. 237-243, 1995.

[99] Park, S. H., Kim, S. H. \& Lee, C. S. Mixing Stability and Spray Behaviour Characteristics of Diesel-Ethanol-Methyl Ester Blended 
Fuels in a Common-Rail Diesel Injection System. Energy \& Fuels, Vol.23, pp. 5228-5235, 2009.

[100] Qi, D. H., Chen, H., Lee, C. F., Geng, L. M. \& Bian, Y. Z. Experimental Studies of a Naturally Aspirated DI Diesel Engine Fuelled with Ethanol-Biodiesel-Water Microemulsions. Energy \& Fuels, Vol.24, pp. 652-663, 2010.

[101] Kannan, G. R. Effect of Injection Pressures and Timings on the Performance Emission and Combustion Characteristics of a Direct Injection Diesel Engine Using Biodiesel-Diesel-Ethanol Blend. SAE Technical Paper 2013-01-1699, 2013.

[102] Park, S. H., Cha, J. \& Lee, C. S. Impact of Biodiesel in Bioethanol Blended Diesel on the Engine Performance and Emissions Characteristics in Compression Ignition Engine. Applied Energy, Vol.99, pp. 334-343, 2012.

[103] Barabás, I., Todoruţ, A. \& Băldean, D. Performance and Emission Characteristics of an $\mathrm{Cl}$ Engine Fueled with Diesel-BiodieselBioethanol Blends. Fuel, Vol.89, pp. 3827-3832, 2010.

[104] Barabás, I. \& Todoruţ, A. Utilization of Biodiesel-Diesel-Ethanol Blends in Cl Engine. Em: Montero, G. \& Stoytcheva, M. Biodiesel Quality, Emissions and By-Products, Ed. InTech, pp. 215-234, 2011.

[105] Suppes, G. J. Past Mistakes and Future Opportunities of Ethanol in Diesel. Buffalo, Bioenergy, 2000.

[106] He, B. - Q., Shuai, S. - J., Wang, J. - X. \& He, H. The Effect of Ethanol Blended Diesel Fuels on Emissions from a Diesel Engine. Atmospheric Environment, Vol.37, pp. 4965-4971, 2003. 
[107] Aakko, P., Nylund, N. - O., Westerholm, M., Marjamäki, M., Moisio, M., Hillamo, R \& Mäkelä, T. Emissions from Heavy-Duty Engine with and without After Treatment Using Selected Biofuels. Em: FISITA 2002 World Automotive Congress Proceedings. Helsinki, Finland, 2002.

[108] Li, D. - G., Zhen, H., Xingcai, L., Wu-gao, Z. \& Jian-guang, Y. Physico-Chemical Properties of Ethanol-Diesel Blend Fuel and Its Effect on Performance and Emissions of Diesel Engines. Renewable Energy, Vol.30; pp. 967-976, 2005.

[109] Rakopoulos, C. D., Antonopoulos, K. A. \& Rakopoulos, D. C. Experimental Heat Release Analysis and Emissions of a HSDI Diesel Engine Fueled with Ethanol-Diesel Fuel Blends. Energy, Vol.32, pp. 1791-1808, 2007.

[110] Lebedevas, S., Lebedeva, G., Makareviciene, V., Janulis, P. \& Sendzikiene, E. Usage of Fuel Mixtures Containing Ethanol and Rapeseed Oil Methyl Esters in a Diesel Engine. Energy \& Fuels, Vol. 23, pp. 217-223, 2009.

[111] Park, S. H., Cha, J. \& Lee, C. S. Effects of Bioethanol-Blended Diesel Fuel on Combustion and Emission Reduction Characteristics in a Direct-Injection Diesel Engine with Exhaust Gas Recirculation (EGR). Energy \& Fuels, Vol.24, pp. 3872-3883, 2010.

[112] Rakopoulos, D. C., Rakopoulos, C. D., Papagiannakis, R. G \& Kyritsis, D. C. Combustion Heat Release Analysis of Ethanol or $\mathbf{n -}$ Butanol Diesel Fuel Blends in Heavy-Duty DI Diesel Engine. Fuel, Vol.90, pp. 1855-1867, 2011.

[113] Lei, J., Shen, L., Bi, Y. \& Chen, H. A Novel Emulsifier for Ethanol-Diesel Blends and Its Effect on Performance and Emissions of Diesel Engine. Fuel, Vol.93, pp. 305-311, 2012. 
[114] Pereira, R. H. Avaliação Experimental e Previsão do Desempenho de Motores Diesel Consumindo Gás Natural. Tese de Doutorado, Pontifícia Universidade Católica do Rio de Janeiro (PUC-Rio), Rio de Janeiro, Brasil, 2006.

[115] MWM International Motores (A Navistar Company). Manual de Oficina - Série 10. ASC Comunicação Técnica, 2007.

[116] Pradelle, R. N. C., Turkovics, F., Airoldi, M. L., Serralvo Neto, R., Braga, S. L., Pradelle, F. \& Martins, A. R. F. A. Additif pour carburant comprenant um mélange de gazole et d'au moins un álcool de type éthanol. Pedido de patente registrado no Institut National de la Propriété Industrielle (INPI, França), n 1000393998, 2017.

[117] Crowell, T. J. Evaluation of Enhanced Ethanol with Fumigation as a Diesel Fuel Replacement. American Society of Mechanical Engineers, Journal Volume, Vol. 41(5), pp. 1249-1253, 1989.

[118] Reddy, P. R., Krishna D. M., Mallan K. R. G. \& Ganesan V. Evaluation of Combustion Parameters in Direct Injection Diesel Engine - An Easy and Reliable Method. SAE Technical Paper 930605, 1993.

[119] Merker, G. P., Schwarz, C., Stiesch, G. \& Otto, F. Simulating Combustion - Simulation of Combustion and Pollutant Formation for Engine-Development. $1^{\text {a }}$ Edição, Wiesbaden - Alemanha: SpringerVerlag Berlin Heidelberg, 2004.

[120] Tazerout, M. \& Le Corre, O. A New Method to Determine the Start and End of Combustion in an Internal Combustion Engine Using Entropy Changes. International Journal Applied Thermodynamics, Vol.3, pp.49-55, 2000. 
[121] Villela, A. C. S. Desempenho e Combustão de Etanol Anidro e Hidratado em Motor Multicombustível. Dissertação de Mestrado, Pontifícia Universidade Católica do Rio de Janeiro (PUC-Rio), Rio de Janeiro, Brasil, 2010.

[122] Borgnakke, C. \& Sonntag, R. E. Fundamentals of Thermodynamics. $7^{\mathrm{a}}$ Edição, John Wiley \& Sons Inc., 2009.

[123] INMETRO Guia para a Expressão de Incerteza de Medição (GUM) Avaliação de Dados de Medição. $1^{\text {a }}$ Edição Brasileira da $1^{\underline{a}}$ Edição do BIPM de 2008: Evaluation of Measurement Data - Guide to the Expression of Uncertainty in Measurement, 2012.

[124] De Melo, T. C. C. Análise Experimental e Simulação Computacional de um Motor Flex Operando com Diferentes Misturas de Etanol Hidratado na Gasolina. Tese de Doutorado, Universidade Federal do Rio de Janeiro (UFRJ), Rio de Janeiro, Brasil, 2012.

[125] Moffat, R. J. Describing the Uncertainties in Experimental Results. Experimental Thermal and Fluid Science, Vol. 1, pp. 3-17, 1988.

[126] Fox, R. W., Pritchard, P. J. \& McDonald, A. T. Introduction to Fluid Mechanics. $7^{a}$ Edição, John Wiley \& Sons Inc., 2010.

[127] CIBSE. Guide C: Reference Data 2007. Chartered Institution of Building Services Engineers (CIBSE), 2007. 


\section{Apêndices}

A.

\section{Propriedades Físico-Químicas}

\begin{tabular}{|c|c|c|}
\hline Propriedades & Diesel $^{(1)}$ & Etanol Anidro $^{(1)(2)}$ \\
\hline Fórmula Química Principal & $\mathrm{C}_{12} \mathrm{H}_{26}$ & $\mathrm{C}_{2} \mathrm{H}_{5} \mathrm{OH}$ \\
\hline Relação Atômica H/C do Combustível & 1,85 & 3 \\
\hline Massa Molecular & $170 \mathrm{~g} / \mathrm{mol}$ & $46 \mathrm{~g} / \mathrm{mol}$ \\
\hline Massa Específica (@ 293K e 1 atm) & $830 \mathrm{~kg} / \mathrm{m}^{3}$ & $790 \mathrm{~kg} / \mathrm{m}^{3}$ \\
\hline Temperatura de Autoignição & $254^{\circ} \mathrm{C}$ & $420^{\circ} \mathrm{C}$ \\
\hline Viscosidade (@300K) & $3,71 \mathrm{cSt}$ & $1,78 \mathrm{cSt}$ \\
\hline Número de Cetano & 45 a $50^{(3)}$ & 5 a $8^{(3)}$ \\
\hline Calor Latente de Vaporização & $250 \mathrm{~kJ} / \mathrm{kg}$ & $903 \mathrm{~kJ} / \mathrm{kg}$ \\
\hline Poder Calorífico Inferior & $45,71 \mathrm{MJ} / \mathrm{kg}^{(3)}$ & $26,87 \mathrm{MJ} / \mathrm{kg}$ \\
\hline
\end{tabular}

(1) Informação disponível na dissertação de mestrado de Ferrari Filho [24].

(2) Teor alcóolico mínimo de 99,5\% e teor máximo de $\mathrm{H}_{2} \mathrm{O}$ de $0,2 \%$ (em volume).

(3) Informação disponível na tese de doutorado de Pradelle [14].

\begin{tabular}{c|cc}
\hline Propriedades do Biodiesel & Origem: Soja $^{(3)}$ & Origem: Sebo Bovino $^{(3)}$ \\
\hline Massa Específica & $878,1 \mathrm{~kg} / \mathrm{m}^{3}$ & $876,4 \mathrm{~kg} / \mathrm{m}^{3}$ \\
Poder Calorífico Inferior & $37,6 \mathrm{MJ} / \mathrm{kg}$ & $38,2 \mathrm{MJ} / \mathrm{kg}$ \\
\hline
\end{tabular}

(3) Informação disponível na tese de doutorado de Pradelle [14].

\begin{tabular}{c|c}
\hline Propriedades (@ 1atm e 298K) & $\boldsymbol{A r}^{(4)}$ \\
\hline Massa Específica & $1,169 \mathrm{~kg} / \mathrm{m}^{3}$ \\
Calor Específico $\left(c_{p}\right)$ a Pressão Constante & $1,004 \mathrm{~kJ} / \mathrm{kgK}$ \\
Calor Específico $\left(c_{\mathrm{v}}\right)$ a Volume Constante & $0,717 \mathrm{~kJ} / \mathrm{kgK}$ \\
Razão $(\gamma)$ entre Calores Específicos $\left(c_{\mathrm{p}} / \mathrm{c}_{\mathrm{v}}\right)$ & 1,4 \\
Constante Universal dos Gases Ideais para o Ar & $0,287 \mathrm{~kJ} / \mathrm{kgK}$ \\
\hline
\end{tabular}

${ }^{(4)}$ Informação disponível na literatura de Borgnakke et al. [122]. 


\section{B. \\ Fatores de Correção da Vazão Volumétrica de Ar Úmido}

A eq. (9) do item 4.4 utiliza-se de uma série de fatores de correção para viscosidade, temperatura, pressão e massa específica na estimativa da vazão volumétrica de ar úmido. Então, o fator da viscosidade dinâmica, que relaciona a viscosidade dinâmica do ar seco nas condições de referência com a viscosidade dinâmica de ar úmido, é dado pela eq. (B.1):

$$
\left(\frac{\mu_{r}}{\mu_{a r, u}}\right)=\frac{1,84 \cdot 10^{-5}}{\mu_{a r, u}}
$$

Em que:

$\mu_{r} \quad$ : viscosidade dinâmica do ar seco (condições referência) (Pa.s);

$\mu_{a r, u} \quad$ : viscosidade dinâmica do ar úmido (Pa.s).

A viscosidade dinâmica do ar úmido é calculada pela eq. (B.2) [31]:

$$
\mu_{a r, u}=\frac{\mu_{w}}{1+\frac{Y_{a r, s}}{Y_{W}} \frac{\left[1+\left(\frac{\mu_{W}}{\mu_{a r, s}}\right)^{1 / 2}\left(\frac{M_{W}}{M_{a r, s}}\right)^{1 / 4}\right]^{2}}{2,83\left[1+\frac{M_{W}}{M_{a r, s}}\right]^{1 / 2}}}+\frac{\mu_{a r, s}}{1+\frac{Y_{W}}{Y_{a r, s}} \frac{\left[1+\left(\frac{\mu_{a r, s}}{\mu_{W}}\right)^{1 / 2}\left(\frac{M_{a r}, s}{M_{W}}\right)^{1 / 4}\right]^{2}}{2,83\left[1+\frac{M_{a r}, s}{M_{W}}\right]^{1 / 2}}}
$$

Em que:

$\mu_{w} \quad$ : viscosidade dinâmica do vapor d'água (Pa.s);

$\mu_{a r, s} \quad$ : viscosidade dinâmica do ar seco (Pa.s);

$Y_{w} \quad$ : fração molar da água (-);

$Y_{a r, s} \quad$ : fração molar do ar seco (-);

$M_{w} \quad$ : massa molar de água $(\mathrm{g} / \mathrm{mol})$;

$M_{a r, s} \quad$ : massa molar de ar seco $(\mathrm{g} / \mathrm{mol})$.

A viscosidade dinâmica do vapor d'água pode ser calculada pela relação da eq. (B.3) [126]:

$$
\mu_{w}=A e^{\frac{B}{\left(T_{a m b}-C\right)}}
$$

Em que:
A : $2,414 \times 10^{-5}$ (constante em Ns/m²);
B : 247,8 (constante em K);
$T_{\text {amb }} \quad$ : temperatura do ar atmosférico $(\mathrm{K})$; 
C $\quad: 140$ (constante em K).

Enquanto isso, para o cálculo da viscosidade dinâmica do ar seco emprega-se a correlação empírica de Sutherland da eq. (B.4) [126]:

$$
\mu_{a r, s}=\frac{b_{a r, s} T_{a m b}{ }^{3 / 2}}{s_{a r, s}+T_{a m b}}
$$

Em que:

$b_{a r, s} \quad: 1,458 \times 10^{-6}$ (constante em kg/m.s. $\mathrm{K}^{1 / 2}$ );

$s_{a r, s}: 110,4$ (constante em K).

A fração molar do ar seco pode ser calculada pela eq. (B.5):

$$
Y_{a r, s}=\frac{\omega M_{a r, s}}{M_{w}+\left(\omega M_{a r, s}\right)}=\frac{p_{a r, s}}{p_{a r, u}}
$$

Em que:

$\omega \quad$ : umidade absoluta (-);

$M_{w} \quad$ : massa molar de água $(\mathrm{g} / \mathrm{mol})$;

$M_{a r, s} \quad$ : massa molar de ar seco $(\mathrm{g} / \mathrm{mol})$;

$p_{a r, s} \quad$ : pressão de ar seco $(\mathrm{kPa})$.

Logo, a fração molar de vapor d'água é estabelecida pela eq. (B.6):

$$
Y_{w}=1-Y_{a r, s}
$$

As expressões para a determinação dos fatores de correção para a temperatura e pressão são, respectivamente, eq. (B.7) e eq. (B.8):

$$
\begin{aligned}
\left(\frac{T_{r}}{T_{a r, u}}\right) & =\frac{298,15}{T_{a r, u}} \\
\left(\frac{p_{a r, u}}{p_{r}}\right) & =\frac{p_{a r, u}}{101,325}
\end{aligned}
$$

Em que:

$T_{r} \quad$ : temperatura do ar na condição de referência $(\mathrm{K})$;

$p_{r} \quad$ : pressão do ar na condição de referência $(\mathrm{kPa})$;

$T_{a r, u} \quad$ : temperatura de ar úmido medida nos ensaios $(\mathrm{K})$;

$p_{a r, u} \quad$ : pressão de ar úmido medida nos ensaios $(\mathrm{kPa})$.

Por último, o fator de correção da massa específica está explicitado pela eq. (B.9): 


$$
\left(\frac{\rho_{a r, u}}{\rho_{r}}\right)=\frac{\rho_{a r, u}}{1,19}
$$

Em que:

$\rho_{a r, u} \quad$ : massa específica do ar úmido $\left(\mathrm{kg} / \mathrm{m}^{3}\right)$;

$\rho_{r} \quad$ : massa específica do ar seco (condições referência) $\left(\mathrm{kg} / \mathrm{m}^{3}\right)$.

Para o cálculo da massa específica do ar úmido, tem-se a eq. (B.10):

$$
\rho_{a r, u}=\frac{p_{a r, u}}{R_{a r, u} T_{a r, u}}
$$

Em que:

$R_{a r, u} \quad$ : constante do ar úmido $(\mathrm{kJ} / \mathrm{kgK})$.

Tipicamente, a constante $\mathrm{R}$ é dada para a condição de ar seco, porém esta constante pode ser corrigida para a condição de ar úmido através da eq. (B.11):

$$
R_{a r, u}=\frac{R_{a r, s}+R_{w} \omega}{1+\omega}
$$

Em que:

$R_{a r, s} \quad:$ constante do ar seco $(\mathrm{kJ} / \mathrm{kgK})$;

$R_{w} \quad$ : constante do vapor d'água $(\mathrm{kJ} / \mathrm{kgK})$.

A umidade absoluta para uma mistura composta por ar e vapor d'água é um parâmetro estimado em função da umidade relativa, pressão de saturação e pressão do ar úmido ambiente, conforme a eq. (B.12) [122]:

$$
\omega=\frac{0,622 U_{r} p_{s a t}}{p_{a r, u}-\left(U_{r} p_{s a t}\right)}
$$

Em que:

$U_{r} \quad$ : umidade relativa (-);

$p_{\text {sat }} \quad$ : pressão de saturação $(\mathrm{kPa})$.

A pressão de saturação é dada em função da temperatura do ar úmido $\left(T_{a r, u}\right)$, de acordo com a expressão indicada na eq. (B.13) [127]:

$$
p_{\text {sat }}=10^{\left(30,59-8,2 \log \left(T_{a r, u}\right)+0,0024804 T_{a r, u}-\frac{3142,31}{T_{a r}, u}\right)}
$$


C.

\section{Análise de Incertezas}

C.1

Incertezas nas Medições

A incerteza de medição é um parâmetro que está associado ao resultado de uma medição e caracteriza a dispersão de valores razoáveis para a atribuição do mensurando. Segundo o Guia para Expressão de Incerteza de Medição do INMETRO [123], a incerteza de medição possui alguns componentes agrupáveis em duas categorias de avaliação, de acordo com a origem destes: incerteza do Tipo $A\left(I_{A}\right)$ e incerteza do Tipo $B\left(I_{B}\right)$.

A incerteza do Tipo A é uma incerteza padrão que reúne componentes relacionados à repetitividade de resultados de série de medições executadas sob mesmas condições experimentais. O método de avaliação do Tipo A configurase pela análise estatística de séries de dados. De Melo [124] menciona em sua tese que a incerteza Tipo A pode ser calculada dividindo-se o desvio padrão pela raiz quadrada do número de pontos medidos, quando há uma quantidade razoável de dados.

Já a incerteza do Tipo B, diz respeito aos métodos de avaliação de incerteza alheios a análises estatísticas de séries de dados. O Tipo B refere-se a incertezas atribuídas a resoluções, certificados ou curvas de calibração de equipamentos, bem como padrões utilizados. Portanto, a incerteza Tipo B consiste em uma combinação de diversos fatores, em que $S_{1}, S_{2}$ e $S_{i}$ representam as diferentes componentes de incerteza deste Tipo $\left(\mathrm{I}_{\mathrm{B}}\right)$ na eq. (C.1):

$$
I_{B}=\sqrt{S_{1}^{2}+S_{2}^{2}+\cdots+S_{i}^{2}}
$$

De maneira similar, a obtenção da incerteza combinada $\left(\mathrm{I}_{\mathrm{C}}\right)$ é dada pela combinação entre as incertezas do Tipo A e Tipo B, conforme a eq. (C.2):

$$
I_{C}=\sqrt{I_{A}^{2}+I_{B}^{2}}
$$

Por último há a incerteza expandida $\left(\mathrm{I}_{\mathrm{E}}\right)$ que define um intervalo em torno do resultado de uma medição em que se abrange grande parte da distribuição de valores que possam ser atribuídos ao mensurando. A relevância desta parcela de distribuição dos valores pode ser traduzida como a probabilidade de abrangência ou nível de confiança do intervalo, estimado pelo fator de 
abrangência. Este fator é um multiplicador da incerteza padrão combinada utilizado na obtenção da incerteza expandida. Para os casos analisados nesta dissertação, em que houve números significativos de medições, é possível aproximar a 2 (dois) o fator de abrangência para um grau de confiança de 95\%, conforme sugerido pela tese de De Melo [124].

Listam-se, logo abaixo, as resoluções, valores de calibrações e valores indicados em folhas de dados sobre erros e incertezas, seguidos das respectivas incertezas padrão dos equipamentos utilizados nas medições dos ensaios ao longo do desenvolvimento da dissertação.

\begin{tabular}{c|cc}
\hline Grandeza & Valor & Incerteza Padrão \\
\hline Vazão Volumétrica & $\pm 0,317 \%$ & $\pm 0,183 \%$ \\
Umidade Relativa & $\pm 2,0 \%$ & $\pm 1,15 \%$ \\
Temperatura & $\pm 0,7 \mathrm{~K}$ & $\pm 0,4 \mathrm{~K}$ \\
Pressão Ambiente (Atmosférica) & $\pm 0,108 \mathrm{kPa}$ & $\pm 0,063 \mathrm{kPa}$ \\
Vazão de Combustível & $\pm 0,05 \%$ & $\pm 0,029 \%$ \\
Torque & $\pm 1,2 \mathrm{Nm}$ & $\pm 0,693 \mathrm{Nm}$ \\
Rotação & $\pm 1,0 \mathrm{RPM}$ & $\pm 0,58 \mathrm{RPM}$ \\
Pressão no Interior do Cilindro & $\pm 0,6 \mathrm{bar}$ & $\pm 0,35 \mathrm{bar}$ \\
Início da Ignição & - & $\pm 0,5 \circ$ \\
\hline
\end{tabular}

Ao longo deste trabalho foram tomadas inúmeras precauções durante os procedimentos de aquisição dos dados para que se garantissem boas repetitividades nos resultados, assim como metodologias de testes que utilizassem coletas apropriadas do número de amostras, favorecendo a minimização de incertezas do Tipo A. É importante que esta preocupação na amenização de incertezas do Tipo A seja mencionada, já que os valores deste Tipo de incerteza são funções diretas dos procedimentos adotados nos ensaios, diferentemente das incertezas do Tipo $B$ que permanecem fixas ao longo dos testes e só variam com a diversificação de instrumentos disponíveis para a aquisição dos dados (circunstância que não ocorreu no transcorrer dos testes).

\section{C.2 \\ Propagação das Incertezas}

É comum deparar-se com situações nas quais a obtenção de um resultado não é possível pela medição direta, mas por outro lado a estimativa deste é viável através de modelagens matemáticas ou relações entre variáveis independentes que possam ser mensuradas. Para estes casos, é preciso avaliar 
como se dá a propagação das incertezas (do Tipo B) dos valores auferidos no resultado final.

Portanto, um resultado $R$ função de $N$ variáveis independentes, pode ter sua incerteza expressa a partir das incertezas das variáveis que o compõe através da eq. (C.3), segundo o método de Kline e McClintock apresentado por Moffat [125]:

$$
\delta R=\left\{\sum_{i=1}^{N}\left(\frac{\partial R}{\partial X_{i}} \delta X_{i}\right)^{2}\right\}^{1 / 2}
$$

Em que:

$R \quad$ : função composta por $\mathrm{N}$ variáveis independentes;

$\delta R \quad$ : incerteza de $\mathrm{R}$;

$X_{i} \quad$ : cada uma das $\mathrm{N}$ variáveis independentes;

$\delta X_{i} \quad$ : incerteza das variáveis $X_{i}$.

A seguir apresenta-se a estimativa de incerteza da eficiência térmica do etanol em uma mistura $\left(\eta_{t E-D B E}\right)$ para a exemplificação do método de propagação de incertezas.

Conforme apresentado na eq. (15), a eficiência térmica do etanol em uma mistura $\left(\eta_{t E-D B E}\right)$ relaciona potência efetiva fornecida pela mistura $\left(P_{b}\right)$, eficiência térmica com o combustível B15E0 $\left(\eta_{t B 15 E 0}\right)$, vazões mássicas de etanol $\left(\dot{m}_{c E}\right)$ e de B15E0 ( $\left.\dot{m}_{C B 15 E 0}\right)$ e poder calorífico dos combustíveis. Então, desprezando-se a incerteza dos PCi (estabelecidos conforme valores disponíveis na literatura), tem-se as derivadas parciais dos demais termos da eq. (15):

$$
\begin{gathered}
\frac{\partial \eta_{t E-D B E}}{\partial P_{b}}=\frac{3,6}{\dot{m}_{c E} P C i_{E}} \quad \frac{\partial \eta_{t E-D B E}}{\partial \dot{m}_{c}}=-\frac{3,6 P_{b}}{\dot{m}_{c E} \dot{m}_{C B 15 E 0} P C i_{E}} \\
\frac{\partial \eta_{t E-D B E}}{\partial \eta_{t B 15 E 0}}=\frac{\dot{m}_{c B 15 E 0} P C i_{B 15 E 0}}{\dot{m}_{C E} P C i_{E}}
\end{gathered}
$$

Portanto, a expressão final da incerteza da eficiência térmica do etanol em uma mistura é dada pela eq. (C.4):

$$
\delta \eta_{t}=\sqrt{\left(\frac{\partial \eta_{t E-D B E}}{\partial \dot{m}_{c}} \delta \dot{m}_{c}\right)^{2}+\left(\frac{\partial \eta_{t E-D B E}}{\partial P_{b}} \delta P_{b}\right)^{2}+\left(\frac{\partial \eta_{t E-D B E}}{\partial \eta_{t B 15 E 0}} \delta \eta_{t B 15 E 0}\right)^{2}}
$$


Anexos

A.

Correlação entre o Came e Deslocamento do Pistão Distribuidor

\begin{tabular}{|c|c|c|c|c|c|}
\hline so $\frac{8}{2}$ & $\frac{M a d}{A m}=a$ & & & - & \\
\hline 0.0 .00 & 0.0000 & 7.30 .00 & 1.2209 & 15. 0.00 & 2.4599 \\
\hline o. 7.50 & 0.0004 & 7.37 .50 & 1.2458 & 15. 7.50 & 2.4761 \\
\hline 0.15 .00 & 0.0018 & 7.45 .00 & 1.2706 & 15.15 .00 & $2.4922^{\circ}$ \\
\hline 0.22 .50 & 0.0040 & 7.52 .50 & 1.2952 & 15.22 .50 & 2.5002 \\
\hline 0.30 .00 & 0.0071 & 8. 0.00 & 1.3197 & 15.30 .00 & 2.5240 \\
\hline 0.37 .50 & 0.0110 & 8. 7.50 & 1.3440 & 15.37 .50 & 2.5396 \\
\hline 0.45 .00 & 0.0159 & e. 15.00 & 1.3682 & 15.45 .00 & 2.5551 \\
\hline 0.52 .50 & 0.0216 & e. 22.50 & 1.3923 & 15.52 .50 & 2.5705 \\
\hline 1.0 .00 & 0.0282 & 8.30 .00 & 1.4162 & 16. 0.00 & 2.5057 \\
\hline 1.7 .50 & 0.0357 & 8.37 .50 & 1.4392 & 16. 7.50 & 2.6000 \\
\hline 1.15 .00 & 0.0441 & 8.45 .00 & 1.4635 & 16.15 .00 & 2.6158 \\
\hline 1.22 .50 & 0.0534 & 8.52 .50 & 1.4870 & 16.22 .50 & 2.6306 \\
\hline 1.30 .00 & 0.0636 & 9. 0.00 & 1.5103 & 16.30 .00 & 2.6452 \\
\hline 1.37 .50 & 0.0747 & 9. 7.50 & 1.5335 & 16.37 .50 & 2.6597 \\
\hline 1.45 .00 & 0.0866 & 9.15 .00 & 1.5565 & 16.45 .00 & 2.6741 \\
\hline 1.52 .50 & 0.0995 & 9.22 .50 & 1.5794 & 16.52 .50 & 2.6883 \\
\hline 2. 0.00 & 0.1133 & 9.30 .00 & 1.6022 & 17. 0.00 & 2.7024 \\
\hline 2. 7.50 & 0.1281 & 9.37 .50 & 1.6248 & 17. 7.50 & 2.7163 \\
\hline 2.15 .00 & 0.1437 & 9.45 .00 & 1.6472 & 17.15 .00 & 2.7301 \\
\hline 2.22 .50 & 0.1603 & 9.52 .50 & 1.6595 & 17.22 .50 & 2.7437 \\
\hline 2.30 .00 & 0.1778 & 10.0 .00 & 1.5917 & 17.30 .00 & 2.7572 \\
\hline 2.37 .50 & 0.1963 & 10.7 .50 & 1.7137 & 17.37 .50 & 2.7704 \\
\hline 2.45 .00 & 0.2157 & 10.15 .00 & 1.7356 & 17.45 .00 & 2.7835 \\
\hline 2.52 .50 & 0.2361 & 10.22 .50 & 1.7573 & 17.52 .50 & 2.7965 \\
\hline 3. 0.00 & 0.2575 & 10.30 .00 & 1.7789 & 18.0 .00 & 2.8092 \\
\hline 3. 7.50 & 0.2799 & 10.37 .50 & 1.8004 & 18.7 .50 & 2.8217 \\
\hline 3.15 .00 & 0.3032 & 10.45 .00 & 1.8217 & 18.15 .00 & 2.8340 \\
\hline 3.22 .50 & 0.3276 & 10.52 .50 & 1.8428 & 18.22 .50 & 2.8462 \\
\hline $\mathbf{3 . 3 0 . 0 0}$ & 0.3530 & 11.0 .00 & 1.6638 & 18.30 .00 & 2. 8581 \\
\hline 3.37 .50 & 0.3795 & 11.7 .50 & 1.8847 & 18.37 .50 & 2.8698 \\
\hline 3.45 .00 & 0.4070 & 11.15 .00 & 1.9054 & 18.45 .00 & 2.8813 \\
\hline 3.52 .50 & 0.4355 & 11.22 .50 & 1.9250 & 18.52 .50 & 2.8927 \\
\hline 4. 0.00 & 0.4646 & 11.30 .00 & 1.9464 & 19. 0.00 & 2.9038 \\
\hline 4. 7.50 & 0.4936 & 11.37 .50 & 1.9867 & 19. 7.50 & 2.9147 \\
\hline 4.15 .00 & 0.5224 & 11.45 .00 & 1.9869 & 19.15 .00 & 2.9254 \\
\hline 4.22 .50 & 0.5511 & 11.52 .50 & 2.0059 & 19.22 .50 & 2.9359 \\
\hline 4.30 .00 & 0.5796 & 12. 0.00 & 2.0267 & 19.30 .00 & 2.9462 \\
\hline 4.37 .50 & 0.6080 & 12.7 .50 & 2.0464 & 19.37 .50 & 2.9563 \\
\hline 4.45 .00 & 0.6362 & 12.15 .00 & 2.0660 & 19.45 .00 & 2.9662 \\
\hline 4.52 .50 & 0.5543 & 12.22 .50 & 2.0854 & 19.52 .50 & 2.9759 \\
\hline 5. 0.00 & 0.6923 & 12.30 .00 & 2.1047 & 20.0 .00 & 2.9854 \\
\hline 5. 7.50 & 0.7201 & 12.37 .50 & 2.1238 & 20.7 .50 & 2.9947 \\
\hline 5.15 .00 & 0.7477 & 12.45 .00 & 2.1120 & 20.15 .00 & 3.0030 \\
\hline 5.22 .50 & 0.7753 & 12.52 .50 & 2.1616 & 20.22 .50 & 3.0126 \\
\hline 5.30 .00 & 0.8026 & 13.0 .00 & 2.1803 & 20.30 .00 & 3.0213 \\
\hline 5.37 .50 & 0.8299 & 13.7 .50 & 2.1989 & 20.37 .50 & 3.0298 \\
\hline 5.45 .00 & 0.8569 & 13.15 .00 & 2.2173 & 20.45 .00 & 3.0380 \\
\hline 5.52 .50 & 0.8839 & 13.22 .50 & 2.2356 & 20.52 .50 & 3.0461 \\
\hline 6. 0.00 & 0.9107 & 13.30 .00 & 2.2537 & 21.0 .00 & 3.0530 \\
\hline 6. 7.50 & 0.9373 & 13.37 .50 & 2.2717 & 21.7 .50 & 3.0615 \\
\hline 6.15 .00 & 0.9638 & 13.45 .00 & 2.2895 & 21.15 .00 & 3.0689 \\
\hline 6.22 .50 & 0.9902 & 13.52 .50 & 2.3072 & 21.22 .50 & 3.0762 \\
\hline 6.30 .00 & 1.0164 & 14.0 .00 & 2.3247 & 21.30 .00 & 3.0832 \\
\hline 6.37 .50 & 1.0425 & 14. 7.50 & 2.3421 & $21.37+50$ & 3.0000 \\
\hline 6.45 .00 & 1.0684 & 14.15 .00 & 2.3584 & 21.45 .00 & $\mathbf{3 . 0 9 6 6}$ \\
\hline 6.52 .50 & 1.0942 & 14.22 .50 & 2.3765 & 21.52 .50 & 3.1029 \\
\hline 7. 0.00 & 1.1198 & 14.30 .00 & 2.3935 & 22. 0.00 & 3.1091 \\
\hline 7.50 & 1.1453 & 14.37 .50 & 2.4103 & 22. $7+50$ & 3.1151 \\
\hline 7.15 .00 & 1.1705 & 14.45 .00 & 2.4269 & 22.15 .00 & 3.1208 \\
\hline 7.22. & 1.1958 & 14.52 .50 & 2.4435 & 22.22 .50 & 3.1264 \\
\hline
\end{tabular}


B.

Caracterização da Amostra de Diesel Comercial (B7)

\begin{tabular}{c|cc}
\hline Propriedades & Método & Diesel Comercial \\
\hline Massa Específica & NBR 14065 & $833,8 \mathrm{~kg} / \mathrm{m}^{3}$ \\
Aspecto & Visual & Límpido \\
Cor ASTM & ASTM D1500 & 1,5 \\
Teor de Biodiesel & EN 14078 & $7,4 \% \mathrm{v} / \mathrm{v}$ \\
Teor de Enxofre & ASTM D5453 & $4,07 \mathrm{mg} / \mathrm{kg}$ \\
Ponto de Fulgor Pensky Martens & ASTM D93 & $65^{\circ} \mathrm{C}$ \\
Ponto de Entupimento de Filtro à Frio & ASTM D6371 & $-6^{\circ} \mathrm{C}$ \\
Índice de Cetano Calculado & ASTM D4737 & 55,4 \\
Resíduo de Carbono Ramsbottom 10\% finais & ASTM D524 & 0,06 \\
Cinzas & ASTM D481 & 0,003 \\
Corrosividade ao Cobre & ASTM D130 & $1 \mathrm{a}$ \\
Teor de Água por Karl Fisher & ASTM D6304 & $88,7 \mathrm{mg} / \mathrm{kg}$ \\
\hline
\end{tabular}

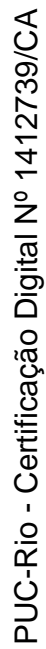


C.

Caracterização da Amostra de Biodiesel Puro

\begin{tabular}{|c|c|c|}
\hline Propriedades & Método & Biodiesel B100 \\
\hline Massa Específica & NBR 14065 & $877,1 \mathrm{~kg} / \mathrm{m}^{3}$ \\
\hline Aspecto & NBR 16048 & Límpido \\
\hline Viscosidade Cinemática $\left(@ 40^{\circ} \mathrm{C}\right)$ & ASTM D445 & $4,44 \mathrm{~mm}^{2} / \mathrm{s}$ \\
\hline Teor de Água & ASTM D6304 & $164 \mathrm{mg} / \mathrm{kg}$ \\
\hline Contaminação Total & EN 12662 & $21,0 \mathrm{mg} / \mathrm{kg}$ \\
\hline Ponto de Fulgor & NBR 14598 & $132^{\circ} \mathrm{C}$ \\
\hline Teor de Éster (em massa) & EN 14103 & $98,3 \%$ \\
\hline Teor de Enxofre & ASTM D5453 & $4,1 \mathrm{mg} / \mathrm{kg}$ \\
\hline Teor de Sódio+Potássio & NBR 15556 & $<0,7 \mathrm{mg} / \mathrm{kg}$ \\
\hline Teor de Cálcio+Magnésio & NBR 15553 & $<2,0 \mathrm{mg} / \mathrm{kg}$ \\
\hline Teor de Fósforo & NBR 15553 & $<1,0 \mathrm{mg} / \mathrm{kg}$ \\
\hline Ponto de Entupimento & NBR 14747 & $8^{\circ} \mathrm{C}$ \\
\hline Índice de Acidez Total & ASTM D664 & $0,25 \mathrm{mg} \mathrm{KOH} / \mathrm{g}$ \\
\hline Glicerina Livre (em massa) & ASTM D6584 & $0,014 \%$ \\
\hline Glicerina Total (em massa) & ASTM D6584 & $0,195 \%$ \\
\hline Teor de Monoglicerídeos (em massa) & ASTM D6584 & $0,548 \%$ \\
\hline Teor de Diglicerídeos (em massa) & ASTM D6584 & $0,167 \%$ \\
\hline Teor de Triglicerídeos (em massa) & ASTM D6584 & $0,135 \%$ \\
\hline Índice de lodo & EN 14111 & $93 \mathrm{~g}$ de $\mathrm{lodo} / 100 \mathrm{~g}$ \\
\hline Estabilidade de Oxidação (@110C) & EN 14112 & $9,3 \mathrm{~h}$ \\
\hline
\end{tabular}


D.

Tabelas de Testes com Avanço de Injeção Fixo em 10,5 BTDC

\begin{tabular}{|c|c|c|c|c|c|c|c|c|c|c|c|c|c|c|c|c|c|c|c|c|c|}
\hline \multicolumn{22}{|c|}{ AVANÇO $10,5^{\circ}$} \\
\hline 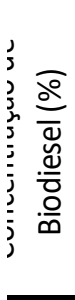 & 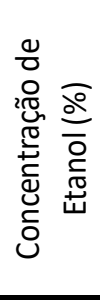 & 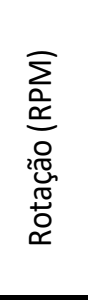 & 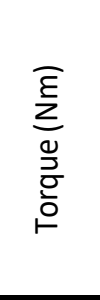 & 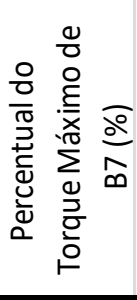 & $\begin{array}{l}\frac{0}{2} \\
\frac{0}{0} \\
\frac{0}{0} \\
\frac{0}{0} \\
\frac{0}{4}\end{array}$ & 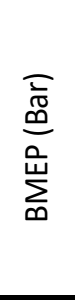 & 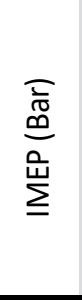 & 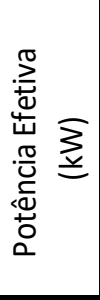 & 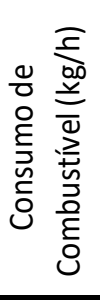 & 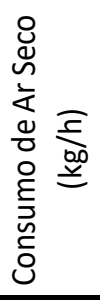 & 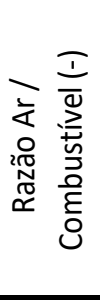 & $\begin{array}{l}I \\
I \\
\frac{\pi}{0} \\
\frac{0}{E} \\
\frac{1}{J}\end{array}$ & 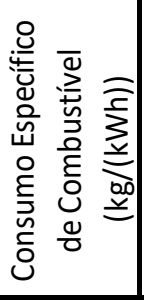 & 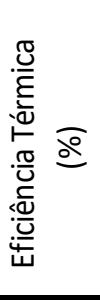 & 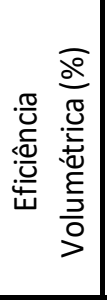 & 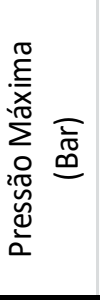 & 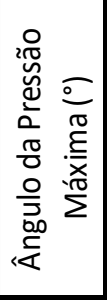 & 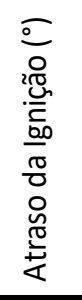 & 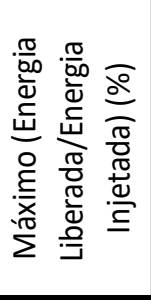 & 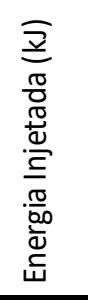 & 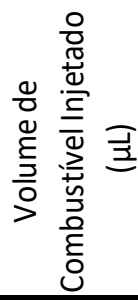 \\
\hline \multirow{9}{*}{7} & \multirow{9}{*}{0} & 1501 & 81,2 & 25,0 & 46,6 & 2,4 & 4,2 & 12,8 & 3,7 & 204,9 & 55,5 & 3,85 & 0,2895 & 27,6 & 94,2 & 67,4 & 5,0 & 14,0 & 85,43 & 1,85 & 48,94 \\
\hline & & 1502 & 161,9 & 50,0 & 56,9 & 4,7 & 6,9 & 25,5 & 6,1 & 221,1 & 36,5 & 2,53 & 0,2378 & 33,5 & 101,7 & 74,5 & 9,3 & 14,0 & 82,91 & 3,05 & 80,63 \\
\hline & & 1503 & 327,2 & 100,0 & 100,0 & 9,6 & 12,7 & 51,5 & 11,5 & 272,0 & 23,7 & 1,64 & 0,2232 & 35,7 & 124,2 & 98,5 & 13,0 & 12,0 & 81,41 & 5,75 & 151,91 \\
\hline & & 1804 & 96,5 & 25,0 & 54,6 & 2,8 & 5,3 & 18,2 & 5,2 & 257,8 & 49,8 & 3,45 & 0,2842 & 28,1 & 98,4 & 77,0 & 7,0 & 11,0 & 90,53 & 2,17 & 57,23 \\
\hline & & 1791 & 193,4 & 50,0 & 67,8 & 5,6 & 8,4 & 36,4 & 8,6 & 295,3 & 34,3 & 2,38 & 0,2368 & 33,7 & 113,2 & 90,1 & 9,0 & 10,7 & 86,02 & 3,61 & 95,33 \\
\hline & & 1801 & 387,7 & 100,0 & 100,0 & 11,3 & 15,3 & 73,1 & 16,2 & 379,7 & 23,4 & 1,62 & 0,2216 & 36,0 & 145,8 & 121,5 & 13,0 & 8,3 & 87,10 & 6,76 & 178,58 \\
\hline & & 2098 & 90,0 & 25,0 & 66,6 & 2,6 & 5,4 & 19,8 & 6,2 & 303,4 & 49,3 & 3,42 & 0,3114 & 25,6 & 100,1 & 82,8 & 6,0 & 9,0 & 96,55 & 2,22 & 58,67 \\
\hline & & 2100 & 180,3 & 50,0 & 78,6 & 5,3 & 8,5 & 39,6 & 9,9 & 351,5 & 35,6 & 2,47 & 0,2488 & 32,1 & 116,0 & 100,1 & 9,0 & 9,3 & 92,64 & 3,55 & 93,59 \\
\hline & & 2097 & 359,1 & 100,0 & 100,0 & 10,5 & 14,6 & 78,9 & 18,0 & 428,5 & 23,8 & 1,65 & 0,2278 & 35,0 & 142,4 & 130,3 & 10,0 & 5,7 & 87,64 & 6,46 & 170,42 \\
\hline \multirow{9}{*}{15} & \multirow{9}{*}{0} & 1502 & 82,1 & 25,0 & 46,5 & 2,4 & 4,3 & 12,9 & 3,7 & 198,6 & 53,0 & 3,72 & 0,2902 & 28,0 & 91,9 & 66,5 & 5,0 & 13,7 & 87,99 & 1,82 & 48,66 \\
\hline & & 1506 & 163,5 & 50,0 & 57,0 & 4,8 & 6,9 & 25,8 & 6,2 & 217,3 & 35,3 & 2,48 & 0,2388 & 34,0 & 100,5 & 74,6 & 10,0 & 13,7 & 82,85 & 3,05 & 81,33 \\
\hline & & 1501 & 322,8 & 98,7 & 100,0 & 9,4 & 12,6 & 50,8 & 11,5 & 271,3 & 23,6 & 1,66 & 0,2267 & 35,8 & 123,7 & 100,0 & 13,0 & 13,3 & 82,03 & 5,67 & 151,35 \\
\hline & & 1796 & 97,2 & 25,0 & 54,6 & 2,8 & 5,3 & 18,3 & 5,4 & 250,8 & 46,7 & 3,28 & 0,2938 & 27,6 & 96,9 & 76,5 & 7,0 & 14,3 & 89,44 & 2,22 & 59,40 \\
\hline & & 1798 & 194,0 & 50,0 & 67,9 & 5,7 & 8,4 & 36,5 & 8,8 & 287,6 & 32,5 & 2,28 & 0,2420 & 33,5 & 111,0 & 89,8 & 10,0 & 9,7 & 88,51 & 3,62 & 96,69 \\
\hline & & 1801 & 377,9 & 97,5 & 100,0 & 11,0 & 14,8 & 71,3 & 16,1 & 378,0 & 23,5 & 1,65 & 0,2260 & 35,9 & 144,9 & 121,9 & 13,0 & 7,3 & 84,91 & 6,61 & 176,60 \\
\hline & & 2100 & 89,9 & 25,0 & 66,9 & 2,6 & 5,4 & 19,8 & 6,3 & 299,1 & 47,3 & 3,32 & 0,3199 & 25,4 & 99,3 & 83,1 & 6,0 & 8,0 & 96,38 & 2,22 & 59,26 \\
\hline & & 2098 & 180,7 & 50,0 & 78,6 & 5,3 & 8,4 & 39,7 & 10,2 & 346,2 & 34,0 & 2,39 & 0,2566 & 31,9 & 115,1 & 99,9 & 9,0 & 9,0 & 90,07 & 3,60 & 96,04 \\
\hline & & 2099 & 353,1 & 98,3 & 100,0 & 10,3 & 14,4 & 77,6 & 17,7 & 433,5 & 24,6 & 1,73 & 0,2280 & 35,7 & 143,6 & 130,9 & 10,0 & 6,0 & 88,29 & 6,24 & 166,58 \\
\hline \multirow{9}{*}{15} & \multirow{9}{*}{5} & 1506 & 81,7 & 25,0 & 49,6 & 2,4 & 4,3 & 12,9 & 3,8 & 188,8 & 49,3 & 3,52 & 0,2973 & 27,8 & 89,1 & 66,0 & 7,3 & 14,3 & 90,67 & 1,85 & 50,41 \\
\hline & & 1505 & 164,3 & 50,0 & 60,4 & 4,8 & 7,0 & 25,9 & 6,4 & 201,9 & 31,6 & 2,26 & 0,2465 & 33,5 & 95,6 & 73,0 & 9,0 & 14,0 & 85,64 & 3,08 & 84,03 \\
\hline & & 1507 & 249,1 & 76,1 & 100,0 & 7,3 & 10,2 & 39,3 & 9,1 & 227,8 & 25,0 & 1,78 & 0,2319 & 35,6 & 106,2 & 86,7 & 13,0 & 15,0 & 86,21 & 4,39 & 119,91 \\
\hline & & 1803 & 97,8 & 25,0 & 58,2 & 2,9 & 5,5 & 18,5 & 5,5 & 236,7 & 43,3 & 3,10 & 0,2958 & 27,9 & 93,2 & 75,2 & 5,0 & 14,0 & 92,99 & 2,20 & 60,01 \\
\hline & & 1795 & 193,9 & 50,0 & 71,5 & 5,7 & 8,7 & 36,5 & 9,0 & 267,1 & 29,6 & 2,11 & 0,2476 & 33,4 & 105,5 & 88,0 & 11,0 & 14,3 & 90,35 & 3,65 & 99,66 \\
\hline & & 1801 & 294,6 & 76,0 & 100,0 & 8,6 & 12,2 & 55,5 & 12,9 & 319,7 & 24,8 & 1,77 & 0,2325 & 35,6 & 125,4 & 105,7 & 13,0 & 14,0 & 86,21 & 5,19 & 141,66 \\
\hline & & 2098 & 89,0 & 25,0 & 69,4 & 2,6 & 5,7 & 19,6 & 6,2 & 280,7 & 44,9 & 3,21 & 0,3195 & 25,9 & 95,2 & 81,2 & 7,3 & 9,7 & 102,44 & 2,16 & 59,00 \\
\hline & & 2097 & 178,5 & 50,0 & 81,6 & 5,2 & 8,7 & 39,2 & 10,1 & 324,5 & 32,1 & 2,29 & 0,2575 & 32,1 & 110,3 & 98,2 & 10,0 & 9,0 & 93,64 & 3,50 & 95,52 \\
\hline & & 2101 & 290,9 & 81,0 & 100,0 & 8,5 & 12,6 & 64,0 & 15,3 & 391,2 & 25,6 & 1,83 & 0,2387 & 34,6 & 132,1 & 118,9 & 12,0 & 8,0 & 91,39 & 5,28 & 144,06 \\
\hline
\end{tabular}




\begin{tabular}{|c|c|c|c|c|c|c|c|c|c|c|c|c|c|c|c|c|c|c|c|c|c|}
\hline \multicolumn{22}{|c|}{ AVANÇO $10,5^{\circ}$} \\
\hline 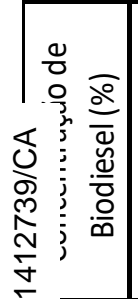 & 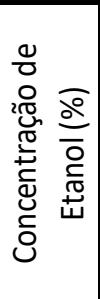 & 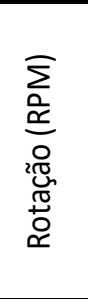 & 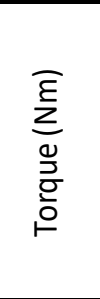 & 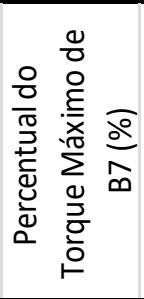 & $\begin{array}{l}\frac{\overline{0}}{1} \\
\frac{1}{0} \\
\frac{0}{0} \\
\frac{0}{0} \\
\frac{0}{4}\end{array}$ & $\begin{array}{l}\overline{\bar{I}} \\
\stackrel{9}{0} \\
\text { 岕 } \\
\sum_{0}\end{array}$ & 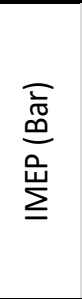 & 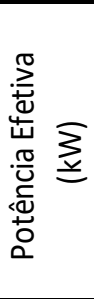 & 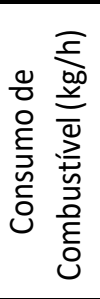 & 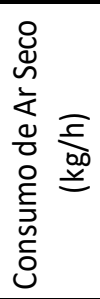 & 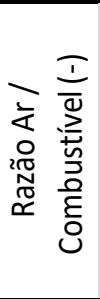 & $\begin{array}{l}I \\
I \\
\frac{\pi}{0} \\
0 \\
\frac{0}{E} \\
\frac{\pi}{J}\end{array}$ & 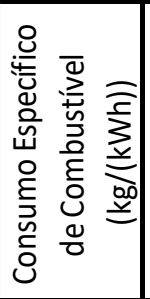 & 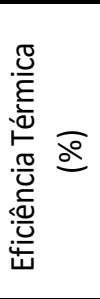 & 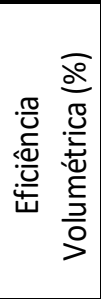 & 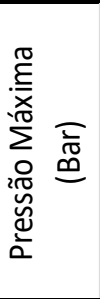 & 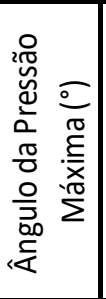 & 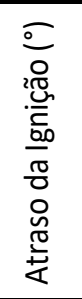 & 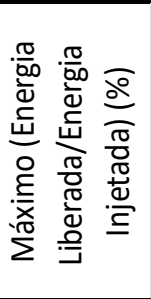 & 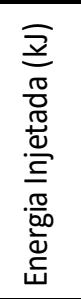 & 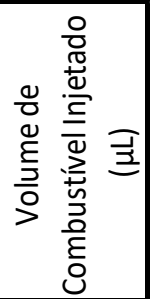 \\
\hline \multirow{9}{*}{15} & \multirow{9}{*}{10} & 1503 & 81,5 & 25,0 & 47,7 & 2,4 & 4,3 & 12,8 & 3,8 & 202,3 & 53,0 & 3,85 & 0,2976 & 28,3 & 93,8 & 65,4 & 8,3 & 14,7 & 90,71 & 1,80 & 50,26 \\
\hline & & 1504 & 164,8 & 50,0 & 58,2 & 4,8 & 7,0 & 25,9 & 6,5 & 217,1 & 33,4 & 2,43 & 0,2509 & 33,6 & 100,8 & 73,3 & 9,0 & 12,7 & 83,56 & 3,08 & 85,91 \\
\hline & & 1503 & 231,8 & 70,8 & 100,0 & 6,8 & 9,5 & 36,5 & 9,0 & 222,1 & 24,7 & 1,80 & 0,2457 & 34,1 & 104,1 & 81,1 & 14,0 & 13,3 & 81,97 & 4,27 & 119,03 \\
\hline & & 1798 & 96,6 & 25,0 & 55,5 & 2,8 & 5,3 & 18,2 & 5,4 & 248,7 & 46,0 & 3,34 & 0,2972 & 28,3 & 96,5 & 75,7 & 5,0 & 15,0 & 93,72 & 2,14 & 59,70 \\
\hline & & 1796 & 193,9 & 50,0 & 68,9 & 5,7 & 8,4 & 36,5 & 9,2 & 284,4 & 30,9 & 2,25 & 0,2527 & 33,3 & 110,2 & 88,0 & 11,0 & 10,7 & 89,10 & 3,63 & 101,38 \\
\hline & & 1794 & 250,9 & 64,7 & 100,0 & 7,3 & 10,1 & 46,9 & 11,8 & 296,7 & 25,2 & 1,83 & 0,2514 & 33,5 & 117 & 92,1 & 13,0 & 11,0 & 88,86 & 4,68 & 130,75 \\
\hline & & 2097 & 90,1 & 25,0 & 67,1 & 2,6 & 5,3 & 19,8 & 6,3 & 294,6 & 46,8 & 3,40 & 0,3178 & 26,5 & 98,3 & 82,5 & 7,0 & 9,0 & 98,20 & 2,14 & 59,72 \\
\hline & & 2097 & 178,8 & 50,0 & 79,1 & 5,2 & 8,5 & 39,3 & 10,1 & 340,4 & 33,6 & 2,44 & 0,2583 & 32,6 & 113,8 & 98,7 & 10,0 & 9,3 & 94,41 & 3,43 & 95,74 \\
\hline & & 2101 & 257,3 & 71,7 & 100,0 & 7,5 & 11,0 & 56,6 & 14,2 & 377,1 & 26,5 & 1,93 & 0,2510 & 33,5 & 127,5 & 105,3 & 11,0 & 7,0 & 87,97 & 4,81 & 134,35 \\
\hline \multirow{9}{*}{15} & \multirow{9}{*}{15} & 1508 & 81,8 & 25,0 & 49,7 & 2,4 & 4,3 & 12,9 & 4,0 & 203,5 & 50,6 & 3,75 & 0,3112 & 27,6 & 93,8 & 65,7 & 7,7 & 16,0 & 89,15 & 1,85 & 52,89 \\
\hline & & 1506 & 163,0 & 50,0 & 61,5 & 4,8 & 6,8 & 25,7 & 6,8 & 218,0 & 32,2 & 2,38 & 0,2633 & 32,6 & 100,5 & 72,2 & 9,0 & 17,3 & 78,85 & 3,15 & 90,04 \\
\hline & & 1502 & 230,5 & 70,4 & 100,0 & 6,7 & 9,3 & 36,2 & 9,0 & 241,1 & 26,8 & 1,98 & 0,2485 & 34,6 & 110,7 & 81,2 & 12,0 & 16,0 & 82,70 & 4,19 & 119,48 \\
\hline & & 1806 & 98,3 & 25,0 & 59,8 & 2,9 & 5,3 & 18,6 & 5,8 & 254,0 & 43,7 & 3,23 & 0,3129 & 27,5 & 97,5 & 75,4 & 6,0 & 14,0 & 89,34 & 2,24 & 64,04 \\
\hline & & 1794 & 193,3 & 50,0 & 73,0 & 5,6 & 8,6 & 36,3 & 9,5 & 290,4 & 30,6 & 2,27 & 0,2613 & 32,9 & 112,3 & 86,9 & 12,0 & 14,3 & 89,37 & 3,70 & 105,59 \\
\hline & & 1799 & 248,2 & 64,0 & 100,0 & 7,2 & 10,2 & 46,8 & 11,9 & 306,5 & 25,8 & 1,91 & 0,2538 & 33,9 & 119,5 & 93,0 & 13,0 & 14,3 & 85,38 & 4,62 & 131,90 \\
\hline & & 2097 & 89,5 & 25,0 & 69,5 & 2,6 & 5,4 & 19,6 & 6,6 & 299,5 & 45,6 & 3,38 & 0,3344 & 25,7 & 99,4 & 83,2 & 5,0 & 12,0 & 97,62 & 2,20 & 62,76 \\
\hline & & 2099 & 178,6 & 50,0 & 81,4 & 5,2 & 8,4 & 39,3 & 10,6 & 349,2 & 32,9 & 2,44 & 0,2700 & 31,8 & 115,9 & 96,2 & 11,0 & 9,7 & 94,08 & 3,53 & 100,70 \\
\hline & & 2100 & 246,7 & 68,7 & 100,0 & 7,2 & 10,5 & 54,3 & 14,0 & 381,3 & 27,2 & 2,01 & 0,2582 & 33,3 & 127,9 & 102,0 & 12,0 & 11,3 & 87,05 & 4,66 & 132,94 \\
\hline \multirow{9}{*}{15} & \multirow{9}{*}{20} & 1505 & 81,0 & 25,0 & 50,4 & 2,4 & 4,3 & 12,8 & 4,1 & 198,0 & 47,9 & 3,61 & 0,3241 & 27,0 & 91,9 & 65,0 & 9,0 & 17,7 & 89,70 & 1,86 & 54,49 \\
\hline & & 1505 & 163,1 & 50,0 & 62,0 & 4,8 & 6,8 & 25,7 & 7,0 & 214,6 & 30,8 & 2,32 & 0,2710 & 32,3 & 99,6 & 71,0 & 10,7 & 17,3 & 80,45 & 3,18 & 93,04 \\
\hline & & 1504 & 221,7 & 67,8 & 100,0 & 6,5 & 9,2 & 34,9 & 9,0 & 233,0 & 25,9 & 1,95 & 0,2580 & 34,0 & 107,3 & 78,7 & 13,3 & 15,7 & 83,81 & 4,10 & 119,70 \\
\hline & & 1800 & 97,1 & 25,0 & 59,4 & 2,8 & 5,2 & 18,3 & 5,8 & 245,3 & 42,2 & 3,18 & 0,3176 & 27,6 & 95,4 & 73,8 & 7,0 & 15,7 & 91,27 & 2,21 & 64,45 \\
\hline & & 1796 & 193,3 & 50,0 & 73,1 & 5,6 & 8,5 & 36,3 & 9,7 & 282,2 & 29,0 & 2,19 & 0,2674 & 32,8 & 109,9 & 84,8 & 10,0 & 15,0 & 88,25 & 3,70 & 108,03 \\
\hline & & 1799 & 226,8 & 58,5 & 100,0 & 6,6 & 9,6 & 42,7 & 11,1 & 304,9 & 27,5 & 2,07 & 0,2599 & 33,7 & 118,1 & 87,5 & 14,0 & 15,0 & 86,74 & 4,22 & 123,42 \\
\hline & & 2097 & 89,3 & 25,0 & 70,3 & 2,6 & 5,2 & 19,6 & 6,6 & 293,7 & 44,3 & 3,34 & 0,3385 & 25,9 & 98,3 & 80,1 & 6,0 & 13,0 & 96,23 & 2,15 & 62,96 \\
\hline & & 2098 & 179,0 & 50,0 & 82,6 & 5,2 & 8,4 & 39,3 & 10,8 & 342,9 & 31,6 & 2,38 & 0,2757 & 31,8 & 114,6 & 94,4 & 10,0 & 11,7 & 92,23 & 3,52 & 102,97 \\
\hline & & 2099 & 235,3 & 65,5 & 100,0 & 6,9 & 10,0 & 51,7 & 13,8 & 384,6 & 27,9 & 2,10 & 0,2667 & 32,9 & 128,1 & 98,2 & 13,0 & 12,7 & 87,86 & 4,50 & 131,51 \\
\hline
\end{tabular}


E.

Tabela de Testes da Investigação dos Avanços de Injeção

\begin{tabular}{|c|c|c|c|c|c|c|c|c|c|c|c|c|c|c|c|c|c|c|c|c|c|c|c|c|c|c|c|c|c|c|c|}
\hline \multicolumn{8}{|c|}{ MISTURA B15E5 } & \multicolumn{8}{|c|}{ MISTURA B15E10 } & \multicolumn{8}{|c|}{ MISTURA B15E15 } & \multicolumn{8}{|c|}{ MISTURA B15E20 } \\
\hline 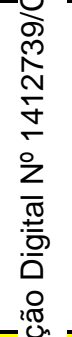 & $\begin{array}{l}\bar{\xi} \\
\underline{\underline{z}} \\
\frac{v}{\partial} \\
\overline{0} \\
\overline{0}\end{array}$ & 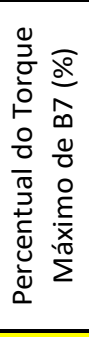 & $\begin{array}{l}\widehat{0} \\
\frac{0}{0} \\
\frac{0}{0} \\
\frac{0}{0} \\
\frac{0}{0} \\
\frac{0}{4}\end{array}$ & 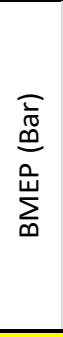 & 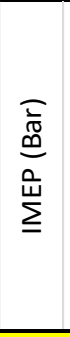 & 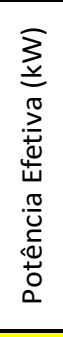 & 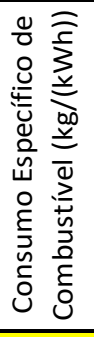 & 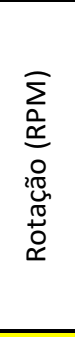 & $\begin{array}{l}\frac{\bar{\varepsilon}}{z} \\
\frac{0}{\partial} \\
\frac{0}{0} \\
\overline{0}\end{array}$ & 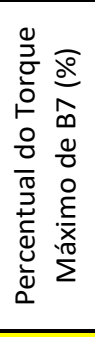 & $\begin{array}{l}\overline{0} \\
\frac{0}{0} \\
\frac{0}{0} \\
\frac{\pi}{0} \\
\frac{0}{0} \\
\frac{\dot{\alpha}}{4}\end{array}$ & 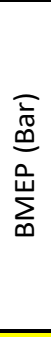 & 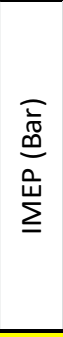 & 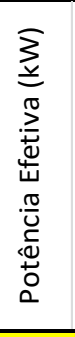 & 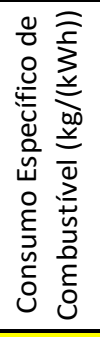 & 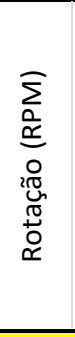 & 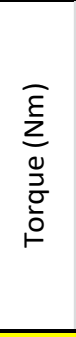 & 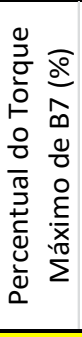 & $\begin{array}{l}\bar{\alpha} \\
\frac{0}{0} \\
\frac{0}{0} \\
\frac{\pi}{0} \\
\frac{0}{0} \\
\frac{4}{4}\end{array}$ & 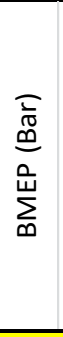 & 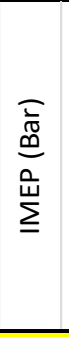 & 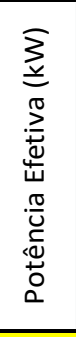 & 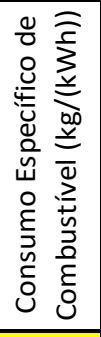 & 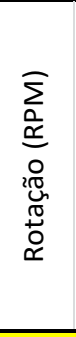 & $\begin{array}{l}\bar{\xi} \\
\underline{z} \\
\frac{0}{\partial} \\
\bar{\sigma} \\
\stackrel{0}{\circ}\end{array}$ & 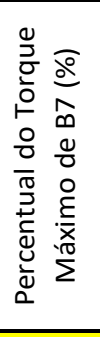 & 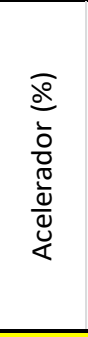 & 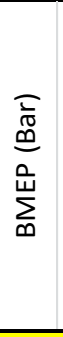 & 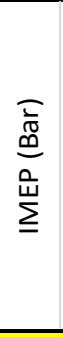 & 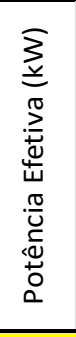 & 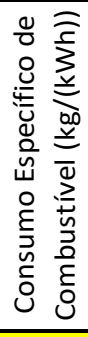 \\
\hline & 82,3 & 25,0 & 48,12 & 2,4 & 4,3 & 13,0 & 2958 & 1502 & 82,4 & 25,0 & 49,37 & 2,4 & 4,4 & 13,0 & 3073 & 04 & 81,1 & 25,0 & 49,67 & 2,4 & 4,2 & 12,8 & 0,3114 & 1503 & 82,1 & 25,0 & 50,18 & 2,4 & 4,3 & 12,9 & 3118 \\
\hline $1 \stackrel{0}{c}$ & 163,8 & 50,0 & 59,03 & 4,8 & 7,0 & 5,8 & 486 & 1505 & 163,6 & 50,0 & 60,09 & 4,8 & 6,9 & 5,8 & 5571 & 06 & 163,9 & 50,0 & 61,54 & 4,8 & 6,8 & 25,8 & 2612 & 1505 & 163,6 & 0,0 & 52,19 & 4,8 & 6,8 & 5,8 & 2611 \\
\hline & 274,1 & 83,8 & 100,00 & 8,0 & 10,9 & 43,2 & 2333 & 1495 & 234,4 & 71,6 & 100,00 & 6,8 & 9,6 & 36,7 & 2442 & 503 & 229,5 & 70,1 & 100,00 & 6,7 & 9,4 & 36,1 & 2437 & 1499 & 213,7 & 65,3 & $.00,00$ & 6,2 & 8,8 & 33,5 & 2491 \\
\hline $1 \cdot \frac{0}{\sim}$ & 96,5 & 25,0 & 56,15 & 2,8 & 5,4 & 18,1 & 3004 & 1802 & 97,2 & 25,0 & 57,29 & 2,8 & 5,4 & 18,3 & 0,3028 & 798 & 96,4 & 25,0 & 57,92 & 2,8 & 5,2 & 18,2 & 3107 & 1794 & 96,9 & 25,0 & 57,99 & 2,8 & 5,2 & 18,2 & ,3079 \\
\hline 10 & 194,6 & 50,0 & 70,42 & 5,7 & 8,7 & 36,7 & 2492 & 1795 & 192,9 & 50,0 & 70,55 & 5,6 & 8,5 & 36,3 & ,2545 & 304 & 194,6 & 50,0 & 75,05 & 5,7 & 8,7 & 36,8 & 2576 & 1796 & 194,0 & 0,0 & 3,16 & 5,7 & 8,6 & 36,5 & ,2569 \\
\hline $1 \vec{\alpha}$ & 328,6 & 84,8 & 100,00 & 9,6 & 13,7 & 62,0 & 0,2321 & 1799 & 265,8 & 68,6 & 100,00 & 7,8 & 10,7 & 50,1 & 0,2424 & 797 & 231,1 & 59,6 & 100,00 & 6,7 & 9,9 & 43,5 & 2477 & 1797 & 219,3 & 56,6 & 100,00 & 6,4 & 9,5 & 41,3 & , 2527 \\
\hline 2000 & 90,0 & $25, \mathrm{C}$ & 45 & 2,6 & 5,7 & 19,8 & 219 & 2098 & 90,3 & 25,0 & 45 & 2,6 & 5,3 & 19,8 & 3271 & 98 & 89,2 & 25,0 & 69,70 & 2,6 & 5,3 & 6 & 3372 & 2099 & 85 & 5,0 & & 2,6 & 5,2 & 7 & 3299 \\
\hline & 178,9 & 50,0 & 80,45 & 5,2 & 8,6 & 39,3 & 603 & 2099 & 179,2 & 50,0 & & 5,2 & 8,5 & 3 & 656 & 97 & 179,4 & 50,0 & 28 & 5,2 & 8,5 & & 2685 & 2096 & & 0,0 & & 5,2 & 8,4 & 3 & 2695 \\
\hline & 297,1 & 82,7 & 100,00 & 8,7 & 12,8 & & 04 & 00 & 269,4 & 75,0 & 100,00 & 7,9 & 11,3 & 59,2 & 489 & & 43,0 & 67,7 & 100,00 & 7,1 & 10,5 & & 2550 & 2100 & 231,8 & 4,6 & 100,00 & 6,8 & 10,0 & 1,0 & 2606 \\
\hline 03 & 80,7 & 25,0 & 46,50 & 2,4 & 4,3 & 12,7 & 915 & 1502 & 81,7 & 25,0 & 49.57 & 2,4 & 4,3 & $12, \mathrm{~s}$ & 104 & 00 & 81, & 25,0 & 50,46 & 2,4 & 4, & $\overline{12}$ & 3103 & 1503 & 82 & 25,0 & 50,76 & 2,4 & 4,2 & 12,9 & 3122 \\
\hline 2 & 3,7 & 50,0 & 36 & 4,8 & 7,0 & 25,8 & 40 & 507 & 16 & 50,0 & 60,4 & & 6,9 & 25,8 & 84 & 05 & 163,7 & 50,0 & 2,21 & 4,8 & & 25,8 & 2560 & 505 & 16 & 50,0 & & 4,8 & 8 & 7 & 2621 \\
\hline 66 & 295,1 & 90,2 & 100,00 & 8,6 & 11,7 & 46,5 & 341 & 1503 & 237,6 & 72,6 & 100,00 & 6,9 & 9,5 & 37,4 & ,2435 & 504 & 231,7 & 70,8 & 100,00 & 6,8 & 9,5 & 36,5 & 2438 & 1503 & 212,7 & 65,0 & 100,00 & 6,2 &, 7 & 33,5 & ,2527 \\
\hline 01 & 96,8 & 25,0 & 54,95 & 2,8 & 5,3 & 18,3 & 924 & 1793 & 96,8 & 25,0 & 57,12 & 2,8 & 5,2 & 18,2 & 3064 & 303 & 97,1 & 25,0 & 59,20 & 2,8 & 5,3 & 18,3 & 3047 & 1802 & 97,1 & 25,0 & 30 & 2,8 & 2 & 8,3 & 3139 \\
\hline 1796 & 194,3 & 50,0 & 68,17 & 5,7 & 8,5 & 36,5 & 144 & 1799 & 193,3 & 50,0 & 71 & 5,6 & 8,5 & 36,4 & 61 & 33 & 194,1 & 50,0 & 62 & 5,7 & 0,0 & 5,6 & 541 & 97 & 8 & 0,0 & & 5,7 & 6 & 6,5 & 2637 \\
\hline 1795 & 347,5 & 89,6 & 100,00 & 10,1 & 13,7 & 65,3 & 0,2352 & 1802 & 280,9 & 72,5 & 100,00 & 8,2 & 11,7 & 53,0 & 0,2395 & 1798 & 231,6 & 59,7 & 100,00 & 6,8 & 10,0 & 43,6 & 2472 & 1800 & 220,2 & 6,8 & 100,00 & 6,4 & 9,5 & 41,5 & 2550 \\
\hline 2099 & 89,3 & $25, \mathrm{C}$ & 66,55 & 2,6 & 5,6 & 19 & 166 & 2100 & 89 & & 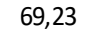 & 2,6 & 5,4 & 19 & 268 & 97 & 90,3 & 25,0 & 67 & 2,6 & 5,4 & & 301 & 2096 & 89 & 5,0 & & 2,6 & 2 & 6 & 3422 \\
\hline 2098 & 179,6 & 50,0 & 78,40 & 5,2 & 8,6 & 39,5 & 1552 & 2099 & 178,9 & 50,0 & 81,68 & 5,2 & 8,3 & 39,3 & 0,2667 & 97 & 179,1 & 50,0 & 82,90 & 5,2 & 8,5 & , 3 & 2671 & 2099 & 179,6 & 0,0 & ,75 & 5,2 & 8,4 & 9,5 & 2752 \\
\hline 94 & 333,7 & 92,9 & 100,00 & 9,7 & 14,0 & 73,2 & 370 & 997 & 270,7 & 75,4 & 100,00 & 7,9 & 11,6 & 595 & 508 & 22 & 243,6 & 67,8 & 100,00 & 7,1 & 10,6 & 3,6 & 2547 & 098 & 228,0 & 3,5 & 100,00 & 6,7 & 9 & 1 & 2660 \\
\hline \multicolumn{8}{|c|}{ AVANÇO $11,5^{\circ}$} & \multicolumn{8}{|c|}{ AVANÇO $12,5^{\circ}$} & \multicolumn{8}{|c|}{ AVANÇO $12,5^{\circ}$} & \multicolumn{8}{|c|}{ AVANÇO $13,5^{\circ}$} \\
\hline 1503 & 82,1 & 25,0 & 47,53 & 2,4 & 4,3 & 12 & 921 & 1505 & 81,6 & 25. & 5067 & 2,4 & 4.3 & 1 & 3066 & 00 & 315 & 25,0 & 51,07 & 2,4 & 4,3 & 12 & 3153 & 503 & 82 & 25,0 & 51,26 & 2,4 & 4,3 & 9 & 3193 \\
\hline 66 & 163,6 & 50,0 & 57 & 4,8 & 6,9 & & 446 & 1505 & 162 & 50 & 6 & 7 & 6 & 25 & 572 & 05 & 163,9 & 50,0 & 84 & 4,8 & 6,8 & 25 & 2613 & 506 & 163,7 & 50,0 & & 4,8 & 8 & 8 & 2688 \\
\hline 1507 & 287,2 & 87,8 & 100,00 & 8,4 & 11,3 & 45,3 & 2384 & 1502 & 233,5 & 71,4 & 100,00 & 6,8 & 9,5 & 36,7 & 0,2351 & 1504 & 231,2 & 70,7 & 100,00 & 6,8 & 9,5 & 36,4 & 0,2456 & 1501 & 206,2 & 63,0 & 100,00 & 6,0 & 8,5 & 32,4 & , 2587 \\
\hline 1794 & 96,6 & 25,0 & 55,75 & 2,8 & 5,2 & 18,1 & 943 & 1800 & 96 , & 25,0 & 58, & 2,8 & - & 18 , & 3037 & 1801 & 97,4 & 25,0 & 59,22 & 2,8 & 5,3 & 18 & 3120 & 1802 & 97 & 25,0 & & 2,8 & 5,1 & 8,3 & 3166 \\
\hline 1802 & 194,4 & 50,0 & 69,60 & 5,7 & 8,4 & 36,7 & 461 & 1794 & 194, & 50,0 & 12,16 & 5,7 & 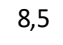 & 36,6 & 530 & 99 & 194,5 & 50,0 & 73,47 & 5,7 & $\infty, 0$ & 36 , & 2596 & 1794 & 193,6 & 50,0 & & 5,1 & 5 & 6,4 & 2655 \\
\hline 1794 & 346,6 & 89,4 & 100,00 & 10,1 & 13,9 & 65,1 & 0,2376 & 1804 & 257,4 & 66,4 & 100,00 & 7,5 & 10,5 & 48,6 & 0,2401 & 1799 & 239,5 & 61,8 & 100,00 & 7,0 & 10,0 & 45,1 & 0,2492 & 1798 & 216,6 & 55,9 & 100,00 & 6,3 & 9,4 & 40,8 & ,2585 \\
\hline 2098 & 89,6 & 25,0 & 67,70 & 2,6 & 5,4 & 19,7 & 3196 & 2099 & 87,9 & 25,0 & 69,67 & 2,6 & 5,4 & 19,3 & 3304 & 100 & 89,7 & 25,0 & 70,86 & 2,6 & 5,4 & 9,7 & 3332 & 2098 & 89,4 & 25,0 & 71,43 & 2,6 & 3 & 9,6 & 3363 \\
\hline 2100 & 179,3 & 50,0 & 79,61 & 5,2 & 8,5 & 39,4 & 2578 & 2098 & 180,2 & 50,0 & 82,19 & 5,3 & 8,5 & 39,6 & 2642 & .00 & 179,4 & 50,0 & 82,99 & 5,2 & 8,5 & 39,4 & 2708 & 2098 & 178,7 & 50,0 & 4,16 & 5,2 & 8,4 & 39,3 & , 2736 \\
\hline
\end{tabular}


F.

Tabelas de Testes com Otimizações para as Misturas DBE

\begin{tabular}{|c|c|c|c|c|c|c|c|c|c|c|c|c|c|c|c|c|c|c|c|c|c|c|}
\hline & 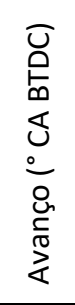 & 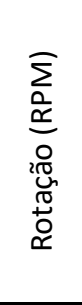 & $\begin{array}{l}\bar{\xi} \\
\Sigma \\
\frac{0}{v} \\
\overline{0} \\
\circ\end{array}$ & 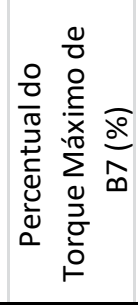 & $\begin{array}{l}\frac{0}{0} \\
\frac{1}{0} \\
\frac{0}{0} \\
\frac{0}{0} \\
\frac{0}{0} \\
\frac{0}{4}\end{array}$ & 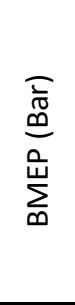 & 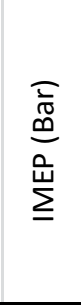 & 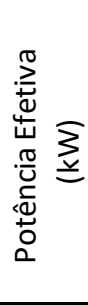 & 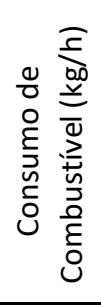 & 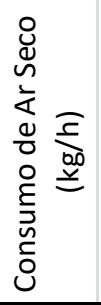 & 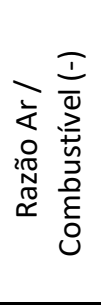 & $\begin{array}{l}\text { I } \\
\frac{\pi}{0} \\
\frac{0}{0} \\
\frac{1}{0} \\
J\end{array}$ & 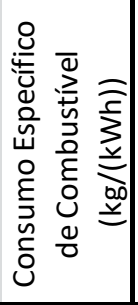 & 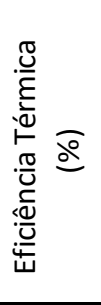 & 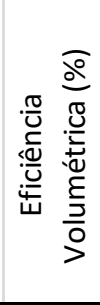 & 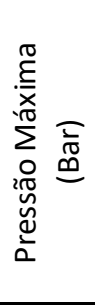 & 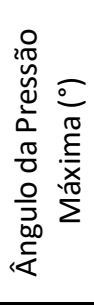 & 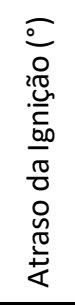 & 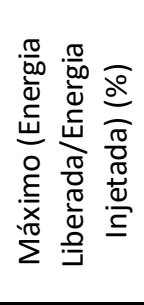 & 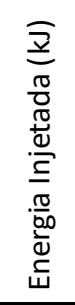 & 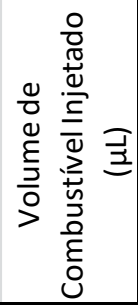 & 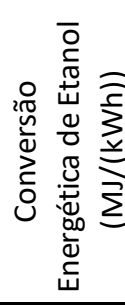 \\
\hline \multirow{9}{*}{ B7 } & \multirow{9}{*}{10,5} & 1501 & 81,2 & 25,0 & 46,6 & 2,4 & 4,2 & 12,8 & 3,7 & 204,9 & 55,5 & 3,85 & 0,2895 & 27,6 & 94,2 & 67,4 & 5,0 & 14,0 & 85,43 & 1,85 & 48,94 & \\
\hline & & 1502 & 161,9 & 50,0 & 56,9 & 4,7 & 6,9 & 25,5 & 6,1 & 221,1 & 36,5 & 2,53 & 0,2378 & 33,5 & 101,7 & 74,5 & 9,3 & 14,0 & 82,91 & 3,05 & 80,63 & \\
\hline & & 1503 & 327,2 & 100,0 & 100,0 & 9,6 & 12,7 & 51,5 & 11,5 & 272,0 & 23,7 & 1,64 & 0,2232 & 35,7 & 124,2 & 98,5 & 13,0 & 12,0 & 81,41 & 5,75 & 151,91 & \\
\hline & & 1804 & 96,5 & 25,0 & 54,6 & 2,8 & 5,3 & 18,2 & 5,2 & 257,8 & 49,8 & 3,45 & 0,2842 & 28,1 & 98,4 & 77,0 & 7,0 & 11,0 & 90,53 & 2,17 & 57,23 & \\
\hline & & 1791 & 193,4 & 50,0 & 67,8 & 5,6 & 8,4 & 36,4 & 8,6 & 295,3 & 34,3 & 2,38 & 0,2368 & 33,7 & 113,2 & 90,1 & 9,0 & 10,7 & 86,02 & 3,61 & 95,33 & \\
\hline & & 1801 & 387,7 & 100,0 & 100,0 & 11,3 & 15,3 & 73,1 & 16,2 & 379,7 & 23,4 & 1,62 & 0,2216 & 36,0 & 145,8 & 121,5 & 13,0 & 8,3 & 87,10 & 6,76 & 178,58 & \\
\hline & & 2098 & 90,0 & 25,0 & 66,6 & 2,6 & 5,4 & 19,8 & 6,2 & 303,4 & 49,3 & 3,42 & 0,3114 & 25,6 & 100,1 & 82,8 & 6,0 & 9,0 & 96,55 & 2,22 & 58,67 & \\
\hline & & 2100 & 180,3 & 50,0 & 78,6 & 5,3 & 8,5 & 39,6 & 9,9 & 351,5 & 35,6 & 2,47 & 0,2488 & 32,1 & 116,0 & 100,1 & 9,0 & 9,3 & 92,64 & 3,55 & 93,59 & \\
\hline & & 2097 & 359,1 & 100,0 & 100,0 & 10,5 & 14,6 & 78,9 & 18,0 & 428,5 & 23,8 & 1,65 & 0,2278 & 35,0 & 142,4 & 130,3 & 10,0 & 5,7 & 87,64 & 6,46 & 170,42 & \\
\hline \multirow{9}{*}{ B15E0 } & \multirow{9}{*}{10,5} & 1502 & 82,1 & 25,0 & 46,5 & 2,4 & 4,3 & 12,9 & 3,7 & 198,6 & 53,0 & 3,72 & 0,2902 & 28,0 & 91,9 & 66,5 & 5,0 & 13,7 & 87,99 & 1,82 & 48,66 & \\
\hline & & 1506 & 163,5 & 50,0 & 57,0 & 4,8 & 6,9 & 25,8 & 6,2 & 217,3 & 35,3 & 2,48 & 0,2388 & 34,0 & 100,5 & 74,6 & 10,0 & 13,7 & 82,85 & 3,05 & 81,33 & \\
\hline & & 1501 & 322,8 & 98,7 & 100,0 & 9,4 & 12,6 & 50,8 & 11,5 & 271,3 & 23,6 & 1,66 & 0,2267 & 35,8 & 123,7 & 100,0 & 13,0 & 13,3 & 82,03 & 5,67 & 151,35 & \\
\hline & & 1796 & 97,2 & 25,0 & 54,6 & 2,8 & 5,3 & 18,3 & 5,4 & 250,8 & 46,7 & 3,28 & 0,2938 & 27,6 & 96,9 & 76,5 & 7,0 & 14,3 & 89,44 & 2,22 & 59,40 & \\
\hline & & 1798 & 194,0 & 50,0 & 67,9 & 5,7 & 8,4 & 36,5 & 8,8 & 287,6 & 32,5 & 2,28 & 0,2420 & 33,5 & 111,0 & 89,8 & 10,0 & 9,7 & 88,51 & 3,62 & 96,69 & \\
\hline & & 1801 & 377,9 & 97,5 & 100,0 & 11,0 & 14,8 & 71,3 & 16,1 & 378,0 & 23,5 & 1,65 & 0,2260 & 35,9 & 144,9 & 121,9 & 13,0 & 7,3 & 84,91 & 6,61 & 176,60 & \\
\hline & & 2100 & 89,9 & 25,0 & 66,9 & 2,6 & 5,4 & 19,8 & 6,3 & 299,1 & 47,3 & 3,32 & 0,3199 & 25,4 & 99,3 & 83,1 & 6,0 & 8,0 & 96,38 & 2,22 & 59,26 & \\
\hline & & 2098 & 180,7 & 50,0 & 78,6 & 5,3 & 8,4 & 39,7 & 10,2 & 346,2 & 34,0 & 2,39 & 0,2566 & 31,9 & 115,1 & 99,9 & 9,0 & 9,0 & 90,07 & 3,60 & 96,04 & \\
\hline & & 2099 & 353,1 & 98,3 & 100,0 & 10,3 & 14,4 & 77,6 & 17,7 & 433,5 & 24,6 & 1,73 & 0,2280 & 35,7 & 143,6 & 130,9 & 10,0 & 6,0 & 88,29 & 6,24 & 166,58 & \\
\hline \multirow{9}{*}{ B15E5 } & \multirow{9}{*}{9,5} & 1503 & 80,7 & 25,0 & 46,50 & 2,4 & 4,3 & 12,7 & 3,7 & 185,8 & 50,2 & 3,59 & 0,2915 & 28,4 & 88,1 & 64,6 & 7,0 & 14,3 & 92,28 & 1,79 & 48,81 & 8,54 \\
\hline & & 1502 & 163,7 & 50,0 & 57,36 & 4,8 & 7,0 & 25,8 & 6,3 & 201,8 & 32,1 & 2,29 & 0,2440 & 33,9 & 95,8 & 71,0 & 12,0 & 14,3 & 86,20 & 3,04 & 82,90 & 9,40 \\
\hline & & 1506 & 295,1 & 90,2 & 100,00 & 8,6 & 11,7 & 46,5 & 10,9 & 240,4 & 22,1 & 1,58 & 0,2341 & 35,3 & 112,1 & 88,2 & 14,7 & 12,0 & 83,42 & 5,25 & 143,43 & 9,55 \\
\hline & & 1801 & 96,8 & 25,0 & 54,95 & 2,8 & 5,3 & 18,3 & 5,3 & 234,3 & 43,9 & 3,14 & 0,2924 & 28,3 & 95,5 & 72,3 & 7,7 & 13,7 & 93,91 & 2,15 & 58,74 & 7,08 \\
\hline & & 1796 & 194,3 & 50,0 & 68,17 & 5,7 & 8,5 & 36,5 & 8,9 & 268,3 & 30,0 & 2,14 & 0,2444 & 33,8 & 106,3 & 85,4 & 11,0 & 12,3 & 88,53 & 3,61 & 98,53 & 7,88 \\
\hline & & 1795 & 347,5 & 89,6 & 100,00 & 10,1 & 13,7 & 65,3 & 15,4 & 324,6 & 21,1 & 1,51 & 0,2352 & 35,1 & 128,3 & 108,2 & 13,3 & 12,0 & 84,40 & 6,23 & 170,01 & 11,52 \\
\hline & & 2099 & 89,3 & 25,0 & 66,55 & 2,6 & 5,6 & 19,6 & 6,2 & 277,7 & 44,7 & 3,19 & 0,3166 & 26,1 & 94,5 & 79,2 & 6,7 & 9,7 & 101,84 & 2,15 & 58,63 & 6,69 \\
\hline & & 2098 & 179,6 & 50,0 & 78,40 & 5,2 & 8,6 & 39,5 & 10,1 & 321,0 & 31,9 & 2,28 & 0,2552 & 32,4 & 109,4 & 94,1 & 10,7 & 8,3 & 96,83 & 3,49 & 95,13 & 6,08 \\
\hline & & 2094 & 333,7 & 92,9 & 100,00 & 9,7 & 14,0 & 73,2 & 17,3 & 397,0 & 22,9 & 1,64 & 0,2370 & 34,9 & 135,3 & 119,4 & 12,0 & 6,3 & 90,03 & 6,00 & 163,72 & 9,56 \\
\hline
\end{tabular}




\begin{tabular}{|c|c|c|c|c|c|c|c|c|c|c|c|c|c|c|c|c|c|c|c|c|c|c|}
\hline 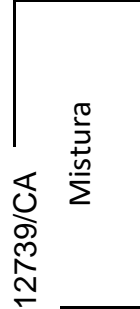 & 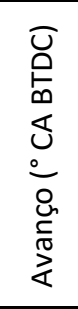 & 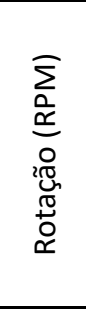 & $\begin{array}{l}\overline{\bar{\varepsilon}} \\
\frac{\sum}{0} \\
\frac{0}{0} \\
\frac{0}{\circ} \\
.\end{array}$ & 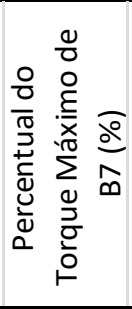 & 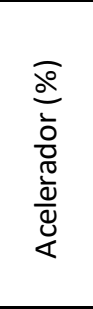 & 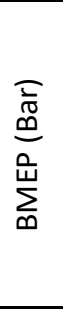 & 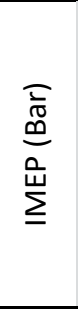 & 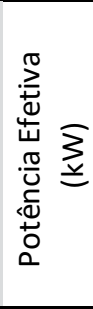 & 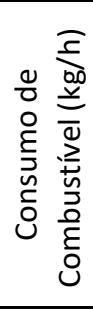 & 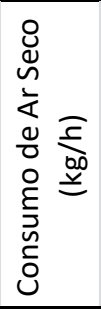 & 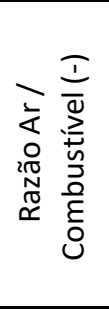 & $\begin{array}{l}I \\
\frac{\pi}{0} \\
\frac{\pi}{0} \\
\frac{E}{J}\end{array}$ & 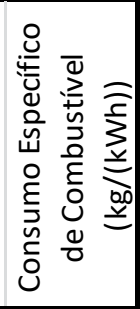 & 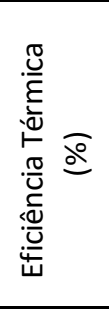 & 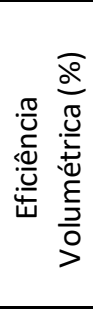 & 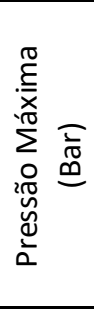 & 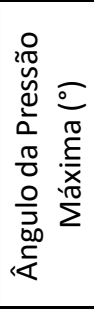 & 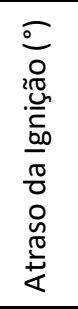 & 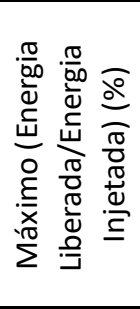 & 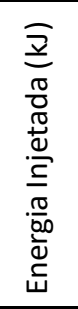 & 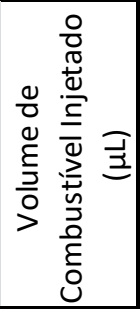 & 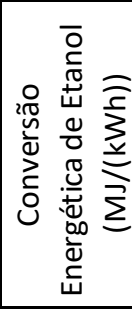 \\
\hline \multirow{9}{*}{$15 \mathrm{E} 10$} & \multirow{9}{*}{10,5} & 1503 & 81,5 & 25,0 & 47,7 & 2,4 & 4,3 & 12,8 & 3,8 & 202,3 & 53,0 & 3,85 & 2976 & 28,3 & 93,8 & 65,4 & 8,3 & 14,7 & 90,71 & 1,80 & 50,26 & 9,91 \\
\hline & & 1504 & 164,8 & 50,0 & 58,2 & 4,8 & 7,0 & 25,9 & 6,5 & 217,1 & 33,4 & 2,43 & 2509 & 33,6 & 100,8 & 73,3 & 9,0 & 12,7 & 83,56 & 3,08 & 85,91 & 9,88 \\
\hline & & 1503 & 231,8 & 70,8 & 100,0 & 6,8 & 9,5 & 36,5 & 9,0 & 222,1 & 24,7 & 80 & 2457 & 34,1 & 104,1 & 81,1 & 14,0 & 13,3 & 81,97 & 4,27 & 119,03 & 11,03 \\
\hline & & 1798 & 96,6 & 25,0 & 55,5 & 2,8 & 5,3 & 18,2 & 5,4 & 248,7 & 46,0 & 3,34 & 2972 & 28,3 & 96,5 & 75,7 & 5,0 & 15,0 & 3,72 & 2,14 & 59,70 & 8,86 \\
\hline & & 1796 & 193,9 & 50,0 & 68,9 & 5,7 & 8,4 & 36,5 & 9,2 & 284,4 & 30,9 & 2,25 & 2527 & 33,3 & 110,2 & 88,0 & 11,0 & 10,7 & 9,10 & 3,63 & 101,38 & 9,57 \\
\hline & & 1794 & 250,9 & 64,7 & 100,0 & 7,3 & 10,1 & 46,9 & 11,8 & 296,7 & 25,2 & 1,83 & 0,2514 & 33,5 & 117 & 92,1 & 13,0 & 11,0 & 88,86 & 4,68 & 130,75 & 12,38 \\
\hline & & 2097 & 90,1 & 25,0 & 67,1 & 2,6 & 5,3 & 19,8 & 6,3 & 294,6 & 46,8 & 3,40 & 3178 & 26,5 & 98,3 & 82,5 & 7,0 & 90 & 98,20 & 2,14 & 59,72 & 7,99 \\
\hline & & 2097 & 178,8 & 50,0 & 79,1 & 5,2 & 8,5 & 39,3 & 10,1 & 340,4 & 33,6 & 44 & 583 & 32,6 & 113,8 & 98,7 & 10,0 & & & 43 & 95,74 & 7,38 \\
\hline & & 2101 & 257,3 & 71,7 & 100,0 & 7,5 & 11,0 & 56,6 & 14,2 & 377,1 & 26,5 & 1,93 & 2510 & 33,5 & 127,5 & 105,3 & 11,0 & 7,0 & 7,97 & 4,81 & 134,35 & 9,86 \\
\hline \multirow{9}{*}{ B15E15 } & \multirow{9}{*}{11,5} & 500 & 81,5 & 25,0 & 50,5 & 2,4 & 4,3 & 12,8 & 4,0 & 204,4 & 51,4 & 3,80 & 3103 & 27,7 & 94,7 & 66,9 & 7,0 & 16,7 & 7,77 & 85 & 52,83 & 11,62 \\
\hline & & 05 & 163,7 & 50,0 & 62,2 & 4,8 & 6,8 & 25,8 & 6,6 & 216,9 & 32,8 & 2,43 & 2560 & 33,6 & 100,3 & 73,2 & 10,0 & 16,0 & 36 & 3,06 & 87,50 & 9,69 \\
\hline & & 1504 & 231,7 & 70,8 & 100,0 & 6,8 & 9,5 & 36,5 & 8,9 & 237,7 & 26,7 & 1,98 & 0,2438 & 35,2 & 109,4 & 84,6 & 11,7 & 15,7 & 1,24 & 4,13 & 118,00 & 9,03 \\
\hline & & 1803 & 97,1 & 25,0 & 59,2 & 2,8 & 5,3 & 18,3 & 5,6 & 250,3 & 44,8 & 3,32 & 0,3047 & 28,2 & 96,8 & 76,9 & 5,0 & 14,3 & 02 & 2,16 & 61,76 & 9,96 \\
\hline & & 1803 & 194,1 & 50,0 & 73,6 & 5,7 & 8,6 & 36,6 & 9,3 & 286,2 & 30,7 & 2,27 & 2541 & 33,8 & 110,5 & 90,1 & 11,0 & 13,3 & 1,83 & 3,61 & 102,97 & 3,80 \\
\hline & & 1798 & 231,6 & 59,7 & 100,0 & 6,8 & 10,0 & 43,6 & 10,8 & 310,5 & 28,8 & 2,13 & 0,2472 & 34,8 & 119,8 & 94,0 & 13,0 & 12,7 & 34,71 & 4,20 & 119,78 & 9,00 \\
\hline & & 2097 & 90,3 & 25,0 & 70,7 & 2,6 & 5,4 & 19,8 & 6,5 & 299,5 & 45,8 & 3,39 & 0,3301 & 26,0 & 99,6 & 83,2 & 4,0 & 11,7 & 98,99 & 2,18 & 62,25 & 10,53 \\
\hline & & 2097 & 179,1 & 50,0 & 82,9 & 5,2 & 8,5 & 39,3 & 10,5 & 349,2 & 33,2 & 2,46 & 2671 & 32,2 & 116,1 & 99,1 & 10,0 & 9,7 & 3,00 &, 50 & 99,95 & 8,89 \\
\hline & & 2102 & 243,6 & 67,8 & 100,0 & 7,1 & 10,6 & 53,6 & 13,7 & 394,3 & 28,9 & 2,14 & 0,2547 & 33,7 & 130,6 & 106,3 & 11,0 & 11,3 & 37,89 & 4,55 & 129,96 & 9,12 \\
\hline \multirow{9}{*}{ B15E20 } & \multirow{9}{*}{11,5} & 1503 & 82,1 & 25,0 & 50,2 & 2,4 & 4,3 & 12,9 & 4,0 & 206,8 & 51,3 & 3,87 & 0,3118 & 28,1 & 95,3 & 67,2 & 8,0 & 17,3 & 89,89 & 1,83 & 53,61 & 10,87 \\
\hline & & 1505 & 163,6 & 50,0 & 62,2 & 4,8 & 6,8 & 25,8 & 6,7 & 219,3 & 32,6 & 2,46 & 2611 & 33,6 & 100,8 & 73,4 & 9,0 & 18,0 & 3,08 & 3,06 & 89,49 & 9,59 \\
\hline & & 1499 & 213,7 & 65,3 & 100,0 & 6,2 & 8,8 & 33,5 & 8,4 & 235,6 & 28,2 & 2,13 & 0,2491 & 35,2 & 108,3 & 79,1 & 11,3 & 16,0 & 0,85 & 3,84 & 112,09 & 8,94 \\
\hline & & 1794 & 96,9 & 25,0 & 58,0 & 2,8 & 5,2 & 18,2 & 5,6 & 253,8 & 45,3 & 3,42 & 0,3079 & 28,5 & 98,0 & 77,8 & 6,0 & 14,7 & 90,74 & 2,14 & 62,48 & 9,90 \\
\hline & & 1796 & 194,0 & 50,0 & 73,2 & 5,7 & 8,6 & 36,5 & 9,4 & 291,6 & 31,1 & 2,35 & 0,2569 & 34,1 & 112,3 & 87,9 & 12,0 & 12,7 & 91,38 & 3,57 & 104,39 & 8,62 \\
\hline & & 1797 & 219,3 & 56,6 & 100,0 & 6,4 & 9,5 & 41,3 & 10,4 & 306,7 & 29,4 & 2,22 & 0,2527 & 34,7 & 117,9 & 90,7 & 12,3 & 14,3 & 88,94 & 3,96 & 115,77 & 8,80 \\
\hline & & 2099 & 89,4 & 25,0 & 70,3 & 2,6 & 5,2 & 19 & 6,7 & & 46,7 & 3,5 & 3299 & 26,3 & 100,3 & 83, & 5,0 & 13,0 & 55 & 17 & 63,42 & 10,01 \\
\hline & & (960 & 178,9 & 50,0 & 82,7 & 5,2 & 8,4 & 39,3 & 10,6 & & כונסנ & & 2695 & 3,3 & 117,1 & 98,0 & 8,0 & 11,3 & & 3,40 & 01,03 & 8,73 \\
\hline & & 100 & 31,8 & 4,6 & 100,0 & 6,8 & 10,0 & 51,0 & 13,3 & 394,1 & 29,7 & 2,24 & 0,2606 & 33,6 & 129,9 & 100,3 & 12,0 & 11,7 & 86,88 & 4,34 & 126,69 & 9,09 \\
\hline
\end{tabular}

